JOÃO PEDRO DE CASTRO NUNES PEREIRA

A CONCENTRAÇÃO GEOGRÁFICA DE EMPRESAS NO AGRONEGÓCIO DE FLORES: UMA ANÁLISE DAS LOCALIDADES DE HOLAMBRA E MOGI DAS CRUZES 
JOÃO PEDRO DE CASTRO NUNES PEREIRA

\section{A CONCENTRAÇÃO GEOGRÁFICA DE EMPRESAS AGRONEGÓCIO DE FLORES: UMA ANÁLISE DAS LOCALIDADES DE HOLAMBRA E MOGI DAS CRUZES}

Tese apresentada à Escola

Politécnica da Universidade de São

Paulo para obtenção do título de

Doutor em Engenharia.

Área de concentração:

Engenharia de Produção

Orientador: Prof ${ }^{a}$ Livre-Docente

Marly Monteiro de Carvalho

São Paulo

2007 


\section{FICHA CATALOGRÁFICA}

Pereira, João Pedro de Castro Nunes.

A concentração geográfica de empresas do agronegócio de flores: uma análise das localidades de Holambra e Mogi das Cruzes / J.P. de C.N. Pereira. -- São Paulo, 2007. 244 p.

Tese (Doutorado) - Escola Politécnica da Universidade de São Paulo. Departamento de Engenharia de Produção.

1.Estratégia empresarial 2.Clusters 3.Produção de flores 4.Agronegócio I.Universidade de São Paulo. Escola Politécnica. Departamento de Engenharia de Produção Il.t. 


\section{DEDICATÓRIAS}

Para a Chris, meu maior incentivo para que tudo isso acontecesse e uma parceira incansável em todas as etapas deste trabalho 
A minha Mãe, minha madrinha Didi e ao men mais que tio Koká, pelo apoio e incentivo deste os primeiros passos desta jornada. 
Ao meu Pai, meus avós Hugo e

Lais e a querida Tivó, sempre com muitas saudades ....

(In Memorian) 
Ao amigo Cláudio Solis, pessoa fundamental para que elpudesse iniciar este trabalho

(In Memorian) 


\section{AGRADECIMENTOS}

A Professora Marly Monteiro de Carvalho meu agradecimento muito especial. Obrigado pela dedicação e apoio que me deu nesse período em que realizamos este trabalho.

Ao grande amigo e meu guru, professor Daniel Augusto Moreira, pelo incentivo e apoio fundamental para que eu fizesse esse trabalho. Ao Professor Daniel, também um agradecimento muito especial.

Aos meus irmãos e irmãs, meus sobrinhos e sobrinhas, por sempre me apoiarem e pela paciência em aturar este Ser cada vez mais ranzinza, enquanto este trabalho não terminava!

A Família Teruya pelo apoio e pela disponibilidade constante em estar sempre me ajudando naquilo que eu necessitasse!

Ao Sr. João e ao Sr. Pedreira, verdadeiros amigo em todas as horas e mestres na solução de problemas e orientações! Vocês foram fundamentais para que eu pudesse terminar esse trabalho! Obrigado sempre!

Ao Dr. Wilson Simonelli, que neste período todo (e sempre) cuidou de minha saúde física e mental, e garantiu que pudesse alguns momentos que eu vivi quando fazia este trabalho!

Ao Ailton, a Luiza e a Cidinha, pelos conselhos, incentivos e especialmente pelo carinho, com que sempre me ajudaram nos momentos mais difíceis deste trabalho.

A Professora Marly Cavalcanti, que muito me ajudou neste período, me incentivando sempre a publicar, publicar e publicar!

Aos Professores Fernando Barbin e Renato Garcia pelo apoio durante o período em que passei no Departamento. 
A Professora Rosana Lucille, por ter me apresentado a Professora Marly Cavalcanti e por ter me levado a conhecer Holambra para que eu pudesse realizar esse trabalho.

Ao Professor Batalha, pela ajuda, dicas opiniões que muito contribuíram para o resultado final deste trabalho.

A Roberta e a ao Andia pelo apoio que me deram neste período em que convivemos juntos

A Lídia e a Priscila, pessoas fundamentais para que eu conseguisse terminar tudo isso! Obrigado pelo apoio e pela força que recebi de vocês!

Ao pessoal de Holambra, especialmente a Josi, a Célia, a Suzana, ao Renato e a Cássia, por abrirem as portas mais difíceis naquela cidade, sempre me ajudando como se o trabalho fosse de vocês. Tenham certeza de que este trabalho também é um pouco de vocês.

A Rosana e ao Nelson, colegas de profissão e peças fundamentais para que eu conseguisse trabalhar em Mogi das Cruzes.

A colega Anita Gutierrez pelas orientações e dicas para que eu pudesse melhorar os questionários aplicados.

A amiga Malu pela força, sobretudo na etapa final deste trabalho.

Maria José, Adnéia, Mônica, Luis, Adilson, Cláudio e Regina que com suas luzes ajudaram a iluminar os caminhos mais escuros desta jornada. 



\section{RESUMO}

Este trabalho traz como objeto o fenômeno da concentração geográfica e setorial de empresas, cuja importância na criação de vantagens competitivas para as empresas e para o desenvolvimento regional tem sido estudada e relatada na literatura. Considerando-se a importância dos agronegócios no contexto socioeconômico nacional, associado à importância crescente da floricultura neste setor e a lacuna na literatura no que concerne a esse tipo de arranjo empresarial no contexto dos agronegócios, optou-se pelo desenvolvimento deste estudo em duas localidades paulistas caracterizadas pela concentração de empresas relacionadas aos agronegócios de flores e plantas: Holambra e Mogi das Cruzes. Os principais objetivos desta tese são: elaborar uma estrutura (framework) teórico-conceitual para estudos das concentrações geográficas de empresas do agronegócio de flores e plantas ornamentais; identificar os principais fatores indutores para o estabelecimento de ações conjuntas entre os atores da cadeia e identificar os principais fatores indutores da inovação e da formação das competências coletivas locais.

Dada a complexidade do fenômeno estudado, optou-se por mesclar estratégias de pesquisa de caráter qualitativo e quantitativo (survey). Os principais resultados encontrados mostram: a adequação da estrutura de análise proposta; a influencia do fator étnico nas questões relativas a cooperação para a construção das vantagens competitivas locais; que as ações cooperativas entre os atores da localidade não dependeram de uma ação coordenadora do poder público; que as concentrações geográficas estudadas criam condições para promover maior número de ações conjuntas entre os produtores rurais; que essas ações conjuntas são catalizadas pelas associações de produtores rurais e pelas cooperativas.

Palavras-chave: Estratégia competitiva; Clusters; Produção de flores; Agronegócio 


\begin{abstract}
This thesis aims to understand the phenomenon of geographical and sectional concentration of companies (clusters), whose importance in the creation of competitive advantages and also in the regional development have been studied and reported in specialized literature. Considering the importance of agribusiness in the Brazilian social-economic context and the lack of academic studies concerning with, agribusiness clusters, the present research was performed in two localities of State of São Paulo: Holambra and Mogi das Cruzes, both characterized by the flowers and ornamental plants agribusiness concentration. The main objectives of this thesis are the following: elaborate a theoretic-conceptual structure for flowers agribusiness cluster; identify the main inductive factors inducing for the establishment joint action between the actors of the productive chain; and, verify the inductive factors in innovation and in local collective competences building.

Due to the complexity of the studied phenomenon, the field research design encompasses both qualitative and quantitative (survey) approaches. The main results founded show that: the adequacy of the framework analysis proposed; the ethnic factor influences in the cooperation and local competitive advantages building related issues; the joint actions among the actors of the locality, specially agricultural producers, did not depended on the public power coordination; the studied geographical cluster allows to increase joint actions, specifically among the agricultural producers, stimulated by the agricultural producers associations and by the cooperative societies.
\end{abstract}

Keywords: Competitive Strategy; Clusters; Flower Production; Agribusiness 


\section{LISTA DE TABELAS}

Tabela 6.1. Classificação dos resultados da análise discriminante em função a etnia nas duas localidades estudadas

Tabela 6.2. Relação entre os grupos e fatores relacionados às percepções dos entrevistados 


\section{LISTA DE QUADROS}

Quadro 2.1 Categorias de ações pública - privadas e níveis de governança local-global das atividades econômicas

Quadro 2.2 Tipos de governança identificados por diferentes autores ..... 66

Quadro 2.3 Autores considerados no desenvolvimento da estrutura analítica proposta

Quadro 3.1 Principais características e correspondências entre as estratégias de pesquisa e os tipos de questões levantadas .. 71

Quadro 3.2 Relação entre as Questões e Proposições elaboradas no presente estudo ............................................................. 76

Quadro 3.3 Composição da amostra da pesquisa qualitativa ................... 79

Quadro 5.1 Composição da amostra: Holambra .................................. 102

Quadro 5.2. Caracterização geral das empresas participantes da pesquisa qualitativa........................................................ 123

Quadro 5.3 Composição da amostra: Mogi das Cruzes ........................ 132

Quadro 5.4 Composição da amostra dos Atores Externos entrevistados 145

Quadro 6.1 Distribuição das Unidades de Produção nos municípios componentes das duas localidades estudadas .

Quadro 6.2 Questões relacionadas à investigação dos fatores associados ao desenvolvimento das ações de parcerias dos produtores rurais das localidades estudadas

Quadro 6.3 Questões relacionadas à investigação dos fatores associados à localidade

Quadro 6.4 Questões relacionadas à investigação dos fatores relacionados ao o papel das entidades cooperativas e associativistas.

Quadro 6.5 Composição dos Fatores em função das questões consideradas na análise fatorial 


\section{LISTA DE GRÁFICOS}

Gráfico 6.1. Distribuição proporcional dos principais grupos étnicos do universo de produtores rurais entrevistados nas duas localidades.

Gráfico 6.2. Distribuição proporcional dos produtores em função do ano de início nas atividades agrícolas de produção de flores e plantas ornamentais ..

Gráfico 6.3. Distribuição proporcional dos produtores em função da origem étnica e as principais origens do conhecimento técnico necessário para 0 desenvolvimento dos negócios

Gráfico 6.4. Freqüência das ações conjuntas entre os produtores rurais

Gráfico 6.5. Motivos indutores para a realização de ações conjuntas entre os produtores rurais nas localidades de Mogi Mirim e Holambra

Gráfico 6.6. Média dos valores de concordância com as questões relativas às atividades de parcerias dos produtores rurais das localidades estudadas

Gráfico 6.7. Média dos valores de concordância com as questões relativas às atividades de parcerias dos produtores rurais das localidades de Holambra e Mogi das Cruzes, analisadas em separado

Gráfico 6.8. Média dos valores de concordância com as questões relativas à percepção do papel da localidade na construção das vantagens competitivas dos negócios de flores e plantas ornamentais das localidades estudadas -análise conjunta

Gráfico 6.9. Média dos valores de concordância com as questões relativas à percepção do papel da localidade na construção das vantagens competitivas dos negócios de flores e plantas ornamentais das localidades de Holambra e Mogi das Cruzes - analise separada ........

Gráfico 6.10. Média dos valores de concordância com as questões relativas à percepção do papel das entidades associativistas e cooperativistas na construção das vantagens competitivas dos negócios de flores e plantas ornamentais das localidades estudadas

Gráfico 6.11. Média dos valores de concordância com as questões relativas à percepção do papel das entidades associativistas e cooperativistas na construção das vantagens competitivas dos negócios de flores e plantas ornamentais em cada uma das localidades estudadas

. Média dos valores de concordância com as questões relativas à percepção do papel da origem étnica no estabelecimento de ações conjuntas pelos produtores das duas localidades 


\section{LISTA DE FIGURAS}

Figura 4.1. Distribuição Geográfica da Área de Floricultura, Estado de São Paulo, 1995-96.

Figura 6.1. Representação gráfica do comportamento de resposta dos questionários em função do caráter étnico dos produtores 


\section{LISTA DE ABREVIATURAS E SÍMBOLOS}

AAFAN - Associação de Agricultores Familiares de Artur Nogueira.

AAFHOL - Associação de Agricultores Familiares de Holambra

ABAFEP - Associação Brasileira do Agronegócio de Flores e Plantas

ACE - Associação Comercial e Empresarial

AFLORD - Associação dos Floricultores da Região da Via Dutra

AGRIFAM - Feira da Agricultura Familiar e do Trabalho Rural

APEX - Agência de Promoção de Exportações

BNDES - Banco Nacional de Desenvolvimento Econômico e Social

CAC - Cooperativa Agrícola de Cotia

CAPH - Cooperativa Agropecuária de Holambra

CATI - Coordenadoria de Assistência Técnica Integral

CEAGESP - Companhia de Entrepostos e Armazéns Gerais de São Paulo IBRAFLOR - Instituto Brasileiro de Floricultura

$\mathrm{CPH}$ - Cooperativa Pecuária Holambra

CVH - Cooperativa Veiling de Holambra

EMBRAPA - Empresa Brasileira de Pesquisa Agropecuária

ENFLOR - Feira de flores, plantas e acessórios, voltada para os floristas

TREKKER TREK - Tradicional corrida holandesa de resistência de tratores

ZESKAMP - Evento esportivo que reúne colônias holandesas de todo o Brasil

ENFLOR - Encontro Nacional de Floristas, Atacadistas, Produtores e Empresas de Acessórios

EXPOAFLORD - Festa das flores de Arujá

EXPOFLORA - Festa das flores de Holambra

FAPESP - Fundação de Amparo à Pesquisa do Estado de São Paulo

FGV-SP - Fundação Getúlio Vargas

GEPAI - Grupo de Pesquisas Agroindustriais 
GTA - Grupo Técnico AFLORD

HORTITEC - Feira de insumos e equipamentos para a agricultura

IAC -Instituto Agronômico de Campinas

IAPAR - Instituto Agronômico do Paraná

IBGE - Instituto Brasileiro de Geografia e Estatística

IBRAFLOR - Instituto Brasileiro de Floricultura

ICMS - Imposto sobre Circulação de Mercadorias e Prestação de Serviços

IDH - Índice de Desenvolvimento Humano

IEA - Instituto de Economia Agrícola

IPEA - Instituto de Pesquisa Econômica Aplicada

Mercaflor -SC - Mercado do Profissional da Floricultura e do Paisagismo

NAFTA - North America Free Trade Agreement

RBB - Empresa de Feiras e Eventos na área de plantas ornamentais

SAI - Sistema Agroindustrial Integrado

SCAIH - Cooperativa de Insumos sediado no município de Holambra

SEADE - Fundação Sistema Estadual de Análise de Dados

SEBRAE - Serviço Brasileiro de Apoio às Micro e Pequenas Empresas,

SENAI - Serviço Nacional de Aprendizagem Industrial

SENAR - Serviço de Aprendizado Rural

SPFLORES - Cooperativa Agrícola Flores de São Paulo

UFSCAR - Universidade Federal de São Carlos 


\section{SUMÁRIO}

CAPÍTULO1 . INTRODUÇÃO ............................................................. 23

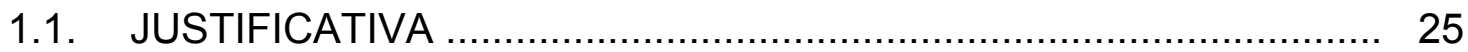

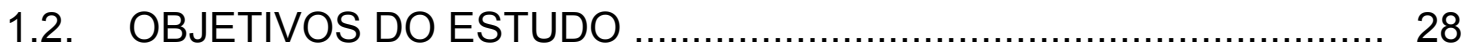

1.3. ESTRUTURA DO TRABALHO …………........................... 29

CAPÍTULO 2. ARCABOUÇO TEÓRICO ............................................... 31

2.1. CONCENTRAÇÃO GEOGRÁFICA E SETORIAL DE EMPRESAS ...... 31

2.1.1. Abordagem Contextual .................................................... 31

2.1.2. Abordagem Teórica ......................................................... 36

2.1.2.1 Distritos Industriais .................................................. 37

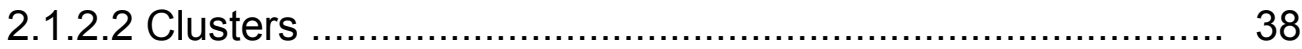

2.1.3 A Inovação no Contexto das Concentrações Geográficas de Empresas

2.1.4 Ações Conjuntas e Eficiência Coletiva como fatores essenciais para análise estratégia das Concentrações Geográficas de Empresas

2.1.5 O Contexto Socioeconômico das Concentrações Geográficas de Empresas: a Relação com as Redes Locais (sociais e empresariais) na Geração das Vantagens Competitivas da Localização

2.2. AGRONEGÓCIO: CONCEITO E PRINCIPAIS ABORDAGENS .......... 48

2.3.ESTRATÉGIA COMPETITIVA .................................................... 52

2.3.1. Estratégia no Contexto Empresarial ................................... 52

2.3.2. Competitividade ............................................................. 56

2.3.3. Análise Ambiental no Contexto da Estratégia Empresarial .... 59

2.3.3.1 Análise do Ambiente Externo ......................................... 59

2.3.3.2 Análise do Ambiente Interno ............................................ 61

2.4. CADEIA DE VALOR E GOVERNANÇA 62

2.4.1. Cadeia de Valor e Sistema de Valor .................................... 63

2.4.2. Governança ....................................................................... 64

2.5. CONCLUSÃO: ESTRUTURA ANALÍTICA ......................................... 66

CAPÍTULO 3. ABORDAGEM METODOLÓGICA ….................................. 70

3.1. CARACTERIZAÇÃO DO PROBLEMA …......................................... 70

3.2. TIPO DE PESQUISA …............................................................ 70

3.3. O PROJETO DE PESQUISA ……........................................... 72 
3.3.1 Levantamento de Dados Secundários …............................... 73

3.3.2 Procedimentos da Pesquisa Qualitativa ............................... 73

3.3.2.1. Questões Específicas e Proposições do Estudo .............. 74

3.3.2.2. Instrumento e Critérios para Seleção dos Entrevistados .. 76

3.3.3 Pesquisa Quantitativa: levantamento do tipo survey ............. 80

3.4. O RECORTE DA PESQUISA (LIMITAÇÕES) ................................. 82

CAPÍTULO 4. O AMBIENTE DE ESTUDO ............................................. 83

4.1. O AGRONEGÓCIO BRASILEIRO DE FLORES ............................... 83

4.2. O AGRONEGÓCIO PAULISTA DE FLORES .................................. 87

4.3. A LOCALIDADE DE HOLAMBRA .................................................. 90

4.3.1. O município de Holambra .................................................. 93

4.3.2. A Influência da Cooperativa Agropecuária de Holambra nos Agronegócios do município …............................................ 96

4.4. A LOCALIDADE DE MOGI DAS CRUZES …................................ 98

4.4.1 O Município de Mogi das Cruzes ........................................ 99

CAPÍTULO 5. RESULTADOS DA PESQUISA QUALITATIVA .................. 101

5.1. ESTUDO DE CAMPO NA LOCALIDADE DE HOLAMBRA ................. 102

5.1.1 Associações de Produtores Rurais ....................................... 103

5.1.1.1 Bloco 1 - Caracterização Geral .................................... 104

5.1.1.2 Bloco 2 - Cooperação e Parceria ................................... 104

5.1.1.3 Bloco 3 - Localidade .................................................. 105

5.1.1.4 Bloco 4 - Inovação e Informações .................................. 108

5.1.1.5 Bloco 5 - Gestão e Estratégias .................................... 109

5.1.2 Entidades de Apoio ........................................................ 110

5.1.2.1 Bloco 1 - Caracterização Geral ..................................... 111

5.1.2.2 Bloco 2 - Cooperação e Parceria ................................... 111

5.1.2.3 Bloco 3 - Localidade ................................................. 112

5.1.2.4 Bloco 4 - Inovação e Informações ................................... 113

5.1.2.5 Bloco 5 - Gestão e Estratégias ……………................ 114

5.1.3 Cooperativa ................................................................ 115

5.1.3.1 Bloco 1 - Caracterização Geral ...................................... 115

5.1.3.2 Bloco 2 - Cooperação e Parceria .................................... 117

5.1.3.3 Bloco 3 - Localidade ................................................... 118 
5.1.3.4 Bloco 4 - Inovação e Informações ................................... 120

5.1.3.5 Bloco 5 - Gestão e Estratégias …………………....... 121

5.1.4 Empresas Meio ........................................................ 123

5.1.4.1 Bloco 1 - Caracterização Geral ..................................... 123

5.1.4.2 Bloco 2 - Cooperação e Parceria .................................... 124

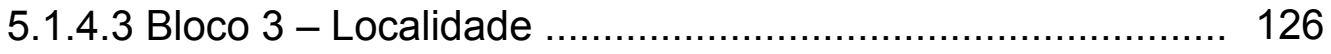

5.1.4. Bloco 4 - Inovação e Informações ..................................... 128

5.1.4.5 Bloco 5 - Gestão e Estratégias ……………............ 128

5. 2. ESTUDO DE CAMPO NA LOCALIDADE DE MOGI DAS CRUZES..... 132

5.2.1 Associações de Produtores Rurais ........................................ 133

5.2.1.1 Bloco 1 - Caracterização Geral ..................................... 134

5.2.1.2 Bloco 2 - Cooperação e Parceria .................................... 135

5.2.1.3 Bloco 3 - Localidade ................................................ 136

5.2.1.4 Bloco 4 - Inovação e Informações ................................. 138

5.2.1.5 Bloco 5 - Gestão e Estratégias …………………........ 138

5.2.2 Entidades de Apoio .................................................... 140

5.2.2.1 Bloco 1 - Caracterização Geral ....................................... 141

5.2.2.2 Bloco 2 - Cooperação e Parceria ..................................... 141

5.2.2.3 Bloco 3 - Localidade .................................................. 142

5.2.4.4 Bloco 4 - Inovação e Informações ................................... 144

5.2.2.5 Bloco 5 - Gestão e Estratégias ………………............... 144

5.3 ENTREVISTA COM ATORES DE FORA DAS LOCALIDADES ESTUDADAS . 144

5.3.1. Câmara Setorial de Flores e Plantas Ornamentais ................. 146

5.3.2 Companhia de Entrepostos e Armazéns Gerais de São Paulo - CEAGESP

5.4 ANÁLISE GLOBAL DOS RESULTADOS QUALITATIVOS ................. 149

5.4.1. Considerações sobre a Proposição 1 .................................... 150

5.4.2. Considerações sobre a Proposição 2 …………………....... 152

5.4.3. Considerações sobre a Proposição 3 …………………....... 154

5.4.4. Considerações sobre a Proposição 4 ....................................... 156

CAPÍTULO 6. RESULTADOS DA PESQUISA QUANTITATIVA ............... 158

6.1. CARACTERIZAÇÃO GERAL DA AMOSTRA .................................. 158

6.2. RESULTADOS DA PESQUISA QUANTITATIVA ............................. 162

6.2.1 Bloco 2 - Parceria e Ação Conjunta ...................................... 162 
6.2.2 Bloco 3 - Localidade ........................................................... 168

6.2.3. Bloco 4 - Cooperativismo e Associativismo ............................ 171

6.3. REFINAMENTO DA ANÁLISE DOS RESULTADOS ......................... 174

6.3.1 Análise Discriminante ........................................................ 174

6.3.2 Análise Fatorial e de Agrupamentos......................................... 176

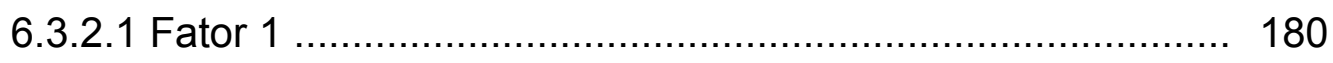

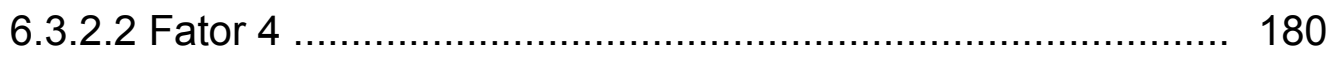

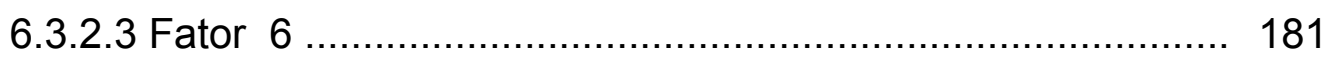

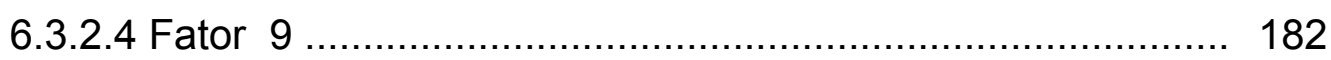

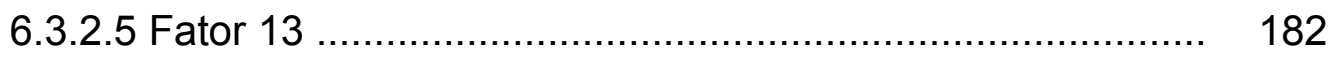

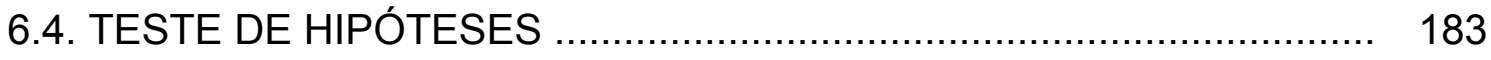

6.4.1 Validade da Hipótese 1 .................................................... 183

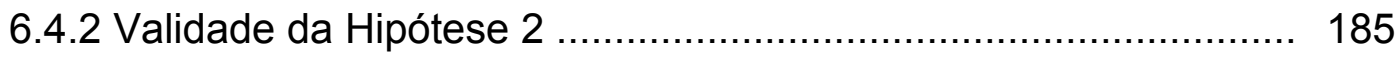

6.4.3 Validade da Hipótese 3 ..................................................... 186

6.4.4 Validade da Hipótese 4 .................................................... 187

6.5. ANÁLISE GLOBAL DOS RESULTADOS QUANTITATIVOS .............. 188

7. CONCLUSÕES E RECOMENDAÇÕES ……...................................... 189

7.1. RECOMENDAÇÕES E RESTRIÇÕES DA PESQUISA ....................... 193

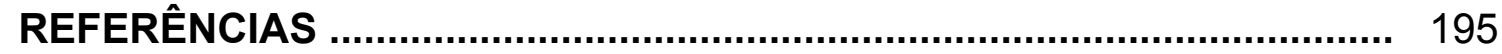

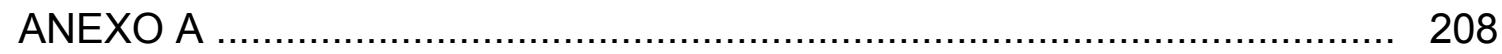

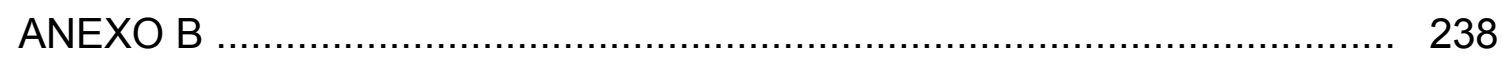




\section{CAPÍTULO 1. INTRODUÇÃO}

O presente trabalho traz como objeto o fenômeno da concentração geográfica de empresas e busca compreender seu impacto na obtenção de vantagens competitivas da localidade e ao conjunto das empresas nela inseridas.

A partir do final da década de 1980 consolidava-se o caráter globalizado da economia mundial marcada por uma dinâmica de transformação tecnológica muito intensa, que trouxe reflexos imediatos nos aspectos relativos à comercialização e à gestão dos negócios.

Diversos trabalhos na literatura mostram que o desenvolvimento das organizações produtivas nesse final de século fora caracterizado pela busca permanente da adequação a esse novo cenário onde um novo padrão de bens e serviços começava a emergir. Para sobreviverem, essas organizações necessitavam se adequar às novas regras, agora fundamentadas na de flexibilidade e na agilidade. Para tanto, modificações profundas nas estruturas organizacionais e nos relacionamentos intra e inter organizações tornaram-se imprescindíveis.

Os estudos relacionados a esse novo cenário competitivo encontram sua fundamentação teórica nos temas relativos aos aspectos intrínsecos das organizações e seu relacionamento com a localidade a qual se encontra inserida. Segundo Humprhey e Schmitz (2000) esses estudos podem ser vistos sob o enfoque das seguintes áreas do conhecimento humano: nova geografia econômica, estudos referentes ao desenvolvimento local e/ou regional; gestão estratégica de negócios e inovação tecnológica.

Os trabalhos sobre as concentrações geográficas de empresas fazem parte do cenário acadêmico há tempos, desde os primeiros estudos sobre distritos industriais, realizados por Marshall na década de 1920 (IGLIORI, 2000). A partir de então, várias denominações como clusters, aglomerações industriais, sistemas produtivos locais ou sistemas locais de produção, arranjos produtivos locais, dentre outros, são comumente observados na literatura, com nuances de semântica distintas. Sendo assim, nesta tese este fenômeno será denominado "concentração geográfica de empresas", dado que se utilizará elementos de diferentes disciplinas no quadro teórico-conceitual, sendo necessário homogeneizar as nomenclaturas. 
Independentemente da forma como esse tipo de organização empresarial tenha sido caracterizado, estudos têm mostrado que a concentração geográfica de empresas apresenta um papel de destaque no desenvolvimento econômico de vários países. De maneira geral, esses estudos buscavam compreender a influencia desse tipo de organização empresarial na dinâmica das relações capazes de gerar externalidades responsáveis pelo sucesso competitivo da localidade e suas organizações.

A se considerar o Brasil, um País fundamentalmente baseado no desempenho de suas atividades agroindústrias, vê-se nos estudos dos agrupamentos relacionados aos agronegócios, um importante caminho para a promoção do desenvolvimento nacional. Sendo a agroindústria bastante heterogênea, optou-se por restringir o presente trabalho à agroindústria de flores e plantas ornamentais no Estado de São Paulo, o principal produtor nacional (ANÉFALOS; GUILHOTO 2003).

Assim, no presente trabalho foi desenvolvido uma estrutura (framework) teórico-conceitual para análise das concentrações geográficas de empresas, relacionadas aos agronegócios de flores e plantas ornamentais brasileiras, visando o entendimento dos seguintes aspectos: processos prioritários para o desenvolvimento das ações conjuntas entre os atores locais; fatores indutores dos processos de inovação no contexto agroindustrial; processo de formação de competências coletivas e a de governança exercida na cadeia de valor.

O estudo de campo foi desenvolvido em duas das principais regiões paulistas de floricultura: Holambra e Mogi das Cruzes. Para tanto, foram levados em consideração, os aspectos relativos à produção, ao histórico da atividade agrícola, à área de plantio, à estrutura de comercialização e à organização de produtores, encontrados nestes municípios. A opção metodológica caracterizou-se pela aplicação de uma pesquisa exploratória nas duas regiões e de uma pesquisa quantitativa do tipo levantamento (survey) com os produtores rurais dos dois municípios estudados. 


\subsection{JUSTIFICATIVA}

A justificativa para o desenvolvimento do presente trabalho se fundamenta em três vertentes de argumentação: a importância dos agronegócios para o atual contexto sócio-econômico brasileiro, da importância crescente da floricultura ${ }^{1}$ no contexto dos agronegócios brasileiros e da carência de estudos de concentrações geográficas de empresas neste contexto.

Diversos estudos têm mostrado que as concentrações geográficas de empresas apresenta um papel de destaque no desenvolvimento econômico de vários países. Nos Estados Unidos, os estudos relativos às pequenas e médias empresas de base tecnológica, situadas na região do Vale do Silício, mostram a relevância deste tipo de organização industrial para a promoção e contribuição ao desenvolvimento local. $\mathrm{Na}$ a Itália, os estudos referentes aos distritos industriais revelam a importância que as concentrações geográficas de empresas para o desenvolvimento nacional tem, especificamente para a região conhecida como "terceira Itália" (CARVALHO; LAURINDO,2003; IGLIORI, 2000; AMATO NETO, 2000; SCOTT; STORPER, 1988; PORTER,1998). Além da importância relativa aos países considerados desenvolvidos, o estudo das concentrações geográficas de empresas também exerce importante papel no contexto econômico de paises em desenvolvimento. Schmitz (1997) destaca uma série de estudos que buscaram entender como a concentração geográfica de empresas nos países em desenvolvimento pode criar condições para competição no mercado externo, principalmente quando formados por pequenas e médias empresas.

Nesse tipo de estudo, torna-se fundamental a análise das relações entre os segmentos de uma cadeia de valor (relações verticais) dentro do mesmo segmento/elo (relações horizontais). Torna-se necessário então mapear as relações entre os fornecedores e os compradores; as interações dos produtores locais entre si e deles com instituições locais (associações de classe, poder público, agentes de financiamento, etc). Para Tálamo e Carvalho (2004), as relações específicas de

\footnotetext{
1 Aqui considerada como a atividade relacionada à exploração de plantas para finalidades ornamentais e estéticas. Assim, estão englobados nesta abordagem, todas as atividades relacionadas ao cultivo de flores, folhagens de corte, mudas em geral, plantas envasadas, gramas e forrações.
} 
cooperação entre empresas, trazem reflexos significativos na estrutura de governança da cadeia em que elas estão inseridas.

Em trabalho realizado num ambiente de empresas de tecnologia, Carvalho et al. (2000) apontaram a necessidade da realização de estudos que permitissem o mapeamento de locais, onde se desenvolvia de forma concentrada, o processo de formação de competências específicas em determinados setores

Considerando o atual momento de reestruturação social existente no Brasil, em que a melhoria no desempenho da balança comercial é um dos objetivos a serem alcançados, tem-se na melhoria das condições competitivas das concentrações geográficas de empresas no Brasil, um caminho a ser explorado.

A balança comercial brasileira traz uma série histórica com mais de quinze anos consecutivos com superávit das atividades agroindustriais (ALIMANDRO et al. 2001). Historicamente os agronegócios representam um dos setores que mais divisas gera para o País (CARVALHO; SILVA, 2006), sendo responsável por cerca de um terço do PIB nacional há mais de 20 anos (ABAG, 2001ALIMANDRO et al. 2001; IPEA, 2004; MAPA, 2006). Além disso, cerca de $37 \%$ da população economicamente ativa estão relacionadas aos agronegócios, o setor que mais gera empregos na economia brasileira, depois da construção civil (MAPA, 2006).

Dados oficiais do Ministério da Agricultura Pecuária e Abastecimento - MAPA mostram que o superávit observado nesses últimos anos vem se mantendo. Em 2004, a balança comercial do agronegócio brasileiro apresentou um crescimento recorde de $32,1 \%$ em relação ao ano anterior. Também com relação às exportações houve um expressivo crescimento em relação a 2003: $27,3 \%$, segundo análise do próprio Ministério da Agricultura (MAPA, 2005). Até final de setembro de 2006 o saldo da balança comercial desse setor havia registrado a marca de US\$31,27 bilhões, resultado 8,9\% superior ao saldo verificado no mesmo período de 2005 . Este saldo representa $86,7 \%$ do saldo total da balança comercial brasileira no período (INDICADORES RURAIS, 2006).

Esse cenário positivo também se reflete para o setor de flores e plantas, que vem mantendo, desde 1997, uma tendência de saldo positivo na balança comercial. A partir de 2002, esta tendência se acentuou, apresentando em 2004 um crescimento de 33,2\% em relação a 2003 (KIYUNA et al. 2003). KIYUNA et al. (2003) estimaram o valor da produção nacional de flores para o ano de 2002 , em R\$ 
500 milhões ao nível dos produtores, implicando num valor próximo a $\mathrm{R} \$ 750$ milhões ao nível de atacado e de $\mathrm{R} \$ 1,5$ bilhão na esfera do varejo.

O desenvolvimento da floricultura no País, quando comparado a outras atividades agrícolas, apresenta no geral uma alta rentabilidade, associada ao rápido retorno do capital investido (Yamamuchi, 1995, apud CLARO; OLIVEIRA, 1999). O trabalho apresentado por Almeida (2004), mostra que, as atividades relacionadas aos agronegócios de flores podem chegar a um rendimento dez vezes superior a média do rendimento obtido com o cultivo de frutas como banana, uva, abacaxi e uva. Segundo Claro (1998) a produção de flores gera uma grande rentabilidade por área cultivada e retorno rápido do capital empregado.

Além disso, a floricultura é uma das atividades agrícolas que gera um número elevado de empregos fixos, o quê não é comum dentre as mais importantes atividades agrícolas do país. Este alto índice de utilização de mão-de-obra, está em torno 15 a 20 pessoas/ hectare (CLARO, 1998; KIYUNA et al.2003), resultando em mais de 120 mil empregos diretos (IBRAFLOR, 2006). Segundo Anefalos e Guilhoto (2003) para cada R\$ 1 milhão investido, a floricultura gera 404,24 novos empregos, quase quatro vezes mais a geração de empregos observada nos agronegócios brasileiros como um todo. Essa mão-de-obra tem um melhor nível de qualificação se comparada com as demais atividades agrícolas e apresenta, segundo Francisco et al. (2003a), uma importância crescente nos processo geração de valor desse setor em termos nacionais.

Kiyuna et al. (2003) também destacam a importância desse tipo de atividade agrícola, no contexto da análise estratégica dos agronegócios brasileiros, dado pelo elevado grau de tecnologia aplicado em seus processos de produção. Segundo esses autores, essa tecnologia é em grande parte desenvolvida no Brasil.

Essas condições são essenciais para o desenvolvimento das competências necessárias para o destaque competitivo da floricultura brasileira, tanto no nível local, como global, conforme também pode ser observado nos resultados da balança comercial, já relatados.

Portanto, o presente estudo justifica-se na medida em que se busca contribuir para uma melhor compreensão da dinâmica das concentrações geográficas de empresas relacionadas aos agronegócios de flores e plantas ornamentais que, raramente abordada nos estudos empíricos. Além disso, busca-se também com esse trabalho, contribuir para a formação de um conhecimento especifico capaz de 
auxiliar na identificação e construção de uma estrutura analítica para a concepção das estratégias competitivas das concentrações geográficas de empresas relacionadas aos agronegócios.

\subsection{OBJETIVOS DO ESTUDO}

A proposta para realização do presente trabalho traz como principal objetivo estudar os fatores determinantes para geração das vantagens competitivas ao conjunto de empresas pertencentes a uma dada concentração geográfica de empresas relacionadas aos agronegócios de flores e plantas ornamentais brasileiro, doravante denominado apenas agronegócio de flores. Com isso, busca-se contribuir para a construção de um conhecimento específico, capaz de ser utilizado no desenvolvimento de estratégias conjuntas e individuais, voltadas à promoção de melhores condições competitivas a essas empresas e à localidade em que estejam inseridas.

Neste contexto, derivam-se deste objetivo principal os seguintes objetivos específicos:

1. Elaborar uma estrutura (framework) teórico-conceitual das abordagens e conceituações referentes aos estudos das concentrações geográficas de empresas, com vistas a identificar os aspectos convergentes que possam auxiliar no desenvolvimento da concepção estratégica da abordagem aqui proposta para o contexto do agronegócio de flores.

2. Analisar a estrutura de governança da cadeia produtiva do agronegócio de flores na concentração estudada e da forma de ação dos agentes de coordenação (públicos e privados), visando identificar o papel dessa estrutura na formação das vantagens competitivas da concentração geográfica de empresa.

3. Identificar os principais fatores indutores para o estabelecimento de ações conjuntas nas relações verticais e horizontais do sistema produtivo de flores, ou seja, entre os produtores rurais e entre eles e os demais agentes, como forma de diferenciar esse tipo de ação

4. Identificar os principais fatores indutores da inovação e da formação das competências coletivas. 
Destaca-se, que o presente trabalho será desenvolvido em um ambiente especifico de empresas agrícolas de produção e serviço de flores, que, conforme comentado, apresenta algumas características singulares, que podem ser restritivas a sua extensão a outros agronegócios. Além disto, o trabalho foi desenvolvido no Estado de São Paulo, que embora seja o líder nacional dos agronegócios de flores, também apresenta características específicas que podem também restringir a extensão das conclusões deste estudo para o cenário nacional.

\subsection{ESTRUTURA DO TRABALHO}

Este trabalho encontra-se estruturado em sete capítulos, a considerar este, onde estão apresentadas as informações referentes à caracterização do problema estudado, bem como sua contextualização no cenário econômico e empresarial no qual o mesmo se relaciona e a contribuição maior do estudo aqui proposto. Nesse capítulo, encontram-se ainda as principais justificativas que retratam a relevância do tema estudado, os objetivos a serem alcançados e a estrutura utilizada neste documento.

No Capitulo 2 encontra-se a revisão bibliográfica referente ao arcabouço teórico utilizado para sustentação deste trabalho. O capítulo é organizado em torno de quatro grandes temas direcionadores deste estudo: concentração geográfica de empresas; agronegócios, estratégia empresarial/ competitividade e Cadeia de Valor/Governança. Uma vez que o foco deste de trabalho se mostra voltado para a concentração geográfica de empresas, optou-se por fazer uma revisão mais detalhada sobre as principais abordagens teóricas sobre esse assunto. $\mathrm{O}$ capítulo termina com a proposição da estrutura (framework) teórico-conceitual para a tese.

No Capitulo 3 encontra-se detalhado o procedimento metodológico proposto para o desenvolvimento desta tese bem como as limitações relacionadas ao objeto do presente estudo.

No Capitulo 4 optou-se por caracterizar o ambiente onde se insere o objeto de estudo. Para tanto é detalhada a importância dos agronegócios para o contexto 
socioeconômico brasileiro, seguido da caracterização e da relevância da floricultura no contexto nacional e do Estado de São Paulo. Por fim é feita uma caracterização das duas regiões estudadas: Holambra e Mogi das Cruzes. Este capítulo é basicamente elaborado com base em revisão bibliográfica e de dados secundários referentes a aspectos socioeconômicos locais.

No Capitulo 5 é feita a apresentação detalhada dos resultados da pesquisa de campo qualitativa. Na conclusão do capítulo, os resultados são discutidos com base nas proposições da pesquisa.

O Capítulo 6 apresenta os resultados referentes à pesquisa quantitativa (survey) e os discute com base nas hipóteses desta tese.

Finalmente, no Capitulo 7 é apresentada a conclusão do trabalho, com base nos objetivos, nas proposições da pesquisa qualitativa e nas hipóteses da pesquisa quantitativa. Neste capítulo, optou-se também por apresentar os principais desafios observados no transcorrer deste trabalho seguido de uma proposta para a continuidade dos estudos nessa linha, baseados nos resultados aqui obtidos.

Em seqüência são apresentados as referências e os anexos utilizados nesta tese. 


\section{CAPÍTULO 2. ARCABOUÇO TEÓRICO}

Este capítulo faz a síntese da discussão teórica da tese. Está organizado em torno dos quatro grandes temas direcionadores deste estudo: concentração geográfica de empresas; agronegócios, estratégia empresarial/ competitividade e Cadeia de Valor/Governança. O capítulo termina com a proposição da estrutura (framework) teórico-conceitual utilizada no tratamento e análise da parte empírica desta tese.

\subsection{CONCENTRAÇÃO GEOGRÁFICA E SETORIAL DE EMPRESAS}

\subsubsection{Abordagem Contextual}

No final do Século XIX, alguns estudiosos já consideravam em suas obras, as forças da aglomeração local como fator influenciador das atividades econômicas locais (IGLIORI,2000). Foi a partir da década de 1970, quando na Europa algumas regiões mostravam um desempenho econômico bastante elevado, que o interesse pelo estudo das aglomerações de empresas cresceu de maneira expressiva (AMATO NETO, 2000; IGLIORI, 2000). A grande maioria desses estudos, tinham como foco os efeitos desse tipo de organização industrial na competitividade das empresas. Foi a partir dos trabalhos de Michel Porter (1993, 1998) que esses estudos começaram a ganhar uma dimensão estratégica maior, voltada para a importância desse tipo de organização empresarial na competitividade dos países.

Esse crescente interesse pelo estudo das concentrações geográficas de empresas no contexto da competitividade dos locais, países ou regiões, segundo Porter (1993) é fruto da "difusão e intensificação da competição" que não sustenta a argumentação de muitos teóricos que segundo esse autor, afirmam ter diminuído a importância da localização, na medida em que aumenta a mobilidade do capital e da tecnologia. Nesse sentido, o autor questiona esse tipo de argumentação e propõe um referencial teórico que busca explicar como a prosperidade das empresas locais e/ou de nações, depende do ambiente local onde ocorre à competição. 
...embora, de uma forma ou de outra, o fenômeno dos aglomerados tenha sido reconhecido e explorado através de vasta literatura, é impossível entendê-los fora de um contexto mais amplo, da competição e da influência da localização na economia global...

Porter (1993)

Apesar de reconhecer o crescente interesse da comunidade acadêmica pelo estudo das concentrações geográficas de empresas, Porter (1993) destaca que esses estudos, em sua grande maioria, traziam à época uma visão muito simplificada sobre a influência das concentrações na competitividade das empresas. Para Porter, esses estudos encaram a competição como um fenômeno estático em que a vantagem dos fatores de produção (especificamente mão-de-obra e o capital), induziam a um contexto de economias de escala, mascarando o verdadeiro cenário competitivo atual "que se fundamenta na inovação e na busca das diferenças estratégicas" (Porter, 1998). Nesse estudo ainda, o autor destaca a importância do poder público nesse tipo de concentração empresarial, como sendo o responsável pela formação populacional e pelas questões relacionadas à infra-estrutura local, agente legislador e agente responsável pelo estabelecimento de políticas públicas setoriais, entre outras.

Mais tarde, Steinle e Schiele (2002), estudando a relevância do fenômeno da concentração geográfica de empresas, destacam vários trabalhos que apresentam uma abordagem já distante daquela criticada por Porter (1998). Esses autores, destacam que muitos dos trabalhos citados, mostram diferenças entre os efeitos das concentrações geográficas de empresas sobre diferentes empresas ou setores, que reforça a problemática desta tese.

Para Nadiv e Schmitz (1999) a importância das concentrações geográficas de empresas, traz uma relação direta com o estágio de desenvolvimento industrial do local. Segundo os autores, são mais importantes em locais onde há um estágio indústrial ainda pouco desenvolvido, onde é necessária a mobilização de recursos de maneira eficiente. Além disso, afirmam que nesse caso, são requeridas condições menores de talentos e habilidades por parte dos empresários locais. Nesse estudo ainda, os autores afirmam que os resultados empíricos mostram que é comum a existência de um número expressivo de pequenas e médias empresas nesses arranjos. 
Schmitz (1997) relata que as concentrações geográficas de empresas têm ajudado as firmas de pequeno e médio porte, sobretudo nos países em desenvolvimento, a melhorarem significativamente seu desempenho, inclusive com a sua inserção em mercados externos. No entanto, procura não construir um conceito de que esses agrupamentos sejam uma forma das pequenas e médias empresas superarem as grandes no cenário mundial. Isso segundo o autor, foi realidade no período entre 1970 e 1980 e em algumas regiões específicas da Itália, mas tal situação já não ocorre mais, uma vez que as grandes corporações já se mostram hoje bem mais flexíveis do que naquela época, impossibilitando assim que venha a ocorrer novamente.

Outro estudo realizado por Schmitz desta vez tendo como objeto a indústria calçadista da região sul do Brasil voltada para exportação, mostrou que houve de um lado, uma melhora acentuada na qualidade, rapidez de entrega e flexibilidade de produção, dada pelo relacionamento positivo e cooperativo entre as partes (SCHMITZ,1995).

No estudo realizado por Schmitz (1995), foi realçado que um grande programa para a promoção do sapato brasileiro, não teve sucesso, devido a um conflito de interesses estratégicos gerado pela opção de um importante grupo de empresas do local em estreitar seu relacionamento comercial com um grande varejista (global buyer). Isso acabou por comprometer o desempenho do cluster como um todo.

Com relação a presença desses compradores no setor calçadista, também no sul do Brasil, Garcia (2003), observou forte influencia desses agentes na organização das cadeias locais e nas estratégias de determinadas empresas, fato esse bastante evidenciado nesse estudo de Schmitz (1995). Um ponto convergente entre esses estudos, foi que Garcia (2003) também destaca que a presença desses agentes, afetou positivamente o desenvolvimento das áreas de produção, na mesma medida em que afetou negativamente as áreas de desenvolvimento de produto e comercialização, cujo domínio era exercido estrategicamente por esses agentes.

Num estudo também relacionado à presença de compradores globais, Bair e Gereffi (2001), observam que a presença desses agentes foi benéfica ao que os autores denominaram de "dinamismo de exportação", nas indústrias mexicanas de jeans, na localidade de Torreon. Com base nesses resultados os autores destacam 
que as pesquisas sobre agrupamentos empresariais, devem buscar congregar a perspectiva do estudo das cadeias globais. Em linhas gerais, esse estudo mostrou a importância desse tipo de comprador como agente dinamizador da economia local, principalmente no contexto estudado, onde o México aderia ao NAFTA (North America Free Trade Agreement). Vale ressaltar que nesse estudo, os autores detectam um nível de confiança e de relacionamento entre as empresas, muito fraco, fazendo com que as ações conjuntas fossem praticamente inexistentes. Se isso por um lado mostrou o enfraquecimento das empresas de Torreon, por outro, fortaleceu o poder dos compradores globais, que com isso, alcançam um poder elevado de coordenação de funções estratégicas da cadeia, assim como observado por Garcia (2003).

Se nesse estudo, Bair e Gereffi (2001), observam uma fraca interação no relacionamento entre as empresas mexicanas em Torreon, por outro lado, um estudo anterior, realizado por Nadiv (1999), atribui ao bom desempenho de algumas empresas paquistanesas de material cirúrgico a uma efetiva troca de relações cooperativas entre elas, principalmente com os compradores, que atuavam como importante vetor de informações. Isso possibilitou o desenvolvimento tecnológico necessário, valendo-se do fato de que no agrupamento estudado, já havia uma concentração de mão-de-obra especializada. Por fim, esse estudo revelou que, locais aonde não havia a devida exploração das ações cooperativas, apresentam dificuldades em contornar situações de crise.

Num estudo realizado no setor calçadista na cidade mexicana de Guadalajara, Rabelotti (1997) analisou o impacto da liberação comercial sobre o setor e seus reflexos no comportamento cooperativo. Segundo a autora os resultados mostraram que houve um maior fluxo na troca de informações, trazendo, além dos benefícios observados por Schmitz (1995): controle da qualidade e rapidez na entrega dos produtos e uma expressiva troca de informações referentes ao desenvolvimento conjunto de produtos. Nesse estudo ficou evidenciado também um aumento na quantidade de fornecedores no cluster, após a liberalização comercial, o que trouxe como beneficio direto e imediato, a diminuição nos custos de transporte de insumo. De maneira geral, esse estudo enfatiza que houve uma contribuição significativa das ações cooperativas, frente ao desenvolvimento das empresas estudadas. 
Com relação especifica aos estudos, relacionados à área dos agronegócios brasileiros, tem-se observado que os trabalhos da Fundação Getúlio Vargas (FGVSP), em São Paulo, estão mais voltados às cadeias alimentares da carne e da soja, excluindo-se ai o grande número de estudos que se tem desenvolvido sobre a indústria calçadista de couro. Trabalhos nesse sentido também são desenvolvidos com maior freqüência pelo Grupo de Pesquisas Agroindústriais (GEPAI) da Universidade Federal de São Carlos (UFSCAR).

Dentre os trabalhos realizados pela equipe de estudos dos agronegócios da FGV-SP, um deles, por apresentar um forte caráter pioneiro na utilização do termo "agricluster" nesses estudos brasileiros, merece destaque. Trata-se do estudo realizado por Brum e Wedekin (2001) que, tendo como base o conceito de cluster, apresentado por Porter (1998). Os autores fazem um estudo detalhado da região sudoeste de Goiás, contemplando dezoito municípios, onde observaram as seguintes características:

a) A presença de uma concentração geográfica e setorial de empresas relacionadas as cadeias de frango de corte e suíno.

b) Presença de uma cadeia produtiva vertical de empresas e instituições.

c) Relações fortes de complementaridade entre empresas de diferentes setores.

d) Instituições capazes de formar mão-de-obra qualificada.

e) Presença de agentes governamentais.

Dentre os trabalhos realizados pelo GEPAI, o trabalho de Campeão (2004) merece destaque na medida em que se propôs a desenvolver um modelo para avaliação competitiva de concentrações geográficas empresariais, sob o enfoque da promoção do desenvolvimento local. A autora baseou seu modelo no capital humano, institucional e organizacional e obteve resultados, mostrando que esses pilares estudados podem servir de base estudos voltados ao aprimoramento do conhecimento gerado.

Steninle e Schiele (2002), evidenciam que os setores são afetados diretamente pelos clusters, que motivou aos autores elaborarem um modelo para avaliar a propensão de um determinado setor se concentra em uma dada região ou 
país. Essas observações levaram os autores a concluírem que naquela região extensa, estava caracterizado um cluster, segundo modelo de Porter (1998).

Por fim, vale destacar que, através das experiências empíricas aqui relacionadas, pode-se dizer que as vantagens competitivas das concentrações geográficas de empresas,estão baseadas fortemente nas inter-relações das economias externas e locais e as ações coletivas. Assim, quando se visa o estudo de tais organizações indústriais, sob o enfoque estratégico, estudar esses pilares em seus aspectos constituintes e entender suas inter-relações, torna-se um desafio contundente

\subsubsection{Abordagem Teórica}

A literatura acadêmica apresenta uma extensa gama de trabalhos, em que diferentes conceitos e definições para o estudo das concentrações geográficas e setoriais de empresas são apresentados. Denominações como clusters, arranjos produtivos locais, sistemas locais de produção, aglomerados empresariais, adensamento geográfico de empresas, entre outras, são comumente utilizadas em estudos dessa natureza.

Isso se dá na medida em que os estudos referentes às concentrações geográficas de empresas são desenvolvidos sob o enfoque de diferentes áreas do conhecimento humano, conforme já abordado no capitulo inicial deste trabalho. Para Humprey e Schmitz (2000), esses estudos, podem ser divididos em quatro grupos: a nova geografia econômica; desenvolvimento regional; estudos relacionados à administração de empresas e ao desenvolvimento tecnológico.

Segundo Carvalho e Laurindo (2003) três aspectos contribuem para a discussão da concentração local: governança global, governança local e inovação. O tipo de governança na cadeia em que está inserido o cluster, exerce forte influência na possibilidade de desenvolvimento da indústria (indústrial upgrading) e do tipo de mercado alcançado local ou global. O tipo de governança local busca identificar a existência de uma empresa-líder que condicione as estratégias das demais empresas do cluster e o potencial das ações conjuntas de colaboração. A dimensão 
da inovação ou da tecnologia do cluster também tem impacto na sua competitividade.

Independentemente da área em que tais estudos sejam desenvolvidos, existe a necessidade mútua da consideração dos aspectos intra e inter organizacionais, dos aspectos da territorialidade e suas inter-relações. Assim, considerando essas perspectivas, encontra-se na literatura duas abordagens teóricas bem características no estudo das concentrações geográficas de empresas e que se relacionam ao trabalho aqui desenvolvido: a abordagem teórica dos distritos industriais e dos clusters.A seguir são apresentadas as principais características de cada uma dessas abordagens citadas.

\subsubsection{Distritos Industriais}

O conceito de distrito industrial data do final do século XIX, apresentado por Marshall, baseado em sistemas de produção desenvolvidos por pequenas unidades produtivas, especializadas cada qual, numa função específica do processo (IGLIORI, 2000).

Para Schmitz (1995), as principais características desse tipo de organização indústrial se concentram nos seguintes fatores: na proximidade geográfica das empresas que participam do distrito; na especialização setorial da produção; na predominância de pequenas e médias empresas; na colaboração próxima entre as firmas; na competição entre as firmas baseada na inovação; na identidade sóciocultural; em organizações ativas que dão suporte para as atividades do distrito e no suporte dos governos estadual e municipal.

Este tipo de organização industrial é capaz de atender a um importante requisito competitivo imposto pelo atual cenário mundial: a flexibilidade. (SCHIMITZ, 1989). Essa flexibilidade permite aos distritos industriais, apresentarem uma maior variedade de produtos e com isso, desenvolver e explorar novas tecnologias (SCHMITZ, 1989). Para Humprey (2003) os principais processos de produção se concentram nesses distritos, que muitas vezes podem compreender todos 0 processo de fabricação de um bem. 
Para Igliori (2000), os estudos sobre os distritos indústrias italianos marcam uma nova época investigativa sobre a importância da localização como fonte geradora de vantagens competitivas. Nesse processo, novas abordagens foram apresentadas, ganhando força a discussão do papel das instituições locais e das vantagens estratégicas.

Isso posto, pode-se observar que há uma convergência nos trabalhos supra relatados, que de maneira geral, os distritos indústriais se caracterizam por ser um aglomerado formado prioritariamente por pequenas e médias empresas, trabalhando em conjunto, de maneira integrada, com marcada felxibilidade e forte interação ao ambiente sócio-cultural local.

\subsubsection{Clusters}

Em seu trabalho referência, Porter (1998) define como cluster "um agrupamento geograficamente concentrado de empresas inter-relacionadas e instituições correlatas em uma determinada área, vinculadas por elementos comuns e complementares". Para esse autor, essas inter-relações ocorrem num processo interativo que acabam por gerar a capacidade inovativa e o conhecimento especializado, os quais são grandes responsáveis por gerarem a vantagem competitiva local.

Ainda para Porter (1998) os clusters apresentam, em sua grande maioria, fornecedores de produtos especializados, empresas situadas no extremo da cadeia, instituições financeiras e setores correlatos, fabricantes de produtos complementares, fornecedores de infra-estrutura especializada, instituições de pesquisa, treinamento, suporte técnico, entre outros. Porter(1998) destaca ainda que muitos congregam associações comerciais de caráter privado e/ou outras entidades associativas. Ainda nesse estudo, o autor ressalta que nem sempre os clusters apresentam uma clara definição de suas fronteiras geográficas, estando essa fundamentada na identificação dos elos e da competitividade do local em seus mais variados níveis. No estudo em que considera abordar uma das mais importantes idéias de sua teoria geral para competitividade, Porter (1998) traz, de maneira 
detalhada, a discussão de uma série de vantagens proporcionadas pelos clusters, resumidas a seguir:

a) Acesso a insumos e pessoal especializado: com melhor qualidade e custo mais baixo, geralmente fundamentadas nas alianças formais com entidades não pertencentes ao cluster ou a "importação" de outros centros.

b) Fluxo de informação: a concentração geográfica de empresa proporciona maior concentração de informações (técnicas e de mercado) que estariam presentes tanto nas empresas como nas instituições locais, diminuindo o custo para sua obtenção. Tal benefício estaria relacionado aos fortes elos decorrentes da proximidade das empresas, das relações com fornecedores e também dos laços comunitários que influenciam nas relações pessoais, aumentando a confiança entre as partes, facilitando assim o fluxo de informações na concentração.

c) Complementaridade: as facilidades de aquisição e montagem de insumos, associadas as demais facilidades do cluster, facilitam as atividades de complementaridade entre as atividades dos diferentes participantes.

d) Eficiência de Compra: a possibilidade de acesso a mais de um fornecedor em uma visita e a presença de várias fontes para um mesmo produto ou serviço, aumenta a eficiência da compra, ao mesmo tempo em que reduz o risco para o comprador.

e) Incentivo e medição de desempenho: a pressão interna exercida pela rivalidade local, onde existe uma grande facilidade para comparação constante, que acaba por incentivar a medição do desempenho e melhoria constante.

f) Disponibilização de mão-de-obra especializada: a concentração de mão-deobra reduz seus custos de busca e de recrutamento, possibilitando maior compatibilizarão entre pessoas e cargos.

g) Redução das atividades oportunistas: a proximidade entre as partes do cluster e o encadeamento das atividades, estrutura uma forte dependência entre as partes, onde o mau desempenho de uma delas compromete o sucesso das demais. Além disso, as facilidades de difusão das informações associadas ao desejo de manutenção da boa reputação, tirando o incentivo a ocorrência de 
atividades oportunistas que enfraqueceriam os níveis de relacionamento local, que por sua vez, garantem a estabilidade competitiva do cluster.

h) Redução dos custos de transação: o fluxo maior de informações, associado as relações mais próximas (tanto ao nível comercial, como ao nível pessoal), geram um ambiente de maior confiança entre os atores, que por sua vez exercem uma pressão positiva na diminuição dos custos de transação, especificamente considerado na inibição que os clusters apresentam para as atividades oportunistas.

i) Formação de novas empresas: o ambiente dos clusters proporciona a melhoria de diversos fatores, os quais aqui alguns já foram discutidos. Entretanto, entre eles, a melhoria das informações sobre oportunidades de novos negócios, proporciona a abertura de novas empresas, na medida em que cria-se a possibilidade para que aqueles indivíduos já pertencentes à uma empresa, deixem-nas para abrirem seu próprio negócios. Para Porter (1998), a própria existência do cluster sinaliza uma oportunidade.

Vários autores destacam algumas das vantagens competitivas na mesma linha de Porter (1993), como por exemplo, a criação de condições propícias para a presença de fornecedores na região, a disponibilidade e especialização da mão-deobra local, acesso às matérias-primas e diminuição dos custos de transação (PORTER 1993, 1998; AMATO NETO 2000; CASSIOLATO; LASTRES 2001; IGLIORI, 2000; SUZIGAN et al. 2002).

Cassiolato e Lastres (2001) destacam que a concentração geográfica pode proporcionar melhor organização das empresas, aumentando seu poder de barganha junto aos sues fornecedores criando condições não só para ganhos de escala, mas também ações para que haja mais investimentos em pesquisa e desenvolvimento além de ações conjuntas de comercialização permitindo acesso a outros mercados. Segundo Carvalho e Laurindo (2003), essas ações constituem um dos mais importantes pilares para criação de vantagens competitivas sustentáveis nas concentrações geográficas de empresas

Corroborando com a idéia de Porter (1998), que os clusters representam uma importante forma de diálogo entre sues componentes, Câmara et al.(1999) consideram que a análise dos arranjos locais permite o estudo das organizações 
neles presentes, a partir da discussão dos principais agentes constituintes da competitividade local. Para este autor, a inter-relação entre esses agentes pode contribuir muito para aumentar as relações entre empresas, direcionar treinamentos nos diferentes níveis, facilitar acesso aos recursos técnicos e financeiros, incrementando as vantagens competitivas já existentes e com isso, acelerando o desenvolvimento local.

Suzigan et al. (2001) relatam que "As empresas locais usualmente interagem por meio de linkages de produção, comércio e distribuição. Elas também cooperam em marketing, promoção de exportações, suprimento de insumos essenciais, atividades de $P$ \& D e outras ". Além disso, esses autores destacam que associado a esses elementos, faz-se necessária a "existência de algumas formas de identidade política, social ou cultural, a base para a existência de confiança e compartilhamento de informações". Abordagem semelhante é feita por Lins (2000), que julga ser tais aglomerações, uma condição necessária para que a articulação entre economias externas e ação conjunta favoreça o vínculo entre as empresas de natureza vertical e de natureza horizontal.

\subsubsection{A Inovação no Contexto das Concentrações Geográficas de Empresas}

Segundo Silva (2000) inovação é o resultado dos processos de incorporação do conhecimento a novos produtos e processo de produção. Já para Humprey e Schmitz (2000), o conceito de inovação está relacionado a idéia upgrading, ou seja, uma nova forma de fabricação mais eficiente de produtos, capaz de gerar agregação freqüente de valor. Para esses autores, pode ser encontrados três tipos desse "upgrading", ou seja, dessa nova forma de fabricação: upgrading de processo (relacionado a reorganização do sistema de produção ou à adoção de novas tecnologias); upgrading de produto (produtos com maior valor agregado) e upgrading funcional, (relacionado à adoção de novas funções que a a empresa possa vir a desenvolver, no contexto da cadeia de produção)

Para Dosi (1986) apud Miglino (2003), a inovação está relacionada à busca e descoberta, a experimentação, ao desenvolvimento, à imitação e adoção de novos produtos, processos de produção e novas soluções organizacionais. 
Furman et al. (2002), relatam que há muito tempo o estudo do papel da inovação no contexto competitivo atual, de empresas e nações, vem sendo estudado sob diversos enfoques analíticos e destacam especialmente,a relevância do papel da localidade e sua relação com a intensidade da inovação presente.

A relevância desse assunto é reforçada pelos autores que citam vários estudos, entre eles Porter (1990 e 1998), Dosi (1986) apud Miglino (2003) e Montgomery e Nelson (1999) apud Furman et. al. (2002), cujos trabalhos enfatizam a importância da dinâmica da inovação em agrupamentos de empresas e instituições específicas, dentro de determinadas áreas geográficas.

Na teoria da vantagem competitiva das nações (PORTER, 1990), a questão da inovação se faz presente em quatro diferentes pilares: disponibilidade de entradas para inovação, incentivos à inovação, existência de clientes sofisticados e a capacidade de relacionamentos entre as empresas. Esta última, segundo o autor,é responsável pela geração de "spillovers", externalidades positivas, que são realçados quando esses agrupamentos estiverem concentrados num espaço geograficamente definidos. Neste contexto, Porter (1993), destaca que a inovação é um dos principais benefícios apresentados pelos clusters, quando comparados a localizações isoladas, pois para o autor, esse tipo de ambiente estimula o relacionamento constante com entidades do grupo, visitas freqüentes e contatos diretos "face a face", que inseridos num ambiente que também estimula a competição, trazem como uma de suas conseqüências, o estimulo a inovação. Além disso, esse autor destaca também que a similaridade de alguns fatores como, 0 custo de mão-de-obra e infra-estrutura, considerados num ambiente de extrema competição (extrema presença de rivais), acaba por obrigar com que as empresas busquem outras formas de se distinguirem uma das outras, criando então aquilo que o autor denominou de "intensa pressão pela inovação". Além disso, o autor destaca mais três fatores que reforçam a importância dos clusters no processo inovativo das empresas: a capacidade de adquirir com maior rapidez novos insumos necessários para a inovação; a possibilidade de reduzir os custos de pesquisas e a possibilidade de retardar comprometimentos futuros, até que seja evidenciado o sucesso da inovação testada.

No entanto, esse mesmo autor ressalta que ao mesmo tempo em que os clusters podem proporcionar um estímulo ao processo de inovação, podem também 
inibi-lo sob certas condições específicas, quando por exemplo, este processo tende a invalidar o pool local de talentos ou de informações, fornecedores ou ainda afete a infra-estrutura local.

A importância da inovação no contexto das concentrações geográficas de empresas é também realçada por Carvalho e Laurindo (2003), que julgam ser esse um dos conceitos básicos para a análise e discussão da competitividade desse tipo de arranjo industrial.

Igliori (2000) destaca alguns estudos que relacionam a influência dos aspectos espaciais no processo de inovação e vice versa, onde há a influencia da inovação sobre o desenvolvimento do espaço, principalmente quando se tem um eficiente sistema de comunicação que promove a difusão do conhecimento e com isso estimula novas atividades promotoras da inovação.

Para Groot (1999), a alta competitividade apresentada pela Holanda na produção de flores está relacionada a sua alta capacidade de inovação, principalmente dos processos e tecnologia, que a faz competitiva internacionalmente em termos de custos.

Farina et al. (1997) destacam a importância do ambiente institucional para o desenvolvimento do processo de inovação. Para os autores, as instituições ${ }^{2}$ influenciam as estratégias das organizações e na diminuição das incertezas que surgem nas relações sociais e econômicas. Isso mostra que a importância das instituições, também está relacionada a sua relação com os custos de transação, possibilitando maior eficiência nas relações entre os agentes e modificando as expectativas de risco, uma vez que aumentam o grau de confiança. Assim, entre outras condições, esse cenário acaba por favorecer a criação de um ambiente capaz de promover também o processo de inovação.

Cassiolato e Lastres (1999), enfatizam que o processo de inovação não se restringe apenas às atividades de produção exclusivas das empresas. Para esses autores, tal processo é também relacionado à troca de informação entre as empresas e entre elas e os organismos de desenvolvimento (universidades, agencias de governo, etc.) num contexto em que também as características

\footnotetext{
2 Segundo FARINA et. Al (1997) são regras que delimitam as escolhas do indivíduo numa sociedade, dão forma à interaçào social que se configura numa sociedade, podendo ser regras formais (direitos de propriedade, leis, sistema judiciário, etc.) ou informais (códigos de conduta, cooperaçào, confiança, etc.)
} 
históricas, culturais e econômicas locais sejam consideradas. Essa abordagem foi corroborada posteriormente por Garcez (2000), que desvinculou o processo de desenvolvimento da inovação das atividades exclusivas de pesquisa e desenvolvimento, desenvolvidas no interior da organização. Silva (2000) também vai de acordo com as colocações de Cassiolato e Lastres (1999), na medida em que atribui as relações horizontais de colaboração, entre concorrentes ou entre as empresas e organismos de pesquisa e/ou fomento, papel fundamental no processo de inovação.

Nesse contexto, observa-se que o ambiente criado numa concentração geográfica de empresas, em que existam fortes relações de parcerias, o papel da inovação torna-se ainda mais importante, na medida em que tal condição acaba por induzir ao desenvolvimento desse processo, que por sua vez, é o ponto critico quando se visa garantir a competitividade das empresas e do conjunto como um todo.

Pelo exposto é possível verificar que, as concentrações geográficas de empresas assumem papel fundamental no processo de inovação, uma vez que por intermédio das ações conjuntas, relações de governança e do próprio processo de desenvolvimento das competências locais, acaba por gerar um ambiente favorável a este processo

\subsubsection{Ações Conjuntas e Eficiência Coletiva como fatores essenciais para análise estratégia das Concentrações Geográficas de Empresas.}

Cassiolato e Lastres (2001) ressaltam que as concentrações geográficas de empresas propiciam, entre outras coisas já destacadas anteriormente, condições para que haja o estabelecimento de ações conjuntas, entre os atores que nela se relacionam. Segundo Awuah (2001), as relações inter-firmas torna-se um recurso que pode ser explorado para o desenvolvimento de competências, outro fator de significativa importância para a criação de vantagens competitivas sustentáveis, conforme Prahalad e Hammel (1990).

A importância das ações conjuntas foi reforçada no estudo publicado por Schmitz (1995) para caracterizar a vantagem competitiva gerada pelas economias externas e pela ação conjunta dos agentes locais. Posteriormente, em trabalho 
referente ao estudo de cluster calçadista no Brasil, Schmitz (1997) definiu quatro tipos de ações conjuntas, dividas em duas dimensões (número de envolvidos no processo e direção da cooperação). Sob a dimensão da quantidade de atores envolvidos na a ação conjunta, o autor definiu que esta pode ser bilateral, onde duas empresas trabalham juntas, ou multilateral, onde grupos de empresas trabalham em conjunto. No que se refere à direção das ações, o autor destaca que esta pode se dar em caráter horizontal (entre os competidores) ou vertical (nos diversos estágios da cadeia de produção/distribuição).

\subsubsection{O Contexto Sócio-econômico das Concentrações Geográficas de Empresas: a Relação com as Redes Locais (sociais e empresariais) na Geração das Vantagens Competitivas da Localização}

Segundo Porter (1998), a estrutura social dos clusters assume o papel fundamental na construção coletiva das vantagens competitivas geradas numa localidade, que por sua vez, são sustentadas em três pilares: os relacionamentos, as redes e o interesse comum.

"A simples presença de empresas, fornecedores e instituições numa localidade cria o potencial para o valor econômico, mas não assegura, necessariamente, a realização desse potencial. Os vínculos sociais mantém a coesão dos aglomerados, contribuindo para o processo de criação de valor. Boa parte da vantagem competitiva dos aglomerados depende do livre fluxo de informações, da descoberta de intercâmbios e transações agregadoras de valor, da disposição de alinhar agendas e atuar além das fronteiras empresariais e da forte motivação para os aprimoramentos" (PORTER, 1998),

Assim, vê-se que questão estratégica presente na análise desses relacionamentos, assume vital importância como fator a ser considerado na geração das vantagens competitivas locais. Essas vantagens são criadas, segundo Porter (1993), num ambiente de redes que se desenvolvem em uma dada localidade geográfica "na qual a proximidade das empresas e instituições assegura certas formas de atividades e aumenta a freqüência das interações". 
O enfoque das redes no contexto das concentrações geográficas de empresas está relacionado à conceituação das redes como elementos componentes de uma visão estratégica mais ampla, envolvendo todos os setores sociais (economicamente ativos ou não), voltados para garantir a geração de instrumentos de mobilização de recursos sociais, econômicos e ambientais, capazes de gerar as riquezas necessárias para garantir competitividade local.

Aliado a isso, o estudo das redes no contexto estratégico, permite também subsidiar o entendimento das relações diversas que podem ser observadas entre cidades componentes de uma mesma concentração geográfica de empresas. Segundo Porter (1998), o estudo desse tipo de organização industrial não permite com que se tenha regra fixa para determinação de seu tamanho, podendo com isso, abranger mais de um município.

Assim começa a ser construído o alicerce sob o qual se desenvolvem os fluxos de informação e valores, que se traduz no plano espacial primordial para o estudo da competitividade das concentrações geográficas de empresas sob 0 enfoque estratégico: a estrutura de sustentação das relações entre as cidades, que determinarão as condicionantes das relações sociais decorrentes e que por sua vez vão influenciar nas relações interempresariais.

Nesse contexto, o estudo da geografia torna possível fazer a identificação de diferentes maneiras de configuração das relações entre cidade e uma determinada região: a relação campo-cidade, a relação capital-província e a relação centroperiferia. Essas relações geram, entre si, uma determinada relação hierárquica. A concepção de que a distância do mercado é o principal fator de organização do território inspirou a construção da chamada teoria dos lugares centrais (Christaller, 1966 apud IPEA, 2001). Uma outra forma de configuração das relações entre cidade e região é, sob a perspectiva espacial, a relação entre capital-província, ou capital-interior. Essa relação traduz a presença de uma relação hierárquica entre cidades, determinadas pela lógica da extração tributária e pelas necessidades da circulação mercantil estabelecidas de forma permanente no território.

Para Marteletto (2005), nesta sociedade contemporânea (descrita pela autora como sendo intensamente complexa, globalizada e informatizada), três dimensões merecem destaque quando se visa estudar a perspectiva de redes inerentes à dinâmica dos movimentos sociais: da sociabilidade, da espacialidade e da 
temporalidade histórica. Essa autora detalha que em relação à sociabilidade, encontram-se as redes "sociais do cotidiano" que se constroem a partir das redes sociais primárias (famílias, círculos de amizades, comunidades, etc.), que são penetradas por redes virtuais (caracterizadas por intersubjetividades oriundas da exposição à mídia ou a intercâmbios por meios eletrônicos), e que em conjunto, vão formando as novas identidades na era da informação. Em relação ao caráter da espacialidade, destaca que esse torna-se especialmente relevante, uma vez que, com as novas tecnologias de informação, os atores coletivos e os movimentos sociais engendram redes que estão continuamente redimensionando seus territórios de influência e ação. Assim, o global penetra no associativismo local, originando um espaço capaz de criar alternativas à globalização desde cima, a partir de iniciativas de resistência da sociedade civil local e de suas redes transnacionais (SCHERERWARREN, 1999).

Scherer-Warren (1999) destaca que a pesquisa sobre a dimensão da espacialidade das ações coletivas precisa, "...buscar os elos e os tipos de redes que dinamizam os fluxos de informação, que desenvolvem solidariedade e estratégias de ação e que negociam alternativas de mudança social."

Segundo Matletetto (2005), as redes sociais surgem como um novo instrumento face aos determinismos institucionais, ressaltando:

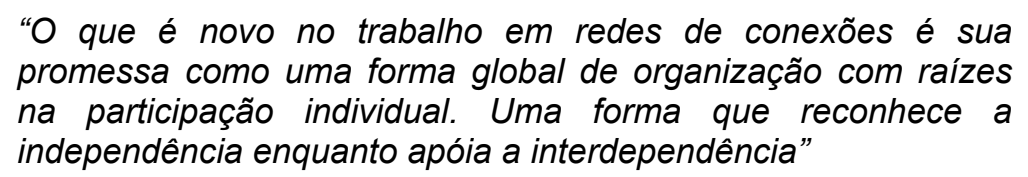

Matletetto (2005),

Essa autora ainda destaca que o estudo das redes evidencia um aspecto social contemporâneo que, ainda está sendo pouco explorado: a percepção de que "os indivíduos, dotados de recursos e capacidades propositivas, organizam suas ações nos próprios espaços políticos em função de socializações e mobilizações suscitadas pelo próprio desenvolvimento das redes". Ainda segundo essa autora, apesar de se originar em uma esfera informal de relações sociais, os efeitos das redes podem ser percebidos fora de seu espaço, seja nas relações interativas com o Estado, distintos setores da sociedade, organizações econômicas (formais ou informais) ou outras instituições representativas. 
Corrêa (1997), baseando-se no conceito de redes dendríticas (que se caracterizam por sua origem colonial, originadas de uma cidade estratégica e localizada excentricamente ao conjunto que polariza, concentrando, nesse centro primaz, as principais funções econômicas e políticas de tal região), verificou a intensa correlação entre renda e densidade da rede urbana. Assim, o fluxo de valor e informações dentro do cluster, passa a se submeter a estrutura maior da rede que define as relações entre as cidades que o compõem.

Também no contexto das redes, pode ser destacado o estudo clássico de Grandori e Soda (1995), que propõem uma tipologia de redes empresarias denominada "Redes Inter-Empresariais" que traz um forte caráter social que se adere prontamente também ao estudo das concentrações geográficas de empresas. Neste estudo os autores utilizam como parâmetros de agrupamento, os graus de formalização das redes constituídas, a centralização e os mecanismos de cooperação que essas podem apresentar. Nessa mesma linha social de pesquisa, Wood Jr. e Zuffo (1996) definem três tipos de estruturas para redes: estrutura modular, estrutura virtual e estrutura livre.

Assim, observa-se que o estudo das redes (tanto de empresas, como sociais) merece destaque no âmbito do estudo estratégico das concentrações geográficas de empresas, na medida em que, assim como destacado por Porter (1998), permite estreitar as teorias das redes, enfocando seus aspectos sociais e culturais, aos resultados competitivos deles decorrentes.

\subsection{AGRONEGÓCIO: CONCEITO E PRINCIPAIS ABORDAGENS}

O termo "agronegócio" tradução do termo "agribusiness" tem sido largamente utilizado nos estudos referentes à organização das cadeias produtivas relacionadas aos negócios agropecuários, muitas vezes relacionando-se a "complexos agroindustriais", "cadeias agroindustriais", "agronegócios", "sistemas agroindustriais", etc.

Para Batalha e Scarpelli (2005), apesar de apresentarem ampla variação quanto aos seus objetivos, métodos e grau de academicismo, a grande maioria 
desses trabalhos buscam compreender a geração e a respectiva distribuição entre os agentes geradores desses valores.

Segundo Zylbersztajn (2000), o conceito de agribusiness foi utilizado pela primeira por vez por Goldberg (1957) e segundo seus proponentes representa a "soma total das operações de produção e distribuição de suprimentos agrícolas, das operações de produção nas unidades agrícolas, do armazenamento, processamento e distribuição dos produtos agrícolas e itens produzidos com base neles". Segundo Batalha e Scarpelli (2005), os autores seguramente se basearam nos conceitos e idéias oriundos da teoria dos sistemas para desenvolver esse conceito.

O caráter sistêmico da abordagem dos agronegócios implica na condição de que exista uma organização dos componentes para que os objetivos comuns do sistema possam ser efetivamente atingidos. Essa abordagem está baseada em três segmentos, concentrados em sua grande maioria nas unidades de produção rural ("da porteira para dentro"), de insumos (máquinas, implementos, defensivos, fertilizantes, sementes, tecnologia, etc) e as atividades dos segmentos concentrados fora das unidades produtivas ("da porteira para fora"), representado pelas atividades de armazenamento, beneficiamento, industrialização, distribuição e consumo (Zylbersztajn 1995). Uma análise mais detalhada dessa visão sistêmica é dada em Shelman (1991). Este sistema agroindustrial seria composto por vários subsistemas agroindustriais associados aos principais produtos e envolve ainda, órgãos de coordenação, os mercados e serviços de apoio como créditos, mão-de-obra, transporte, energia, etc. (Goldberg 1968, apud ZYLBERSZTAJN, 2000)

O trabalho de Davis e Goldberg (1957) é considerado um marco no estudo das atividades de produção e comercialização agropecuária, sendo o primeiro estudo que introduziu a abordagem desse negócio como um processo de transformação e adição de valor a commodities agrícolas, desde a indústria de insumos até o consumidor final (NUNES: CONTINI, 2001). Posteriormente, Goldberg adota um conceito mais amplo, denominado Commodity System Aprpoach (CSA), que traz como base, um determinado produto dando origem a vários outros (Goldberg 1968 apud BATALHA; SCARPELLI, 2005).

Paralelamente aos estudos de Davis e Goldberg, a escola francesa de economia industrial propunha uma abordagem distinta (filiére), onde havia dois focos de análise: um determinado por um produto final e outro determinado por uma matéria prima de base (BATALHA;SCARPELLI, 2005; NEVES et al. 2002). Para 
Batalha e Scarpelli (2005) a análise em função de um determinado produto, por ter um caráter mais restrito de abrangência é mais apropriada ao estudo da competitividade das empresas envolvidas "e por conseqüência, é importante como espaço de análise externa das ações estratégicas dessas mesmas firmas". Os autores destacam que tal o espaço de análise desse tipo de abordagem é comumente denominado como "cadeia agroindustrial".

A análise desenvolvida sob o enfoque do conjunto de várias cadeias agroindustriais relacionadas a produtos de base, segundo Batalha e Scarpelli (2005) vem sido comumente utilizado com a denominação de "Complexo Agroindústrial". Esses autores destacam que a análise sob esse enfoque, por ser mais amplo do que o enfoque em função do produto, tem seu maior significado pra o estudo das estratégias corporativas das empresas envolvidas e especialmente no que se refere aos estudos relacionados a políticas públicas setoriais.

Para Farina e Zylbersztajn (1992) existe a necessidade de diferenciar a noção de complexo daquela vinculada ao sistema agroalimentar e destacam que, "... um complexo é definido pela força de suas relações tecnológicas, a noção de sistema abriga uma idéia de organizacidade na busca de um resultado." Batalha e Scarpelli (2005) alertam que no caso desse tipo de abordagem, há necessidade da definição clara dos limites de abrangência considerado, dado pela descrição clara do ambiente de análise dos produtos considerados, matérias-primas e operações envolvidas. Esses autores destacam que esse termo, por se apresentar menos específico dos que os anteriormente tratados "pode ser aplicado a qualquer recorte das atividades do agronegócio, desde que seja devidamente qualificado". Aliás, para esses autores, essa mesma lógica é aplicada ao conceito de agronegócio, ou seja, deve ser sempre empregado quando devidamente qualificado.

A idéia de organização sistemática presente nos sistemas agroindustriais (FARINA; ZYLBERSZTAJN, 1992) e descrição de sistema agroindustrial, realizada por Neves et al. (1997), permitem maior clareza e segurança na realização de estudos capazes de trazerem uma clara identificação dos pontos fortes e fragilidades de uma dada cadeia produtiva e com isso identificar os fatores que possam estar prejudicando ou beneficiando esta cadeia como um todo.

Farina e Zylbersztajn (1992) afirmam que a dinâmica dos sistemas agroindustriais também é determinada, pela forma de organização das cadeias, sendo que a sua organização, determina a forma de distribuição das atividades entre 
as firmas e como estas se relacionam. Assim, o desempenho de um determinado elo da cadeia é influenciado pelo desempenho dos demais. Isso faz com que as relações entre os elos de uma determinada cadeia assumam papéis importantes quando se visa a análise estratégica.

Nem sempre, as cadeias produtivas estão restritas a uma mesma localidade delimitada por critérios sociais, políticos ou geográficos naturais. Geralmente, as cadeias de produção transpõem esses limites, e passam a abranger áreas distintas. Como cada área possui suas especificidade em termos culturais, políticos, sociais, etc, tanto a análise do ambiente competitivo quanto o estabelecimento de ações para uma determinada cadeia produtiva que abranja localidades com tais diferenças, devem considerar prioritariamente esses aspectos.

Sob a análise sistêmica apresentada por Davis e Goldberg (1957) apud Zylbersztajn (1995), considera-se o agronegócio de flores no Brasil como sendo o conjunto de todas as atividades de produção, preparo, distribuição e aquisição dos produtos relacionados a floricultura. Em seu sentido mais amplo, a floricultura engloba além do cultivo de flores para corte, a produção de folhagens, mudas e plantas arbóreas de pequeno e grande porte (CASTRO, 1988; COSTA: CAIXETA FILHO, 2002; Francisco et al. 2003a). Assim, a abordagem sob o enfoque da cadeia produtiva fica comprometida quando não se define ao certo o produto oriundo dessa cadeia.

Segundo abordagem de Batalha e Scarpelli (2005) torna-se necessário a definição da flor ou planta ornamental que especificamente é produzida na cadeia. $O$ mesmo raciocínio também é valido para a abordagem sob a ótica do complexo agroindustrial o que impede também que se faça uma abordagem considerando-se um "complexo agroindustrial de flores e plantas ornamentais". Assim, a abordagem sob o enfoque do "sistema agroindustrial de flores e plantas ornamentais", seguindo as considerações de Batalha e Scarpelli (2005), torna-se a mais apropriada ao objeto do presente estudo. 


\subsection{ESTRATÉGIA COMPETITIVA}

\subsubsection{Estratégia no Contexto Empresarial}

A palavra "estratégia" é um termo militar, cuja origem vem do termo grego "stratego" que significa "a arte do generalato" (CARVALHO; LAURINDO, 2003). O estudo da estratégia, tem sua origem, ainda no Século IV a C, através do estudioso militar chinês, Sun Tzu, seu principal representante. Sua influência foi particularmente importante sobre-os autores que buscam roteiros e declarações de princípios voltados à estratégia de negócios, especificamente aqueles que deram origem à escola de pensamento estratégico chamada "escola do posicionamento" de 1980 (CARVALHO; LAURINDO, 2003).

No dicionário, estratégia é definida como "a arte de aplicar os meios disponíveis com vista à consecução de objetivos específicos, arte de explorar condições favoráveis com o fim de alcançar objetivos específicos." (FERREIRA 1975)

Na obra de Carvalho e Laurindo (2003) os autores fazem um estudo detalhado sobre a evolução histórica da estratégia militar e sua posterior aplicação ao contexto empresarial. Nessa obra, os autores destacam a importância de dois generais: Karl von Clausewitz (1780-1831) e Antoine-Henri Dejomini (1779-1869), que através dos estudos dos sucessos napoleônicos, desenvolveram duas diferentes formas de abordagem da estratégia militar. Para Von Clausewitz a teoria da estratégia deveria ter um caráter descritivo, ou seja, não haveria uma "receita" para o sucesso estratégico, mas seria possível aprender observando as experiências alheias. Para esse estudioso, o enfoque descritivo, auxiliaria na formação do julgamento e intuição dos comandantes, mas não poderia ser usado como fundamentos para ação. Já para o general Henri Dejomini, haveria princípios científicos para a estratégia militar que não só poderiam ser prescritos, mas que deveriam ser deveriam ser seguidos, criando assim um enfoque prescritivo. Esses dois militares influenciaram o surgimento de correntes de pensamento estratégico voltadas para o mundo dos negócios: a corrente descritiva e a corrente prescritiva (CARVALHO; LAURINDO, 2003). 
A importância desses dois generais para o estudo da estratégia no campo empresarial pode também ser observada na obra de Henry Mintzberg, Joseph Lampel e Bruce Ahlstrand, intitulada "Safári de Estratégias". Neste livro, em nove capítulos, os autores organizam as principais escolas do pensamento estratégico no ambiente empresarial: design, planejamento, posicionamento, empreendedorismo, cognitiva, aprendizado, poder, cultural, ambiental e configural. As escolas do design, do planejamento e do posicionamento estariam relacionadas à linha analítica e prescritiva uma vez que relacionam o sucesso da estratégia a análise prévia da organização e do ambiente a qual a mesma esteja inserida. Nessa análise, são considerados os pontos fortes e pontos fracos da organização em função das ameaças e das oportunidades impostas pelo ambiente de mercado. Já as demais escolas estariam relacionados a abordagem prescritiva.

A influencia militar no pensamento estratégico empresarial é também destacada por Nakamura (1999), que relaciona o ambiente competitivo, como um ambiente de guerra, onde cada empresa tem em seus recursos a representação maior de seus exércitos e em seus concorrentes a representação maior de seus inimigos. Tanto no campo militar quanto no campo empresarial, a estratégia é analisada genericamente sob três aspectos: operacional, tático e estratégico, onde o aspecto estratégico se relaciona às questões de âmbito mais genérico, de mais longo prazo (ALBUQUERQUE; DA SILVA, 2002)

Motta (1991), situa bem a questão da importância da estratégia empresarial e faz uma abordagem cronológica da evolução desse tema no contexto empresarial, identificando três fases:

a) A primeira fase, nos anos de 1950, foi fundamentada na formulação estratégica, quando esse conceito começou a ser empregado visando responder a um inicio de um longo processo de mudança das relações competitivas, onde a visão de futuro, passava ganhar espaço. Tinha-se então, um início efetivo da aplicação do conceito de estratégia empresarial, onde o foco era a visão de maior escopo e mais longo prazo através de métodos analíticos, com possibilidades maiores de previsão do futuro.

b) A segunda fase foi na década de 1960, quando segundo o autor, o conceito de estratégia se popularizou. As mudanças do ambiente competitivo estavam mais intensas, e as análises de antes, não mais 
conseguiam responder às mudanças de cenário do futuro. Era necessário o aperfeiçoamento dos métodos então desenvolvidos na fase anterior e com isso, nascia, o que o autor chamou de "período do Planejamento Estratégico“.

c) A terceira fase, denominada pelo autor como sendo o "período da gerência estratégica" teve inicio na década de 1970. Nesta fase, iniciase o processo de consolidação do pensamento estratégico na área empresarial. Segundo o autor, é nesta fase em que as idéias da fase anterior, baseadas num planejamento contínuo e influenciado constantemente pela inovação, congrega a maior efetividade de suas ações e propósitos.

Para Ansoff (1977) a estratégia enfatiza a análise racional em termos de alta cúpula da empresa, em que os objetivos são essenciais na orientação, avaliação de desempenho e na consecução dos propósitos organizacionais, os quais devem ser coerentes com seu "perfil de potencialidades". Tal abordagem ressalta um caráter prescritivo de gerenciamento estratégico voltado à definição de diretrizes específicas. Nessa linha prescritiva, Quinn (1992), ressalta que a estratégia é um plano que integra metas maiores, políticas e seqüências de ações, dentro de um todo coeso que se bem formulada e aplicada, ajuda a ordenar e alocar os recursos, permitindo a antecipação de alterações no ambiente competitivo.

Mintzberg (1992), apresenta uma abordagem que pode ter a estratégia como plano, como manobra (ploy), como padrão, como posição e como perspectiva. Na abordagem como "plano" destaca o estabelecimento de diretrizes para um curso de ação apresentando nesse contexto, um caráter amplamente prescritivo. Já na abordagem da "manobra" (ploy), a estratégia é encarada como um meio de ganhar vantagem sobre a concorrência. A abordagem da estratégia como um padrão de ações a serem seguidas, é baseada num fluxo de ações, apresentando um caráter já muito mais descritivo. Já na abordagem da estratégia como posição, o principal enfoque é a localização da organização no ambiente, mediando forças num ambiente de contexto interno e externo, neste caso, apresentando um caráter muito mais representativo da escola do posicionamento. A abordagem como "perspectiva" é voltada para o interior da organização, não como uma posição escolhida, mas como uma forma consolidada desta enxergar o ambiente externo. 
Para Porter (1996) a estratégia no contexto empresarial, corresponde à criação de uma única e valiosa posição, envolvendo um diferente grupo de atividades.

Slack et al.(2002) entendem a estratégia empresarial como sendo "um padrão global de decisões e ações que posicionam a organização em seu ambiente e tem o propósito de fazê-la atingir seus objetivos de longo prazo". O caráter de longo prazo e de posicionamento destacado por esses autores é congruente as idéias apresentadas por Carvalho e Laurindo (2003), Mintzberg (1992) e Mintzberg e Quinn (2001).

A análise da literatura mostra, em termos gerais que, mesmo se diferenciando pela ênfase e um ou outro aspecto do ambiente dos negócios, as definições de estratégia, via de regra, se encontram relacionadas à ligação da empresa com o seu ambiente e contemplam, principalmente, o estabelecimento de métodos e planos de ação pra atingir os objetivos da organização (ALBUQUERQUE; SILVA, 2002). É possível também observar nessas abordagens, a importância dos estudos de Karl von Clausewitz (1780-1831) e do general franco-suíço Antoine-Henri Dejomin (apontados por Carvalho e Laurindo, 2003), onde podem ser observados tanto o caráter descritivo como prescritivo.

As definições até então apresentadas são capazes de representar a importância da estratégia para a organização, na medida em que essa se apresenta além da necessidade básica de manter seu potencial competitivo, assegurando um caráter orientador aos seus diversos componentes.

Baseando-se nos conceitos ora apresentados e nas diferenciações em termos genéricos entre esses conceitos, pode-se dizer que a estratégia empresarial se encontra associada à adoção de um conjunto de atividades capazes de uma posição única e exclusiva para uma organização, permitindo que essa venha a se colocar no cenário competitivo de maneira superior e diferenciada de seus concorrentes. 


\subsubsection{Competitividade}

O estudo da estratégia empresarial está intimamente relacionado à busca pela competitividade, traduzida na busca de uma vantagem que viabilize o alcance dos objetivos competitivos da organização.A literatura acadêmica apresenta diferentes conceitos de competitividade, dependendo da finalidade com que os trabalhos são realizados.

Esses diferentes conceitos implicam, segundo Jank (1996), em diferentes formas de investigação e mensuração dos aspectos relacionados a esse tema, onde alguns identificam um grupo de indicadores associados que diferem pelo modo de análise, pelo direcionamento face à área de atuação e pela motivação em sua construção. Esses indicadores contemplam os mais diversos tipos de variáveis e critérios.

Jank (1996) ainda relata que os conceitos mais amplos são aqueles que se referem à sociedade como um todo e se baseiam essencialmente na questão do bem estar dos cidadãos. Ainda para esse autor, "é imprescindível que a discussão sobre competitividade seja qualificada nos diferentes níveis de análise possíveis: nação, setor econômico ou firmas individuais".

Ferraz et al. (1997) identificam duas vertentes diferentes de entendimento do conceito de competitividade: desempenho e eficiência. $\mathrm{Na}$ primeira delas a competitividade é vista como um "desempenho" de uma empresa ou produto. Nesse caso, os resultados das análises traduzem-se na determinação de uma dada competitividade revelada, cujo principal indicador, segundo essa ótica de entendimento, estaria ligada à participação de um produto ou empresa em um determinado mercado ("market share"). Ainda sob a ótica do "desempenho", esses autores abordam a competitividade de uma nação ou setor como sendo o resultado da competitividade individual dos agentes que o compõem. Sob o foco da "eficiência", os autores relacionam ao potencial de competitividade de um dado setor ou empresa, que poderia ser realizado por meio da identificação e estudo das opções estratégicas adotadas pelos agentes econômicos, face as suas restrições gerenciais, financeiras, tecnológicas, organizacionais, etc.

Segundo Porter (1998) a idéia de que a competitividade tem como seus determinantes mais poderosos os custos de mão-de-obra, as taxas de juros e de 
câmbio e as economias de escala, não garantem a sustentabilidade. Esse autor se mostra um efetivo critico a idéia de que esses fatores associados a outros fatores de produção (como recursos naturais, capital e infra-estrutura) sejam determinantes na competitividade de uma dada localidade. Isso, segundo o autor, pode ter sido verdadeiro por um longo período da história econômica do Homem, quando de maneira geral, o cenário era mantido por um desenvolvimento tecnológico equivalente. No entanto, Porter (1993), mostra que a consolidação do caráter transacional das empresas, permitiu a elas, através de suas estratégias globais ou da tecnologia, o acesso a esses fatores, oferecendo produtos mundiais que trazem componentes e/ou a possibilidade de serem montados em diferentes partes do Globo. Esse posicionamento critico fica bastante evidenciado nas seguintes palavras do autor:

"... essa teoria, cujas origens remontam de Adam Smith e David Ricardo e que impregna a economia clássica é na melhor das hipóteses incompleta e na pior das hipóteses incorreta"

Porter (1993)

Para Porter (1990) os fatores de produção mais importantes, no contexto atual da competitividade global, capazes de gerar uma vantagem competitiva moderna, são altamente especializados para a necessidade do setor e envolvem grandes investimentos. Assim, a geração desses fatores passa a ser um aspecto essencial para a criação das vantagens competitivas capazes de sustentar um setor, uma localidade ou uma nação. O autor exemplifica seu posicionamento, relatando a presença na Holanda de institutos de pesquisa em embalagens, cultivo e exportação de flores, tidos como referência e que sustentam o status holandês de ser um grande exportador de flores em nível mundial.

No contexto dos agronegócios brasileiros, a consistência da proposição desse autor pode ser verificada com clareza, ao se considerar a existência de diversas instituições referência, tanto em nível nacional como em nível global, das quais podem ser destacadas a EMBRAPA (Empresa Brasileira de Pesquisa Agropecuária) ligada ao Governo Federal, o IAC (Instituto Agronômico de Campinas) e o IEA (Instituto de Economia Agrícola) ligados ao governo estadual paulista, O IAPAR 
(Instituto Agronômico do Paraná) ligado ao governo estadual paranaense, as Universidades estaduais paulistas e as Federais de Viçosa (MG), Lavras (MG), Santa Maria (RS) e Mossoró (RN), entre outras, que certamente apresentam significativa participação nos resultados positivos da economia ligada aos agronegócios brasileiros.

No contexto do presente estudo, focado na análise estratégica das concentrações geográficas de empresas, a abordagem territorial da competitividade torna-se necessária, na medida em que o enfoque aqui abordado, tanto se relaciona ao caráter individual das empresas como também ao aspecto da competitividade conjunta da concentração geográfica considerada. Passa-se então a considerar de maneira efetiva, que o conceito de competitividade pode estar assim associado tanto a um país, como a uma localidade.

Farina e Zylbersztajn (1992), reforçam o caráter regional do conceito de competitividade, afirmando que, a esse conceito, deve ser acrescido da definição de competitividade regional, uma vez que o desempenho individual das empresas depende de relações sistêmicas presentes no ambiente onde essa se localiza.

A competitividade regional, assim considerada, traz como elementos centrais conceitos fortemente relacionados a uma interação sinérgica entre as empresas de uma dada concentração geográfica de empresas e entre elas e seu aparato institucional. Tanto a questão da inter-relação sinérgica quanto às questões relacionadas à infra-estrutura, são fundamentais para a promoção e crescimento de uma determinada região ou localidade. Nesse contexto, as concentrações geográficas de empresas, alvo de presente estudo, se inserem plenamente nos conceitos apresentados nessas abordagens.

Para finalizar, pode-se dizer que nesse trabalho, a exemplo de outros autores, considera-se a competitividade como sendo a capacidade de se obter rentabilidade e manter participação de mercado no âmbito interno e externo (mercado internacional), de maneira sustentada. 


\subsubsection{Análise Ambiental no Contexto da Estratégia Empresarial}

A dinâmica das mudanças no ambiente competitivo das empresas começou a se mostrar mais intensa a partir de meados de 1960, quando essas se viram obrigadas a responder com maior rapidez a essas mudanças, na tentativa de se manterem competitivas em seu mercado de atuação. Nessa época a ênfase dos estudos relacionados a gestão empresarial, estava fundamentalmente voltada para questões mais pontuais, como marketing, produção e finanças.

Não obstante, a preocupação com o meio externo e o desenvolvimento da visão estratégica nas empresas, começou a ganhar força através da abordagem teórica da "Ecologia de Empresas", onde o foco é a relação das empresas com o mundo externo (CAVALCANTI, 1986).

O mundo externo também foi foco dos estudos de Andrews e Christensen, dois pesquisadores da Harvard Business School, que passaram a associar a análise externa do ambiente aos aspectos internos da organização, através da identificação dos pontos dos pontos fracos e fortes da organização, confrontando-as às com as oportunidades e ameaças do ambiente externo (MONTGOMERY; PORTER, 1988).

Trazendo uma forte relação com o trabalho desenvolvido por esses autores, Porter (1991) desenvolveu um referencial analítico para o desenvolvimento de estratégia nas organizações, embasada na estrutura setorial do negócio e na vantagem competitiva buscada. Mais tarde esse mesmo autor desenvolveu outros trabalhos que vieram a detalhar e subsidiar esse referencial, dos quais dois, se relacionam especificamente ao estudo da estratégia empresarial (PORTER,1996) e a concentração geográfica de empresas (PORTER, 1998).

\subsubsection{Análise do Ambiente Externo}

A análise do ambiente externo teve em Michel Porter, um de seus mais expressivos representantes. Para esse autor "a essência da formulação estratégica consiste em enfrentar a competição" que para esse autor, se encontra estruturada sobre dois pilares: a atratividade das indústrias e os fatores determinantes do 
posicionamento competitivo dentro dessa mesma indústria (PORTER, 1991). Nesse contexto, a essência da formulação da estratégia fica condicionada a resultante das cinco forças competitivas, que segundo o autor, exercem pressão sobre a empresa e com isso, acabam por imprimir a atratividade da indústria: a ameaça de entrada de novos concorrentes, a ameaça de substitutos, o poder de negociação dos compradores, o poder de negociação dos fornecedores e a rivalidade entre os concorrentes (PORTER,1991). Na análise das forças competitivas, Porter (1991) enfatiza que todas as cinco forças, é que vão determinar a intensidade competitiva de uma dada indústria e sua rentabilidade, no entanto, o autor destaca que a(s) força(s) mais acentuadas são determinantes na formulação das estratégias. Quanto melhor equacionar as resultantes dessas forças forem ao favor da empresa, maiores as oportunidades para a obtenção de um desempenho superior aos concorrentes.

Especificamente relacionado ao estudo das concentrações geográficas de empresas, a ameaça de novos entrantes assume grande importância, na medida em que a própria dinâmica da concentração pode determinar uma maior ou menor intensidade a cada uma dessas barreiras. Esse tipo de ambiente pode também minimizar os efeitos relativos quanto à ação dos concorrentes já existentes, na medida em que seu maior nível de organização e relacionamento local, podem influenciar as ações que passam a repelir os novos entrantes. (PORTER, 1998),

Além dessas forças competitivas, Porter (1993) analisa o papel do governo como sendo uma força que pode atuar em todas as cinco forças destacadas, mostrando que nenhuma analise estrutural é correta se não levar em conta o papel do Estado sobre cada uma dessas forças.

A análise ambiental torna-se assim, fator de extrema importância no estudo das concentrações geográficas de empresas, na medida em que essas podem, através de sua própria dinâmica interna, e através das relações existentes em seu meio, alterar as relações de forças de uma determinada indústria. 


\subsubsection{Análise do Ambiente Interno}

A análise do ambiente interno às organizações está intimamente relacionada ao desenvolvimento das competências organizacionais necessárias para garantir seu bom desempenho, seja ele em termos operacionais ou em termos competitivos.

Inicialmente, o estudo das competências estava mais relacionado às habilidades necessárias ao trabalhador para garantir o bom desempenho de suas tarefas (LAWER,1994). Isso é contestado por Dunphy et al.(1997) que defendem a tese de que tais competências são resultantes da combinação de habilidades com conhecimento.

Uma das mais importantes abordagens desse assunto foi feita por Prahalad e Hammel (1990), que desenvolveram o conceito das "competências essenciais", que para esses autores, representa o aprendizado coletivo da organização. Neste estudo os autores se baseiam no problema de identificação do núcleo dessas competências e que essas podem ser gerenciadas através de cinco dimensões: o desenvolvimento dessas competências ao longo de tempo; a disseminação dessas competências na organização; a integração das diversas competências desenvolvidas traduzidas em resultados organizacionais; a necessidade de balanceamento das competências existentes e o processo de renovação dessas competências.

"(...) a conexão tangível entre competências essenciais identificadas e produtos finais são os produtos essenciais - a materialização física de uma ou mais competências essenciais (...) são os componentes ou sub-nidades que realmente contribuem para o valor dos produtos finais."

Prahalad e Hammel (1990)

Drejer (2001) destaca que a instabilidade dinâmica do ambiente competitivo impõe a necessidade de que as empresas desenvolvam constantemente suas habilidades e competências, sendo então necessária à elaboração de um sistema para medição da melhoria e desenvolvimento dessas competências. Assim, o autor propõe a abordagem das competências com sendo a relação entre tecnologia, pessoas, estrutura e cultura organizacional, para que possa ser discutida sob seu aspecto estrutural. Essa é a grande crítica que esse autor faz ao modelo de 
Prahalad e Hammel (1990), pois segundo Drejer (2001), esse modelo é baseado na definição das competências essenciais em função das características funcionais das competências e não nas estruturais.

Outros estudos, como os de Prahalad e Ramaswany (2000) e Awauh (2001) mostram a importância das redes de empresas como meio para desenvolvimento das competências essenciais, principalmente se a dinâmica imprevisível do ambiente competitivo for considerada. Esses estudos mostram como a dinâmica inter-organizacional se relaciona a dinâmica intra-organzacional de formação das competências necessárias a garantia da competitividade empresarial.

Neste contexto, a análise do ambiente interno das organizações e suas condicionantes estratégicas, no âmbito do estudo das concentrações geográficas de empresas, assume caráter relevante, na medida em que através dessa análise torna-se possível identificar oportunidades de interação estratégica com outros aspectos importantes geradores das vantagens competitivas, como por exemplo, as ações conjuntas, que podem ter papel direto no desenvolvimento dessas competências.

\subsection{CADEIA DE VALOR E GOVERNANÇA}

O termo "cadeia de valor" foi definido por Porter e Millar (1985) como sendo o conjunto de várias atividades seqüenciais, necessárias para o desenvolvimento de um determinado produto e/ou serviço. Esse conceito baseado numa visão detalhada e sistemática das operações desenvolvidas em uma organização, permite determinar a participação de cada uma dessas operações na atribuição do valor do produto, que é dado pelo cliente.

O conceito apresentado por esses autores possibilita dois níveis de análise nas relações existentes entre os atores dessas cadeias: as relações verticais (entre produtores e compradores) e as relações horizontais (entre os atores e entre os atores com as instituições locais). As relações de poder originadas nessa estrutura remetem ao conceito de governança. Para Williamson (1895), as relações de governança em um dado ambiente organizacional está condicionada as influencias 
do ambiente institucional e dos atores econômicos a que as empresas estejam relacionadas.

A relevância do enfoque das cadeias de valor e governança nos estudos referentes às concentrações geográficas de empresas e especialmente, aquelas voltadas para os agronegócios, pode ser encontrada nos trabalhos de Jank (1996) e Porter (1993), respectivamente. Para Porter (1993) a coordenação das atividades assume, juntamente com a pressão pela inovação, um caráter decisivo na geração da qualidade e da eficiência nas concentrações geográficas de empresas. Com relação ao estudo dos agronegócios, Jank (1996) argumenta que qualquer modelo metodológico e conceitual que se pretenda adequado para a análise de competitividade em agronegócios deve, necessariamente levar em consideração os ganhos potenciais de uma coordenação eficiente da cadeia.

\subsubsection{Cadeia de Valor e Sistema de Valor}

O conceito apresentado por Porter e Millar (1985), baseado nas atividades desenvolvidas por uma dada organização é segundo esses autores, fundamentado em dois grupos de atividades: atividades-meio (infra-estrutura organizacional, recursos humanos, compra de insumos e tecnologia) e atividades fim (logística interna e externa, marketing, vendas e prestação de serviços). Nessa abordagem, uma organização se torna mais competitiva que a outra na medida em que consegue uma maior agregação de valor no desenvolvimento de suas atividades, quando comparada aos seus concorrentes.

Segundo Porter (1990), num determinado setor industrial, as diferenças entre as cadeias de valor concorrentes é que vão determinar as vantagens competitivas geradas. Para esse autor, o conceito de valor compreende o quanto os compradores estão dispostos a pagar e assim, a rentabilidade deve ser dada pela diferença entre o custo gerado para produção de um determinado bem (ou prestação de um dado serviço) em relação ao valor por ele alcançado. Tal abordagem justifica a análise competitiva defendida por esse autor, feita em função do valor criado num determinado sistema. 
Com o desenvolvimento do caráter globalizado da economia mundial, vários autores passaram a tratar esse conceito sob o enfoque das cadeias globais de produção ou cadeias globais de valor.

Com a intensificação das relações entre empresas de deferentes países acabou por gerar condições especificas em que decisões estratégicas relacionadas à produção e/ou desenvolvimento de determinados bens e/ou serviços são tomadas por agentes muito distantes do local de onde esses bens e/ou serviços dão gerados.

Para Porter (1990) a sustentação de uma determinada vantagem competitiva, vai além da cadeia de valores. Vai depender também do modo como a empresa se enquadra num sistema mais amplo ("sistema de valor"), que engloba a cadeia de valor de uma determinada indústria, desde os fornecedores até o cliente final.

Nesse contexto, os estudos voltados à estratégia competitiva dos negócios, não podem estar voltados à análise exclusiva de uma organização como se a sua inter-relação com seus clientes, instituições locais e fornecedores não apresentasse influencias importantes. Segundo Relvas (1996), uma empresa não agrega valor somente pelo processamento e/ou combinação de recursos, mas também pela rede que estabelece envolvendo os atores internos e externos desse cenário.

\subsubsection{Governança}

O termo "governança" é utilizado nos estudos referentes aos processos de coordenação dos agentes de um determinado sistema produtivo, em suas várias esferas de relacionamento (entre os setores públicos e privados, em níveis local, regional ou global). O estudo dessas relações torna-se importante uma vez que essas influenciam no desempenho das organizações, que pode ser refletido também nos agrupamentos produtivos em que essas possam estar inseridas.

Humphrey e Schmitz, (2000), elaboraram minucioso estudo bibliográfico e identificaram três tipos básicos de governança, por eles denominados: governança de redes (ou quasi-hierarquica), mercado e hierárquica (ou vertical). O Quadro 2.1, adaptado desse estudo, resume com clareza essas relações. 
O estudo dessas relações torna-se importante uma vez que essas influenciam no desempenho das organizações, que pode ser refletido também nos agrupamentos produtivos em que essas possam estar inseridas.

Posteriormente, num outro estudo (HUMPHREY: SCHMITZ, 2001), esses autores apresentaram um quadro comparativo entre os tipos de governança identificados por eles e por outros dois autores, conforme pode ser observado no Quadro 2.2

Quadro 2.1 Categorias de ações pública - privadas e níveis de governança localglobal das atividades econômicas (adaptado de Humphrey e Schmitz,2000)

\begin{tabular}{ccc}
\hline & Nível local & Nível Global \\
\hline Governança privada & $\begin{array}{c}\text { Associações locais de } \\
\text { negócios }\end{array}$ & $\begin{array}{c}\text { Cadeia do comprador } \\
\text { global }\end{array}$ \\
$\begin{array}{c}\text { Governança pública } \\
\text { Governança pública- } \\
\text { privada }\end{array}$ & $\begin{array}{c}\text { Rede de políticas } \\
\text { locais e regionais }\end{array}$ & $\begin{array}{c}\text { Regras nacionais e } \\
\text { internacionais com } \\
\text { padrão global }\end{array}$ \\
& regionais e locais & Padrões internacionais \\
\hline
\end{tabular}

Segundo Gereffi (1999), quando o comprador exerce um certo controle sobre a cadeia, determinando regras para atuação dos outros atores, se estabelece um tipo de governança denominada "buyer driven". Este tipo de governança pode ser observado no estudo de Dolan e Humphrey (2000), onde os autores puderam observar que os varejistas ingleses são os responsáveis pela determinação de certas regras de comercialização para a cadeia de vegetais frescos na África do Sul, definindo o número de fornecedores, seus sistemas de qualidade e procedimentos para monitorar a performance.

Outro tipo de comportamento, apresentado no mesmo trabalho de Gereffi (1999), ocorre quando os agentes produtores ditam as regras para outras agentes ao longo da cadeia, à exemplo do que ocorre nas cadeias automotivas. Nesse caso, os autores denominaram essa relação de governança de "producer-driven". 
Quadro 2.2 Tipos de governança identificados por diferentes autores (adaptado de Humphrey e Schmitz, 2001)

\begin{tabular}{|c|c|c|c|}
\hline AUTOR & $\begin{array}{l}\text { Jessop } \\
\text { (1998) }\end{array}$ & $\begin{array}{c}\text { Williamson } \\
\text { (1979) }\end{array}$ & $\begin{array}{c}\text { Humphrey e } \\
\text { Schmitz (2000) }\end{array}$ \\
\hline \multirow[t]{3}{*}{ Governança } & Anárquica & Mercado & Mercado \\
\hline & Auto-organização & Redes & $\begin{array}{l}\text { Redes / Quasi- } \\
\text { hierárquica }\end{array}$ \\
\hline & Hierárquica & $\begin{array}{l}\text { Integração } \\
\text { Vertical }\end{array}$ & Hierárquica \\
\hline
\end{tabular}

\subsection{CONCLUSÃO: ESTRUTURA ANALÍTICA}

Com o intuito de organizar as etapas seguintes da pesquisa, foi desenvolvida uma estrutura teórico-conceitual, que envolvesse os principais aspectos discutidos no ambiente acadêmico, no que concerne à criação de vantagens competitivas de uma dada concentração geográfica e setorial de empresas e os fatores relevantes para catalisar as ações conjuntas de cooperação, bem como as possíveis perspectivas de estudo que à este tema podem estar associadas.

Apesar da literatura investigada apresentar perspectivas por vezes distintas de áreas temáticas, esses estudos trazem consigo a convergência do recorte geográfico e setorial.

Alguns estudos são desenvolvidos sob um contexto mais amplo de abordagem, voltados a investigar a influencia desse tipo concentração na promoção do desenvolvimento socioeconômico de países ou regiões enquanto outros, procuraram investigar o papel dos agentes de governo e suas relações com os atores de uma determinada concentração.

Existem trabalhos na literatura que apresentam uma perspectiva mais pontual, voltados à investigação dos efeitos que esse tipo de arranjo industrial possa exercer sobre a formação das competências locais, eficiência coletiva, como elementos estruturais na construção das vantagens competitivas dessas concentrações. Outros também apresentando essa abordagem mais pontual, 
buscam investigar o nível e a intensidade das relações intra e inter-organizacionais, seus efeitos e relações na da cadeia produtiva.

Com isso, a estrutura analítica aqui proposta fica condicionada aos limites impostos pelas escopo desta pesquisa, ou seja: ambientes agroindustriais geograficamente determinados e com a presença significativa de unidades agrícolas de produção de um mesmo setor, presença de empresas de apoio não diretamente relacionadas à produção e a presença de entidades de representativas da organização de produtores que atuem diretamente no desempenho das atividades de produção (dentro da porteira).

A presente estrutura é baseada em cinco blocos de fatores que congregariam os elementos identificados nas diversas abordagens, estruturados segundo os objetivos desta tese, conforme síntese apresentada no Quadro 2.3. Os blocos de análise são: Bloco "Cooperação e Parceria"; Bloco "Localidade"; Bloco "Cooperativismo e Associativismo" ; Bloco "Inovação e Informações"; Bloco "Gestão e Estratégias". A fundamentação teórica e a abordagem dos principais fatores relatados neste capítulo estão esquematizadas nesse mesmo Quadro 2.3 e a descrição dos objetivos específicos e a estrutura de cada bloco está descrita a seguir:

Bloco "Cooperação e Parceria": está relacionado prioritariamente a abordagem do ambiente organizacional, sob a ótica da investigação do nível e intensidade das relações intra e inter-organizacionais dentro da concentração geográfica estudada, bem como os efeitos desse processo no desenvolvimento de competências específicas e da eficiência coletiva. A analise institucional, ficou restrita a consideração de fatores como a identidade étnica, histórico de relacionamentos, entre outros, como elementos que podem influenciar no estabelecimento das ações conjuntas e seus reflexos

Bloco "Localidade": orienta-se especificamente a investigar o efeito da localidade (o aspecto territorial geográfico) sobre os resultados dos negócios nela desenvolvidos e sua relação com as externalidades incidentais locais. Para tanto, priorizou-se a investigação sobre a geração de conhecimento na localidade, o papel do poder público local, a percepção por parte dos atores desta localidade quanto a principal competência ali estabelecida e quanto as vantagens e/ou desvantagens proporcionadas pela localidade. 
Bloco "Cooperativismo e Associativismo": foi constituído com vistas a investigar o papel e seus conseqüentes resultados, que as formas de organização dos produtores rurais (cooperativas e associações) podem apresentar na construção das vantagens competitivas da localidade. Nesse sentido, esse bloco buscou avaliar o nível de organização dos principais agentes locais e seus reflexos na estrutura de produção, comercialização e condução dos negócios locais. A presença de cooperativas e/ou associações de produtores rurais é largamente discutida na literatura acadêmica, como agentes promotores do perfil competitivo desses produtores. O papel exercido por essas organizações, tanto nas atividades de produção como de comercialização, faz desse um bloco intimamente relacionado à investigação da estrutura de governança da localidade. Além de atuar nos processo de produção e comercialização, esse tipo de organização também é importante no sentido de promover a aproximação entre os sócios cooperados, promoção de atividades voltadas ao aperfeiçoamento tecnológico e gerencial, dentre outras. Assim, esse bloco traz também forte interação com os fatores relacionados ao desenvolvimento de ações conjuntas e lou cooperativas, uma vez que essas c podem ser significativamente influenciadas pelo papel exercido pelas cooperativas e/ou associações.

Bloco "Inovação e Informações": foi organizado, tendo-se como base o destacado papel da inovação como agente promotor das vantagens competitivas das concentrações geográficas e setoriais de empresas. De maneira geral, as inovações desenvolvidas no âmbito dos agronegócios tem uma origem muito distante da realidade do produtor rural, que é obrigado a se adaptar a elas sob pena de não conseguir atender ao desenvolvimento tecnológico da cadeia (ou das cadeias) na qual se insere.

Considerando-se que as atividades de produção agroindustriais estão fundamentadas em fatores ainda não plenamente controlados pelos agentes de produção, como clima e o próprio caráter biológico de formação dos produtos. Além disso, foi também considerado que se trata de um tipo de cultivo, em que cerca de $30 \%$ da produção acional é desenvolvida sob condições de proteção (estufas) (GRAZIANO, 2002) e que por isso, requer um maior nível médio de inclusão tecnológica. Isso faz com que o fator "inovação" assuma um caráter diferenciado, associado às peculiaridades própria desse sistema produtivo. Sendo assim, neste 
bloco, foi priorizada a investigação da inovação considerando tais especificidades, como os atores presentes na localidade identificam esse fator e quais as principais fontes de sua geração.

Bloco "Gestão e Estratégias": traz a análise interna das organizações produtivas da localidade, no sentido de identificar quais as principais estratégias de negócios apresentadas por ela. Essa investigação é fundamentada na análise da percepção que essas trazem quanto ao tipo de negócio que desenvolvem (sua inserção na cadeia, principais fatores limitantes, principiais fatores impulsionadores, etc.) e da estrutura competitiva do ambiente em que estão inseridas. Nesse grupo também se busca investigar o perfil dos responsáveis pela implantação e condução dos negócios. Dada a importância que a geração e a absorção das informações apresentam na construção das estratégias organizacionais e suas conseqüências na estruturação competitiva da localidade, neste bloco, optou-se pela investigação da percepção por parte dos atores locais quanto à importância dessas fontes de informação.

A presente estrutura traz uma interatividade dinâmica entre os fatores associados em cada um dos agrupamentos e por este motivo, apesar de divididos em cinco grupos, os fatores considerados no presente modelo apresentam forte interação entre si.

Quadro 2.3 Autores considerados no desenvolvimento da estrutura analítica proposta

\begin{tabular}{|c|c|c|c|c|}
\hline $\begin{array}{c}\text { BLOCO } \\
\text { COOPERAÇÃO }\end{array}$ & $\begin{array}{c}\text { BLOCO } \\
\text { LOCALIDADE }\end{array}$ & $\begin{array}{c}\text { BLOCO } \\
\text { COOPERATIVAS e } \\
\text { ASSOCIAÇÕES }\end{array}$ & $\begin{array}{c}\text { BLOCO INOVAÇÃO } \\
\text { e INFORMAÇÕES }\end{array}$ & $\begin{array}{l}\text { BLOCO GESTÃO e } \\
\text { ESTRATÉGIAS }\end{array}$ \\
\hline $\begin{array}{l}\text { Perez (1999) } \\
\text { Awauh (2001) } \\
\text { Awuah (2001) } \\
\text { Bair e Gereffi (2001), } \\
\text { Carvalho e Laurindo } \\
\text { (2003) } \\
\text { Cassiolato e Lastres } \\
\text { (2001) } \\
\text { Drejer (2001) } \\
\text { Dunphy et al. (1997) } \\
\text { Lawer (,1994) } \\
\text { Lins (2000), } \\
\text { Nadiv (1999) } \\
\text { Porter (1998); } \\
\text { Prahalad e } \\
\text { Ramaswany (2000) e } \\
\text { Prahalad e Hammel } \\
\text { (1990). } \\
\text { Rabelotti (1997) } \\
\text { Suzigan et al. (2001) }\end{array}$ & $\begin{array}{l}\text { Brum e Wedekin } \\
\text { (2001) } \\
\text { Campeao (2004) } \\
\text { Carvalho e } \\
\text { Laurindo (2003) } \\
\text { Cassiolato e } \\
\text { Lastres (2001) } \\
\text { Humprey (2003) } \\
\text { Humprey e } \\
\text { Schmitz (2000) } \\
\text { Nadiv e Schmitz } \\
\text { (1997, 1999) } \\
\text { Porter (1993, } \\
\text { 1998); } \\
\text { Steinle e Schiele } \\
\text { (2002) }\end{array}$ & $\begin{array}{l}\text { Carvalho e } \\
\text { Laurindo (2003) } \\
\text { Cassiolato e } \\
\text { Lastres (1999) } \\
\text { Farina et. al } \\
\text { (1997) } \\
\text { Furman et al. } \\
(2002) \\
\text { Miglino (2003) } \\
\text { Porter (1991,1993 } \\
\text { e 1998) } \\
\text { Niosi (1991) } \\
\text { Schmitz (2000) } \\
\text { Silva (2000) }\end{array}$ & $\begin{array}{l}\text { Bair e Gereffi } \\
(2001), \\
\text { Garcia (2003) } \\
\text { Gereffi (1999) } \\
\text { Humphrey e } \\
\text { Schmitz, (2000) } \\
\text { Jank (1996) } \\
\text { Porter e Millar } \\
\text { (1985) } \\
\text { Schmitz (1995) } \\
\text { Williamson (1985) }\end{array}$ & $\begin{array}{l}\text { Ansoff (1977) } \\
\text { Carvalho e Laurindo } \\
\text { (2003) } \\
\text { Mintzberg (1992), } \\
\text { Porter (1996) } \\
\text { Quinn (1992), } \\
\text { Slack et al. (2002) }\end{array}$ \\
\hline
\end{tabular}




\section{CAPÍTULO 3. ABORDAGEM METODOLÓGICA}

Neste capítulo apresenta a abordagem metodológica proposta para o desenvolvimento desta tese, detalhando os objetivos, proposições e hipóteses, bem como os protocolos da pesquisa de campo. Também serão apresentadas as limitações relacionadas ao objeto do presente estudo.

\subsection{CARACTERIZAÇÃO DO PROBLEMA}

O problema indutor do presente estudo está relacionado ao entendimento de por que as concentrações geográficas de empresas são capazes de gerar vantagens competitivas tanto ao nível individual das empresas quanto ao nível coletivo, bem como identificar quais são os fatores podem interferir na formação de competências coletivas, parcerias e externalidades incidentais desses agrupamentos, tanto ao nível individual das empresas quanto ao nível coletivo, tendo como objeto de estudo, o setor de agronegócio de flores e plantas ornamentais.

Neste capítulo discute-se, face ao problema apresentado, a melhor estratégia para a pesquisa.

\subsection{TIPO DE PESQUISA}

A definição do tipo de pesquisa é ainda um tema complexo, em que convivem diferentes classificações que, em geral, podem estar presentes em um mesmo trabalho (MATTAR, 1993; SELITIZ et al.1975).

Green e Carmne (1988) classificaram as pesquisas em três tipos: exploratórias, descritivas e causais. Segundo esses autores, o estudo exploratório freqüentemente é o primeiro em uma série de vários procedimentos, que preparam a 
busca de inferências entre diversas variáveis estudada. Segundo esses autores, os estudos descritivos, estão focados na descrição de características ou funções e freqüentemente, envolve a descrição do grau de associação entre duas variáveis ou mais, podendo também ser utilizados quando se busca fazer inferências entre as variáveis estudadas, visando basicamente "apresentar com precisão as características de uma situação, um grupo ou um indivíduo específico." Já os estudos causais são considerados como aqueles que buscam estabelecer e entender as relações de causa e efeito, entre os fatores de estudo, por meio do controle das variáveis envolvidas (GREEN; CARMNE, 1988; SELITIZ et al. 1975).

Yin (2001), apresenta um quadro associativo entre os principais tipos de perguntas de pesquisa, resultantes de determinado problema e suas respectivas opções metodológicas, representadas no Quadro 3.1.

Quadro 3.1. Principais características e correspondências entre as estratégias de pesquisa e os tipos de questões levantadas (Adaptado de Yin, 2001)

\begin{tabular}{|c|c|c|c|}
\hline Estratégia & $\begin{array}{c}\text { Forma da } \\
\text { questão de } \\
\text { pesquisa }\end{array}$ & $\begin{array}{c}\text { Exige controle } \\
\text { sobre } \\
\text { eventos } \\
\text { comportamentais }\end{array}$ & $\begin{array}{c}\text { Focaliza } \\
\text { Acontecimentos } \\
\text { contemporâneos }\end{array}$ \\
\hline Experimento & Como, por quê & $\operatorname{sim}$ & Sim \\
\hline Levantamento & $\begin{array}{l}\text { Quem, o quê, } \\
\text { onde, quanto }\end{array}$ & Não & Sim \\
\hline $\begin{array}{l}\text { Análise de } \\
\text { arquivos }\end{array}$ & $\begin{array}{l}\text { Quem, o quê, } \\
\text { onde, quanto }\end{array}$ & Não & Sim/não \\
\hline $\begin{array}{l}\text { Pesquisa } \\
\text { histórica }\end{array}$ & Como, por quê & Não & Não \\
\hline $\begin{array}{l}\text { Estudo de } \\
\text { caso }\end{array}$ & Como, por que & Não & Sim \\
\hline
\end{tabular}

Baseando-se nos referenciais acima tratados, tem-se neste trabalho, características predominantes dos tipos de pesquisa, exploratória e descritiva, trazendo elementos de ambas classificações, uma vez que busca explorar em uma dada concentração geográfica de agronegócios de flores e plantas ornamentais, a estrutura de relacionamento inter-firmas e dessas com organizações de apoio, tais como instituições de governo e associações de classe, por exemplo. Além disso, busca-se também analisar as formas de governança existentes no cenário de estudo, associado do estudo da governança no sistema agroindustrial de flores e 
sua conseqüente influencia na construção de uma competência local específica, descrevendo suas principais variáveis relacionadas ao escopo da pesquisa.

\subsection{O PROJETO DE PESQUISA}

Segundo Selitiz et al. (1975) após a formulação clara do problema de pesquisa, faz-se necessário estabelecer o plano de pesquisa, capaz de acolher de maneira coerente os dados e informações necessárias, para se atingir os objetivos da pesquisa. Esse planejamento, segundo os autores, refere-se à organização das condições para a coleta e análise dos dados, “... que procure combinar o significado para o objeto de pesquisa, com a eficiência e economia do processo".

Dado a complexidade do fenômeno estudado, optou-se por mesclar diferentes estratégias de pesquisa. Em uma primeira etapa de investigação, utilizaram-se alguns aspectos da pesquisa de arquivos e pesquisa histórica para caracterizar o agronegócio brasileiro, o segmento de flores e plantas ornamentais. Isso permitiu, pelo critério de relevância no cenário paulista deste segmento, a seleção das duas localidades estudadas nesta tese: Holambra e Mogi das Cruzes. Finalmente, para as duas localidades selecionadas foram levantados dados históricos e sócioeconômicos.

A estratégia de campo adotada valeu-se de pesquisa empírica de caráter qualitativo e quantitativo. O estudo de campo teve início com uma pesquisa exploratória de caráter qualitativo, no qual foram realizadas diversas entrevistas com os principais atores em ambas localidades, além de entrevistas com pessoas influentes (stakeholder) do setor do agronegócio em geral e do segmento de flores em particular.

Em uma segunda etapa da pesquisa empírica, de caráter mais descritivo, foi feito um levantamento de campo, do tipo survey, em que foram aplicados questionários em ambas localidades e elaboradas análises estatísticas com os softwares específicos.

As seções seguintes detalham os procedimentos da pesquisa. 


\subsubsection{Levantamento de dados secundários}

O levantamento de dados secundários foi feito a partir de uma análise documental, realizada com dois objetivos: reforço estrutural do arcabouço teórico e conceitual empregado na pesquisa e para obter informações mais detalhadas sobre as características sócio-econômicas das localidades estudadas. Para tanto, foi desenvolvida uma detalhada revisão de literatura sobre o assunto, baseada em livros técnicos e acadêmicos, revistas científicas, trabalhos acadêmicos, além de diversos outros tipos de informações (jornalísticas, de órgãos governamentais, de organismos de classe, etc.).

Para a caracterização dos agronegócios, do segmento de flores e plantas ornamentais e das duas localidades, foram levantados dados junto aos órgãos de governo e fundações/ institutos especializados em estudos sócio-econômicos. As principais fontes foram a Fundação SEADE, o IPEA e o IBGE, alguns deles disponíveis nos sítios oficiais destes órgãos públicos.

Para a caracterização do contexto histórico das localidades foram utilizados, além das fontes secundárias já elencadas, documentos disponíveis na prefeitura e nas associações e cooperativas de ambas localidades. Os resultados desta etapa são descritos no Capítulo 4 desta tese.

\subsubsection{Procedimentos da Pesquisa Qualitativa}

As entrevistas foram efetuadas em uma primeira etapa do trabalho, anda de caráter exploratório, visando o aprofundamento das questões de pesquisas, utilizando a estrutura teórico-conceitual apresentada no Capítulo 2. 
A pesquisa foi realizada com atores locais e externos às localidades estudadas. Os atores locais foram representados pelos seguintes segmentos: unidades agrícolas de produção (produtores rurais); associação de produtores rurais, entidades de apoio; sindicatos rurais, cooperativas de produção e/ou comercialização, associação comercial local e demais empresas relacionadas aos agronegócios de flores na localidade, mas que não se caracterizam como unidades agrícolas de produção. Já os atores externos foram representados pela Câmara Setorial de Flores e Plantas Ornamentais e pelo CEAGESP.

Nas seções seguintes detalha-se a amarração das questões com as proposições da pesquisa qualitativa, bem como apresenta-se os instrumentos de levantamento de dados (roteiros) que foram utilizados neste estudo exploratório e os critérios utilizados para a seleção dos entrevistados.

\subsubsection{Questões Específicas e Proposições do Estudo}

As questões correspondem à essência do que realmente o pesquisador tem como objetivo de estudo e análise (YIN, 2001) e neste contexto, pretendeu-se responder as seguintes questões:

> Como as concentrações geográficas de agronegócios de flores são capazes de gerar vantagens competitivas às empresas nele inseridas e ao conjunto como um todo?

> Quais são os fatores determinantes da formação de externalidades em uma concentração geográfica de empresas de caráter agroindustrial?

$>$ Quais são os fatores críticos de sucesso dos processos de interação e cooperação entre empresas localizadas em concentrações geográficas de agronegócios de flores?

> Como se dão e quais são as relações entre as empresas da concentração estudada?

> Como a estrutura de coordenação das cadeias pode influenciar nas estratégias competitivas das empresas individualmente e da concentração estudada? 
> Como são desenvolvidas as competências coletivas dentro da concentração estudada?

$>$ Como são estabelecidas as relações com o poder público local?

> Quais são as ações do poder publico, em suas várias esferas, para fomentar a competitividade do agronegócio de flores nas concentrações de empresa?

Para buscar respostas consistentes a estas questões, quando se desenvolve uma pesquisa do tipo exploratória, algumas proposições devem ser levantadas (YIN,2001). Neste contexto, as proposições associadas ao estudo exploratório são:

1. A concentração geográfica de empresas do agronegócio de flores cria condições para promover maior número de ações conjuntas (joint actions), sendo que esta interação entre empresas é um importante fator gerador das vantagens competitivas presentes nos agrupamentos locais.

2. A concentração geográfica de empresas cria externalidades incidentais, que se mostram determinantes para a competitividade das empresas e da localidade.

3. O desempenho competitivo das empresas depende das relações sistêmicas e das condições de governança na cadeia de valor no qual estão inseridas.

4. No contexto dos agronegócios de flores e plantas ornamentais, instituições de governo em suas várias esferas podem induzir ações cooperativas entre os componentes de uma localidade, atuando como agentes coordenadores, gerando com isso influencias importantes nas estratégias competitivas das empresas da localidade, tanto ao nível individual quanto em nível coletivo.

As relações entre as proposições e questões estudadas estão apresentadas no Quadro 3.2. 


\subsubsection{Instrumento e Critérios para Seleção dos Entrevistados}

Godoy (1995) destaca que os principais métodos empregados nas pesquisas exploratórias e descritivas são a observação e a entrevista. No presente estudo utilizou-se uma análise documental e a aplicação de roteiros de entrevista, com questões semi-estruturadas, discriminados por grupo de atores, detalhados adiante.

Quadro 3.2. Relação entre as Questões e Proposições elaboradas no presente estudo.

\begin{tabular}{|c|c|}
\hline PROPOSIÇÃO & QUESTÕES \\
\hline $\begin{array}{l}\text { A concentração geográfica de empresas do } \\
\text { agronegócio de flores cria condições para } \\
\text { promover maior número de ações conjuntas } \\
\text { (joint action), sendo que esta interação entre } \\
\text { empresas é um importante fator gerador das } \\
\text { vantagens competitivas presentes nos } \\
\text { agrupamentos locais }\end{array}$ & $\begin{array}{l}\text { Quais são os fatores críticos de sucesso dos } \\
\text { processos de interação e colaboração entre } \\
\text { empresas localizadas em concentrações geográficas } \\
\text { de agronegócios de flores } \\
\text { D Como se dão e quais são as relações entre as } \\
\text { empresas da concentração estudada? }\end{array}$ \\
\hline $\begin{array}{l}\text { A concentração geográfica de empresas cria } \\
\text { externalidades incidentais, que se mostram } \\
\text { determinantes para a competitividade das } \\
\text { empresas e da localidade }\end{array}$ & $\begin{array}{l}\text { D Quais são os fatores determinantes da formação de } \\
\text { externalidades nas concentração geográfica de } \\
\text { empresas de caráter agroindustrial? } \\
\text { D Como são desenvolvidas as competências } \\
\text { coletivas dentro da concentração estudada? }\end{array}$ \\
\hline $\begin{array}{l}\text { O desempenho competitivo das empresas } \\
\text { depende das relações sistêmicas e das } \\
\text { condições de governança na cadeia de valor no } \\
\text { qual estão inseridas }\end{array}$ & $\begin{array}{l}\text { Como as concentrações geográficas de } \\
\text { agronegócios de flores são capazes de gerar } \\
\text { vantagens competitivas às empresas nele inseridas e } \\
\text { ao conjunto como um todo? } \\
\text { D Como a estrutura de coordenação das cadeias } \\
\text { pode influenciar nas estratégias competitivas das } \\
\text { empresas individualmente e da concentração } \\
\text { estudada? }\end{array}$ \\
\hline $\begin{array}{l}\text { No contexto dos agronegócios de flores e } \\
\text { plantas ornamentais, instituições de governo em } \\
\text { suas várias esferas podem induzir ações } \\
\text { cooperativas entre os componentes de uma } \\
\text { localidade, atuando como agentes } \\
\text { coordenadores, gerando com isso influencias } \\
\text { importantes nas estratégias competitivas das } \\
\text { empresas da localidade, tanto ao nível individual } \\
\text { quanto em nível coletivo }\end{array}$ & $\begin{array}{l}\text { Como são estabelecidas as relações com o poder } \\
\text { público local? } \\
\text { Q Quais são as ações do poder público, em suas } \\
\text { várias esferas para fomentar a competitividade do } \\
\text { agronegócio de flores nas concentrações de } \\
\text { empresa? }\end{array}$ \\
\hline
\end{tabular}

Fonte: o autor

Segundo Mattar (1993) nas entrevistas, busca-se aprofundar o conhecimento sobre o assunto, através de uma amostra intencional. Neste estudo foram focalizados os gestores e principais atores das empresas, organismos de governo, associações (produtores e empresariais), etc.

As entrevistas foram realizadas através de um questionário semi-estruturado com questões diretas e com as respostas obtidas pelos dizeres dos próprios 
entrevistados, caracterizando o que Mattar (1993) considerou como "entrevista em profundidade".

Visando garantir maior interação do entrevistado com o processo da entrevista, optou-se pela elaboração de roteiros específicos (Anexo $A$ ), com questões voltadas para o perfil do grupo entrevistado, mas mantendo-se, entretanto, uma estrutura, em blocos, que garantisse a obtenção dos elementos dessa pesquisa e posteriormente, a análise. Foram identificados para a pesquisa qualitativa quatro grupos de atores na localidade: associações de produtores rurais; entidades de apoio; cooperativas de produção e/ou comercialização; e empresas meio.

Optou-se por não construir um roteiro específico na pesquisa qualitativa para os produtores rurais, devido ao fato da amostra de representantes considerados nas grupos elencados anteriormente, contarem com produtores rurais como membros executivos das cooperativas e associações de produtores locais.

Os quatro grupos são apresentados a seguir:

a) Associações de Produtores Rurais: as associações de produtores rurais são formas tradicionalmente utilizadas pelos produtores com a finalidade de atingir a objetivos específicos, geralmente associados à melhoria das condições tecnológicas e/ou de comercialização. Vários trabalhos na literatura acadêmica reportam sobre a importância deste tipo de associação no contexto rural brasileiro. O critério de seleção do entrevistado foi pertencer ao corpo diretor da(s) associação(ões) estudada(s) em cada localidade. Assim, considera-se que as respostas dos entrevistados, representem a visão e a realidade de sua associação.

b) Cooperativas: por serem organizações com características muito especificas de gestão e funcionamento, onde a confiança, transparência e ações cooperativas entre os sócios são requisitos necessários para o alcance dos propósitos buscados. $O$ papel das cooperativas agrícolas na criação de vantagens competitivas aos produtores rurais é historicamente comprovado (JERÔNIMO,2005). As cooperativas apresentam peculiaridades de gestão e propósitos diferentes das associações em muitos aspectos, como questões legais, tributárias e organizacionais. Por este motivo foi elaborado um roteiro de entrevista que buscasse maior adequação a essa realidade. As entrevistas foram conduzidas com representante(s) da alta administração (membro do corpo diretor) da(s) cooperativa(s) estudada(s) em cada 
localidade. O foco dessas entrevistas foram às cooperativas de produtores da localidade que atuassem diretamente na área de produção e/ou comercialização de flores e/ou plantas ornamentais.

c) Empresas Meio: no presente trabalho, denominou-se como "Empresas Meio" o grupo de empresas que não atuam diretamente na atividade de produção de flores e plantas ornamentais, mas que participam do sistema produtivo estudado. Assim, foi elaborado um roteiro que buscasse o entendimento de como essas empresas enxergam sua participação e/ou inserção com os negócios da localidade e como elas desenvolvem esses negócios. Considerando-se que em Holambra ocorre o maior evento nacional relacionado aos negócios da floricultura, a Hortitec, no qual participam empresas que se relacionam com todos os pólos floriculturistas do Brasil, optou-se por entrevistar os representantes dessas empresas que participaram das edições de 2005 e 2006 desse evento.

d) Entidades de apoio: a importância das entidades de apoio na geração de vantagens competitivas nas concentrações geográficas de empresas foi abordada no Capítulo 2. Para a realização deste estudo, foram consideradas como organizações de apoio, todas as organizações privadas e/ou públicas que atuam no desenvolvimento de atividades voltadas para a promoção do desenvolvimento gerencial e/ou tecnológico da cadeia produtiva de flores. Assim, como entidades de apoio foram consideradas o SEBRAE, SENAR, Sindicato Rural, Associação Comercial Local, e demais associações que visam esse tipo de objetivo.

O Quadro 3.3 apresenta o número de entrevistas realizadas por grupo de atores e por localidade.

Um quinto grupo, que também contou com roteiro de entrevista específico, era composto de atores externos às localidades estudadas: o presidente da Câmara Setorial de Flores e a chefe do centro de qualidade em horticultura da CEAGESP. 
Quadro 3.3 Composição da amostra da pesquisa qualitativa

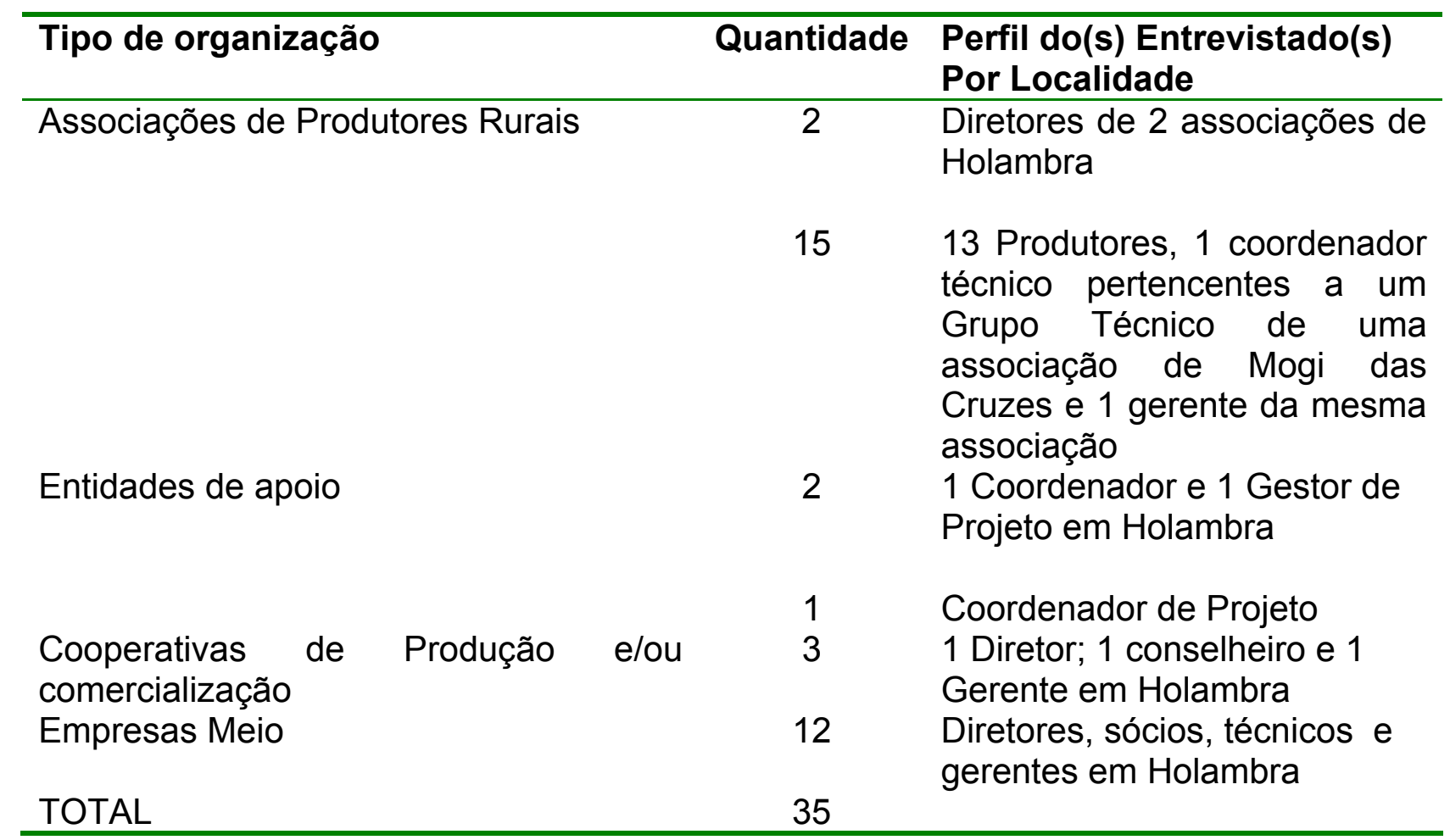

Fonte: o autor

De maneira geral, todos os roteiros de entrevistas para os 4 grupo de atores estudados, eram estruturados em 5 blocos: caracterização geral da organização/entidade; cooperação e parceria; localidade; inovação/informações e o bloco gestão e estratégias. Os roteiros completos, descriminado por grupos, são apresentados no Anexo A, Trazem como ponto central e comum, questões relacionadas à estrutura teórico-conceitual apresentada no Capítulo 2, englobando temas como: desenvolvimento de competências, informações de mercado e produção, cooperação inter-empresas, relações das empresas com seus clientes e fornecedores, desenvolvimento de ações conjuntas, entre outros.

A análise dos dados foi efetuada de forma descritiva embasada na visão sistêmica da cadeia de valor, que segundo Batalha e Sacrpelli (2005) possibilita a compreensão da forma como a cadeia funciona e sugere as variáveis que afetam o desempenho do sistema agroindustrial de produção.

Os resultados desta etapa são descritos no Capítulo 5 desta tese. 
3.3.3 Pesquisa Quantitativa: levantamento do tipo survey

Conforme discutido, a pesquisa também fará uso de levantamento de campo, tipo survey, para qual é importante definir as hipóteses a serem investigadas. AlvezMazzotti e Gewandsnadjer (1998) alertam que o uso de hipóteses no processo investigativo deve ser usado somente quando se dispõem de dados confiáveis e testáveis, uma vez que as hipóteses são baseadas nas relações entre variáveis. Assim as hipóteses a serem testadas nesta tese são:

Ho1: Não existe diferença na percepção da importância da identidade étnico-cultural como um fator determinante nas relações de cooperação para os grupos étnicos estudados

$H_{A} 1$ : Existe diferença na percepção da importância da identidade étnico-cultural como um fator determinante nas relações de cooperação para os grupos étnicos estudados.

Ho2: Não existe diferença na percepção da importância das cooperativas / associações como um fator determinante para 0 sucesso dos negócios, considerando-se as localidades.

$H_{A}$ 2: Existe diferença na percepção da importância das cooperativas / associações seja um fator determinante para o sucesso dos negócios, considerando-se as localidades.

Ho3: Não existe diferença na percepção da importância do papel do poder público local para a construção das bases competitividade das empresas do agronegócio, considerando-se as localidades.

$H_{A}$ 3: Existe diferença na percepção da importância do poder público local para a construção das bases competitividade das empresas do agronegócio, considerando-se as localidades.

$H_{0} 4:$ Não existe diferença na percepção da importância da permanência na localidade de Holambra/Mogi para a competitividade das empresas do agronegócio nela situadas, considerando-se as localidades.

$H_{A} 4$ : Existe diferença na percepção da importância da permanência na localidade de Holambra/Mogi para a competitividade das empresas do agronegócio nela situadas, considerando-se as localidades. 
O levantamento do tipo survey realizado nesta tese apresenta amostra não probabilística. Foram aplicados 120 questionários e foram obtidas 90 respostas válidas. Dentre as respostas 90 válidas obteve-se, respondidas por produtores de unidades agrícolas de produção, dos quais 80 da localidade de Holambra e 10 da localidade de Mogi das Cruzes.

A coleta dos dados foi efetuada através de questionários com questões fechadas (FORZA, 2002) com 119 variáveis, distribuídas nos blocos seguintes blocos: caracterização geral; parceria e ação conjunta, localidade e cooperativismo e associativismo. A aplicação dos questionários foi feita em situações onde houvesse maior numero de agricultores reunidos, como reuniões e/ou assembléias de associações de produtores e/ou das cooperativas locais.

Assim como descrito para a pesquisa qualitativa, como forma de garantir maior interação do entrevistado com o processo da entrevista, optou-se pela elaboração específica dos questionários relacionado à localidade estudada, mantendo-se entretanto, uma estrutura que garantisse a obtenção dos elementos dessa pesquisa. Assim, foram elaborados dois questionários (uma para cada localidade) que podem ser mais bem observados no Anexo B.

A análise dos resultados foi baseada em três tipos de análises estatísticas: fatorial por componente principal com rotação varimax (JOHNSON; WICHERN, 1998; AGRESTI, 1990), análise discriminante e o teste qui-quadrado.

Foram criados fatores que representem a percepção conjunta de algumas perguntas relacionadas. Com base nesses fatores, foram realizadas análises de agrupamentos "cluster" pelo método de K-médias (JOHNSON; WICHERN, 1998) e criados grupos mais homogêneos de empreendimentos para saber quais as características desses grupos. As características foram descritas com uso de medidas descritivas (médias, desvios padrões, mediana, mínimo e máximo) (BUSSAB; MORETTIN, 1987) de cada fator e observado o percentual de municípios em cada grupo. Como ferramenta para realização dessas análises, utilizou-se os seguintes Softwares: SPSS,13, Excel 2003, MINITAB 14.0 e SPSS.

Os resultados desta etapa são descritos no Capítulo 6 desta tese. 


\subsection{O RECORTE DA PESQUISA (LIMITAÇÕES)}

Em função do objeto de estudo escolhido para o desenvolvimento de presente trabalho, algumas limitações são inerentes ao próprio processo de investigação e estruturação do projeto aqui apresentado.

Este trabalho, conforme foi discutido no quadro teórico, tem fronteira com diversas áreas do conhecimento $\mathrm{e}$ isto exigiu forte disciplina no campo epistemológico da análise.

Mostrou-se necessário para o desenvolvimento desse estudo explicitar que não se pretende analisar a fundo os aspectos sociais e culturais que atuam também como condicionantes da competitividade dos agrupamentos locais nem estudar os fatores determinantes para formação de tais concentrações geográficas de empresas.

Uma outra limitação presente neste estudo, está na própria escolha da área de negócios a ser pesquisada: os agronegócios. Essa é uma área importante da economia nacional, que por sua vez, traz em si uma gama muito intensa de atividades a ela relacionada, uma vez que envolve a produção de flores, alimentos, fibras e biomassa de fim energético.

Isso posto, optou-se neste estudo, pelo recorte dado ao setor de flores, sob a justificativa já apresentada anteriormente. Ainda sob o contexto da floricultura, no presente trabalho viu-se obrigado a fazer a opção pelo estudo específico nas regiões paulistas de Holambra e Mogi das Cruzes, cuja importância para o setor estudado também já foi abordado.

Assim, os resultados encontrados nesta tese limitam-se ao segmento de flores e plantas ornamentais, que apresentam especificidades que limitam sua extensão para os agronegócios, embora possam trazer informações relevantes para este contexto.

Finalmente, destacam-se as limitações da abordagem metodológica utilizada, como a amostra não probabilística, que não permite a generalização das conclusões para o universo estudado e os aspectos inerentes ao estudo exploratório de caráter qualitativo já apontado na literatura. 


\section{CAPÍTULO 4. O AMBIENTE DE ESTUDO}

\subsection{O AGRONEGÓCIO BRASILEIRO DE FLORES}

Segundo dados apresentados pelo Instituto Brasileiro de Floricultura - Ibraflor (IBRAFLOR, 2006) o setor de flores e plantas ornamentais hoje é responsável pela geração de mais de 120 mil empregos diretos, dos quais 58 mil (48,3\%) alocados diretamente nas atividades de produção; 4 mil (3,3\%) em distribuição e logística distribuição; 51 mil (42,5\%) no comércio varejista e 7 mil (5,9\%) em funções como apoio, administração e etc.

No contexto nacional da caracterização do agronegócio brasileiro de flores, no que tange a estrutura, principais atores, área cultivada, tipo de cultivo e valor anual de produção, alguns estudos mais recentes se destacam: Francisco et al. (2003 a,b) e o de Kiyuna et al. (2003 e 2004).

O trabalho apresentado por Kiyuna et al. (2004), mostra-se fundamental para a construção de uma base de dados e informações sólidas capaz de contribuir para a construção de um painel que melhor represente a estrutura, a grandeza e os mecanismos de funcionamento do agronegócio de flores no Brasil. Em termos gerais, nesse estudo, os autores identificaram os seguintes aspectos, relacionados a seguir:

a) A significativa parcela de $64 \%$ da área cultivada que recebe assistência técnica, que segundo os autores, é um dos principais aspectos relacionados à floricultura moderna.

b) Nos Estados onde a floricultura é mais recente, há maior busca por treinamentos (á exemplo do Ceará) ao contrário do observado em estados onde a floricultura já apresenta uma maior tradição, como São Paulo e Minas Gerais.

c) $58 \%$ dos produtores nacionais, representando cerca de $60 \%$ da área cultivada em todo o território nacional, apresentam algum tipo de associativismo. 
d) Os produtores com áreas superiores a 10 hectares (principalmente entre 20 e 50 ha), voltados para o mercado interno, apresentam maior grau de organização em cooperativas ou associações, utilização de escrituração agrícola, treinamento e acesso a crédito.

e) Os produtores voltados para o mercado externo possuem perfil diferenciado dos demais, no tocante à especialização, a escala de produção e apresentam um certo grau empresarial no gerenciamento de suas atividades

f) Existe uma elevada absorção de mão-de-obra, principalmente familiar e permanente, numa média de 3,7 homens/ha. A média paulista é de 3,8 homens/ha, sendo que essa utilização, sazonalmente pode chegar até a 20 homens/ha em propriedades com até 1 ha, sendo que nesses casos a tecnologia empregada é ainda maior.

g) A capacidade de armazenamento em câmara fria está concentrada em São Paulo, com 34 mil m$^{3}$ seguido do Estado de Minas gerais com cerca de $3 \mathrm{mil} \mathrm{m}^{3}$.

h) Os produtores se utilizam principalmente dos atacadistas e/ou varejistas para a comercialização no mercado interno.

i) Ainda é pequeno o numero de produtores voltados para exportação, muito disso devido à preferência especifica de cada país importador por um único produto ou grupo de produtos. Essa situação cria também uma especialização dos Estados para exportação de seus produtos

Kiyuna et al. (2003) relatam que a ausência de dados recentes e detalhados, dificulta muito o trabalho de caracterização mais precisa desse setor. Segundo esses autores, o último CENSO Agropecuário foi realizado no período de 1995-96 e nem todos os dados referentes ao setor de floricultura foram publicados. Os dados mais recentes sobre esse setor, ao nível nacional, foram publicados por Graziano (2002), num trabalho baseado nos dados de pesquisa realizada pelo Ibraflor, junto a produtores de quinze Estados. Segundo Kiyuna et al. (2003), esse trabalho permitiu com certa segurança, uma extrapolação, análise e interpretação representativa em nível nacional. 
No caso especifico da floricultura paulista, a mais importante no contexto nacional (COSTA:CAIXETA FILHO, 2002; FRANCISCO et al. 2003a; KIYUNA et al. 2003 e 2004 ) existem dados mais recentes que foram analisados por Kiyuna et al. (2003) e que muito auxiliam não só para estabelecer a caracterização desse setor em nível estadual, como também para melhor caracterização em nível nacional, dada a representatividade alcançada pelo Estado paulista nessa área.

As informações disponíveis sobre as áreas ocupadas com plantio de flores no Brasil apresentam uma certa divergência quantitativa, mas que assim mesmo conseguem exprimir a importância crescente desse setor frente aos agronegócios brasileiros.

Como toda atividade hortícola, a produção de flores é basicamente desenvolvida em pequenas propriedades e requer um maior nível de investimento tecnológico se comparado ao nível de investimento necessário para as atividades frutícolas ou plantio de grandes culturas, por exemplo. Assim, essa atividade passa a requerer uma melhor capacitação tanto da mão-de-obra produtiva como também por parte dos agentes gestores (CLARO,1998). Tal colocação é corroborada pelo estudo de Kiyuna et al. (2003), que mostra um forte perfil de organização associativista desses produtores, associado a um forte caráter tecnológico, evidenciando pelo intensivo uso de ferramentas informatizadas de gestão, escrituração agrícola, acesso ao crédito e treinamento.

A principal forma de comercialização e distribuição de flores e plantas ornamentais é feita através de centrais de comercialização, algumas específicas para esse tipo de produto, como o Veiling Holambra e o Mercaflor-SC (CLARO; OLIVEIRA, 1999; CASTRO 1998). Outra forma crescente de comercialização desses produtos é através da internet que já conta no Brasil com algumas empresas operando dessa maneira (LOURENZANI et al. 2002).

Segundo Motos e Nogueira Jr. (2001), existiu uma preocupação por parte dos agentes nacionais de governo para incentivar os mercados externos de flores, que levou à assinatura de um convênio entre a Apex e o lbraflor em outubro de 2000, cujo principal objetivo era alcançar US\$ 80 milhões em exportações no ano de 2003. No entanto, os dados apresentados por Kiyuna et al. (2005) evidenciam que essa meta era extremamente otimista e irreal. Neste trabalho, os autores mostram que apesar de ter havido a manutenção de uma tendência de crescimento das 
exportações brasileiras nos últimos cinco anos, em 2003 o Brasil alcançou a marca de U\$19.5 milhões (muito abaixo dos U\$ 80 milhões estimados) e U\$23,6 milhões em 2004. Segundo os autores, o desempenho de 2003 e 2004 foi excepcional e muito influenciado pelo empenho do governo brasileiro associado à determinação dos produtores organizados em entidades setoriais. Nesse estudo ainda, os autores ressaltam que os principais compradores em 2004 foram a Holanda, seguido dos Estados Unidos, Itália, Japão, Reino Unido e Alemanha, que juntos, absorveram $83 \%$ das exportações nacionais, dos quais somente a Holanda absorveu $49,5 \%$ do tal de exportações, enquanto que os Estados Unidos ficaram com 21,8\%.

Mesmo sendo em um período em que a moeda brasileira mostrava-se valorizada frente à moeda americana, dados publicados pelo Ministério da Agricultura, Pecuária e Abastecimento (MAPA 2006), revelam que no primeiro semestre de 2006 as exportações brasileiras de flores e plantas ornamentais cresceram cerca de $8 \%$ em relação ao mesmo período do ano anterior, totalizando pouco mais de US\$ 15 milhões. Com relação às importações, esses dados mostram que apesar de expressivas, as importações de flores frescas de corte bulbos, tubérculos e rizomas em processo de vegetação ou florescimento, não mostraram uma tendência acentuada de crescimento como o observado para as exportações.

Para Kiyuna et al. (2005), o fato de se ter conseguido parte dos mercados americano e holandês de flores frescas para buquês, associado ao fato da cooperativa Veiling de Holambra realizar exportações diárias para esses países, contribuiu muito para esse cenário de crescimento e traz bons prognósticos para 2005.

No que se refere à importação, em 2004 Kiyuna et. al (2005) relatam que essa ficou na casa dos $\bigcup \$ 6,7$ milhões, menos do que no ano anterior. Para esses autores, o saldo positivo da balança comercial se deu mais em função do crescimento das exportações do que pela diminuição das importações.

Esses resultados mostram que além das vantagens comparativas que o Brasil apresenta, em termos de condições naturais para a produção, logística e comercialização de flores, o papel da organização produtiva, capacitação técnica e desenvolvimento tecnológico, ajudam a garantir a confiança externa do setor. Os fatores de organização e de articulação dos atores do sistema agroindustrial de 
flores, mostraram ser responsáveis pela criação de vantagens competitivas sustentáveis para esse setor, que antes não havia.

Nesse contexto, o estudo aqui proposto tem grandes possibilidades de contribuir para a consolidação desse cenário, na medida em que busca, do ponto de vista da estratégia empresarial, compreender melhor os mecanismos da criação dessas vantagens no principal estado produtor do Brasil.

\subsection{O AGRONEGÓCIO PAULISTA DE FLORES}

A importância da floricultura para o Estado de São Paulo reside no fato de que nele está concentrado cerca de $70 \%$ da produção nacional (Kiyuna et al. 2003) e de $75 \%$ dos valores exportados (SANTOS; KIYUNA, 2004). Francisco et al. (2003a) relatam que o valor da produção paulista em 2002 alcançou a ordem de R\$ 235 milhões, superando o valor gerado por culturas tradicionalmente importantes para o Estado, como manga ( $R$ \$ 222 milhões), tangerina ( $R$ \$ 215 milhões) e algodão em caroço ( $R \$ 110$ milhões) e se aproximou de culturas como o feijão ( $R$ \$ 268 milhões) e o tomate para mesa (R\$ 253 milhões).

Claro (1998) estimou em cerca de dois mil produtores de flores e/ou plantas ornamentais no Estado de São Paulo, numero superior ao de 1.465 produtores cadastrados no CENSO Paulista (KIYUNA et al. 2003), refletindo a dificuldade de se obter esses dados com precisão.

O Estado paulista apresenta a maior parte da área cultivada em todo território nacional (cerca de 72\%), abrangendo 97 municípios, sendo que a grande maioria da produção está concentrada em quinze municípios, situados em um triângulo imaginário (Figura 4.1) que tem um de seus vértices ao norte, acima do município de Holambra (-47,04W; -22,05S) ao sul (-48,06W; -24,93S) e ao leste $(-45,82 \mathrm{~W}$; 23,44S) na circunvizinhança do município de Mogi das Cruzes (FRANCISCO et al. $2003 a, b)$.

Esta área engloba as regiões de Holambra e Campinas, se dedicam ao cultivo de uma centena de variedades e mais de duzentas espécies; a região de Atibaia, 
Bragança Paulista e Ibiúna, que se concentra na produção de flores de clima frio em vasos e de corte, crisântemos em vasos e plantas de jardim. Outros municípios como Registro, Mogi das Cruzes, Arujá, Cotia, São Roque e apresentam produção menos significativa (CLARO, 1998; MOTOS:NOGUEIRA JR, 2001).

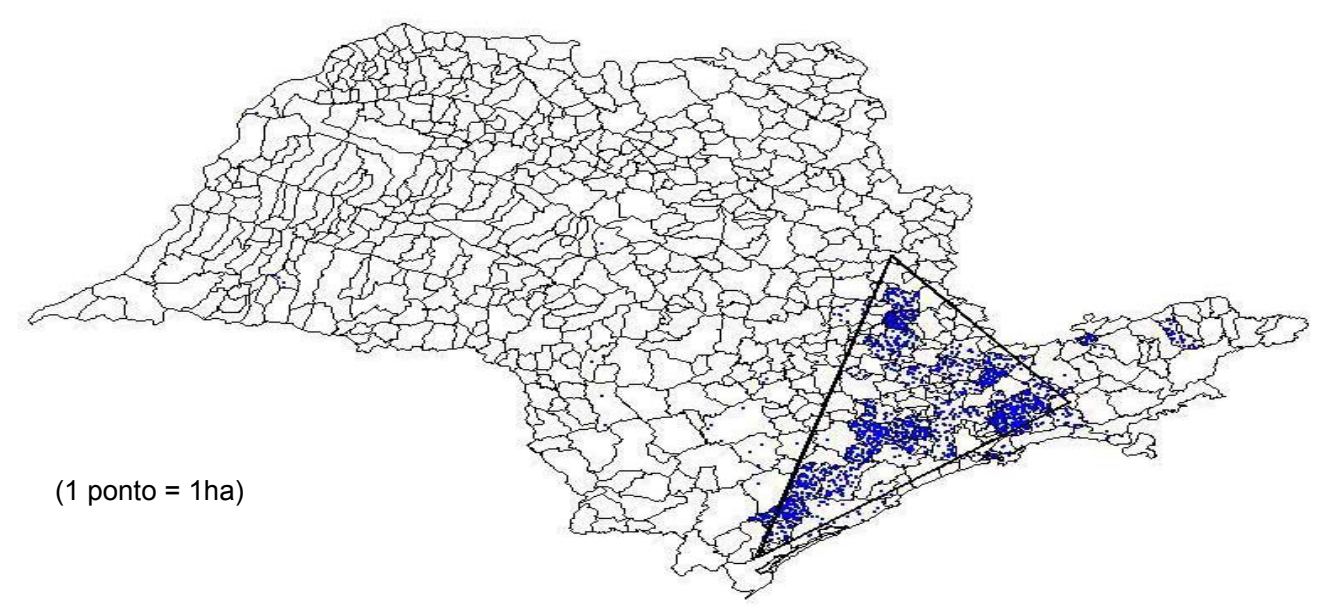

Figura 4.1 - Distribuição Geográfica da Área de Floricultura, Estado de São Paulo, 1995-96. Fonte: Francisco et al. (2003a)

Estudos de Arruda et al. (1996) e Castro (1998) mostram que a maior parte dos municípios paulistas, que desenvolveram a floricultura estão distantes não muito além de 100 kilômetros da capital e sempre próximos a rodovias importantes. Esses dados são complementados pelos estudos de Francisco et al. (2003 a,b) e Kiyuna et al. (2005) que mostram que os vinte municípios responsáveis por cerca de $80 \%$ do valor da produção de flores paulista estão situados num raio de 100 kilômetros das cidades onde se concentram os grandes centros de comercialização (Campinas, São Paulo e Holambra). Além desse fator, esses autores observam que esses municípios apresentam vantagens comparativas relacionadas ao micro-clima e infraestrutura.

Apesar de não terem desenvolvido o trabalho especificamente nessa linha, o estudo de Francisco et al. (2003a) mostra alguns aspectos interessantes, que de certa maneira, podem auxiliar no processo elucidativo da criação das vantagens 
competitivas que esse setor do agronegócio paulista vêm apresentando e dentre eles podem ser destacados:

a) Há entre os produtores paulistas, aquilo que os autores denominaram de "receptividade às inovações" associado à um alto índice tecnológico dos fatores de produção, tais como: irrigação, plasticultura, estufas e câmaras frias e um intensivo uso do computador em suas atividades de produção e gestão dos negócios.

b) Maior grau de interação tecnológica dos aspectos de produção e gestão, aquisição conjunta de insumos e máquinas, melhoria das condições de logística no transporte e comercialização. Tudo isso, segundo os autores, devido ao elevado grau de associativismo apresentado pelos produtores paulistas.

c) Identificaram evidências, qualitativa e quantitativas no que tange às diferenças regionais e culturais relacionadas às práticas de modernização das atividades, destacando-se maior uso intensivo de tecnologia pelos produtores de origem japonesa, enquanto que os de origem holandesa se destacam no uso de computadores na propriedade e intercâmbios técnicos intensivos, sendo que estes, certamente foram influenciados pela proximidade cultural e pelo fato da Holanda ser um dos principais importadores de flores do Brasil.

Esses aspectos consolidados no estudo de Francisco et al. (2003 a) e de certa maneira apresentado nos estudos de Kiyuna (2004;2005), mostram que as interações entre produtores e entre produtores e clientes, associados a um processo efetivo de formação de competências estreitamente relacionadas a origem dos produtores ao papel do associativismo na coordenação das atividades de produção e comercialização, são elementos fundamentais na criação das vantagens competitivas da floricultura paulista e que se mostram bem evidentes nas regiões onde o presente estudo foi realizado. 


\subsection{A LOCALIDADE DE HOLAMBRA}

A Localidade de Holambra considerada no presente estudo, se encontra delimitada pelos municípios de Holambra, Mogi-Mirim, Arthur Nogueira, Cosmópolis, Jaguariúna e Santo Antonio de Posse. Todos integrantes da Região Metropolitana de Campinas, conforme Seade (2003).

A localidade conta hoje com cerca de 300 unidades agrícolas de produção, voltadas em sua maioria para as atividades relacionadas ao agronegócio de flores. Dentre as principais empresas da região, destaca-se o Grupo Schoenmaker, que atualmente é o maior produtor de bulbos da América Latina; líder nacional na produção de tulipas. Esse Grupo também conta com a parceria de empresas coligadas na Holanda que produzem e desenvolvem material básico com uma empresa brasileira voltada para plantas tropicais.

Destacam-se também as empresas Incotec America do Sul Ltda e a Terra Viva Ltda. A primeira atua especificamente na área de pelitização de sementes, e a segunda, presente no município de 1989, atua na área de substratos para desenvolvimento de mudas. Dentre as empresas situadas na localidade, vale destacar a presença de uma: RBB Feiras e Eventos, responsável pela a organização dos principais eventos da cidade (Hortitec Enflor, Expoflora, entre outros) relacionados ao cultivo de flores e plantas.

Além de sediar empresas que atuam em todos os segmentos da cadeia de flores e plantas, a localidade de Holambra conta com a participação de diversas empresas, sediadas em outros municípios mas que atuam de maneira intensa com a localidade no desenvolvimento de seus negócios.

A localidade conta com três cooperativas de produção e comercialização de flores e plantas: Cooperplantas; Cooperflora e Cooperativa Veiling de Holambra $(\mathrm{CVH})$. Dentre elas a CVH é a mais importante em termos de quantidade de cooperados e do volume de comercialização, de flores e plantas. As outras duas cooperativas, apresentam uma semelhança entre si, no tocante ao número de cooperados e a movimentação de negócios na localidade

Das três cooperativas de comercialização e produção existentes na localidade, a Cooperplantas apresenta uma característica peculiar em sua composição: pequenos agricultores que trabalhavam como funcionários em 
propriedades rurais com mais de 20 hectares de floricultura e que posteriormente montaram seu próprio negócio em áreas de até cinco hectares, em média.

Além dessas cooperativas, a localidade de Holambra conta com mais duas cooperativas, estas oriundas do desmembramento da antiga Cooperativa Agropecuária de Holambra (que ainda existe, em processo de liquidação): uma especificamente voltada a compre de insumos agropecuários e a outra relacionada à produção animal.

A localidade de Holambra conta ainda com uma Associação Comercial e Empresarial, um posto de SEBRAE, a Associação Brasileira Comercio Sementes Mudas e uma entidade, denominada ABAFEP - Associação Brasileira do Agronegócio de Flores e Plantas, que trabalha diretamente na distribuição de grande parte dos produtos comercializados na Cooperativa Veiling de Holambra.

No município de Holambra se encontram sediadas duas das três associações de produtores da localidade: Associação Rural do Bairrinho e a Associação de Agricultores Familiares de Holambra. Já em Arthur Nogueira, outro município componente da localidade estudada, se encontra a AAFAN- Associação de Agricultores Familiares de Artur Nogueira.

O mais expressivo município desta localidade, em termos de produção e comercialização de flores é o município de Holambra, que segundo dados Francisco et al. (2003 a) é o segundo município paulista com maior área cultivada com floricultura e que segundo Arruda et al. (1996), chegou a ser responsável por 40\% da produção e comercialização de flores do país.

A geração de valor, característica principal da competitividade de uma empresa e/ou determinada aglomeração local, está primordialmente inserida no contexto dos fluxos de valores presentes nas redes de cidades, uma vez que é nesse nível que se iniciam e desenvolvem as cadeias e sistemas produtivos. Associado à isso, tem-se nos fluxos de informação (presentes na rede de empresas) e nos fluxos de matéria (inseridos num conjunto de aspectos de caráter tais como cultura, qualidade de vida, recursos escassos, entre outros) a caracterização de elementos que, em última análise, vão atuar como agentes inibidores ou promotores das vantagens comparativas, que exercem marcante influencia na integração de todos os fluxos responsáveis pelo caráter competitivo da localidade. 
A forte integração entre o município de Holambra e seus municípios vizinhos está baseada na estrutura das redes sociais. Isso pode ser observado na medida em que a grande maioria dos trabalhadores do setor de flores mora em outras cidades, na proporção de um trabalhador residente para vinte de outras cidades, em especial Artur Nogueira e Santo Antônio de Posse (BRAGA, 2002). Além disso, as três cooperativas de produção e/ou comercialização de flores da localidade estão sediadas nesse município. Essas cooperativas, podem contar com sociocooperados, cujas unidades agrícolas de produção se encontram externas ao município, na sua grande maioria, em municípios componentes da Localidade aqui estudada.

Esse cenário, acaba por concentrar no município, os principais fatores para o desenvolvimento das competências locais de produção e comercialização de flores, onde se concentram os principais fornecedores de mão-de-obra especializada, insumos e infra-estrura de produção, conforme pode ser observado no estudo realizado por Braga (2002). Nesse estudo o autor revelou que somente as empresas de insumos como agroquímicos e embalagens, se encontram predominantemente sediados fora do município, concentrando-se nas capitais ou grandes centro urbanos, como São Paulo, Ribeirão Preto e Rio de janeiro.

Dentre os municípios considerados na Localidade, o município de Holambra apresenta uma rede de relação (em termos de fluxo de valor e informações), mais intensa com os municípios vizinhos de Arthur Nogueira e Santo Antonio de Posse. Além do fluxo de mão-de-obra local, essa dinâmica é intensificada pelo fato de que nesses municípios, estão sediadas empresas com grandes áreas de produção. Além disso, dados relatados pelo corpo diretivo da Cooperativa Veiling, mostram que existe um projeto em andamento para que essa mude suas instalações para o município de Santo Antonio de Posse, motivado exclusivamente pela falta de espaço físico apropriado em Holambra.

Isso traduz, uma forte relação entre os elos e da competitividade do local em seus mais variados níveis, que segundo Porter (1998) é o fator fundamental para delimitação de um dado agrupamento setorial de empresas e que no caso, tem no município de Holambra seu representante maior.

Isso faz com que Holambra represente o caráter central onde os elementos essenciais para a geração da vantagem competitiva da localidade, estão 
concentrados. No entanto, esses mesmos fatores são também os responsáveis pela maior consistência nas relações com os municípios vizinhos, sobretudo os mais próximos, não só devido às identidades culturais entre os descendentes holandeses, como também devido a fatores como a presença de produtores que chegaram a trabalhar em propriedades de holandeses e que depois conseguiram montar seu próprio negócio, ou até mesmo, produtores brasileiros da localidade que migraram para o cultivo de flores (MARQUES; CAIXETA FILHO, 2002)

\subsubsection{O município de Holambra}

Criado em 30 de dezembro de 1991, o município de Holambra tem sua origem estreitamente relacionada à colonização holandesa que se estabeleceu nessa região ao final da década de 1940, quando o governo holandês incentivou a emigração para diversos países e dentre eles o Brasil (BRAGA, 2002).

Inserido numa área de 6.500 hectares (cerca de 1.500 hectares a mais do que o montante colocado à disposição dos primeiros imigrantes holandeses) ocupa uma área que antes pertencia aos municípios de Santo Antonio de Posse, Jaguariúna, Arthur Nogueira e Cosmópolis (WINJEN, 1998; BRAGA,2002). Dista 155 kilômetros da capital, tem como principal via de acesso a rodovia SP-340 (SEADE, 2003).

Integrante da Região Metropolitana de Campinas, Holambra é o menor município e aquele que apresenta a melhor qualidade de vida dessa Região e o $24^{\circ}$ no ranking paulista. Com cerca de oito mil habitantes (7.567 residentes) em 2002, segundo dados de SEADE, (2003), a maioria descendente de holandeses.

Segundo Braga (2002), o município apresenta tendências contrárias as da Região Metropolitana de Campinas e também do próprio Estado, no que se refere à população rural: nesse município houve um crescimento relativo da população rural nos últimos dez anos, em relação à população urbana, que de certa maneira reforça a importância desse setor para economia local.

Holambra é um município que depende efetivamente das atividades agropecuárias (SEADE, 2003) apesar do estudo realizado por Braga (2002) relatar que entre 1996 e 1997 houve uma abrupta queda do valor adicionado da agricultura 
em relação ao comércio. Isso mostra uma estrutura produtiva que tende suas bases para o comercio acompanhando de uma crescente tendência no crescimento do valor agregado desse tipo de serviço. Essa autora destaca ainda que outros serviços e o setor industrial ainda permanecem com pouca expressão no valor adicionado gerado em Holambra e que isso se deve, principalmente, ao fortalecimento do sistema Veiling de comercialização e ao fato de que houve associado a isso uma mudança nos critérios de classificação no valor adicionado de atividades que antes eram consideradas agrícolas e passaram a ser consideradas como comércio atacadista. Além disso, a autora relata a crise financeira que atingiu parte dos produtores de plantas e flores no final dos anos 1990.

Mesmo assim, a o agronegócio de flores no município, constitui o outro pilar de sua estrutura econômica e sem dúvida é a mais importante. Segundo Braga (2002) este é o grande empregador do município, sendo responsável por cerca de $60 \%$ do total de empregos gerados na cidade. Segundo esse estudo, as atividades de "horticultura e produtos de viveiros" responderam sozinha por 41,52\% dos empregos em 1998, seguidas por "outras atividades associativas", que no caso estava representada por três associações de comercialização de flores, com $11,08 \%$, seguidas pela "atividade de serviços relacionados à agricultura" com 9,8\%. Além disso, nesse estudo, Braga (2002) descreve que além das três associações de comercialização de plantas e flores, há um grupo de aproximadamente 180 atacadistas envolvidos com atividades correlatas ao setor, reforçando ainda mais a importância desse setor para a economia local.

A força desse negócio no município de Holambra data da chegada dos holandeses a região, uma vez que a floricultura era uma das culturas previstas para o cultivo desses imigrantes quando ali chegaram em 1948. O cultivo de flores teve seu maior impulso no final de década de 1950 e mais tarde veio a se consolidar numa "máquina inovadora do processo de desenvolvimento de Holambra" segundo palavras de Winjen (1998). Os floricultores de Holambra criaram uma associação com vários propósitos, dentre os quais a promoção do sistema coletivo de vendas e a introdução do modelo holandês de leilões, denominado veiling.

No ano de sua criação, em 1998, esse leilão atingiu a marca de U\$ 7 milhões em seu faturamento anual, sendo que no ano seguinte esse valor dobrou. Atualmente esse leilão é o maior ponto de venda e distribuição de flores e plantas do 
Brasil aonde se acopla um sistema de empresas de transporte exclusivo para o setor (BRAGA, 2002). Neste estudo ainda é possível verificar que o setor de serviços, mesmo apresentando pouca significância em termos de valor agregado (a exceção do comércio atacadista de flores), juntamente com o setor industrial, apresenta uma tendência de crescimento, principalmente naqueles relacionado ao agronegócio de flores.

Além desse sistema de leilão, a associação dos produtores de flores reuniu os atores desse setor, estruturando um verdadeiro pólo de conhecimento técnico (baseado principalmente no desenvolvimento conjunto de tecnologia com parceiros da Holanda) associado a atividades de promoção técnica e comercial. Essas atividades acabaram por ganhar importância crescente que ajuda a impulsionar a área de turismo do município, que hoje já tem o status de "estância turística" e que Ihe garante algumas vantagens em termos de investimentos estatais.

A cidade tem hoje um setor turismo estreitamente relacionado ao negócio de flores e à imigração holandesa, pois os grandes atrativos da cidade são a produção de flores, as características próprias da arquitetura holandesa, as festas e eventos relacionados a esses temas. Dentre os eventos realizados ao longo do ano, o mais importante é a Expoflora, que se caracteriza na maior exposição e venda de flores do Brasil, que ocorre em setembro e que só em 2004, segundo dados da prefeitura municipal, atraiu um publico de mais de 350 mil pessoas. Concomitantemente a exposição e comercialização de plantas e flores, ocorrem atividades gastronômicas, culturais e folclóricas de caráter holandês.

Além desse evento, ocorre também outros eventos técnicos e culturais, como a Hortitec, Enflor, Trekker Trek, Zeskamp, Festa de São Nicolau. Dentre todos esses eventos, a Hortitec se caracteriza por ser o principal evento com caráter nacional e internacional realizado no Brasil, dedicado ao cultivo protegido e às culturas intensivas. Em sua $13^{a}$ edição, no ano de 2006, esse evento congregou cerca de 300 empresas e 18.500 visitantes. 


\subsubsection{A Influência da Cooperativa Agropecuária de Holambra nos agronegócios do município}

Fundada em 05 de junho de 1948 por imigrantes holandeses, a Cooperativa Agropecuária de Holambra, desde seu início foi pautada por uma grande diversidade de atividades de produção agropecuária, como cereais, citros, flores, aves e suínos, alcançado em alguns casos o processo de beneficiamento de alguns desses produtos.

Até meados de 1988, essa cooperativa apresentava uma estrutura organizacional comum às cooperativas agrícolas da época, mas que com o passar do tempo, foi se tornando cada vez mais complexa, na medida em que a cooperativa ia crescendo (SANTOS, 1993). Sob essa estrutura, aplicava-se um modelo gerencial extremamente centralizado, onde a Cooperativa além de participar de todos os processos de produção até a comercialização de seus produtos, mantinha uma forte atuação social junto aos seus cooperados, garantido a eles educação fundamental, telefone, energia elétrica, pavimentação de estradas, etc. gastando elevadas somas de dinheiro para tanto.

No período de 1980 a 1990, o setor de flores e plantas apresentava sucessivos resultados ruins de desempenho, principalmente aqueles relativos ao $1^{\circ}$ semestre de 1987. Tornava-se necessário então mudanças urgentes neste setor e por isso, a cooperativa tomou a decisão estratégica de trabalhar na direção de um leilão no estilo holandês, o Veiling (RIETJENS,2002).

Além disso, a década de 1980 se iniciava com a necessidade de que a Cooperativa buscasse um modelo de gestão mais enxuto e mais flexível, com linhas de comando diretas e curtas, dando mais dinamismo, agilidade ao modelo inchado e centralizador de outrora. Partiu-se então para a desverticalização das atividades através de processos de terceirização ou mesmo abandono das atividades consideradas não essenciais e para a criação de unidades de negócios. Aliado a esse processo, houve uma diminuição do quadro de funcionários, em cerca de $60 \%$. A reestruturação que deu origem as Unidades de Negócios (Unes) teve profundas conseqüências no modus operandi da empresa como um todo e para seus diretores e gerentes em termos de conceitos e práticas típicas da estrutura organizacional anterior (RIETJENS,2002). 
Além das unidades de negócios, foram implantadas também algumas unidades de serviços como: informática, financeira e banco. As unidades de negócio apresentaram um comportamento muito diferenciado no decorrer do tempo, não só explicável pelo desempenho de cada produto/mercado, mas também pelas capacidades gerenciais a que estas estavam submetidas. Outra característica importante que também explica parcialmente o desempenho das unidades de negócios, foi o modelo de gestão adotado nessas unidades, baseado no modelo global de cooperativa. Segundo SANTOS (1993) esse sistema de administração apresentava uma falta de poder real aos seus gestores, que desestimulou o bom funcionamento das unidades, pois diminuía muito o interesse em dedicar-se às unidades, o que por sua vez levou a um descontentamento muito grande no meio dos sócios.

Diante desse cenário, caracterizado pela extensa pulverização dos negócios, com falta de controle efetivo e de acompanhamento pelos sócios, aliado ao despreparo da maioria dos diretores e da complexidade do sistema, a Cooperativa Agropecuária de Holambra uniu algumas das unidades de negócio. Em 1993, surgiram então as áreas: vegetal, animal e de planejamento, cada uma englobando uma parte das unidades de negócios e de serviços. Entretanto esta última estruturação não conseguiu impor à cooperativa, um nível competitivo de desempenho de seus negócios. (RIETJENS,2002).

Assim, caminhou-se para o desmembramento em quatro novas cooperativas, ligadas a Cooperativa Agropecuária de Holambra, como uma cooperativa central (até sua plena liquidação). Assim foi criada a Cooperativa Veiling Holambra (CVH) em 01 de julho de 2001, a Cooperativa de Insumos (SCAIH) em 01 de abril de 2002 e por ultimo a Cooperativa Pecuária Holambra (CPH) em 01 de junho de 2002, concluindo então esse processo de desmembramento (RIETJENS, 2002)

Ainda existe um expressivo grau de interação e de participação dos negócios associados às cooperativas oriundas da Cooperativa Agropecuária de Holambra no contexto dos negócios realizados no município de Holambra e vizinhança, evidenciando a forte influencia dessa cooperativa no contexto sócio, econômico e cultural do município. 


\subsection{A LOCALIDADE DE MOGI DAS CRUZES}

A Localidade de Mogi das Cruzes considerada no presente estudo, engloba os principais municípios produtores de flores da região, compreendida pelos municípios de Guarulhos, Santa Izabel, Arujá, Itaquaquecetuba, Mogi das Cruzes e Guararema. Congrega uma área geográfica extensa cerca de 90 unidades agrícolas de produção, relacionadas à floricultura. A maioria desses municípios apresenta identidade histórica e cultural relacionada à imigração japonesa e à presença marcante da Cooperativa Agrícola de Cotia - Cooperativa Central, atualmente em processo de liquidação judicial.

Diferentemente da localidade de Holambra, não existe para essa localidade um município que atue fortemente com o caráter centralizador das atividades de produção, comercialização e desenvolvimento tecnológico na área de flores e plantas ornamentais.

Além do Município de Mogi das Cruzes, o maior e mais importante em termos socioeconômicos da região, nesta localidade existem atualmente dois municípios que vêm se destacando como agentes importantes na criação de valores para o agronegócio de flores local: Arujá e Itaquaquecetuba. São municípios geograficamente muito próximos e que apresentam boa estrutura viária às proximidades das Rodovias Presidente Dutra (BR 116) e Rodovia Ayrton Senna (SP070).

Em Arujá está sediada a AFLORD - Associação dos Floricultores da Região da Via Dutra, uma importante (e atualmente a única) associação de floricultores da região.

No município de Itaquaquecetuba está sediada a única cooperativa de floricultores da região: a SPFLORES. Esta cooperativa surgiu da necessidade identificada pelos associados da AFLORD em melhorar suas condições de comercialização e acesso aos grandes mercados. A cooperativa conta hoje com cerca de 119 produtores (SPFLORES, 2006), na grande maioria são também associados da AFLORD. A cooperativa traz como diferencial a promoção de cursos específicos para capacitação técnica em arranjos florais e uma equipe técnica 
especializada para acompanhar o desenvolvimento das atividades de seus principais clientes.

Os fluxos de valores presentes entre esses três principais municípios da localidade, acabam por constituir a base da geração dos valores necessários à manutenção da competitividade na localidade. Esse cenário, acaba por concentrar nesses três municípios, os principais fatores para o desenvolvimento das competências locais de produção e comercialização de flores.

\subsubsection{O Município de Mogi das Cruzes}

O município paulista de Mogi das Cruzes dista da capital 52 quilômetros, tem uma população residente em torno de 350 mil habitantes ocupando uma área de 731 $\mathrm{km}^{2}$. O setor de serviço é o mais importante em termos de geração de emprego, seguido pelo setor de indústrias (que conta com cerca de 300 empresas) e agricultura, que conta com cerca de 2.000 produtores rurais (IBGE, 2003).

Mogi das Cruzes se apresenta como o mais importante município agrícola da região, destacando-se pela produção de hortifrutigranjeiros, com uma produção estimada em 1250 toneldas/dia, das quais cerca de $95 \%$ vai para o mercado paulistano e cerca de $5 \%$ para o mercado fluminense. A maioria dos agricultores (aproximadamente 70\%) apresenta porte micro ou pequeno empresário, cerca de $25 \%$ porte médio e apenas $5 \%$ são produtores rurais de grande porte.

É o terceiro município em área ocupada com floricultura, com cerca de $7 \%$ da área estadual (FRANCISCO et al. 2003a) e o principal produtor de orquídea Dendrobium do país. Atualmente cerca de $90 \%$ da produção é comercializada nos Ceasas de Campinas e São Paulo, o restante, é comercializado pela cooperativa, SP Flores, sediada no município de Itaquaquecetuba (AFLORD, 2006).

No entanto, este município, ao contrário de Holambra, não se mostra capaz de concentrar os principais fatores para geração da competitividade dos negócios de flores da localidade. Apesar da alta produção apresentada pelo município, não existe neste a presença intensiva de agentes de comercialização como há em Holambra, 
cooperativas e agentes de desenvolvimento tecnológico. Neste município é que está localizado o escritório regional do SEBRAE 


\section{CAPÍTULO 5. RESULTADOS DA PESQUISA QUALITATIVA}

Neste capítulo é feita a apresentação dos resultados empíricos dessa pesquisa, obtidos através do instrumento de pesquisa qualitativa. Esta pesquisa foi pautada em entrevistas realizadas com atores das duas localidades, assim classificados: Associações de Produtores Rurais; Cooperativas; Empresas Meio e Entidades de Apoio.

Os resultados obtidos serão apresentados separadamente para as duas localidades. Além disto, um terceiro bloco de entrevistas realizadas com atores externos a localidade, mas importantes dentre do contexto do estudo, é apresentado na terceira seção deste capítulo: Câmara Setorial de Flores e Plantas Ornamentais Companhia de Entrepostos e Armazéns Gerais de São Paulo (CEAGESP).

Com relação aos resultados obtidos nas localidades estudadas, estes serão apresentados em dois momentos. Num primeiro momento, os resultados são apresentados e discutidos em função das categorias de entrevistados, conforme descrição dos roteiros apresentada no Capitulo 3, ou seja: Associações de Produtores Rurais; Cooperativas; Empresas Meio e Entidades de Apoio. Em cada uma dessas categorias, segue a apresentação dos resultados segundo a ordem de blocos, estruturada nos roteiros de pesquisa correspondentes (Anexo A). Num segundo momento é feita a discussão comparativa dos resultados observado nas duas localidades.

Este capítulo se encerra com a discussão referente aos resultados da pesquisa qualitativa, que é desenvolvida em função das proposições apresentadas na descrição metodológica desta tese. Os dados secundários serão utilizados para subsidiar o processo de discussão e análise dos resultados. 


\section{‘5.1. ESTUDO DE CAMPO NA LOCALIDADE DE HOLAMBRA}

Os resultados aqui descritos representam a amostragem de um total de dezenove representantes dos diversos atores da cadeia de flores e plantas ornamentais presentes na localidade de Holambra.

O Quadro 5.1 resume a composição da amostra estudada, em função do numero de grupos considerados e o perfil de seus representantes entrevistados, tendo-se como base os roteiros elaborados conforme apresentado no Capítulo 3.

\section{Quadro 5.1. Composição da Amostra: Holambra}

\begin{tabular}{|c|c|c|c|c|}
\hline \multicolumn{3}{|l|}{ Tipo de organização } & Quantidade & Perfil do(s) Entrevistado(s) \\
\hline \multirow{2}{*}{\multicolumn{3}{|c|}{$\begin{array}{l}\text { Associações de Produtores Rurais } \\
\text { Entidades de apoio }\end{array}$}} & 2 & Diretores \\
\hline & & & 2 & $\begin{array}{l}1 \text { Coordenador } \\
1 \text { Gestor de Projeto }\end{array}$ \\
\hline \multirow{2}{*}{$\begin{array}{l}\text { Cooperativas de } \\
\text { comercialização } \\
\text { Empresas Meio }\end{array}$} & Produção & e/ou & 3 & $\begin{array}{l}1 \text { Diretor } \\
1 \text { Gerente }\end{array}$ \\
\hline & & & 12 & $\begin{array}{l}\text { Diretores, sócios, técnicos e } \\
\text { gerentes }\end{array}$ \\
\hline
\end{tabular}

Fonte: o autor

\subsubsection{Associações de Produtores Rurais}

Fizeram parte deste estudo, duas das três organizações de produtores rurais existentes na localidade Holambra. A Associação de Agricultores Familiares de Holambra (AAFHOL) e a Associação de Agricultores Familiares de Artur Nogueira (AAFAN). Nas duas associações foram feitas entrevistas com um de seus diretores, que foram gravadas e transcritas posteriormente. 


\subsubsection{Bloco 1 - Caracterização Geral}

As duas associações, AAFHOL e AAFAN, foram constituídas com o objetivo de proporcionar aos seus associados, o acesso à linha de crédito Programa Banco da Terra, promovido pelo Governo Federal.

Apresentam uma estrutura muito reduzida, não contam com nenhum tipo de patrimônio como sede, técnicos para apoio, etc. O quadro de ambas é composto por dez pequenos agricultores que exercem algum tipo de função administrativa da entidade e que não fazem da floricultura, necessariamente sua única atividade agrícola.

O perfil dessas associações é marcado pela carência em infra-estrutura e recursos financeiros. As reuniões da AAFHOL são realizadas semanalmente, quase sempre em um local disponibilizado pela prefeitura local. Já as reuniões da AAFAN, são comumente realizadas na propriedade de algum dos associados, num sistema de rodízio.

Essa falta de estrutura, por um lado dificulta a realização de atividades que consigam promover ações de parceria entre os atores da cadeia ou com agentes de pesquisa, pois nem sempre seus associados ou a própria associação é capaz de prover as condições de contrapartida que os parceiros possam necessitar. Isso dificulta o desenvolvimento freqüente de atividades conjuntas, entre os produtores e os agentes da cadeia de produtiva.

Uma atividade relatada como relevante, que essas associações desenvolvem e que não esta associada ao objetivo maior de sua fundação, é a participação no "Projeto Flores São Paulo", coordenado pelo SEBRAE, descrito adiante (Entidades de Apoio). A freqüência dos contatos estabelecidos junto aos organismos de apoio a produção ou mesmo da gestão dos negócios é para ambas as associações, praticamente inexistente.

Não há qualquer tipo de ingerência sobre seus associados no sentido de determinar ou aconselhar as espécies ou quantidade a ser produzida. Ficou 
evidenciado que esse tipo de decisão é de responsabilidade exclusiva do associado e basicamente definida pela competência e experiência acumulada pelos produtores ao longo dos anos. No que se refere à comercialização dos produtos, em ambas as associações, a totalidade de seus associados, utilizam alguma das cooperativas locais para a comercialização de seus produtos.

\subsubsection{Bloco 2 - Cooperação e Parceria}

Apesar da carência de recursos prejudicar significativamente a possibilidade destas associações desenvolverem outras atividades de apoio à produção e/ou ao desenvolvimento tecnológico de seus cooperados, ambas promovem reuniões freqüentes. Estas reuniões de articulação, em geral abordam temas como financiamento obtidos, questões técnicas e novas possibilidades de mercado. Mesmo que essas reuniões nem sempre resultem em ações específicas, a sua dinâmica e freqüência, promove maior aproximação entre seus membros, sem que sejam necessários significativos esforços por parte das Associações. Além disso, a semelhança de perfil e a equivalência dos propósitos que originaram as duas Associações, já é um fator catalisador, que aumenta também a proximidade entre seus componentes.

A aproximação gerada por essa "prática associativista", em ambas associações, mostra-se fundamental na construção da confiança mútua entre seus membros, segundo relato de ambos diretores entrevistados. Essa confiança por sua vez, assume papel decisivo nas ações de parcerias desenvolvidas por seus associados.

As principais ações de parcerias desenvolvidas pelos produtores e relatadas nas entrevistas, ocorreu ao nível da propriedade rural, independentemente da origem étnica e do tipo de espécies cultivada entre os produtores.

Tanto para o diretor entrevistado na AAFAN como para o diretor da AAFHOL, não existe qualquer favorecimento que a origem étnica possa proporcionar no sentido de fortalecer os laços de confiança entre eles e/ou proporcionar qualquer tipo de ação cooperativa apenas em função disso. Os dois entrevistados mostram convicção em declarar que também não ocorre favorecimento para os cidadãos que 
vivem e/ou trabalham na localidade de Holambra. Para ambos, esse tipo de ação está baseado muito mais no histórico de vida e de atividades conjuntas desenvolvidas, do que necessariamente na origem étnica do individuo ou "vizinhança" (habitar na mesma localidade). No quadro de associados das duas entidades, a presença de descendentes de holandeses é minoritária.

Apesar da grande maioria das ações conjuntas de cooperação se desenvolverem com maior freqüência entre os membros de uma mesma associação, essas ações também podem envolver produtores sem vínculo a qualquer uma das duas associações. Nenhum dos entrevistados, no entanto, foi capaz de mensurar se o nível desse tipo de ação é maior entre os seus associados do que quando comparado a produtores não associados. O diretor da AAFHOL manifestou que o estreitamento dos laços de convivência entre os membros da associação reflete em uma maior freqüência de ações conjuntas entre seus associados, quando comparadas ao mesmo tipo de ações desenvolvidas com outros produtores.

Em termos gerais, os dois entrevistados destacaram com principais razões para o desenvolvimento de ações conjuntas: o compartilhamento de idéias (técnicas, organizacionais, etc), a troca de informações e a participação em feiras e eventos similares. Ocasionalmente, ações voltadas para o compartilhamento de equipamentos de produção, realização de dias de campo e a discussão de novidades tecnológicas, também podem dar origem ao desenvolvimento de ações conjuntas.

Com relação às ações conjuntas desenvolvidas com a presença de organizações (que não as unidades agrícolas de produção), ambos os entrevistados mostram que esse tipo de ação é rara e até mesmo inexistente com alguns organismos de governo, como SEBRAE, SENAR e CATI. Mesmo fazendo parte do programa "Flores São Paulo", citado anteriormente, as duas associações classificam como fraca a intensidade das ações de parceria desenvolvidas com o SEBRAE.

\subsubsection{Bloco 3 - Localidade}

Tanto o diretor da associação de Holambra como o de Arthur Nogueira foram unânimes em afirmar que estar inserido no contexto da localidade, acaba por 
proporcionar vantagens competitivas que, em termos genéricos, consideram ser superiores àqueles que poderiam obter se estivessem localizados em outra região.

Ambos consideram que suas respectivas regiões apresentam excelência na produção e comercialização de flores e plantas ornamentais. No entanto, o diretor da AAFHOL foi cauteloso em classificar a localidade de Holambra como sendo a mais importante da floricultura no Brasil. Apesar de considerarem que em termos de comercialização, só o volume trabalhado pela Cooperativa Veiling de Holambra justifica a destacada importância com relação a outras regiões do Brasil, ressalta que com relação ao fator produção, não acha ser pertinente esse tipo de classificação. Para ambos, não existe no Brasil uma única região capaz de produzir todas as espécies hoje cultivadas, em volume condizente capaz de lhe atribuir o titulo de região mais importante em termos de produção.

Para os dois diretores entrevistados é comum a percepção de que localidade cria condições que propícia um melhor acesso à matéria-prima e ao mercado consumidor, uma vez que traz facilidades para a comercialização e distribuição dos produtos de seus associados.

Especificamente para 0 diretor da AAFAN, essas facilidades são indiretamente geradas pela localidade e diretamente geradas pelas cooperativas de comercialização nela presentes. Apesar de estar localizada próximo aos grandes centros como São Paulo e Campinas (principalmente), isso não garante o melhor acesso ao mercado consumidor, uma vez que esse acesso seria via CEASA/CEAGESP que nem sempre é sinônimo de garantia de venda. Ainda segundo esse entrevistado, o papel desempenhado pelas cooperativas é relevante, pois além de melhor distribuírem os produtos, oferece maiores garantias de venda. Considera que a ação dessas cooperativas é fortemente fortalecida pelas condições históricas e culturais da região, vinculada à imigração holandesa e a forte prática cooperativista. Em síntese, o diretor da AAFAN atribuiu maior importância à localidade.

O diretor da AAFHOL foi enfático ao reforçar que não seria possível aos seus associados vender para grandes atacadistas, supermercados, etc. se não fosse por intermédio da cooperativa. O volume e o mix de produtos gerado por vários produtores são os principais fatores para isso.

Apesar de existir na localidade uma cooperativa específica para a compra de insumos agropecuários, o perfil dos produtores dessa organização não lhes garante 
o preenchimento dos requisitos necessários para a participação nessa cooperativa de insumos. Segundo o diretor da AAFHOL, o nível de organização e consolidação das praticas associativistas atingido por sua associação, permite a formação de um grupo específico para efetuar a compra conjunta de insumos. A construção desta estrutura de compra conjunta de insumos deve contar também com os produtores associados da AAFAN e outros cujo perfil também os impede de se associarem à cooperativa de insumos.

Para o diretor da AAFHOL, a associação identificou que seu nível de organização atual não justifica seu posicionamento inferior frente à maioria de seus fornecedores no processo de compra de insumos, máquinas e equipamentos de infra-estrutura. O entrevistado argumenta ainda que o ambiente proporcionado pela comercialização via cooperativa diminui drasticamente o poder de negociação dos clientes. Finalmente, ele conclui que as práticas associativistas aumentam o poder de barganha na cadeia tanto a montante como a jusante.

Os entrevistados de ambas as associações também são enfaticamente concordantes quanto à percepção de que existe um ambiente propício para a aproximação dos produtores, possibilitando a criação de parcerias das quais muitas vezes pode surgir o desenvolvimento de novas técnicas de produção. No caso dos membros dessas associações, nem sempre este desenvolvimento está relacionado ao incremento tecnológico e sim a melhorias e/ou adaptações de determinados processos ou formas de desenvolvimento dos processos de comercialização, cultivo, colheita e armazenagem dos produtos. Essa aproximação também foi vista pelos representantes das duas Associações, como uma maneira de melhorar o nível da mão-de-obra local, uma vez que o aprendizado é repassado entre os produtores. Em outras palavras, significa dizer que as ações de cooperação entre os produtores locais favorecem a construção de competências específicas à localidade. No entanto, para ambas as associações, a oferta de mão-de-obra especializada na localidade, ainda é escassa na região.

Também para ambos entrevistados, a localidade não dificulta a entrada de novos atores aos negócios locais e também não enxergam isso como um problema ao desenvolvimento dos negócios locais.

Tanto 0 diretor da AAFHOL quanto 0 da AAFAN, apresentaram comportamento semelhante, no tocante à percepção das vantagens/desvantagens proporcionada pela localidade no desempenho dos negócios de seus associados. 
Estes diretores não observam qualquer indicio de que possa haver algum tipo de saturação das possibilidades produtivas ou de comercialização na localidade. Para eles, o fato da Cooperativa Veiling de Holambra estar projetando a mudança de suas instalações físicas de comercialização para o Município de Santo Antonio de Posse, mostra que a localidade ainda está distante de qualquer tipo de estrangulamento da estrutura local. Ambos expandem essa análise para a questão produtiva, pois afirmam que a grande maioria dos produtores da região, incluindo os pertencentes a essas duas associações, ainda consegue absorver um aumento significativo na demanda de produção.

Quanto ao papel do governo local, houve discordância acentuada frente à percepção dos respondentes das duas associações. O entrevistado da AAFAN, percebe o governo local muito pouco atuante no sentido de promover os agronegócios locais, mesmo sendo a floricultura o negócio mais presente em toda a região e responsável pelo desenvolvimento de outros de negócios, à exemplo do turismo local. Para ele, a relação que esta associação estabelece com o poder local no sentido de promover atividades que impulsionem os negócios de seus associados é tida como praticamente nula. Já para o diretor entrevistado na AAFHOL, o governo local (em todas as suas instâncias) poderia ser bem mais ágil, o que não significa que este seja totalmente ausente. Esse diretor relatou que algumas ações são desenvolvidas, mas muito pouco relacionadas diretamente à produção e a comercialização de flores. Finalmente, o entrevistado da AAFHOL reconhece que a associação deveria ser mais atuante no sentido de propor algumas ações e cobrar outras do poder local.

\subsubsection{Bloco 4 - Inovação e Informações}

Para os entrevistados das duas associações estudadas, as inovações podem ser observadas em quase todos os aspectos relacionados às técnicas de plantio e manejo das plantas. Com relação aos aspectos de comercialização, ambos destacaram que a instituição do leilão no Veiling, que apesar de não ser uma 
novidade no comércio holandês, no Brasil inovou o processo de comercialização de flores e plantas, tornando-o muito mais ágil e transparente ${ }^{6}$

Os diretores da AAFHOL e da AAFAN foram unânimes em enfatizar que é extremamente difícil para os pequenos agricultores acompanharem 0 desenvolvimento tecnológico do setor, dada as carências estruturais e financeiras que apresenta a maioria desses produtores. A participação em feiras, como a $\mathrm{AGRIFAM}^{7}$ é uma das estratégias utilizadas por ambas associações para ter acesso à tecnologia mais compatível ao perfil de seus associados.

No que se refere às principais fontes de informação capazes de contribuir para a geração de novos conhecimentos na área de seus negócios, ambos entrevistados identificaram como importantes: visitas a empresas e/ou outras propriedades, as entidades de apoio (SEBRAE, SENAR, etc.), os fornecedores de máquinas e insumos, consultores especializados, participação em feiras e principalmente os clientes. Entretanto, eles argumentam que na pratica cotidiana da maioria de seus associados essas fontes são bem pouco expressivas, uma vez que eles se acham distantes das entidades de apoio e do poder público. Alertam ainda que pelo fato de serem produtores de pequeno porte e de baixo potencial de absorção tecnológica, não são freqüentemente abordados pelos representantes de fornecedores.

Sendo assim, na percepção dos representantes das duas associações, as fontes de informação que mais se aplicam a sua prática diária se concentram na troca de informações com outros produtores, em conversas informais e na participação de feiras e eventos similares.

\subsubsection{Bloco 5 - Gestão e Estratégias}

Os diretores da AAFHOL e da AAFAN apresentam uma visão geral dos negócios de seus associados, focada nas questões técnicas de produção e do

\footnotetext{
${ }^{6} \mathrm{O}$ sistema é baseado em um relógio, também conhecido como Klok, que mostra todas as informações referentes ao produto no momento da venda, permitindo a comercialização de grandes quantidades e variedades de produtos em um curto espaço de tempo. A média é de um lote é adquirido a cada 1,8 segundos.Maiores informações em http:Ilwww.veiling.com.br

${ }^{7}$ Feira anual volta aos pequenos produtores
} 
comércio local. Os entrevistados não vêem a possibilidade de alcançar mercados externos.

Segundo os entrevistados, o fato de seus associados destinarem grande parte de sua produção para agentes de comercialização (no caso as cooperativas) acaba por distanciá-los de uma efetiva identificação de seus principais clientes. Em linhas gerais mostram ter idéia de quem sejam os principais clientes de seus associados, porém essas informações são condicionadas aos agentes de comercialização.

Ambos representantes das associações são concordantes em considerarem que a qualidade, entrega pontual e o preço são fatores determinantes para o sucesso dos negócios de seus associados. No entanto, alertam para a inexistência de um padrão de qualidade para setor de flores e plantas ornamentais. Cada agente (cooperativa) estabelece seu próprio padrão de qualidade que deve ser seguido pelos cooperados. Isso faz com que o sucesso dos negócios de seus associados esteja numa intensa relação de dependência desses agentes de comercialização e isso, para ambos, não é um aspecto necessariamente negativo. Os respondentes argumentam que existem várias vantagens também, como aumento no poder de barganha junto aos clientes, diminuição do risco financeiro do negócio e melhor disposição dos produtos por parte desses agentes. Por outro lado, destacam que esse papel deve ser exercido por entidades gerenciadas pelos próprios produtores (como as cooperativas ou mesmo associações específicas) e que para tanto, os princípios do associativismo e a doutrina cooperativista devem ser a pedra fundamental deste processo, mesmo que a aplicação plena desses princípios seja um desafio e um constante processo de aprendizado para os envolvidos.

\subsubsection{Entidades de Apoio}

Foram entrevistados no presente estudo, o coordenador da Associação Comercial e Empresarial (ACE) de Holambra e a gestora do "Projeto Flores São Paulo“, desenvolvido pelo SEBRAE, doravante denominados apenas "coordenador" e "gestora". 


\subsubsection{Bloco 1 - Caracterização Geral}

A Associação Comercial e Empresarial de Holambra foi fundada em 1993 e conta com mais de 150 empresas associadas, das quais cerca de 15\% relacionadas diretamente aos negócios de flores e plantas ornamentais.

Com relação ao SEBRAE, desde janeiro de 2006 essa entidade desenvolve em Campinas e região, o projeto "FLORES SÃO PAULO”, em parceria com cerca de 20 empresas e entidades locais que atuam na cadeia de flores. O objetivo deste projeto é aumentar o consumo de flores e plantas ornamentais.

Apesar de serem duas entidades não direcionadas exclusivamente ao agronegócio de flores, ambas se consideram atuantes no sentido de promover o desenvolvimento desta atividade na localidade, além de contribuir para a construção de públicas para o setor. Dentre as atividades que consideram ter mais destaque no papel por elas desempenhado, seus representantes são enfáticos em relacionar seus respectivos papéis como indutores de ações de parceria entre os atores do sistema agroindustrial de flores e plantas ornamentais.

Segundo o coordenador entrevistado, a ACE-HOLAMBRA se destaca pela intensa assessoria jurídica e administrativa que fornece aos seus associados enquanto a gestora enfatiza que o SEBRAE, na localidade, tem se destacado na promoção de cursos para produtores rurais e no acesso a linhas de crédito.

\subsubsection{Bloco 2 - Cooperação e Parceria}

Quanto à percepção sobre as ações de cooperação e parceria, os representantes de ambas entidades apresentam uma percepção bastante distinta. Enquanto a gestora demonstra perceber que os produtores rurais desenvolvem parcerias entre si, independentemente das espécies que cultivam, o coordenador da ACE-HOLAMBRA apontou não haver nenhum tipo de parceria relacionada as atividades de produção. Segundo esse coordenador, as parcerias desenvolvidas pelos produtores da localidade estão mais relacionadas à ações de mercado e de capacitação técnica. 
Independentemente dos objetivos identificados nas parcerias estabelecidas, para os entrevistados de ambas as entidades, o principal fator considerado no estabelecimento desse tipo de ação está relacionado ao aumento da confiança entre os atores, oriunda da consolidação das relações de negócio ao longo do tempo. Nenhuma dessas entidades considera que os laços familiares sejam fatores decisivos para o desenvolvimento dessas ações. Não obstante, ambos reconhecem que, apesar de não interferir decisivamente no processo, a identidade étnica exerce influência mesmo que fraca no desenvolvimento dessas ações.

\subsubsection{Bloco 3 - Localidade}

A concentração dos produtores e de outras empresas na localidade de Holambra é vantajosa quando comparada à possibilidade de estarem localizados em outra região, afirmam o coordenador e a gestora. O maior acesso ao mercado consumidor e a maior facilidade de comercialização dos produtos gerados na localidade, são dois pontos vantajosos também destacados por ambos. Além disso, destacam que a localidade favorece o trabalho de suas entidades e de outras similares, como SENAR, por exemplo.

Apesar de considerarem que a localidade de Holambra seja um pólo de excelência em cultivo protegido, produção e comercialização, além de concentrar excelentes especialistas nessas áreas, não há um consenso entre ambos de que essa seja a região mais importante para dos agronegócios paulistas de flores e plantas ornamentais.

Embora os dois entrevistados considerem que a geração de conhecimento e tecnologia são fatores fundamentais para o sucesso dos negócios da floricultura em geral e que grande parte desse conhecimento seja gerado e/ou repassado para os demais atores da cadeia, via localidade de Holambra, para a gestora do projeto "Flores São Paulo", esta importância magna fica restrita à comercialização. Para ela, a floricultura tem especificidades que trazem vantagens em alguns pontos para a Região de Mogi das Cruzes, outras para a região de Atibaia e outras para a Região de Holambra. Alguma espécie importante para o contexto estadual da floricultura, não tem em Holambra seus maiores especialistas ou grande parte de sua produção. 
Já o coordenador da ACE-HOLAMBRA discorda, alegando que os motivos já relacionados são capazes de conferir a esta localidade o caráter de mais importante em termos gerais para o Estado de São Paulo.

Como relação as vantagens e desvantagens apresentadas pela localidade, os dois entrevistados mostram percepções bastante distintas. Se por um lado, o coordenador já aponta para sinais na localidade de aumento das rivalidades e dos conflitos entre os concorrentes, associado a uma pressão nos custos de produção para cima, a gestora julga que na localidade de Holambra tais problemas ainda não estejam se manifestando. $O$ coordenador da ACE vai mais além e aponta para dificuldades futuras de circulação do transito local e distribuição dos produtos.

Com relação ao papel do poder local no tocante à promoção dos negócios de flores e plantas, ambos não manifestaram opinião sobre o assunto.

\subsubsection{Bloco 4 - Inovação e Informações}

A percepção dos dois entrevistados no que se refere à inovação no contexto dos agronegócios de flores e plantas também se mostrou divergente.

Apesar da gestora ter identificado que a inovação possa estar associada aos diversos fatores destacados no roteiro de pesquisa, ela não consegui identificar quais seriam os principais fatores específicos que poderiam estar associados a desenvolvimento de processos inovativos nas unidades agrícolas de produção ou em qualquer outro agente que atue nessa cadeia. Já para o coordenador, a inovação no ambiente da floricultura local está especificamente associada ao desenvolvimento de novas variedades de flores e técnicas de cultivo.

Com relação às principais fontes de informação capazes de contribuir para a estruturação dos pilares competitivos da localidade, os entrevistados relatam que o papel desenvolvido pelas entidades que representam, somado ao de outras entidades similares como SENAR, centros de tecnologia, etc. é importante na geração e disponibilização de informações. Além disso, ambos também destacam a participação em feiras e eventos similares, além da troca de informações entre produtores e outros agentes da cadeia, como importantes fontes de informação. A gestora destaca ainda a presença de revistas e demais publicações especializadas 
no setor, também como fontes de extrema importância na geração de informações relevantes. Finalmente, o coordenador destaca o papel do cliente nesse processo, pois considera que nos clientes residem as principais informações capazes de orientar o desenvolvimento de todas as outras atividades desenvolvidas ao longo da cadeia produtiva, o que deve ser mais bem considerado pelos atores locais.

\subsubsection{Bloco 5 - Gestão e Estratégias}

Considerando o papel desempenhado por essas entidades pesquisadas no que concerne à busca e ao preparo do empresariado local para conquistar novos mercados, foi possível observar que os dois entrevistados manifestaram a mesma visão sobre a potencialidade crescente do mercado para o agronegócio de flores da localidade, indo de encontro ao que considera o IBRAFLOR (2006). No entanto, com relação ao mercado internacional, somente o coordenador se manifestou, apontando para o mesmo sentido de crescimento. Associado a esse aspecto mercadológico, para ambas entidades, o acesso a esse mercado potencial é dificultado.

Para os dois entrevistados, a qualidade foi considerada como sendo o principal fator de sucesso para os negócios de flores e plantas ornamentais. À semelhança do resultado obtido com as Associações de Produtores Rurais, ambos destacam que não existe uma padronização da qualidade das flores e plantas ornamentais produzidas e/ou comercializadas na localidade, desta forma cada agente de comercialização apresenta seu próprio padrão de comercialização, em função das exigências de seu mercado.

A busca por melhores condições competitivas se constitui um dos principais objetivos das associações de apoio, principalmente aquelas aqui estudadas. Nesse sentido, investigou-se a percepção de ambos frente à importância da concentração geográfica de produtores e demais atores da cadeia de produção como fonte de criação de vantagem competitiva para a localidade de Holambra. Segundo o coordenador, essa forma de arranjo é de suma importância nesse processo, enquanto que para a gestora, apesar de identificar a concentração como relevante, não atribuiu o mesmo grau de importância do coordenador. 
A presença de um agente de coordenação na cadeia produtiva foi um outro fator importante para a construção de uma base competitiva na localidade, identificado pelos entrevistados. Além desse fator, a presença de organizações cooperativas e da cultura cooperativista também foi relatada por ambos como fatores fundamentais na construção da base competitiva local.

Os entrevistados destacam a grande importância da participação em eventos técnicos. Para eles, esse tipo de evento traz a possibilidade de divulgação da marca e dos produtos, além de propiciar a criação de parcerias e cooperação através da maior aproximação com outras empresas. Adicionalmente, as empresas participantes, dos eventos conhecerem o que está sendo oferecido por seus concorrentes. Finalmente, os entrevistados destacam que este tipo de evento é capaz de promover a abertura de novos mercados e a consolidação de novos negócios.

\subsubsection{Cooperativa}

A obtenção dos dados qualitativos relacionados ao roteiro especifica para as organizações cooperativas foi feita na maior cooperativa da localidade, a Cooperativa Veiling de Holambra $(\mathrm{CVH})$, em entrevista com um representante do corpo gerencial e um diretor, doravante denominados apenas "gerente" e "diretor". Os resultados aqui apresentados são oriundos da compilação dessas entrevistas.

\subsubsection{Bloco 1 - Caracterização Geral}

A cooperativa conta com cerca de 250 socio-cooperados e cerca de 270 empregados fixos. Atualmente é responsável por aproximadamente $40 \%$ da comercialização nacional, oriunda de 313 produtores (além dos cooperados o Veiling trabalha com produtores não-cooperados).

Essa cooperativa conta com produtores em todos os municípios componentes da localidade de Holambra aqui estudada, além de produtores pertencentes a outros 
municípios. Alguns estão sediados em municípios tradicionalmente importantes no cultivo de flores e plantas ornamentais, como Atibaia, Arujá, Ibiúna e Paranapanema, todos no Estado de São Paulo. Outros, em municípios menos tradicionais como municípios de Munhoz e Andradas em Minas Gerais e Maceió em Alagoas. Seus produtos são sempre comercializados com a própria marca do Veiling e da localidade de Holambra.

O fato de trabalhar com produtores não-cooperados em parte se relaciona à necessidade da cooperativa em atender as demandas não supridas por seus cooperados e por outra para atender à necessidades de mercado, associadas à formação de mix. No entanto, esses fornecedores não superam os cooperados em número e em quantidade de produtos comercializados. Apesar dos produtores cooperados e os não-cooperados estarem submetidos às mesmas regras de comercialização, para os não-cooperados, os custos da cooperativa e outros impostos são maiores. Além disso, esses fornecedores não podem fazer parte do processo de gestão da cooperativa.

O foco de atuação dessa cooperativa é a distribuição atacadista, cujos resultados obtidos ao longo de sua história permitem aos seus diretores enfatizarem que a cooperativa comercializa e distribui seus produtos de maneira mais eficiente do que se os produtores fizessem isso sozinhos.

Além de dar prioridade às atividades de comercialização e distribuição a cooperativa também atua, de maneira menos efetiva, no sentido de promover a participação de seus cooperados em feiras e eventos relacionados aos seus negócios e em outras áreas que ajudam a promover o desenvolvimento dos agronegócios de flores de seus cooperados.

A Cooperativa comercializa cerca de $70 \%$ de seus produtos diretamente para atacadistas e o restante para hipermercados. Desse total, mais de $90 \%$ se destina ao mercado nacional, sendo que o restante pode ser destinado a mercados internacionais, prioritariamente para paises europeus, como Holanda e Alemanha, mas também para os Estados Unidos da América. 


\subsubsection{Bloco 2 - Cooperação e Parceria}

A disposição da cooperativa em estabelecer ações conjuntas com diversos setores relacionados à cadeia produtiva de flores e plantas ornamentais é enfaticamente destacada. $\mathrm{Na}$ visão de ambos entrevistados da $\mathrm{CVH}, \quad$ o desenvolvimento de ações conjuntas é um fator importante para a promoção da estrutura competitiva dos negócios da localidade.

A Cooperativa já apresenta um histórico no desenvolvimento de vários tipos de parcerias, que na maioria dos casos, estavam relacionadas a atividades de comercialização e distribuição. No entanto, também já desenvolveu atividades em parceria com Institutos de pesquisa como Instituto Agronômico de Campinas - IAC e a Empresa Brasileira de Pesquisa Agropecuária - EMBRAPA. É associada ao Instituto Brasileiro de Floricultura - IBRAFLOR e por ocasião das entrevistas, estava em processo de discussão interna entre diretores e conselheiros, sobre sua eventual participação no "Projeto Flores São Paulo", citado anteriormente.

Com relação à participação da Cooperativa em associações ou outras cooperativas, apesar de fazer parte do quadro associativo da ACE-HOLAMBRA, não busca com freqüência os serviços que essa entidade oferece, uma vez que sua estrutura administrativa the fornece todo o suporte necessário para o pleno desenvolvimento de seus negócios.

No que concerne à percepção da cooperativa quanto às ações conjuntas e/ou parcerias desenvolvidas por seus cooperados, foi possível observar uma efetiva congruência de opiniões mostrando que esse tipo de ação entre os produtores cooperados independentemente da espécie que esses possam cultivar ocorre, porém não de maneira freqüente. Já com relação a esse tipo de ação com entidades de pesquisa ou órgãos de apoio (técnico ou gerencial), não especificou a freqüência com que essas são desenvolvidas por seus cooperados e nem por quantos deles.

Alguns fatores são identificados como importantes nesse processo, dentre eles destacam-se o conhecimento e a confiança adquirida no processo histórico de relações entre os parceiros. Nesse sentido, apontam que as relações familiares (comuns na localidade) e o convívio com outros cooperados, ajudam a consolidar essas relações de confiança e o conhecimento mútuo. Essas relações são em parte 
incentivadas pela própria prática cooperativista, que requer um convívio maior entre os cooperados por ocasião das assembléias e também pela própria estrutura de funcionamento do leilão Veiling, onde é comum a presença de produtores, acompanhando a evolução dos preços.

No entanto, para a cooperativa, o papel do cooperativismo no desempenho dos negócios da localidade, apesar de importante, não é fundamental para o sucesso dos negócios. A visão geral dos entrevistados mostra que o exercício da doutrina cooperativista em sua essência é muito difícil de ser aplicado na vida cotidiana e assim, associar a essa doutrina o elemento fundamental para o sucesso das atividades locais não seria uma análise real do ambiente. Existe entretanto a certeza de que esse seja um fator importante, mas não decisivo.

Dentre os principais motivos que levam os cooperados a estabelecerem esse tipo de ação conjunta, foram destacados: participação conjunta em feiras e/ou exposições (nacionais ou internacionais), o compartilhamento de idéias e informações (técnicas, organizacionais, etc) e o treinamento de pessoal (cursos, dia de campo).

\subsubsection{Bloco 3 - Localidade}

Para os entrevistados da Cooperativa Veiling Holambra, a localidade de Holambra é um pólo de excelência em produção e comercialização de flores e plantas. Essa excelência no entanto é diferenciada para cada uma das atividades.

No que concerne à produção, está muito mais voltada ao domínio das técnicas relacionadas a grande maioria das espécies, do que com relação ao volume de produção. A análise em função do mercado, para os entrevistados, só tem sentido se for mensurado em relação às espécies cultivadas e nem todas são cultivadas nesta localidade.

No entanto, com relação às atividades de comercio e distribuição, a localidade de Holambra é superior a qualquer outra do território nacional. O fato de contar em seu quadro de associados, com produtores localizados em outros Estados da Federação ou municípios distantes da localidade de Holambra é uma mostra 
consistente de que ali as condições para o desenvolvimento dos negócios são superiores as de outras regiões.

Alguns produtores, antes sediados em outras regiões, já adquiriram propriedades e transfeririam atividades produtivas na localidade, uns em caráter parcial, outros de forma integral. Isso favorece, em termos gerais, o desenvolvimento dos negócios de seus cooperados, quando comparado ao desempenho que os mesmos poderiam ter se estivem fora da localidade.

As percepções dos entrevistados apontam para dois principais fatores, relacionados a essas melhores condições que a localidade proporciona ao desenvolvimento da floricultura:

a) Maior acesso ao mercado consumidor favorecendo a comercialização e distribuição dos produtos, principalmente devido à a proximidade com os grandes centros consumidores e a atividades das cooperativas de comercialização que estão sediadas nesta localidade.

b) As condições sócio-culturais e a presença marcante de cooperativas e associações de produtores, acabam por favorecer da aproximação entre os produtores possibilitando o desenvolvimento de novos produtos e/ou novas técnicas de produção.

A Cooperativa reconhece que a localidade passa hoje por um momento de consolidação de uma nova fase na história do desenvolvimento de suas atividades agrícolas: está se tornando também referência em cultivo protegido, incluindo as atividades de produção de hortaliças. O domínio tecnológico necessário para o cultivo de diferentes espécies de flores, hoje se estendeu também para a produção de hortaliças. O sucesso crescente da Hortitec (onde é expressiva a participação de empresas exclusivamente relacionadas à produção de hortaliças) é destacado como prova disso.

Parte importante das necessidades tecnológicas para a produção de flores e plantas ornamentais é desenvolvida nesta localidade, no entanto, existem outras que são desenvolvidas em centros de pesquisas como IAC e em outros locais do Brasil.

Com relação ao papel desempenhado pelo poder local, a percepção tanto do gerente como do diretor aponta para uma atuação discreta das esferas de poder, inferiores à desejada pelos representantes da cooperativa. Existe apoio a diversas atividades que se encontram mais focadas na divulgação dos produtos e do 
município de Holambra, mas não com relação ao desenvolvimento específico de programas ou projetos voltados ao desenvolvimento das áreas de produção ou comercio local. "Não existe no município de Holambra, por exemplo, um Departamento (equivalente a uma secretaria municipal) específico para a área agrícola ", destaca o Diretor.

O município de Holambra hoje é o grande pólo centralizador de todas as atividades da floricultura que são desenvolvidas na localidade e hoje, segundo percepção dos representantes da cooperativa, é fortemente reconhecido pelos profissionais dos agronegócios pela produção e comercialização de flores e também pelo turismo relacionado a flores e as tradições culturais holandesas.

Como desvantagens associadas à localidade, não foi possível associar algum fator que os entrevistados julgassem destacadamente relevante. Apenas foi realçado pelo Conselheiro, que o município de Holambra já começou a apresentar dificuldades relacionadas à circulação dos veículos de transporte de produtos, além da possibilidade de saturação dos distribuidores locais. Esse foi um dos motivos que justificaram a mudança da sede operacional da Cooperativa para o município vizinho de Santo Antonio de Posse.

\subsubsection{Bloco 4 - Inovação e Informações}

A inovação presente nos negócios locais de flores e plantas, segundo a percepção dos entrevistados da Cooperativa, pode estar associada basicamente aos seguintes fatores:

a) Desenvolvimento de novas variedades;.

b) Técnicas de cultivo e comercialização.

c) Desenvolvimento de máquinas e equipamentos capazes de agilizar o processo de produção.

d) Embalagens para o acondicionamento das flores e plantas.

A implantação do Veiling (clok) também é considerada como uma inovação por ambos, uma vez que o sistema de comercialização na localidade e no Brasil não existia. 
Com relação às fontes de informação capazes de contribuir para a geração de conhecimento e geração das competências locais, forma destacados as seguintes:

a) A importância da participação de seus cooperados em feiras e eventos similares, especialmente aqueles que ocorrem no Brasil e na Holanda. É comum a ida de vários produtores de Holambra, sobretudo aqueles de origem holandesa, em no mínimo uma feira do setor que ocorre anualmente naquele país.

b) A participação em eventos do tipo "Dia de Campo". Esses eventos além de proporcionarem a possibilidade de contato com as novas tecnologias disponíveis, promove a aproximação entre os produtores, permitindo intensa troca de informação entre eles.

c) Contato com os clientes: a cooperativa, mantém um rígido controle dos padrões de qualidade dos produtos oferecidos por seus cooperados, cujos requisitos são em grande parte, identificados diretamente nos clientes.

d) Publicações especializadas.

e) Visitas a outras empresas e propriedades situadas na região ou fora dela, também foram considerados importantes fontes de informação. Nessas ocasiões, além da observação direta das práticas desenvolvidas no local visitado, essas situações permitem a troca de informações com os próprios funcionários que trabalharam nessas empresas e/ou propriedades visitadas.

f) Entidades de apoio (SEBRAE, SENAR, centros de tecnologia)

\subsubsection{Bloco 5 - Gestão e Estratégias}

Para ambos os entrevistados da cooperativa, não há como analisar os resultados obtidos pelos negócios da localidade, de outra forma, sem a presença de uma entidade cooperativa. Desde a vinda dos primeiros imigrantes holandeses para a região, os negócios foram desenvolvidos sob o sistema cooperativo de produção, que contava com um papel fundamental em diversas etapas desse processo.

Com relação aos principais fatores associados ao sucesso dos negócios, segundo os entrevistados, a qualidade é o principal fator, seguido pela confiança de seus clientes. Para essa cooperativa, somente com produtos de qualidade é que a 
confiança de seus clientes é alcançada. Além disso, seus representantes destacam que se o produto não tiver qualidade, de nada adianta ter bom preço. É por isso que a cooperativa estabelece rígidos padrões de qualidade à produção de seus cooperados e com a mesma rigidez, promove o controle sistemático dessa qualidade exigida.

A participação da cooperativa em eventos técnicos como a Hortitec e outros eventos, já e um pratica histórica. Para ela, a participação nesse tipo de evento, promove a abertura de novos negócios ao mesmo tempo em que são eficientes para a divulgação da marca e novos produtos. Além disso, existe também a percepção de que, esse tipo de participação, mesmo que em menor intensidade, acaba por facilitar a aproximação com os clientes e o conhecimento de suas necessidades. Finalmente, os entrevistados comentaram que a participação em eventos traz a possibilidade de criar parcerias e cooperação através da maior aproximação com outras empresas e possibilita conhecer aquilo que está sendo oferecido pela concorrência.

Com relação à percepção sobre seu posicionamento no mercado, os entrevistados não identificam nenhum forte concorrente capaz de ameaçar o bom desempenho dos negócios da cooperativa. Mesmo tendo a certeza de que ainda depende de alguns clientes, a cooperativa se vê numa situação satisfatória em termos de posicionamento no mercado. A exceção dos poucos clientes que os entrevistados identificaram que a cooperativa ainda apresenta alguma dependência, ambos são enfáticos em apontar que sua estrutura the garante maio poder de barganha nas negociações com seus principais clientes.

Para a Cooperativa o acesso às fontes de financiamento é dificultado mais pelo excesso de burocracia do que pelas exigências mínimas de garantia. Os entrevistados demonstraram ter conhecimento das fontes públicas de financiamento, especialmente o BNDES (Banco Nacional de Desenvolvimento Econômico e Social), que disponibilizou acesso a linhas de credito recentemente. Com relação à percepção de como seus cooperados trabalham com essas linhas de credito, ambos entrevistados apontaram para o fato de que a grande maioria deles trabalha com as linhas públicas de crédito e conhecem as principais fontes de financiamento da produção, expansão e custeio de seus negócios. 


\subsubsection{Empresas Meio}

Fizeram parte deste estudo um total de doze empresas que atuam no sistema produtivo de flores e plantas ornamentais da localidade de Holambra. Essas empresas foram abordadas por ocasião da realização de duas edições seguidas da Expoflora: 2005 e 2006. As entrevistas foram realizadas individualmente, com diretores, gerentes ou consultores técnicos de negócios dessas empresas,no entanto, os relatos serão referidos pelos números das empresas.

\subsubsection{Bloco 1 - Caracterização Geral}

Esta seção apresenta a caracterização geral das empresas e respectivos respondentes das entrevistas realizadas com as "Empresas Meio", conforme sintetizado no Quadro 5.2.

Quadro 5.2. Caracterização geral das empresas participantes da pesquisa qualitativa

\begin{tabular}{|c|c|c|c|c|}
\hline EMPRESA & PORTE & RESPONDENTE & MUNICÍPIO & ATUAÇAO \\
\hline 1 & Médio & diretor & Holambra - SP & $\begin{array}{l}\text { substrato } \\
\text { agrícola }\end{array}$ \\
\hline 2 & Pequeno & sócio proprietário & Holambra- SP & irrigação \\
\hline 3 & Pequeno & sócio proprietário & Holambra- SP & $\begin{array}{l}\text { vasos e } \\
\text { plantas }\end{array}$ \\
\hline 4 & Grande & consultor técnico & Holambra- SP & $\begin{array}{l}\text { tecnologia } \\
\text { de } \\
\text { sementes }\end{array}$ \\
\hline 5 & Grande & gerente & São Paulo- SP & fertilizante \\
\hline 6 & Grande & gerente & Itápolis- SP & $\begin{array}{l}\text { produção de } \\
\text { telas e } \\
\text { sombrites }\end{array}$ \\
\hline 7 & Pequeno & diretor & Holambra- SP & $\begin{array}{l}\text { produtos } \\
\text { químicos } \\
\text { para estufas }\end{array}$ \\
\hline 8 & Pequeno & sócio proprietário & Holambra- SP & serviços \\
\hline 9 & Médio & diretor superintendente & Guarulhos- SP & $\begin{array}{l}\text { bandejas } \\
\text { plásticas }\end{array}$ \\
\hline 10 & Pequeno & técnico de vendas & Curitiba - PR & $\begin{array}{l}\text { tratamento } \\
\text { de ar }\end{array}$ \\
\hline 11 & Pequeno & diretor & Holambra- SP & serviços \\
\hline 12 & Pequeno & sócio proprietário & Holambra- SP & serviços \\
\hline
\end{tabular}

Fonte: o autor 
A maioria das empresas estudadas atua no segmento denominado no meio de "da porteira para dentro", ou seja, relacionados especificamente as atividades de produção agrícola e atuam especificamente na área de insumos (as empresas 1,3,4,5,6,7 e 9$)$.

Das empresas entrevistadas, cerca de $60 \%$ se encontra situada no município de Holambra, sendo que dessas, apenas uma é de grande porte e duas de médio porte. A empresa de grande porte, apesar de estar situada no município de Holambra, faz parte de uma holding com doze escritórios espalhados pelas Américas do Norte e do Sul, Europa, Ásia e Austrália. No Brasil sua única representação é em Holambra.

Das oito empresas sediadas em Holambra, apenas uma o fundador não tem ascendência holandesa. Nas demais, cinco foram constituídas após o fundador da empresa ter trabalhado como empregado em outra empresa que atuava no mesmo ramo ou em ramo similar aquele que estruturou seu negócio. No entanto, destas cinco empresas, apenas em um caso, julgou-se que a experiência adquirida nesse trabalho, que estava associado à tradição familiar, foi a principal fonte de conhecimento necessário para o desenvolvimento do próprio negócio. Para as demais empresas, a motivação e a experiência para a abertura do negócio próprio, vieram do estudo e da experiência profissional de forma ampla.

Dentre as empresas com sede fora de Holambra, em três o fundador tem ascendência brasileira, uma israelense e outra sueca.

\subsubsection{Bloco 2 - Cooperação e Parceria}

Apenas as empresas 1, 2, 11 e 12 (equivalente a $30 \%$ da amostra pesquisada) relataram desenvolver relações de parcerias com fornecedores ou clientes, sempre que possível. A empresa 10 relatou não efetuar esse tipo de atividade, justificando que até o momento não tinha sido necessário desenvolver esse tipo de ação e que isso não era usual em sua experiência de negócios. Apesar de haver a concordância entre todas as empresas entrevistadas frente à importância desse tipo de ação para o desempenho de seus negócios, algumas empresas alegaram não ter desenvolvido esse tipo de parceria, por condições estritamente 
pontuais, mas se mostram aptas para tal.

Dentre os motivos que levaram essas empresas a estabelecer esse tipo de ação, metade enfatizou o desenvolvimento ou melhoria de insumos, produtos ou processos de produção como principal motivo, cinco delas destacaram o compartilhamento de idéias e informações (técnicas, organizacionais, etc) de novidades tecnológicas.

A percepção geral dos entrevistados foi que a condição étnica não exerce nenhum tipo de favorecimento para que ações de cooperação sejam estabelecidas. Para essas empresas, o principal fator considerado quando se visa estabelecer esse tipo de ação, reside na consolidação das relações de comercio ao longo do tempo. Nesse aspecto, mostram haver importância da localidade, principalmente no tocante à identidade cultural presente e a proximidade entre os agentes, para a promoção desse tipo de ação.

Com relação ao desenvolvimento de parcerias e outras ações conjuntas com entidades governamentais de apoio e treinamento (como SEBRAE, SENAR, SENAI, etc.) a maioria destacou que não se vale desse tipo de parceria, devido à falta de um contato mais próximo com esses organismos. Já com relação às parcerias com as associações comerciais locais, apenas as empresas, 9, 11 e 12 manifestaram estabelecer algum tipo de ação conjunta com esse tipo de entidade, apesar de cinco das doze empresas pesquisadas, estarem associadas a esse tipo de organização.

Das doze empresas pesquisadas, nove estão associadas a algum tipo de atividade técnica de produção e dessas, apenas duas (as empresas 1 e 2) relataram que eventualmente estabelecem atividades conjuntas com as empresas de pesquisa ou de extensão agropecuária.

A participação das empresas em organizações associativas, tais como as associações patronais, associação setorial ou de produtores não se mostrou muito expressiva. Essa participação ficou restrita às empresas 1, 3, 4 e 6; todas elas mais diretamente relacionadas ao cultivo de plantas em ambiente protegido e apenas uma não sediada em Holambra. 


\subsubsection{Bloco 3 - Localidade}

As empresas estudadas apresentaram um padrão de resposta muito semelhante entre si. Foram unânimes em afirmar que a localidade de Holambra favorece o acesso aos centros consumidores, não só devido a proximidade dos grandes centros, mas também devido a estrutura de distribuição e logística presente nessa localidade, considerada uma das melhores do país.

Todos os entrevistados concordam que a localidade Holambra congrega bons (em alguns casos, os melhores) especialistas em comercialização e produção de flores do país, o que faz dela um centro de excelência na produção e comercialização de flores e plantas, reconhecida pelos profissionais dos agronegócios.

Além disso, são enfáticos em apontar que além da especialidade em flores e plantas ornamentais, a localidade congrega também especialistas em cultivo protegido e boa estrutura para esse tipo de cultivo. Isso faz com que, segundo opinião geral dessas empresas, a localidade também possa ser considerada como um pólo de excelência em cultivo protegido.

Apesar disso, a idéia de que esta localidade promove melhores condições para o desempenho dos negócios dessas empresas, se comparadas a outras localidades, não seguiu o mesmo comportamento. Apenas as empresas 2, 6 e 12 mostram-se efetivas em destacar positivamente esse beneficio. A melhor representatividade desses resultados pode ser consignada ao histórico e a área de atuação dessas empresas. As empresas 6 e 12 atuam em uma área muito relacionada às técnicas de cultivo protegido, mesmo sendo a empresa 12 uma prestadora de serviço. Já a empresa 2 foi fundada em Holambra e primeiramente se relacionava a projetos de climatização e irrigação em ambientes protegidos. Posteriormente, com o desenvolvimento dos negócios, passou a estender suas atividades para outras áreas, já em ambientes não climatizados.

A localidade foi vista pelas empresas aqui estudadas, como sendo um agente facilitador na aproximação entre os atores da cadeia, que tem em parte, a identidade cultural e étnica exercendo um forte papel agregador nesse sentido. Isso também, segundo as empresas estudadas, facilita a formação de parcerias entre os atores da cadeia. No entanto, a percepção de que essas parcerias favorecem de forma 
significativa o desenvolvimento de novos produtos e/ou novas técnicas de produção ficou restrita somente a três empresas. Dessas três empresas, apenas duas relataram a percepção de que essa aproximação pelo fator cultural aumenta a possibilidade de relacionamentos mais seguros nas atividades de negócios.

Nenhuma outra empresa, à exceção da empresa 5, que está situada em São Paulo-SP, mostrou-se enfática em apontar que a localidade promove maior disponibilidade de mão-de-obra. Das 12 empresas estudadas, cinco mostram-se reticentes quanto a este aspecto, enfatizando que tal disponibilidade pode mesmo ocorrer, no entanto em situações específicas, como épocas de maior atividade de produção e em áreas bem especificas. Dessas cinco empresas, somente uma não está localizada na cidade de Holambra.

Com relação ao papel desempenhado pelo poder local e por agentes governamentais de apoio, as empresas estudadas mostram-se no geral, muito descontentes com o governo local. Mesmo aquelas que não são sediadas na localidade de Holambra, cobraram uma postura mais efetiva dos poderes públicos municipal e estadual, no sentido de desenvolver ações mais especificas que efetivamente contribuam para o desenvolvimento dos negócios na localidade. $\mathrm{Na}$ amostra estudada não houve nenhuma empresa que manifestasse algum tipo de contentamento com o desempenho do poder público da localidade.

Também foi observado um comportamento comum entre as empresas pesquisadas, no sentido de identificarem que a localidade não repeli novos entrantes, seja por falta de identidade cultural ou mesmo pela retaliação dos atores relacionados aos negócios de flores e plantas da localidade. Isso, no entanto, não foi identificado com sendo uma desvantagem.

Os representantes das empresas não identificaram nenhum tipo de desvantagem proporcionada pela localidade Holambra. A possibilidade de elevação dos custos de infra-estrutura e mão-de-obra não foi considerada de maneira contundente por nenhuma empresa. Apenas três dessas empresas, manifestaram que identificam essa possibilidade no contexto futuro, mas que no momento ainda não se pode caracterizar isso como uma desvantagem significativa do local, mas que pode servir com um sinal de alerta. 


\subsubsection{Bloco 4 - Inovação e Informações}

A inovação presente nos negócios locais de flores e plantas ornamentais, segundo a percepção dos entrevistados do grupo das "Empresas Meio" pode estar associada basicamente às técnicas de cultivo e comercialização e ao desenvolvimento de máquinas e equipamentos capazes de agilizar o processo de produção. Para esses representantes, os processos de inovação são freqüentemente desenvolvidos sem a participação dos produtores rurais.

Com relação às fontes de informação capazes de contribuir para a geração de conhecimento e geração das competências locais, os fatores mais relacionados pelos entrevistados foram :

a) Conversas informais (nesse caso, incluindo produtores, lideranças locais ou mesmo empresários do mesmo ramo de atividades ou de outros ramos relacionados aos agronegócios de flores e plantas).

b) Vendedores.

c) Participação em feiras e eventos similares (como expositor ou visitantes).

d) Clientes.

e) Publicações especializadas.

f) Visitas a empresas e/ou propriedades de fora da região.

\subsubsection{Bloco 5 - Gestão e Estratégias}

Com relação à percepção sobre os fatores principais para o sucesso de seus negócios, todas as empresas deste grupo consideraram a qualidade e a confiança de seus clientes como os dois principais fatores de sucesso para os seus respectivos negócios na localidade. Apenas para as empresas 1, 4, 7, 8 e 9, a entrega rápida e pontual, também apresenta o mesmo nível de importância, mas isso não encontrou respaldo no restante das empresas. Observa-se que as empresas foram unânimes também em destacar a oferta de produtos inovadores com maior grau de importância no sucesso de seus negócios. Congruente com esta 
percepção é o fato de todas empresas pesquisadas não considerarem preço, fator importante para os sucessos de seus negócios na localidade. As empresas 5, 7, 8, 9 e 10 foram enfáticas em afirmar que esse fator não é decisivo para a condução de seus negócios na localidade. Já a empresas 1, 2 e 4 apesar de manifestarem concordância de que o preço não seja um fator decisivo, argumentam que ele deva ser considerado na condução de seus negócios, ou seja, não é ganhador de pedido mas é qualificador.

Com relação ao conhecimento específico do mercado de flores e plantas ornamentais, as empresas estudadas não demonstraram um conhecimento muito específico desse mercado, dado que nenhuma atua exclusivamente neste negócio. No entanto, em termos gerais, foram capazes de identificar possibilidades de crescimento, principalmente no que se refere ao mercado interno. Apenas uma das empresas estudadas não foi capaz de relatar se apresentava condições de atender à um aumento na demanda de seus negócios. As demais, todas se mostraram capazes de atender a esse aumento, sendo que em sete das doze empresas pesquisadas, esse aumento poderia chegar a $100 \%$ de sua demanda atual e somente duas conseguiriam atender a um crescimento de demanda inferior a $25 \%$ capacidade atual. Isso mostra que há na localidade capacidade ociosa, com margem para que as empresas absorvam o crescimento provocado por um incremento dos negócios locais. Nenhuma das empresas pesquisadas foi capaz de estimar uma faixa de crescimento do mercado.

As estratégias de venda das empresas estudadas estão concentradas na venda direta ao consumidor final. A maioria vende entre $80 \%$ e $100 \%$ de seus produtos para o consumidor final, apenas as empresas 3 e 6 não acessam diretamente os consumidores finais de seus produtos, enquanto a empresa 4 chega a trabalhar com até $2 \%$ de venda direta ao consumidor. Três empresas 3,4 e 10 trabalham com uma margem entre $70 \%$ e $100 \%$ de vendas para o mercado atacadista e outras duas com o mercado varejista (a empresa $6 \mathrm{com} 100 \%$ e a empresa 9 com 10\%). Esses dados são coerentemente relacionados ao perfil das empresas trabalhadas, denominadas neste estudo de empresas meio e mostram que a grande maioria delas tem possibilidade de acesso direto ao produtor rural e isso se mostra coerente com a percepção do grupo de que a qualidade e a confiança percebida pelo cliente são os dois principais fatores de sucesso de seus 
negócios. Apenas duas empresas (empresas 2 e 8) participam de algum tipo de consórcio entre empresas para acesso ao mercado consumidor.

Existe dependência com relação à fornecedores específicos, relatada por todas as empresas entrevistadas. Para cinco delas, relacionadas à produção de insumos, essa dependência está fundamentalmente associada ao aporte tecnológico ou na dependência de matéria prima específica para sua fabricação de seus produtos (substrato agrícola, irrigação, vasos e plantas, tecnologia de sementes, fertilizante, produção de telas "sombrites"). Para as demais empresas, essa dependência, apesar de identificada não chega a atingir níveis que comprometam a continuidade de seus negócios.

Ainda com relação às estratégias de venda utilizadas por essas empresas, foi possível também observar, à exceção da empresa 2, o mesmo comportamento para todas as empresas, no que se refere à marca de seus produtos, que são sempre comercializados com marca própria e nunca com a marca da localidade ou com outro tipo de marca. A empresa 2 relatou que seus produtos não são comercializados com sua própria marca, por se tratar de uma empresa que presta serviços na área de irrigação. Além disso, atua na área de elaboração de projetos (que comportaria sua marca) e também atua como representante de empresas internacionais de peças e equipamentos de irrigação.

Com relação à participação em eventos técnicos, as empresas entrevistadas mostraram ter um histórico freqüente de participação nesse tipo de evento. Participam da Hortitec como expositores e de outros eventos similares. Além disso, freqüentemente enviam seus representantes para outros eventos, incluindo no caso de algumas empresas (empresas 2, 4 e 7) eventos de caráter internacional. Para todas as empresas pesquisadas, houve a percepção unânime de que a participação como expositores nestes tipos de evento facilita a difusão de sua marca e/ou produto. Também de forma unânime, essas empresas relataram que a aproximação com os clientes e as visitas aos seus "stands" contribuem (mesmo que de forma não decisiva) para uma maior aproximação e melhor conhecimento das necessidades de seus clientes, além de permitir um melhor conhecimento do que está sendo oferecido pela concorrência.

A realização dessas feiras, exposições técnicas e eventos similares geralmente é estruturada com base na divisão dos setores de visita com base na área de atuação das empresas. Isso acaba por aproximar num único espaço físico e 
às vezes até em locais muito próximos, empresas concorrentes, explicando em parte, a vantagem relatada pelas empresas estudadas, de que assim é possível observar melhor o que está sendo oferecido no mercado em que atuam.

Apenas duas empresas (empresas 9 e 10) relataram que além disso, a participação nesses tipos de eventos também proporciona uma maior possibilidade na criação de parcerias com outras empresas. No entanto, nenhuma dessas duas empresas destacou ter estabelecido algum tipo de parceria relevante, em função da participação nesse tipo de evento.

Destaca-se que para nenhuma das empresas entrevistadas, a participação nesse tipo de evento tem como principal objetivo, a realização de novos negócios. Apesar de considerarem que tais participações possam contribuir para isso, nenhuma delas apresenta a percepção de que essa contribuição seja concretizada de forma expressiva.

A visão das empresas estudadas quanto ao papel fundamental do cooperativismo e associativismo na construção das vantagens competitivas da localidade mostrou que apesar da percepção da importância do papel das cooperativas (sobretudo o Veiling e a anteriormente da Cooperativa Agropecuária de Holambra) ao longo da história na localidade, não são capazes de identificar, especificamente, que a estrutura cooperativista tem ou não papel relevante nesse processo construtivo.

No que concerne às percepções relativas ao acesso aos mecanismos de financiamento dos negócios, as empresas estudadas se mostraram bastante descontentes com o cenário atual, não só aquelas situadas na localidade como também as demais, manifestaram essa percepção. Dentre os motivos que sustentam essa insatisfação, dois se destacaram: a dificuldade de acesso aos agentes e o excesso de burocracia. O excesso de burocracia foi enfatizado por todas as empresas estudadas, enquanto que 0 acesso aos agentes de financiamento foi enfaticamente manifestado pelas empresas de pequeno porte (2, 3,7 e 11) e todas elas sediadas no município de Holambra. Associado a dificuldade de acesso aos agentes de financiamento, cinco empresas (das quais apenas uma de médio porte e as demais de pequeno porte) identificaram que o desconhecimento dos agentes e das linhas de financiamento, associados à falta de divulgação, aumenta a dificuldade ao acesso aos agentes de financiamento. 
As dificuldades relatadas para o acesso aos agentes de financiamento são refletidas nas fontes de financiamento que essas empresas se utilizam para aumentar sua capacidade produtiva, cujo potencial de crescimento já foi abordado anteriormente. Todas as empresas consultadas mostraram que o próprio capital é o principal recurso utilizado para a expansão de sua capacidade produtiva. Apenas as empresas 5 e 9, que são respectivamente de médio e grande porte, sediadas fora do município de Holambra, manifestaram recorrer ao bancos públicos para esse tipo de financiamento.

\section{2. ESTUDO DE CAMPO NA LOCALIDADE DE MOGI DAS CRUZES}

Os resultados aqui descritos representam a amostragem de um total de 16 representantes dos diversos atores da cadeia de flores e plantas ornamentais presentes na localidade de Mogi das Cruzes.

O Quadro 5.3 resume a composição da amostra estudada, em função do número de grupos considerados e o perfil de seus representantes entrevistados, tendo-se como base os roteiros elaborados, conforme apresentado no Capítulo 3.

Quadro 5.3. Composição da Amostra: Mogi das Cruzes

\begin{tabular}{lcl}
\hline Tipo de organização & $\begin{array}{l}\text { Quantidade } \\
\text { de } \\
\text { entrevistas }\end{array}$ & Perfil do Entrevistados \\
\hline Associações de Produtores Rurais & 15 & $\begin{array}{l}\text { 13 Produtores, } 1 \\
\text { coordenador técnico de } \\
\text { área e uma gerente } \\
\text { Coordenador de Projeto }\end{array}$ \\
Entidades de apoio - Sindicatos & 1 & \\
\hline TOTAL & 16 & \\
\hline
\end{tabular}

Fonte: o autor

Pode-se observar pelo Quadro 5.3 que a pesquisa de campo na localidade de Mogi das Cruzes foi realizada apenas com representantes das associações de produtores e com as entidades de apoio. Se comparado com os grupos analisados na localidade de Holambra (ver Quadro 5.1), dois grupos não foram contemplados, quais sejam: Cooperativas e Empresas Meio. 
No que concerne ao grupo Cooperativas, embora a localidade de Mogi das Cruzes (descrita no item 4.4) apresente uma estrutura muito marcada pela presença da colônia japonesa organizada na cooperativa SP Flores e na Associação dos Floricultores da Região da Via Dutra (AFLORD), vale destacar que a cooperativa originou-se nas dependências da Aflord, o que faz com que o quadro de associados da SP-Flores e da AFLORD apresente grande sobreposição, ou seja, vários produtores são associados de ambas. A criação da SP Flores ocorreu para viabilizar a atuação em atividades comerciais, o que não é permitido na AFLORD. Portanto, como os atores são os mesmos, em ambas entidades, as entrevistas foram feitas apenas na AFLORD.

Já o grupo "Empresas Meio', não foi considerado no estudo de campo nesta localidade, uma vez que não existem empresas exclusivamente relacionadas à floricultura nesta localidade, sendo a demanda atendida prioritariamente pelas revendas de produtos agropecuários em geral.

\subsubsection{Associações de Produtores Rurais}

Conforme descrita anteriormente, a localidade de Mogi das Cruzes conta com apenas uma associação de produtores que atua nas atividades produtivas de flores e plantas ornamentais, a AFLORD - Associação dos Floricultores da Região da Via Dutra.

Uma primeira entrevista foi efetuada por ocasião de uma reunião do Grupo Técnico da AFLORD (GTA), que contou com a presença do coordenador do grupo e quinze associados. Nesta dinâmica de grupo, foram gravados os comentários, que são apresentados pela denominação de GT, pois não foi possível identificar as observações individualmente. Em seguida foi realizada uma entrevista com a gerente da área de fitossanidade dessa Associação, que será denominada gerente. Os resultados relatados a seguir são frutos da compilação desses dois momentos de entrevistas. 


\subsubsection{Bloco 1 - Caracterização Geral}

Essa associação conta hoje com 86 associados, localizados nos municípios de Guarulhos, Mogi das Cruzes, Itaquaquecetuba, Santa Isabel, Guararema, Jacareí e São José dos Campos e Taubaté

A preocupação com a produção de flores e folhagens diferenciadas pela qualidade foi um dos motivos que incentivaram sua formação, em 1981. A AFLORD hoje focaliza suas atividades na promoção da troca de informações sobre técnicas de cultivo, comercialização, padronização dos produtos oferecidos e prestação de serviços de assistência técnica de qualidade para seus associados. Esta associação não atua nas atividades comerciais, não interfere nas decisões sobre espécies a serem cultivadas e nem na quantidade a ser produzida.

Como forma de divulgar os produtos de seus associados, há quinze anos essa associação promove um importante evento regional de floricultura denominado "Expoaflord", também conhecida como "a festa das flores de Arujá".Trata-se de um evento de caráter comercial, no qual são fornecidas orientações por engenheiros agrônomos e técnicos agrícolas relacionados à própria Associação, sobre como garantir maior durabilidade e controle fitossanitário dos produtos adquiridos. Além desse forte caráter comercial e promocional, há também uma vertente para a promoção da cultura e culinária japonesa local.

A área média das propriedades de seus associados é de aproximadamente 10 hectares, com cerca de $80 \%$ de área produtiva. O nível tecnológico desses associados é muito heterogêneo, alcançando produtores que já contam com estruturas semi computadorizadas ou laboratórios de micropropagação de orquídeas. A AFLORD também tem um laboratório desse tipo.

A Associação demonstra também intensa preocupação com a capacitação técnica de seus associados, como forma de garantir a qualidade dos produtos ofertados. Além do citado laboratório de propagação de orquídeas, a Associação conta com um corpo técnico específico nas áreas de fitossanidade, nutrição de plantas e produção de mudas. Atualmente, a AFLORD busca desenvolver outras áreas, especialmente no que se refere às atividades "da porteira para fora", mantendo grupo de estudos e debates, no âmbito do GTA. Esse grupo, atualmente 
tem desenvolvido esforços no sentido de estudar melhores formas de comercialização e para o desenvolvimento de novos mercados.

Além da expressiva vertente tecnológica, a AFLORD também fornece aos seus associados, informações freqüentes sobre linhas de financiamento disponíveis e cursos de capacitação gerencial.

Esta associação não apresenta destacada atuação política, pois não desenvolve atividades freqüentes no sentido de ajudar no estabelecimento de políticas públicas para o setor. Os entrevistados do GTA julgam que este não é um papel específico da entidade e que por isso, apesar de poder discutir temas desta natureza internamente entre seus associados, acredita que essa contribuição seja maior, através da participação de seus associados, na condição de produtores, em entidades específicas para esse fim.

A percepção predominante no GTA é que a Associação se considera bem atuante no sentido de promover o desenvolvimento dos agronegócios de flores de seus associados, não só através do oferecimento de assistência técnica de qualidade, como também incentivando a participação de seus associados em feiras e eventos relacionados aos seus negócios específicos.

\subsubsection{Bloco 2 - Cooperação e Parceria}

A AFLORD desenvolve atividades em parceria para fomento tecnológico, com institutos de pesquisa (Instituto Biológico e a Agencia Paulista de Tecnologia dos Agronegócios), pesquisadores de empresas do setor de agroquímicos, sementes, agricultura orgânica; além de entidades como SENAR e SEBRAE. A entidade não desenvolve parcerias com a CATI, pois segundo percepção dos entrevistados, falta uma estrutura adequada para este órgão de Governo. Além disso, desenvolve atividades de pesquisa em parceria com a Universidade de Mogi das Cruzes e também com a FAPESP (Fundação de Amparo à Pesquisa do estado de São Paulo).

Segundo os entrevistados do GTA, os motivos específicos que incentivaram a realização dessas parcerias entre os produtores podem ser observados em quase todos os itens relacionados no roteiro utilizado nesta pesquisa, quais sejam: participação em feiras e eventos, assessoria jurídica, assessoria administrativa, 
informações de mercado, boletins de informação, novas variedades, capacitação de mão-de-obra, cursos e seminários para o produtor, acesso e conhecimento de novas tecnologias e linhas de crédito.

Ainda segundo o GTA, a intensidade e a motivação para parceria entre produtores é muito dependente do momento em que os negócios estão vivendo e especificamente pode variar em função variedades de espécies produzida por seus associados.

Com relação a influencia étnica sobre o estabelecimento de ações de parcerias na localidade de Mogi das Cruzes, não foi possível caracterizar esse fator como influente ou não nas parcerias estabelecidas por seus associados, uma vez que não há nesta entidade produtores que tenham outra ascendência, que não a oriental (japonesa especificamente). Apesar disso, segundo foi bem especificado pelo GTA e pela gerente, é comum a ocorrência de situações em que os produtores estejam muito mais próximos e envolvidos quando tratam de questões culturais, como festas típicas ou a promoção de eventos relativos à responsabilidade social da comunidade, do que quando estão envolvidos em atividades de negócios.

A gerente da AFLORD não pode manifestar sua percepção quanto às ações de parceria desenvolvidas por seus associados, alegando que até por característica étnica/cultural, são todos muito discretos e reservados e relatam pouco esse tipo de ação nas oportunidades em que estão reunidos. Por esse motivo, não chega a considerar como sendo freqüente esse tipo de ação entre seus associados, quando voltadas às suas atividades de negócios. Nesse sentido, ela manifesta com muita convicção que a associação não estreita os laços de relacionamento e confiança entre seus associados, mas por outro lado, enfatiza que esse tipo de organização de produtores é fundamental para a construção das bases competitivas da localidade.

\subsubsection{Bloco 3 - Localidade}

Segundo a percepção dos entrevistados, a localidade de Mogi das Cruzes, considerada neste estudo é intensamente reconhecida pelos profissionais dos agronegócios nacionais, pela produção de flores, horticultura e fruticultura. 
Historicamente, julgam que essas atividades já se consolidaram como as importantes na região.

Quanto ao papel desenvolvido pela governo local para a construção das bases competitivas dos agronegócios de flores na região, a percepção predominante entre os entrevistados da AFLORD é que não nenhum tipo de atividade mais significativa, que possa fazer diferença nesse sentido.

O GTA identifica duas vantagens significativas da localidade: uma relacionada à promoção de um melhor acesso à matéria-prima, infra-estrutura e assistência técnica, e outra relacionada as facilidades logísticas para a comercialização e distribuição dos produtos de seus associados. No entanto, adverte o GTA, isto ainda não significa que na região esteja concentrada a melhor infra-estrutura para a comercialização de flores e plantas no país.

Para o GTA, não é possível dissociar os negócios de seus associados da localidade, uma vez que todos apresentam forte identidade histórica e cultural com a região e que por esse motivo, fica muito difícil avaliar se o desempenho de seus negócios seria superiores aos que poderiam ser observados se eles estivessem localizados em outra região.

Não obstante, os entrevistados da AFLORD também manifestaram a percepção de que, mesmo não tendo papel decisivo, a localidade favorece o acesso ao mercado consumidor, à maior disponibilidade mão-de-obra, a treinamento e na a aproximação com outros produtores. Com isso promove desenvolvimento de novos produtos e/ou novas técnicas de produção.

Já com relação à possibilidade de ocorrência de desvantagens competitivas advindas da concentração de agronegócios na região, tais como, pressionar os custos de infra-estrutura e mão-de-obra para cima ou de promover um maior desgaste da infra-estrutura local, para o GTA ainda não há indícios de ocorrência. A gerente argumenta que não existe ainda na região uma concentração de mão-deobra tão intensa e nem uma infra-estrutura tão intensamente utilizada que promova qualquer risco dessa natureza, por parte dos produtores de flores e plantas ornamentais.

No que tange aos aspectos da influencia da localidade frente às relações e ações conjuntas de cooperação entre os produtores, os entrevistados não puderam caracterizar qualquer tipo de efeito (positivo ou negativo) da localidade sobre esses fatores. 


\subsubsection{Bloco 4 - Inovação e Informações}

Os entrevistados da AFLROD mostram uma percepção unânime de que a inovação presente nos negócios locais de flores e plantas pode estar associada ao desenvolvimento ou adaptação de novas variedades, técnicas de cultivo e comercialização, desenvolvimento de máquinas e equipamentos capazes de agilizar o processo de produção, nas embalagens para o acondicionamento das flores e plantas e o desenvolvimento de marcas próprias.

Apesar do fato de que durante o processo de entrevistas, o sistema de leilão (clok) estava em processo de implantação na cooperativa SP-FLORES, da qual fazem parte todos os entrevistados do GTA, esses não consideraram isto como uma inovação, pois uma forma similar de leilão já é utilizado há tempos no Veiling em Holanda, desde a década de 1990.

Segundo a visão da gerente da AFLORD, as inovações no negócio de flores e plantas ornamentais, assim como na maioria das outras atividades agropecuárias, são desenvolvidas muito mais pelas indústrias de insumos e maquinários do que nas propriedades rurais. Para ela, o envolvimento dos produtores é muito raro nesse tipo de processo, que muitas vezes até não está devidamente capacitado ou aparelhado, para utilizar grande parte das inovações geradas.

Com relação à identificação das principais fontes de informação capazes de contribuir para o desenvolvimento dos negócios de seus associados, somente uma, dentre àquelas identificadas no roteiro de pesquisa, não foi considerada relevante pelos entrevistados: a assistência técnica governamental. Vários produtores do GTA justificaram a exclusão devido à precariedade do aparelho público, conforme já haviam se manifestado com relação à distância que os técnicos da CATI se encontram da maioria dos produtores da localidade.

\subsubsection{Bloco 5 - Gestão e Estratégias}

Conforme já relatado anteriormente, a AFLORD, embora não desempenhe atividades comerciais, tem incentivado o GTA a trabalhar nesses últimos anos, com foco nas discussões de questões comerciais e de abertura de novos mercados. Para 
isso, tem reservado parte dos encontros deste grupo para debater essas questões e avaliar possíveis ações futuras, que inclusive passam pela definição do papel da AFLORD e da SPFlores nesses assuntos. Ficou evidenciado que o foco neste momento é o mercado interno e mais especificamente, um nicho de mercado que se mostra capaz de absorver produtos com maior qualidade, sem levar em conta o fator preço. Nesse sentido, a gerente é enfática ao salientar que o preço não está dentre os principais fatores determinantes para o sucesso de seus negócios. Os entrevistados foram unânimes em salientar que qualidade e a confiança dos clientes são os principais fatores, seguidos pela entrega pontual e pelo oferecimento de produtos inovadores

Apesar de identificarem um potencial de crescimento no mercado em que atuam seus associados, a gerente da AFLORD não foi capaz de identificar qualquer possibilidade de aumento maior do que $25 \%$ na produção atual que esses oferecem. A percepção geral do GTA é que o mercado de flores e plantas ornamentais ainda tem espaço para crescimentos, principalmente no âmbito nacional.

Segundo os entrevistados, o mercado internacional fica mais restrito para determinados tipos de cultivo, especialmente para as plantas em vaso, o principal produto da maioria de seus associados. Existem barreiras fitossanitárias muito intensas que praticamente impedem o acesso a esses mercados e para produção de plantas de corte. Além disso, as recompensas geradas pelos mercados nacionais ainda são mais atrativas quando consideradas todas as normas e exigências do mercado internacional.

No que se refere à percepção dos principais clientes de seus associados, - GTA considerou que uma qualificação exata não seria possível, dada a heterogeneidade no perfil dos clientes de seus noventa associados. Segundo a gerente, em sua grande maioria, os associados agora estão utilizando a cooperativa (SP-Flores) e o clientes são atacadistas e profissionais e/ou empresas relacionados as áreas de decoração e paisagismo.

Já com relação à concorrência, para o GTA não existe um local específico onde possam estar concentrados os principais concorrentes de seus produtores. Segundo a gerente, existe uma definição clara dos nichos de mercado para cada região produtora e isso dificulta a identificação dos principais concorrentes. Segundo dizeres da própria gerente: 
"Isso não significa dizer que não existam concorrentes. Eles existem, mas isso vai depender da espécie cultivada. Com relação à orquídea Dendrobium ${ }^{8}$, por exemplo, dificilmente haverá um produtor que consiga concorrer com os associados da AFLOR, dada a condições específicas de clima e altitude, que esse possuem em suas propriedades. Com relação a outras espécies, existe a possibilidade de se encontrar concorrentes em outros locais como Holambra ou Atibaia, mas são casos muito específicos, pois o mercado em que a maioria desses produtores atua não os obriga a ter os padrões de qualidade que apresentam seus associados."

Com relação às estratégias financeiras, os entrevistados foram unânimes em destacar que entre seus associados existe um bom padrão de conhecimento das fontes para financiamento da produção e de custeio. Os investimentos são feitos com os próprios recursos dos produtores ou através da captação em agentes públicos prioritariamente.

\subsubsection{Entidades de Apoio}

O roteiro de entrevista para Entidade de Apoio foi aplicado a um Engenheiro Agrônomo vinculado ao Sindicato Rural de Mogi das Cruzes e ao SEBRAE, coordenador do projeto "Circuito das Flores", cujo objetivo é fomentar o agro-turismo na região e ao mesmo tempo promover a floricultura local

Esse projeto é desenvolvido no âmbito de um programa do SEBRAE, denominado "Cadeias Produtivas Agroindustriais", iniciado em 2002 e também associado a um outro programa desse mesmo órgão, denominado "SAI - Sistema

\footnotetext{
${ }^{8}$ A orquídea Dendrobium nobile é natural da parte baixa do Himalaia e regiões serranas do Sri Lanka, estando adaptada às condições brasileiras.(maiores informações em CAMPOS, D. M. Orquídeas: manual prático de cultura. 2. ed. Rio de Janeiro: Expressão e Cultura, 1998. p.140-141 ou em HUBER, G. Onde se desenvolvem as orquídeas. 5. ed. Rio de Janeiro: Expressão e Cultura, 1994. p.14-16)
} 
Agroindustrial Integrado". Participam ainda do projeto, o Sindicato Rural de Mogi das Cruzes, a SP Flores e a AFLORD.

\subsubsection{Bloco 1 - Caracterização Geral}

A capacitação profissional de empregados e o desenvolvimento de estudos técnicos de mercado com relação às atividades de produção de flores e plantas ornamentais, são as duas principais atividades desenvolvidas pelo SEBRAE e pelo Sindicato rural de Mogi das Cruzes. Essas atividades são concentradas na região de Mogi das Cruzes, não contemplando todos os municípios da região da Rodovia Presidente Dutra.

No desenvolvimento dessas atividades, o SEBRAE não estabelece contato freqüente com técnicos da CATI, pesquisadores de institutos como IAC e EMBRAPA, pois não desenvolve pesquisas nas áreas técnicas. No entanto, segundo o entrevistado, o propósito das ações que buscam desenvolver na localidade leva a que a entidade incentive de maneira sistemática ações de parceria entre os atores da cadeia e que contribuam de maneira significativa na construção de políticas públicas para o setor.

\subsubsection{Bloco 2 - Cooperação e Parceria}

O SEBRAE estabelece um grande número de ações conjuntas para o desenvolvimento de suas ações na região de Mogi das Cruzes, abrangida pelo escritório. No que se refere às atividades especificas ligadas ao sistema produtivo de flores e plantas ornamentais, esse tipo de ação fica concentrada para o desenvolvimento do projeto "Circuito das Flores".

No que se refere à percepção da freqüência de parcerias que os agentes da cadeia realizam, o entrevistado identificou parcerias do SEBRAE apenas entre órgãos similares tais como SENAR e o próprio Sindicato Rural, mesmo não apresentando uma alta freqüência. No entanto, as parcerias entre produtores rurais, 
seus clientes, entidades de pesquisa e extensão rurais, o engenheiro considerou baixa.

Com relação às parcerias desenvolvidas pelos componentes do sistema agroindustrial de flores, a percepção do entrevistado apontou os seguintes motivos que levam a busca de parcerias:

a) Participação conjunta em feiras (nacionais e/ou internacionais), exposições, e eventos similares.

b) Para o estabelecimento de compras conjuntas de insumos e equipamentos;

c) Para o compartilhamento de idéias e informações (técnicas, organizacionais, etc).

d) Para acesso a novidades tecnológicas, desenvolvimento ou melhoria de insumos, produtos ou processos.

e) Principalmente para a capacitação e treinamento de pessoal, através de atividades como cursos abertos ou eventos do tipo "dia de campo".

O entrevistado enfatizou sua percepção de que o convívio com outros produtores e com a comunidade étnica, para ambas, mostra-se muito relevantes para o estabelecimento de atividades de parceria. A consolidação das relações comerciais com o tempo foi um outro fator identificado no processo de estabelecimento dessas ações, porém com um grau menor de significância, segundo o entrevistado. Interessante observar que a atuação de entidades como o SEBRAE, SENAR e Sindicato Rural, não foram consideradas significativas para a consolidação dessas parcerias.

\subsubsection{Bloco 3 - Localidade}

Para o entrevistado a produção de Flores e os agronegócios em geral, são as duas principais características relacionadas à localidade. No entanto, mesmo considerando que nela existam profissionais de destaque, no que se refere à produção de flores e plantas ornamentais, a região de Holambra ainda é a mais importante região relacionada aos agronegócios de flores e plantas do país. 
Reforçando sua visão, destaca o fato de que naquela região deve se considerar não só a estrutura de comercialização instalada, mas o fato de que vários produtores (inclusive da região de Mogi das Cruzes) estão migrando para lá. Isso no entanto, não significa que Holambra apresente as melhores condições para o desenvolvimento desse tipo de negócios. Essas condições, para o entrevistado, são em primeiro lugar, determinadas pela espécie que busca cultivar. Relata ainda que juntas, as regiões de Holambra, Atibaia e Mogi das Cruzes são as mais importantes do Estado, sem qualquer possibilidade de questionamento.

Apesar de apresentar a vantagem de estar localizada próxima às duas principais rodovias Federais do Estado de São Paulo, interligando os principais centros consumidores do sul e sudeste, o entrevistado não destacou nenhuma percepção efetiva sobre as vantagens associadas à localidade. Isso em parte explica a necessidade do projeto sob sua coordenação na região.

No entanto, uma possível vantagem identificada, está relacionada a percepção de que a entrada de novos atores que não tenham nenhum vínculo com a localidade é em parte, dificultada devido à dificuldade de aceitação dos mesmos por parte do grupo de atores local. No entanto, esse não chega a ser um fator que represente uma barreira de entrada significante.

Com relação as desvantagem que podem ser associadas à localidade, também nenhum fator mais incisivo foi identificado. Apenas o possível aumento das rivalidades e conflitos entre os concorrentes e a possibilidade de elevação dos os custos com infra-estrutura para cima, foram relatados, no entanto, sem também contar com nenhuma ênfase maior.

No que se refere à competência para cultivos em ambiente protegido, mesmo sendo a localidade, a mais importante produtora de hortaliças do Estado de São Paulo, as condições locais não permitem que se considere a região como referencia, mas como uma importante região para esse tipo de cultivo. Para o entrevistado e também representante do SEBRAE, a geração de conhecimento referente à tecnologia de produção e comercialização de flores e plantas no Brasil está prioritariamente concentrada no município de Holambra e Região e nas empresas privadas de insumos e maquinários. 


\subsubsection{Bloco 4 - Inovação e Informações}

O representante do SEBRAE e do Sindicato Rural destaca que a geração de conhecimento, principalmente relacionada à tecnologia de produção e comercialização é um dos principais fatores de sucesso para a os agronegócios de flores e plantas ornamentais e por esse motivo, a inovação de produtos e ou processos de comercialização (principalmente) podem ser alvo de ações pontuais da entidade.

Nesse sentido, identificou as seguintes fontes de informação para a geração do conhecimento:

a) Conversas informais; entidades de apoio (Sebrae, Senar, centros de tecnologia, etc) e associações de produtores.

b) Feiras e eventos similares.

c) Visitas a outras empresas e/ou propriedades da região.

d) Clientes.

e) Vendedores e consultores especializados de outras regiões

f) Visitas a empresas e/ou propriedades de fora da região.

g) Troca de informações com outros produtores.

h) Assistência técnica privada.

No que concerne identificação dos fatores que podem ser relacionados a inovação no contexto dos agronegócios de flores e plantas ornamentais, o entrevistado identificou: variedades, cultivares, etc; técnicas de cultivo; técnicas de armazenagem; adaptação de espécies às condições locais de cultivo; selos de origem e/ou qualidade; técnicas de adubação e controle fitossanitário; comercialização; processos administrativos da propriedade rural e o desenvolvimento de uma marca própria local.

\subsubsection{Bloco 5 - Gestão e Estratégias}

Apesar de considerar que o mercado nacional de flores e plantas seja uma oportunidade crescente de negócio para os produtores de flores de determinadas espécies. Para o representante do SEBRAE e do Sindicato Rural, o mercado 
internacional está mais promissor, principalmente para as espécies de flores de corte, onde as exigências fitossanitárias são mais acessíveis às condições dos produtores da localidade de Mogi das Cruzes.

Com relação à presença de um agente coordenador da cadeia, efetuada por algum tipo de organização de produtores rurais, o entrevistado não relaciona nenhum tipo de relevância como fator essencial para a promoção dos agronegócios de flores e plantas. Já com relação à concentração geográfica e setorial de empresas, é tida como importante, porém não o principal fator para esse sucesso. Fatores como comercialização e aptidão técnica foram destacados como sendo de extrema importância nesse sentido.

A falta de um padrão adotado por todos os produtores de plantas e flores apesar de se tornar um problema nesse tipo de negócio, não chega a comprometêlo significativamente, assim como também não comprometem as formas e fontes de disponibilização de recursos financeiros para custeio e investimento.

\subsection{ENTREVISTA COM ATORES DE FORA DAS LOCALIDADES ESTUDADAS}

Os resultados aqui descritos representam a síntese das entrevistas realizadas na Câmara Setorial de Flores e Plantas Ornamentais e na Companhia de Entrepostos e Armazéns Gerais de São Paulo (CEAGESP). O Quadro 5.4 resume a composição da amostra estudada, em função do numero de grupos considerados e o perfil de seus representantes entrevistados, tendo-se como base os roteiros elaborados, conforme apresentado no Capítulo 3.

Quadro 5.4 Composição da amostra dos atores externos entrevistados

\begin{tabular}{lcll}
\hline Tipo de organização & Quantidade & Perfil do(s) Entrevistado(s) \\
\hline Câmara Setorial de Flores e Plantas & 1 & Presidente \\
Ornamentais & & 1 & Gerente \\
CEAGESP & 2 & \\
\hline TOTAL & &
\end{tabular}

Fonte: o autor 


\subsubsection{Câmara Setorial de Flores e Plantas Ornamentais}

Instalada em dezembro de 2003, a Câmara Setorial de Flores e Plantas Ornamentais está vinculada ao Ministério da Agricultura, Pecuária e Abastecimento tem como principal objetivo propor, apoiar e acompanhar ações para o desenvolvimento das atividades do desse setor produtivo.

A necessidade de implementação de ações estratégicas voltadas para a promoção dos negócios de flores e plantas ornamentais em nível nacional é hoje uma das prioridades do setor e fez parte das ações de discussão desta Câmara, além de constar na lista de ações estratégicas para o setor, programadas pelo IBRAFLOR. No entanto, o estudo específico da cadeia de flores e plantas ornamentais sob o enfoque das concentrações geográficas de empresas não está sendo discutido como ação específica.

Para o presidente da Câmara Setorial, a experiência de Holambra mostra que a concentração geográfica de empresas traz vantagens ao sistema produtivo como um todo. A presença de técnicos especializados tanto na área de cultivo e produção de flores, como na área de comercialização é uma das principais vantagens destacadas. Isso acaba criando situações em que, segundo o presidente, pesquisadores de várias instituições vêm até o município na busca de solucionar alguns problemas de pesquisa.

Para o entrevistado, nos demais centros produtores de flores em São Paulo e em outros Estados do Brasil, existem também muitos profissionais especializados na área, mas em Holambra, a presença desse tipo de profissional é marcante, principalmente no que diz respeito ao nível dos produtores sediados na localidade, que segundo ele, é extremamente elevado.

Com relação à formação de conhecimento na localidade, o representante da câmara Setorial de Flores e Plantas ornamentais foi enfático ao relatar que sem dúvida, a contribuição da localidade para a construção das competências específicas para o cultivo, produção e comercialização de flores é significativamente importante. Destaca que, se a geração de conhecimento e aprendizado não fosse significativo na localidade de Holambra, não haveria a quantidade expressiva de exfuncionários que através do conhecimento adquirido nas propriedades onde trabalharam, acabaram montando seu próprio negócio. Isso pode ser observado na 
origem de uma das pequenas cooperativas de comercialização da localidade, que se originou de um grupo de cooperados de uma outra cooperativa de comercialização, que buscava incorporar alternativas para comercio e distribuição de seus produtos, que não estavam sendo contempladas.

Mesmo que em muitas vezes esse tipo de conhecimento não seja necessariamente desenvolvido em alguns dos municípios da localidade deste estudo, por ocasião de eventos como a Hortitec e Enflor (que segundo ele é um dos principais eventos de arte floral em termos mundiais), esse conhecimento é apresentado e repassado a muitos produtores e demais componentes do sistema agroindustrial em apreço.

Apesar dessas vantagens, para o presidente da Câmara Setorial de Flores, não se pode dizer que a localidade de Holambra seja a mais importante no contexto geral da floricultura paulista e nem que seja a localidade que apresenta melhores condições para o desenvolvimento desse tipo de negócio. Sem dúvida, considera ser uma das mais importantes, mas não é capaz de afirmar ser é a mais importante. Se for considerada em termos de volume comercializado, não tem dúvida de que passa a ser a mais importante do país, mas por outro lado, se o fator analítico for à produção de espécies específicas (aspecto não menos importante para o compito geral do setor), essa liderança é compartilhada com outras regiões. Como exemplo, o entrevistado apontou algumas espécies de orquídeas que só se desenvolvem sob as condições climáticas da região de Mogi das Cruzes.

A localidade de Mogi das Cruzes para o representante da Câmara Setorial de Flores também oferece muitas vantagens para o cultivo do negócio de flores. Muitas delas semelhantes às apresentadas em Holambra: competências específicas desenvolvidas na própria localidade, identidade cultural e proximidade aos grandes centros de distribuição. Com relação a essas duas localidades, faz duas colocações importantes: a região de Mogi das Cruzes apresenta uma vantagem logística em comparação a Holambra pois está muito próximo da Rodovia Presidente Dutra (BR 116) e da Fernão Dias (BR 381). Por outro lado, a identidade cultural de Holambra gerou uma vantagem comparativa com relação à localidade de Mogi das Cruzes, uma vez que em Holambra a cultura cooperativista é historicamente mais presente. Ressalta que a Região de Mogi das Cruzes era extremamente dependente da Cooperativa Agrícola de Cotia $(\mathrm{CAC})$ e que a sua crise teve reflexos muito mais 
intensos para a economia e os agronegócios local do que os efeitos que a crise da Cooperativa Agropecuária de Holambra trouxeram para a localidade de Holambra.

Por fim, o entrevistado destaca que o papel do cooperativismo na construção das vantagens competitivas para os agronegócios de flores e plantas ornamentais tem sua relevância histórica, inclusive para outros setores da agricultura, mas não se pode dizer que tenha sido o principal ou um dos principais fatores de sucesso. É importante no conjunto.

\subsubsection{Companhia de Entrepostos e Armazéns Gerais de São Paulo - CEAGESP}

A entrevista com a chefe do centro de qualidade em horticultura da CEAGESP foi focada basicamente em três pilares de investigação, relacionados especificamente às atividades desenvolvidas pelo entreposto, e relacionadas ao objeto deste estudo: qualidade no negócio de flores e plantas ornamentais; as formas de comercialização e ao papel do cooperativismo e associativismo na construção da base competitiva da floricultura.

Com relação ao fator "qualidade" no sistema de produção de flores e plantas ornamentais, existe ainda a necessidade de que sejam estabelecidos parâmetros unificados, para a classificação desses produtos no mercado. Segundo a entrevistada, várias tentativas foram feitas no sentido de buscar padrões de qualidade para o setor, mas nenhuma foi efetivamente colocada em prática. Essas tentativas incluíram entidades como o próprio CEAGESP, o IBRAFLOR e as grandes cooperativas, como o Veiling em Holambra,

A inexistência desse tipo de padronização para os diversos tipos de flores e plantas ornamentais dificulta muito o processo de comercialização, na medida em que, entre outras medidas, as grandes cooperativas e grandes agentes de comercialização estabelecem seus próprios critérios de qualidade, como o caso do Veiling. Algumas até criam sua estrutura própria de auditorias nos produtores. Isso, segundo a entrevistada, tem trazido prejuízos ao setor, inclusive quando se busca a conquista de novos mercados internacionais.

Dependendo do produtor e da forma como esse viabiliza seu comércio, num mesmo lote de venda é comum observar plantas com hastes e flores em diferentes 
estágios de desenvolvimento ou com problemas fitossanitários. No entanto, a entrevistada argumenta que estes problemas ocorrem principalmente quando são produtores dissociados de qualquer estrutura maior de comercialização, que são aqueles que freqüentemente comercializam seus produtos na CEAGESP.

Com relação às formas de comercialização e ao papel do cooperativismo no contexto dos agronegócios de flores e plantas ornamentais, a gerente afirma que há uma interseção muito forte entre esses dois assuntos. Numa abordagem conjunta, destaca que a via de comercialização através das cooperativas traz inúmeras vantagens ao produtor rural, uma vez que quando ele vai diretamente a CEAGESP, o risco de seu negócio aumenta consideravelmente, já que ele não tem nenhum tipo de formalização da atividade de venda e nem sempre conhece seu cliente.

Além disso, ressalta que, o ambiente de comercialização na CEAGESP vai transferindo com o passar do tempo, maior poder de barganha ao comprador, uma vez que o caráter perecível das flores e plantas, impossibilita que o produtor a leve de volta e contabilize sua perda. Isso aumenta a rivalidade entre os produtores, que passam a trabalhar em competição crescente, trazendo ainda maiores vantagens ao comprador.

Assim, a entrevistada reforça o papel das cooperativas que atuam nesse processo de comercialização, pois são capazes de aumentar o poder de barganha dos produtores, promover uma melhor capacidade de inserção desses em mercados que requerem maiores volumes de produção, já que individualmente seria muito mais difícil alcançar esses mercados. Além disso, a questão da qualidade, também pode ser mais bem explorada pelas cooperativas.

\subsection{ANÁLISE GLOBAL DOS RESULTADOS QUALITATIVOS}

Conforme descrito no inicio deste capítulo, a análise e discussão dos dados qualitativos dessa pesquisa serão desenvolvidos de forma sintética em função das proposições apresentadas no Capitulo 3 e com base nos dados secundários levantados nesse estudo, sobretudo aqueles apresentados no Capítulo 4. 


\subsubsection{Considerações sobre a Proposição 1}

Proposição 1. A concentração geográfica de empresas do agronegócio de flores cria condições para promover maior número de ações conjuntas (joint actions), sendo que esta interação entre empresas é um importante fator gerador das vantagens competitivas presentes nos agrupamentos locais

Para as duas localidades estudadas, a importância da concentração geográfica dos produtores rurais na geração de melhores condições para a criação de ações conjuntas está associada a um processo imigratório especifico, que proporcionou em um primeiro momento a concentração dos produtores, que posteriormente passaram a se organizar em associações e cooperativas que lhes permitiram melhores condições competitivas. As cooperativas e associações de produtores locais representam tipicamente a forma organizada como principalmente os produtores das localidades estudadas, desenvolvem suas ações conjuntas.

A percepção predominante nas duas localidades, principalmente no que concerne às questões do Bloco 2, mostra que o desenvolvimento dessas ações conjuntas está relacionada a quatro motivos principais: participação em feiras ou eventos similares, atividades de capacitação (cursos e dias de campo), acesso a novidades tecnológicas e desenvolvimento ou melhoria de insumos, produtos ou processo. Esses motivos, também foram destacados nos Cassiolato e Lastres (2001), Suzigan et al. (2001) e Câmara et al. (1999). Os dois primeiros estudos mais relacionados à tecnologia e comercialização, enquanto que o terceiro enfoca também a questão das ações voltadas a treinamento e capacitação, como é o caso das atividades denominadas "dia de campo".

Os resultados apresentados anteriormente, para as duas localidades, mostram que as ações conjuntas são reconhecidas pelos atores locais como sendo importantes no processo de geração das vantagens competitivas locais. Esses resultados ficaram muito evidentes nos dois grupos pesquisados na localidade de Mogi das Cruzes e especialmente evidenciados nos grupos representados pela Cooperativa e pelas "Empresas Meio". Para as associações de produtores da localidade de Holambra, pode-se observar que a percepção mais evidente quanto à promoção de condições para o estabelecimento das ações conjuntas, está muito 
mais associada à "prática associativista" do que especificamente relacionada à proximidade dos agentes de produção.

Nas duas localidades, a prática de ações conjuntas se mostrou substancialmente relacionadas às parcerias desenvolvidas entre os produtores rurais, sobretudo em Holambra. Isso em parte pode ser explicado por essa proximidade gerada pelas "praticas associativistas", uma vez que a grande maioria dos produtores rurais é vinculada a algum tipo de associação ou cooperativa local.

A construção dessas organizações de produtores, principalmente na localidade de Holambra, foi o grande passo inicial para a aproximação de um numero maior de atores da cadeia de flores e plantas ornamentais, através da Cooperativa Agropecuária de Holambra e posteriormente das outras cooperativas que se instalaram na localidade. No caso da localidade de Mogi das Cruzes, essa organização se deu inicialmente, muito mais voltada para outras atividades do agronegócios (hortifrutigranjeiros), tendo a Cooperativa Agrícola de Cotia, o papel de principal condutor desse processo e posteriormente, com a estruturação da AFLORD e mais recentemente da SP Flores, o direcionamento especifico para os negócios de flores e plantas ornamentais.

Também em ambas as localidades, ficou bastante evidenciado que as percepções relativas as práticas as ações conjuntas entre os produtores rurais foram estabelecidas independentemente do tipo de espécies cultivadas. Isso mostra a prática indistinta de cooperação horizontal e/ou vertical (SCHIMTZ, 1997). Essa percepção foi bem acentuada, especialmente para a localidade de Holambra.

No que se refere às ações conjuntas desenvolvidas entre os demais atores da cadeia produtiva estudada, incluindo aquelas desenvolvidas com os produtores rurais, em ambas as localidades, esse tipo de ação foi considerado muito baixa.

Apesar do caráter étnico e imigratório ser marcante nas duas localidades estudadas, a percepção apresentada na análise dos dados qualitativos mostra que esse não é um aspecto fundamental para a o favorecimento do desenvolvimento de ações conjuntas entre os membros da localidade, apesar de ter sido fundamental para o início do processo histórico de estruturação das cooperativas e associações locais. Entretanto, isso não significa que a condição étnica não interfira no processo de estabelecimento dessas ações, pois essa influência não foi descartada pelos grupos estudados, no entanto não apresenta papel decisivo no processo. Suzigan et al. (2001) destacam que as questões políticas, culturais e sociais constituem a base 
da confiança e do compartilhamento de informações entre os membros de uma dada concentração geográfica.

A dificuldade de se dissociar a influencia étnica em Mogi das Cruzes foi bem destacada pelos grupos respondentes dessa localidade, uma vez que a presença de membros sem ascendência nipônica é mínima e no caso dos produtores rurais, nula. Já na localidade de Holambra, onde existe uma maior miscigenação de etnia, a questão étnica assume relevância bem inferior e foi desconsiderada para a maioria dos grupos respondentes.

Neste estudo, a análise dos resultados qualitativos obtidos nas duas localidades, mostra que a base para o desenvolvimento das ações conjuntas, está no histórico das ações desenvolvidas entre os produtores, principalmente amparado pelo o aparato tanto das cooperativas como das associações. Ficou evidenciado também que a confiança de parcerias já de longo prazo, fortalece o desenvolvimento de ações conjuntas.

Em síntese, dois aspectos mostram-se relevantes no processo de desenvolvimento das ações conjuntas nas localidades estudadas: a presença de organizações associativas ou cooperativas e a proximidade cultural e geográfica.

Esse cenário mostra que há, nas duas localidades estudadas, a percepção por parte dos grupos respondentes, da prática de cooperação associada à competição, confirmando com isso a Proposição 1, elaborada no inicio deste estudo.

\subsubsection{Considerações sobre a Proposição 2}

Proposição 2. A concentração geográfica de empresas cria externalidades incidentais, que se mostram determinantes para a competitividade das empresas e da localidade.

Os resultados da pesquisa qualitativa, mostram que as duas localidades estudadas são responsáveis pela geração de externalidades positivas, de ampla significância para o desempenho dos negócios de flores e plantas ornamentais. Essas externalidades forma majoritariamente relatadas no Bloco 3. 
Tanto na localidade de Mogi das Cruzes como na localidade de Holambra, a percepção quanto à presença de mão-de-obra de alto nível, referente as principais atividades de comercialização e produção, foram intensamente reportadas.

A geração de competências específicas também foi intensamente reportado nas duas localidades pela maioria dos grupos estudados. Vale salientar que as atividades de treinamento e capacitação, foram evidenciadas nas localidades como sendo um das principais ações indutoras para o estabelecimento de ações conjuntas, conforme discutido anteriormente.

Com relação à presença de representantes das indústrias correlatas e de apoio, foi possível observar na localidade de Holambra, representadas no grupo “Empresas Meio", a presença marcante desse tipo de empresa, não só sediadas na localidade como também aquelas que apresentam fortes laços de relacionamento com Holambra.

Também, na localidade de Holambra, foi possível observar a presença de antigos empregados rurais que acabaram por desenvolver seu próprio negócio, caracterizando um típico caso de transbordamento (spillover) tanto ao nível de conhecimento como ao nível tecnológico. Esses produtores, conforme relatou o presidente da Câmara Setorial de Flores e Plantas Ornamentais, são em sua grande maioria, cooperados de uma das cooperativas de pequeno porte da localidade.

Os resultados destacados por Cassiolato e Lastres (2001) foram evidenciadas através da percepção dos entrevistados nas duas localidades, relatadas principalmente no Bloco 3 para cada um dos grupos pesquisados, englobando a percepção de todos os grupos para cada um das localidades.

As principais fontes de informação para a construção das competências locais foram identificadas por todos os grupos participantes desta pesquisa qualitativa. $\mathrm{Na}$ localidade de Holambra a principal fonte de informação foi à participação em feiras e eventos, que se destacou com mais de $80 \%$ de indicações entre os grupos de entrevistados.

Nesse sentido, é possível observar que em Holambra, a realização da Hortitec ou do Enflor, considerados dois eventos referenciais na floricultura nacional, que só são possíveis devido à estrutura que hoje se tem presente na localidade, revela ainda que esses eventos favorecem a construção dos meios de comunicação considerado o mais importante. 
Com relação à localidade de Mogi das Cruzes, foi destacada a associação de produtores rurais, a AFLORD, que desenvolve atividades sistemáticas de pesquisa e extensão para seus associados, como uma fonte segura de geração de informações para atualização tecnológica e para manter seus produtores atualizados, tanto em nível técnico de produção, como em nível de mercado e fontes de financiamento, haja visto, que seus associados são, segundo percepção da própria associação, bem informados a esse respeito.

Isso posto, tem-se que o desenvolvimento do estudo qualitativo nas localidades de Holambra e Mogi das Cruzes, confirmam a Proposição 2.

\subsubsection{Considerações sobre a Proposição 3}

Proposição 3. O desempenho competitivo das empresas depende das relações sistêmicas e das condições de governança na cadeia de valor no qual estão inseridas

De maneira geral, nas duas localidades pode-se observar que os grupos estudados, a exceção do grupo "Empresas Meio", apresentam um razoável conhecimento do potencial do mercado em que atuam. Os grupo também apresentaram uma perspectiva de crescimento, tanto ao nível interno como externo. Esses dados são concordantes aos estudos realizados pelo IBRAFLOR e que são contemplados no planejamento estratégico dessa entidade para 2007 (IBRAFLOR, 2006).

Não obstante, com relação ao conhecimento da dinâmica dos principais concorrentes, fornecedores e clientes, observou-se um certo desconhecimento do posicionamento de mercado das empresas, tanto por parte das associação de produtores como de alguns agentes de comercialização. Somente a Cooperativa Veiling de Holambra mostrou ter uma percepção maior a esse respeito, na medida em que foi capaz de identificar, seus principais clientes, fornecedores e concorrentes. Essa cooperativa identificou seu poder de barganha junto a seus principais clientes e fornecedores e mostrou que não identifica nenhum concorrente de porte significativo que possa compor algum tipo de ameaça aos seus negócios. 
Isso mostra que em termos de acesso a mercado e ameaças da concorrência, os cooperados do Veilng, em conjunto, estão bem posicionados nesse mercado, no entanto, com relação aos seus principais fornecedores (área em que a cooperativa não atua), esse cenário é diferente.

Para os outros grupos de entrevistados (Entidades de Apoio e Associação de Produtores Rurais), a percepção foi que a maioria das empresas e produtores rurais depende fortemente de alguns fornecedores e que possuem menor poder de barganha, principalmente quando relacionados ao setor de insumos e máquinas. Apesar de existir uma cooperativa na localidade de Holambra, voltada para a área de insumos, o acesso à ela é restrito a determinados perfis de produtores, conforme discutido anteriormente. Assim, alguns produtores, como o caso dos associados da AAFHOL, buscam criar novas alternativas, como estabelecer uma estrutura de compra conjunta, visando diminuir essa situação desfavorável a eles. O mesmo tipo de raciocínio é que levou aos produtores da localidade de Mogi das Cruzes a montarem uma cooperativa, que entre outros benefícios, traria maior poder de barganha junto aos seus clientes, na medida em que teria maior volume e mix de produto a ser oferecido no mercado.Já com relação à identificação dos principais clientes e da concorrência dos produtores rurais, esses dois grupos, em ambas as localidades, mostram que não se pode fazer uma identificação mais precisa, na medida em que os produtores cultivam várias espécies e a concorrência é determinada em função das espécies cultivadas.

A presença de um agente de coordenação na cadeia produtiva foi um, fator destacado na localidade de Holambra, como sendo responsável pelo desempenho competitivo dos produtores rurais, que contribui sobremaneira para a construção de uma base competitiva na localidade. Apesar desse fator não ter sido tão enfatizado na localidade de Mogi das Cruzes, os produtores da localidade já contam com uma cooperativa de comercialização e distribuição de seus produtos, o que visa atuar à semelhança da Cooperativa Veiling de Holambra.

Nas duas localidades a percepção foi unânime no sentido de destacar que a qualidade dos produtos e/ou serviços oferecidos como o principal fator associado ao sucesso dos negócios locais, seguido da confiança de seus clientes. O preço, não foi considerado como um fator decisivo em nenhum dos grupos.

Foi apontada como um gargalo, a questão da ausência de padronização de qualidade para o setor de flores e plantas ornamentais, o que dificulta as transações 
comerciais ao longo da cadeia como um todo. Assim, para atender ao principal requisito do mercado, cada agente de comercialização definiu seus próprios requisitos para padronização de seus produtos que é repassado para os produtores.

Com relação às estratégias financeiras, de modo geral, ficou evidenciada a percepção de que a alta burocracia e, sobretudo para as pequenas e médias empresas do grupo "Empresas Meio" e a dificuldade de acesso aos agentes financeiros, faz com que os agentes locais passem a buscar fontes próprias para financiamento de seus atividades. Na maioria dos casos, quando há um acesso mais facilitado, esse é prioritariamente feito através de órgãos públicos de fomento, levando inclusive à formação de associações, para que esse acesso fosse viabilizado, como foi ocaso dos pequenos produtores dos municípios de Holambra e Arthur Nogueira.

Em síntese, os resultados obtidos na parte da pesquisa qualitativa deste estudo, permitem a confirmação da proposição 3, relacionadas ao desempenho estratégica e gerencial dos negócios desenvolvidos.

\subsubsection{Considerações sobre a Proposição 4}

Proposição 4. No contexto dos agronegócios de flores e plantas ornamentais, instituições de governo em suas várias esferas podem induzir ações cooperativas entre os componentes de uma localidade, atuando como agentes coordenadores, gerando com isso influencias importantes nas estratégias competitivas das empresas da localidade, tanto ao nível individual quanto em nível coletivo.

Especificamente com relação ao papel do poder público na coordenação de atividades que possam incentivar a parceria entre os membros do sistema agroindustrial estudado, a percepção predominante nos vários grupos nas duas localidades é que não existem ações significativas do poder público no sentido de fomentar a competitividade do setor. Além disso, a própria estrutura governamental, especificamente voltada para a extensão rural, a CATI, se mostrou extremamente distante dos produtores rurais, conforme destacado pelos respectivos grupos 
respondentes. Não houve qualquer menção de atividades de parceria com esse órgão público. Por outro lado, foi possível observar que nas duas localidades houve relatos de projetos específicos de organismos de governo, ambos desenvolvidos com a participação do SEBRAE, voltados para o setor de flores e plantas ornamentais.

A realização de eventos importantes para ambas localidades, tais como Hortitec e Enflor, conta também com a participação e apoio do poder público local.

Destaca-se, finalmente, que na localidade de Mogi, os respondentes foram mais enfáticos nas críticas a infra-estrutura do CATI e relataram de forma negativa a assistência técnica governamental, cujas carências estruturais foram alvo de análises anteriores.

Neste contexto, não foi possível levantar evidências que confirmem a Proposição 4 desta tese. 


\section{CAPÍTULO 6. RESULTADOS DA PESQUISA QUANTITATIVA}

Neste capítulo é feita a apresentação dos resultados empíricos da pesquisa quantitativa do tipo levantamento (survey). Os questionários foram aplicados por ocasião da realização de reuniões ou assembléias das cooperativas ou associações de produtores, direcionados aos responsáveis pela produção de flores nas unidades agrícolas de produção das duas localidades estudadas. No total foram obtidos 90 questionários válidos. Observa-se que cada questionário corresponde a uma unidade agrícola, nos casos em que responderam mais do que um questionário da mesma unidade, optou-se pelo respondente de maior nível hierárquico.

O capítulo conclui com a discussão dos resultados da pesquisa tipo levantamento (survey), elaborada a partir das hipóteses apresentadas na descrição metodológica do Capítulo 3. A semelhança dos resultados da pesquisa qualitativa, os dados secundários serão utilizados para subsidiar o processo de discussão e análise dos resultados.

\subsection{CARACTERIZAÇÃO GERAL DA AMOSTRA}

A amostra foi constituída de 90 entrevistados dos quais, 40 são holandeses ou descendentes de holandeses, 16 japoneses ou descendentes de japoneses, 34 apresentam outra ascendência que não holandesa nem japonesa, conforme ilustrado no Gráfico 6.1. 


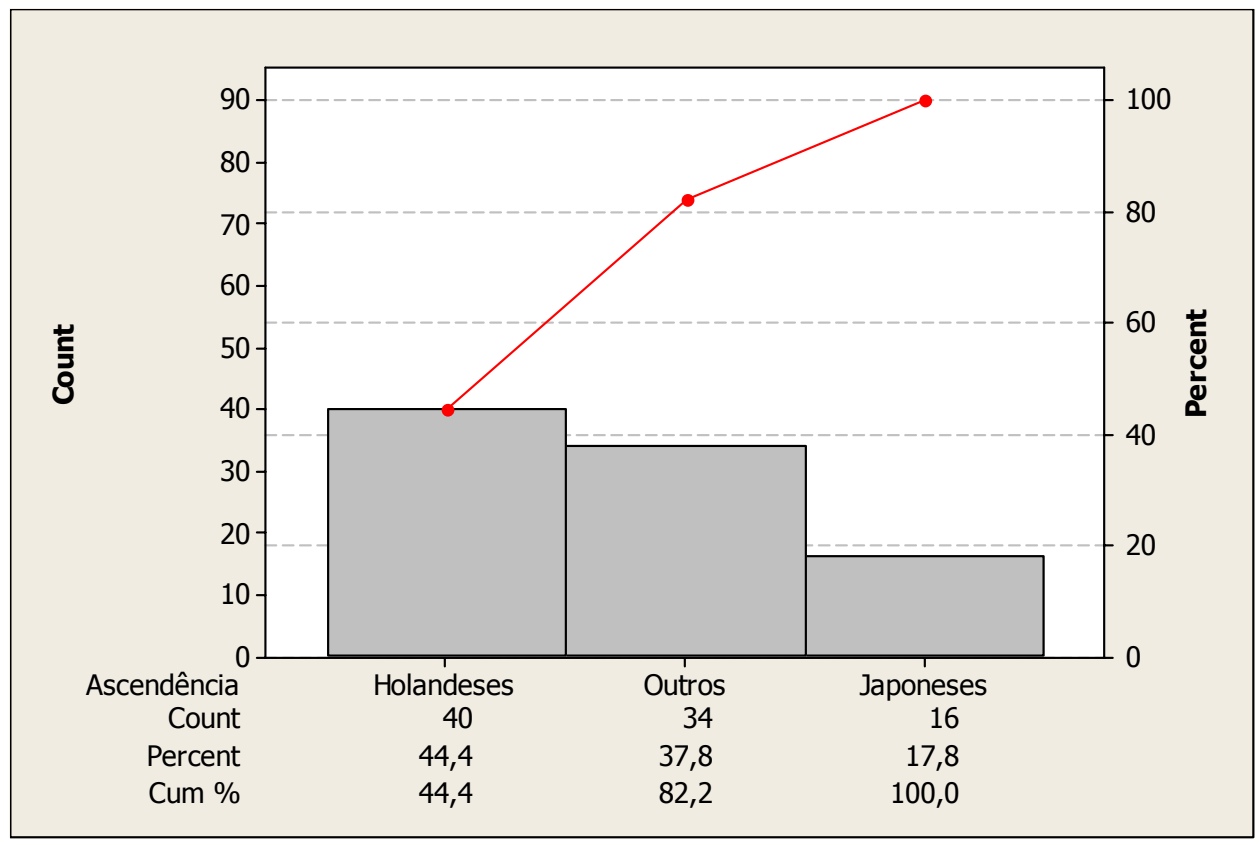

Gráfico 6.1. Distribuição proporcional dos principais grupos étnicos do universo de produtores rurais entrevistados nas duas localidades. (Fonte: o autor)

A maioria desses produtores possui mais de quinze anos de experiência na produção de flores e plantas ornamentais (ver Gráfico 6.2).

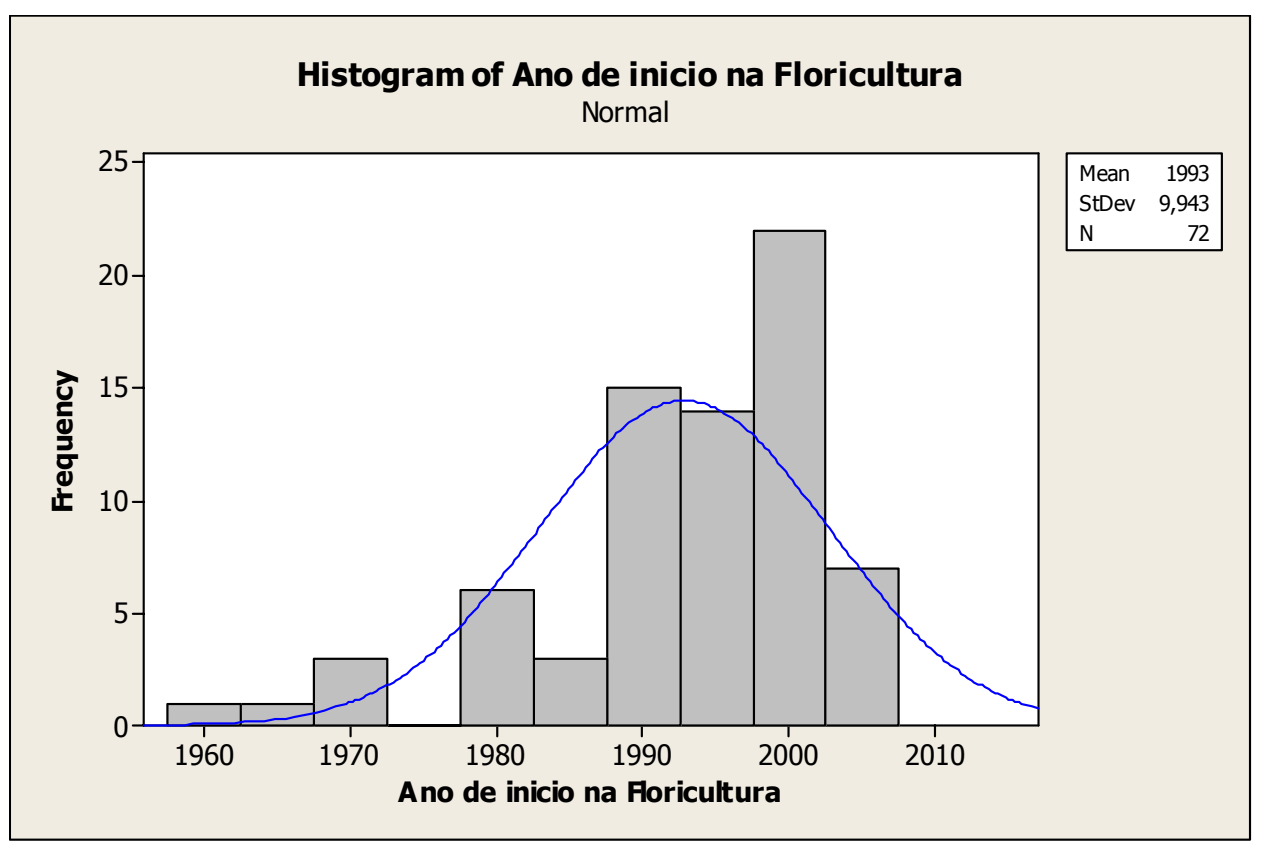

Gráfico 6.2. Distribuição proporcional dos produtores em função do ano de inicio nas atividades agrícolas de produção de flores e plantas ornamentais. (Fonte: o autor)

No compito geral, o conhecimento adquirido através do estudo próprio, foi a principal origem do conhecimento técnico necessário para o desenvolvimento do 
negócio, seguido do convívio com os demais produtores da localidade, conforme pode ser observado no Gráfico 6.3. Esse resultado foi também destacado em primeiro lugar pelos produtores holandeses ou com descendência holandesa. Em seguida, foram destacados o convívio com outros produtores da localidade seguido do fator aprendizado em propriedade onde trabalhava.

Destaca-se, no entanto, que, ao se estratificar as respostas por etnia/ ascendência, ocorre inversão nesta classificação. Por exemplo, o fator tradição familiar, que não aparece entre as primeiras colocações do compito geral é classificado em segundo lugar pelos produtores de origem ou ascendência holandês e empata em primeiro lugar, nos produtores japoneses ou descendentes. Já para os produtores sem ascendência nem holandesa nem japonesa (outros), observa-se que os fatores mais importantes foram o aprendizado em propriedade onde trabalhava e o convívio com outros produtores da localidade. Isso mostra haver um indício da existência de externalidades incidentais nas localidades estudadas.

O Gráfico 6.3 apresenta os resultados estratificados por fatores, por classe de etnia/ascendência e também o geral da amostra.

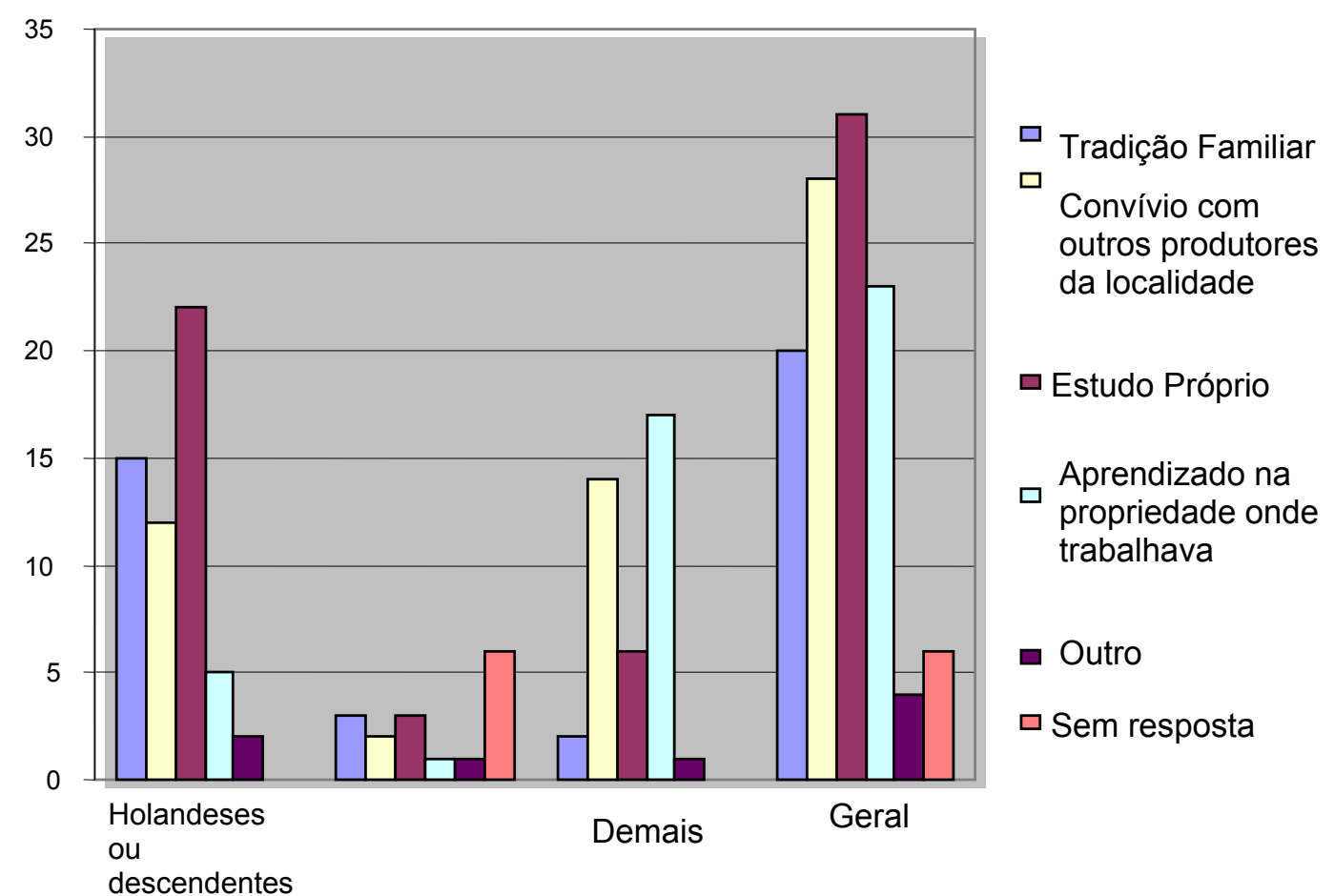

Origem do Conhecimento Técnico

Gráfico 6.3 Distribuição proporcional dos produtores em função da origem étnica e as principais origens do conhecimento técnico necessário para o desenvolvimento dos negócios (Fonte: o autor) 
Dos produtores rurais pesquisados, $67(74,6 \%)$ estão sediados na localidade de Holambra, dez $(11,1) \%$ na localidade de Mogi das Cruzes e treze $(14,3 \%)$ em municípios que não pertencem a essas duas localidades. Todos os produtores sediados fora das localidades estudadas, são cooperados de ao menos uma, das três cooperativas de comercialização de flores da localidade de Holambra e, por esse motivo, foram considerados como pertencentes a ela. Os produtores da localidade de Mogi das Cruzes não identificaram o município de sua sede, considerando sempre "Mogi das Cruzes". Das Unidades Agrícolas de Produção (UAP) estudadas, $72 \%$ desenvolvem suas atividades em ambiente protegido (estufas ou telados). O Quadro 6.1 mostra a distribuição detalhada da localização dessas Unidades Agrícolas de Produção.

Quadro 6.1. Distribuição das Unidades de Produção nos municípios componentes das duas localidades estudadas

\begin{tabular}{|c|c|c|}
\hline & UAPs & $\%$ \\
\hline \multicolumn{3}{|l|}{ Localidade de Holambra } \\
\hline Holambra & 51 & 56,8 \\
\hline Santo Antonio de Posse & 1 & 1,1 \\
\hline Arthur Nogueira & 12 & 13,4 \\
\hline Mogi Mirim & 2 & 2,2 \\
\hline Campinas & 1 & 1,1 \\
\hline Total de UAPs da Localidade de Holambra & 67 & 74,6 \\
\hline \multicolumn{3}{|l|}{ Localidade de Mogi das Cruzes } \\
\hline Não Informado & 10 & 11,1 \\
\hline \multicolumn{3}{|l|}{$\begin{array}{c}\text { Municípios não pertencentes às localidades } \\
\text { estudadas }\end{array}$} \\
\hline Itupeva & 1 & 1,1 \\
\hline Várzea Grande Paulista & 1 & 1,1 \\
\hline Cotia & 1 & 1,1 \\
\hline Ibiúna & 2 & 2,1 \\
\hline São Roque & 1 & 1,1 \\
\hline Andradas - MG & 1 & 1,1 \\
\hline Não Informado & 6 & 6,7 \\
\hline Total de UAPs situadas fora das Localidades & 13 & 14,3 \\
\hline Quantidade de Questionários Válidos & 90 & 100 \\
\hline
\end{tabular}

Seguindo o critério de seleção dos entrevistados, todos os produtores considerados neste estudo são associados de ao menos uma das cooperativas de 
comercialização, presentes em sua respectiva localidade. Há apenas um produtor, localizado no município de Holambra,que pertence a duas cooperativas de comercialização, das três existentes na localidade. Todos os produtores, em ambas as localidades, utilizam as organizações cooperativas para a comercialização de seus produtos, no entanto, três pequenos produtores da localidade de Holambra, vendem freqüentemente, parte de sua produção para atacadistas e apenas um vende parte de sua produção diretamente para o consumidor final. Somente os produtores da localidade de Mogi das Cruzes, mostram que, apesar de também estarem associados à cooperativa local, utilizam também desses outros meios, como atacadistas ou consumidores finais.

\subsection{RESULTADOS DA PESQUISA QUANTITATIVA}

Nesta seção serão apresentados os resultados dos questionários aplicados para cada localidade. A apresentação será feita por bloco do instrumento de pesquisa utilizado (ver Anexo B), sem considerar o primeiro bloco e parte do quarto bloco, cujos dados foram utilizados para a caracterização geral dos respondentes apresentada no item anterior.

\subsubsection{Bloco 2 - Parceria e Ação Conjunta}

Esse bloco teve como objetivo investigar a intensidade de ocorrência, a freqüência e as finalidades das parcerias que são desenvolvidas pelos produtores das duas localidades. Além disso, buscou-se identificar os fatores facilitadores dessas parcerias. Para tanto, foram elaborados conjuntos de questões relacionados à: identificação dos principais parceiros; freqüência com que essas parcerias foram estabelecidas; identificação dos principais agentes facilitadores desse processo e a identificação dos principais motivos dessas parcerias.

No primeiro conjunto de questões deste bloco foram apresentados onze possíveis parceiros, associadas a uma escala de freqüência assim determinada: 
nenhuma (0); baixa (1); média (2) e alta (3). Foi solicitado ao respondente identificar, para cada um dos possíveis parceiros, dentre a lista de opções, com qual freqüência desenvolve ações conjuntas.

Outro conjunto de questões foi estruturado de forma que o respondente assinalasse, dentre uma lista de motivos que levaram ao estabelecimento das ações conjuntas, uma ou mais opções.

Com relação à identificação da freqüência de ações de parcerias desenvolvidas pelos produtores, os resultados da análise conjunta das duas localidades está ilustrada no Gráfico 6.4

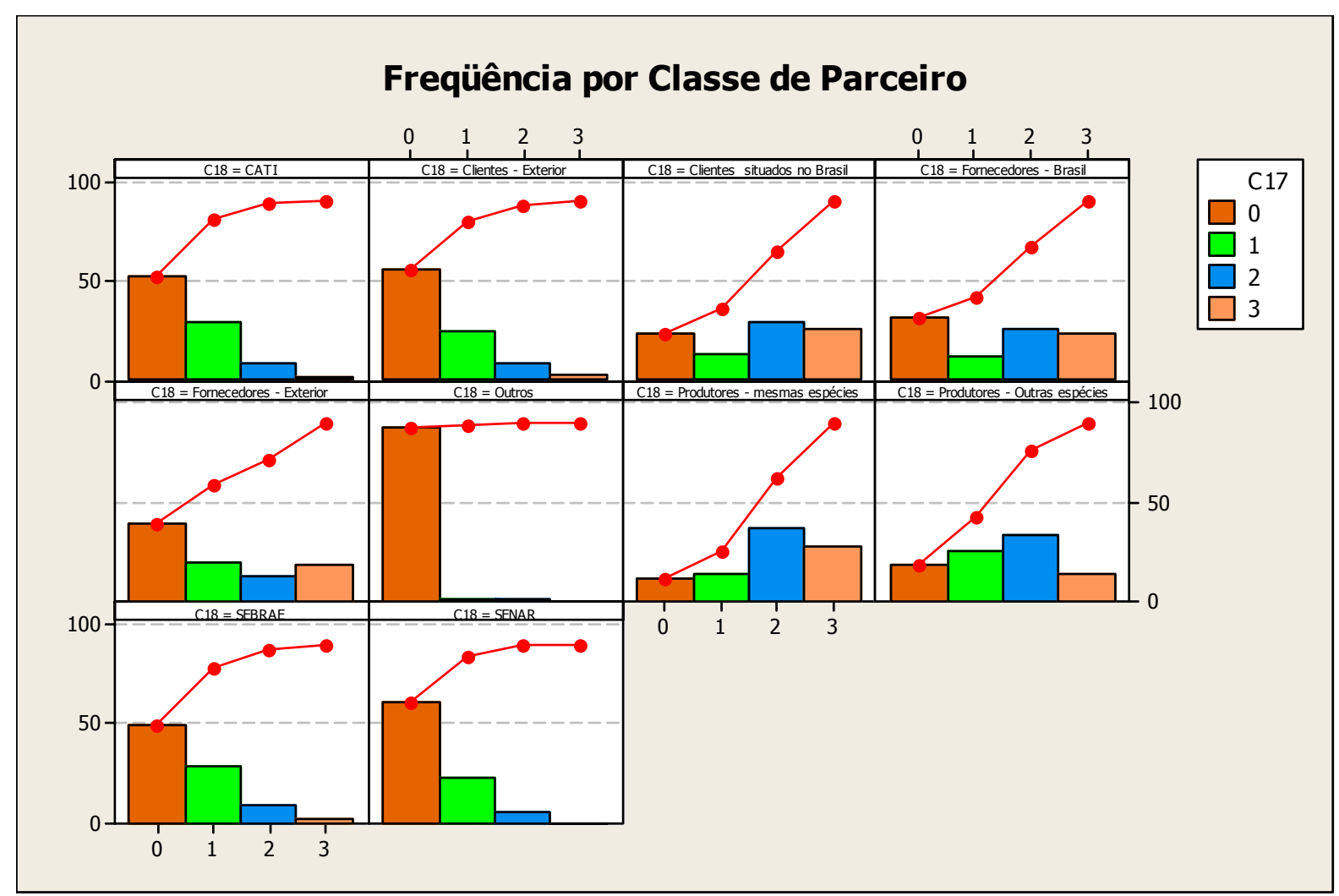

Gráfico 6.4 - Freqüência das ações conjuntas entre os produtores rurais Fonte: o autor

Os resultados desse gráfico mostram que aproximadamente $50 \%$ dos produtores entrevistados não fazem nenhum tipo de parceria com os agentes de governo ou organismos de pesquisa e que os poucos que fazem, ainda assim, apresentam uma baixa freqüência dessas ações. Por outro lado, esse mesmo gráfico mostra que nas parcerias com clientes situados no Brasil, predominam produtores que desenvolvem parcerias com média e alta freqüência, se comparadas aos produtores que não as desenvolvem ou as desenvolvem com baixa freqüência. 
Um outro resultado importante que pode ser observado no Gráfico 6.4 está relacionado ás parcerias desenvolvidas entre os produtores das localidades. Aqueles que desenvolvem esse tipo de parceria com média ou alta freqüência são em maior número do que aqueles que não as desenvolvem ou as desenvolvem com baixa freqüência.

O resultado observado para as parcerias desenvolvidas entre os produtores que cultivam as mesmas espécies (concorrentes, portanto) mostrou um numero maior de produtores que as fazem com intensidade a média e alta, quando comparado ás demais intensidades. Fica assim caracterizado ai a ocorrência do fenômeno da co-opetição (co-optetition) descrito por Porter (1998).

O fato da maior freqüência das ações de parceria estar relacionada aos produtores que cultivam as mesmas espécies entre si apresenta-se congruente aos motivos que os levaram a estabelecer essas parcerias. Dos quatro motivos mais relatados pelos entrevistados, três deles se relacionam às especificidades de cultivo: troca de informações e compartilhamento de idéias, compra conjunta de insumos e equipamentos e treinamento e capacitação de pessoal. O Gráfico 6.5 ilustra em termos percentuais, a relação de quanto cada motivo foi apontado em relação ao universo de produtores entrevistados.

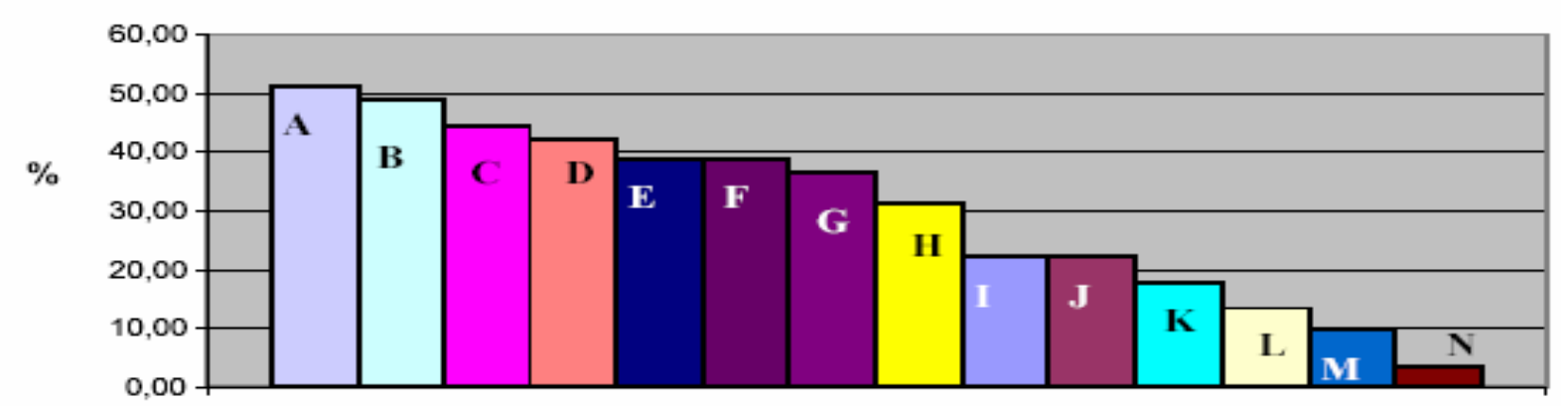

Motivos Indutores das Açöes Conjuntass

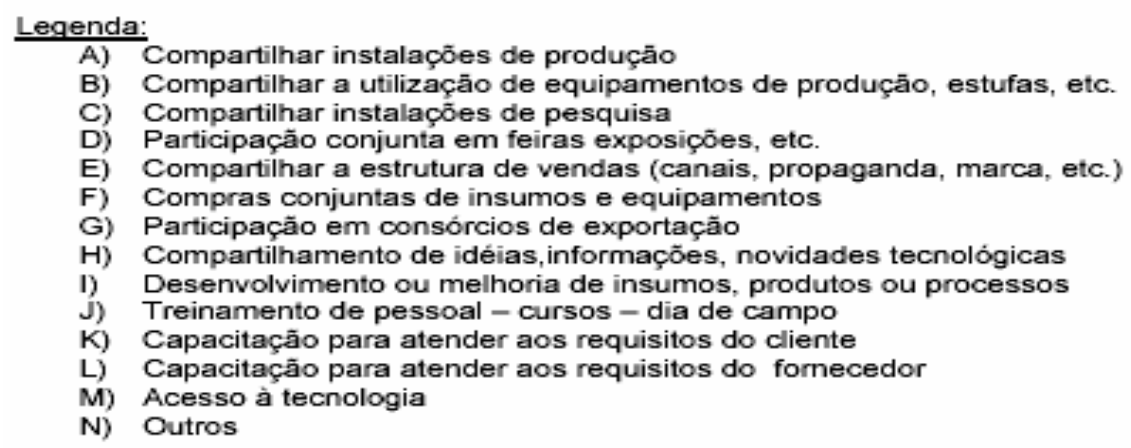

Gráfico 6.5 Motivos indutores para a realização de ações conjuntas entre os produtores rurais nas localidades de Mogi Mirim e Holambra (Fonte: o autor) 
O último conjunto de questões deste bloco relativo às parcerias, é composto por sete questões, descritas no Quadro 6.2. O respondente deveria apresentar sua percepção, segundo uma escala de Likert, pontuada da seguinte forma: Discordo (2), Indiferente (-1), Não sei ou não tenho opinião (0), Concordo Parcialmente (1) e Concordo (2).

Quadro 6.2 Questões relacionadas à investigação dos fatores associados ao desenvolvimento das ações de parcerias dos produtores rurais das localidades estudadas

1. "A maioria das ações de parcerias e/ou cooperação que estabeleci com outros produtores, clientes, fornecedores ou outras empresas da floricultura surgiu através de laços familiares".

2. "A maioria das ações de parcerias e/ou cooperação que estabeleci com outros produtores, clientes, fornecedores ou outras empresas da floricultura, surgiu do convívio com outros produtores da cooperativa e/ou associação de produtores a que sou filiado."

3. A maioria das ações de parcerias elou cooperação que estabeleci com outros produtores, clientes, fornecedores ou outras empresas da floricultura, surgiu da comunidade étnica da qual sou descendente

4. "A maioria das ações de parcerias e/ou cooperação que estabeleci com outros produtores, clientes, fornecedores ou outras empresas da floricultura, surgiu consolidação das relações comerciais, com o tempo"

5. A maioria das ações de parcerias e/ou cooperação que estabeleci com outros produtores, clientes, fornecedores ou outras empresas da floricultura, surgiu pelo incentivo ou intermediação da cooperativa e/ou associação de produtores a qual sou filiado."

6. "A maioria das ações de parcerias e/ou cooperação que estabeleci com outros produtores, clientes, fornecedores ou outras empresas da floricultura surgiu pelo incentivo/intermediação do Sindicato Patronal, e/ou Sindicato de trabalhadores; entidades como SEBRAE, SENAR, associação comercial local, etc."

7. "A maioria das ações de parcerias e/ou cooperação que estabeleci com outros produtores, clientes, fornecedores ou outras empresas da floricultura surgiu por que sei da importância delas para o fortalecimento da estrutura de produção e/ou comercialização da qual dependo.."

Fonte: o autor

As médias dos valores atribuídos para cada questão, representando o nível de concordância (escala de Likert) por parte dos entrevistados, em ambas localidades, estão representadas no Gráfico 6.6.

Nesse gráfico é possível observar a influência do convívio entre os produtores de uma mesma cooperativa e/ou associações de produtores rurais, para o estabelecimento de ação de parceria. Esse resultado pode ser observado pela média de resposta da Questão 2 que apresentou a maior média de concordância superior a 1,0. Em seguida vem a Questão 7, com um nível médio de concordância semelhante, que relacionada as ações de parceria para o fortalecimento da estrutura de produção e comercialização da qual dependem os entrevistados. Conforme 
observado na pesquisa qualitativa, (Capítulo 5) essa estrutura é toda ela montada em função das organizações cooperativas.

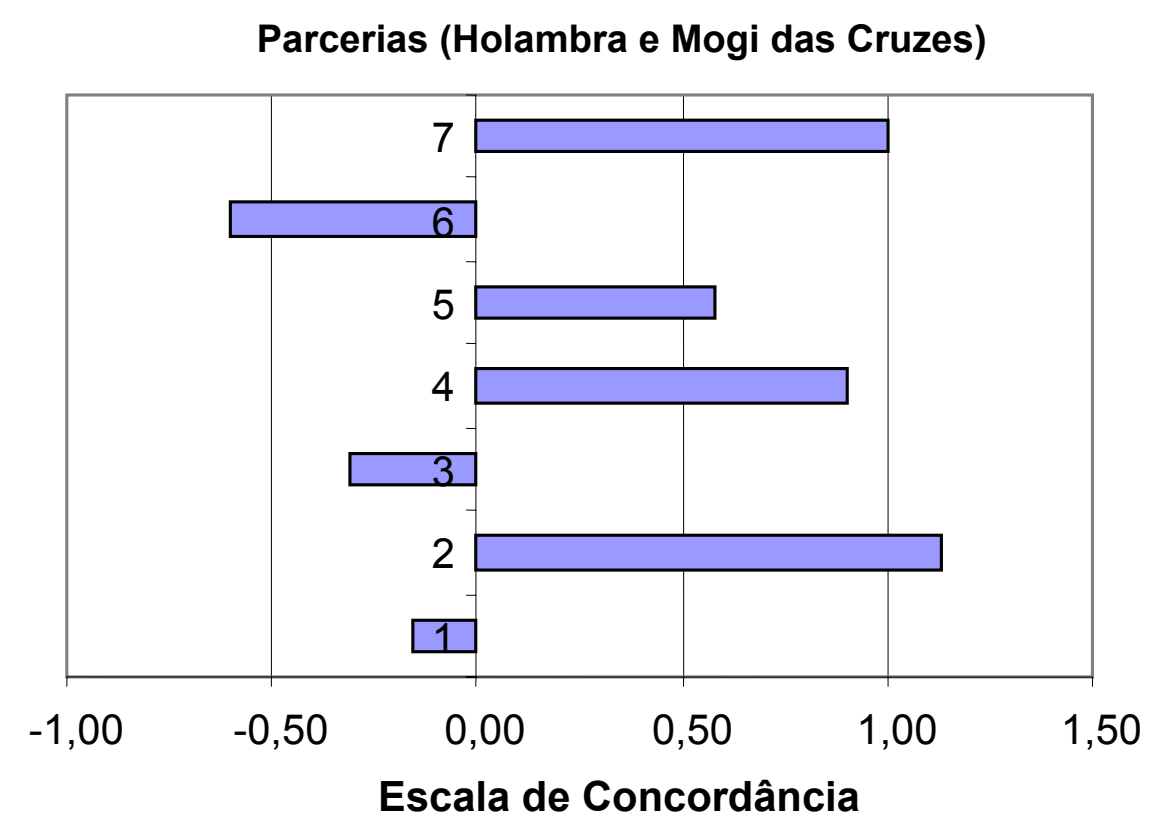

Gráfico 6.6- Média dos valores de concordância com as questões relativas às atividades de parcerias dos produtores rurais das localidades estudadas. (Fonte: o autor)

No compito geral, houve discordância nas Questões 1, 3 e 6, ou seja, a percepção predominante é que os produtores discordam da importância de laços familiares (Questão 1), da comunidade étnica (Questão 3) e dos sindicatos e entidades de apoio (Questão 6) na formação de ações de parceria.

A análise estratificada dos dados por localidade, ilustrada no Gráfico 6.7, mostra que quando é considerada somente a localidade de Mogi das Cruzes, o gráfico gerado apresenta-se algumas particularidades que apontam percepções distintas com relação a alguns fatores. Especificamente com relação às questões 1 e 3, sobre a percepção da influência dos laços familiares e da questão étnica nas ações de parcerias, respectivamente, houve inversão na percepção, ou seja, em Mogi das Cruzes os produtores concordam que este seja um fator que influencia enquanto os produtores de Holambra discordam. O resultado de Holambra assemelha-se ao geral, uma vez que esta localidade apresentou um número maior de produtores rurais entrevistados, quando comparado à localidade de Mogi Mirim. 
Observando-se o Gráfico 6.7, percebe-se que o grau de concordância da questão 7 manteve-se praticamente inalterado, enquanto que as questões 2, 4 e 6 apesar de terem mostrado diferenças nos valores médios das respostas, mantiveram o mesmo comportamento predominante de concordância e discordância, respectivamente.
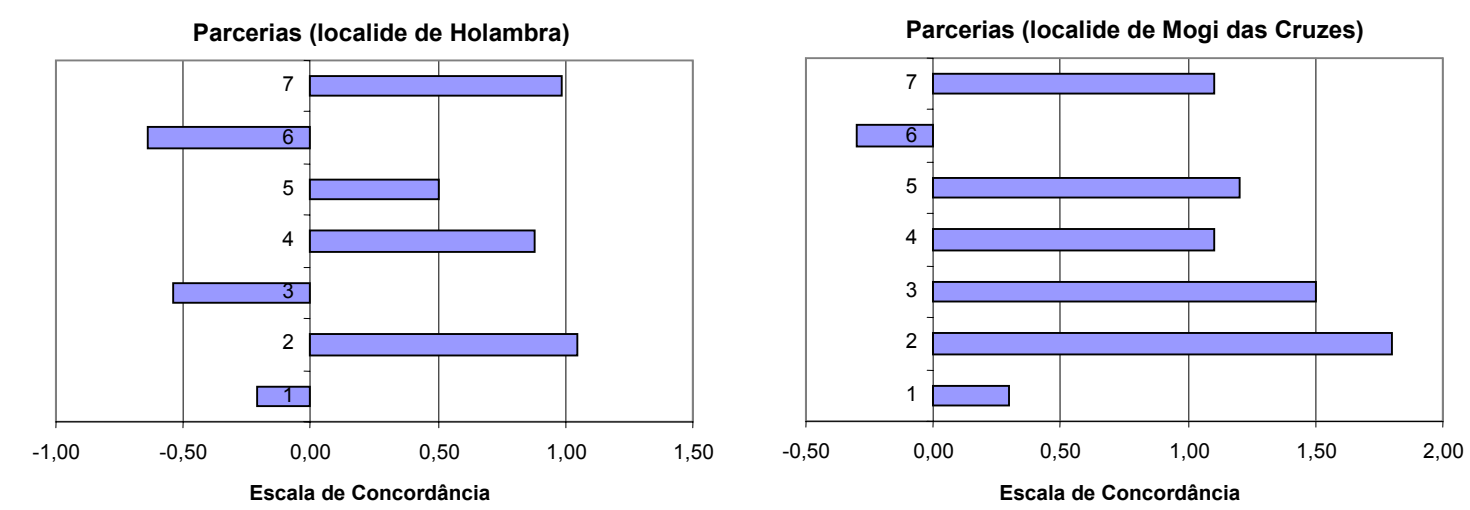

Gráfico 6.7. - Média dos valores de concordância com as questões relativas às atividades de parcerias dos produtores rurais das localidades de Holambra e Mogi das Cruzes, analisadas em separado (Fonte: o autor).

Com relação à média dos valores atribuídos às respostas da Questão 5 , o valor médio observado para a localidade de Mogi das Cruzes foi substancialmente maior. Isso dá indícios que nesta localidade, o trabalho desenvolvido por essas entidades, provavelmente seja mais efetivo, se comparado ao trabalho exercido pelas cooperativas e outras associações da localidade de Holambra.

Deste Bloco 1, a principal diferença observada entre as duas localidades foi referente a influencia dos laços familiares, da comunidade étnica sobre a formação de parcerias e sobre o papel das associações de apoio no incentivo ao desenvolvimento de parcerias e ações conjuntas. Essa diferença pôde ser também identificada na analise dos resultados qualitativos. 


\subsubsection{Bloco 3 - Localidade}

A construção deste bloco, teve como objetivo investigar o papel da localidade na geração de externalidades positivas. Para tanto, foi estruturado com 13 questões (ver Quadro 6.3), também em escala Likert, utilizando-se os mesmos níveis relatados anteriormente.

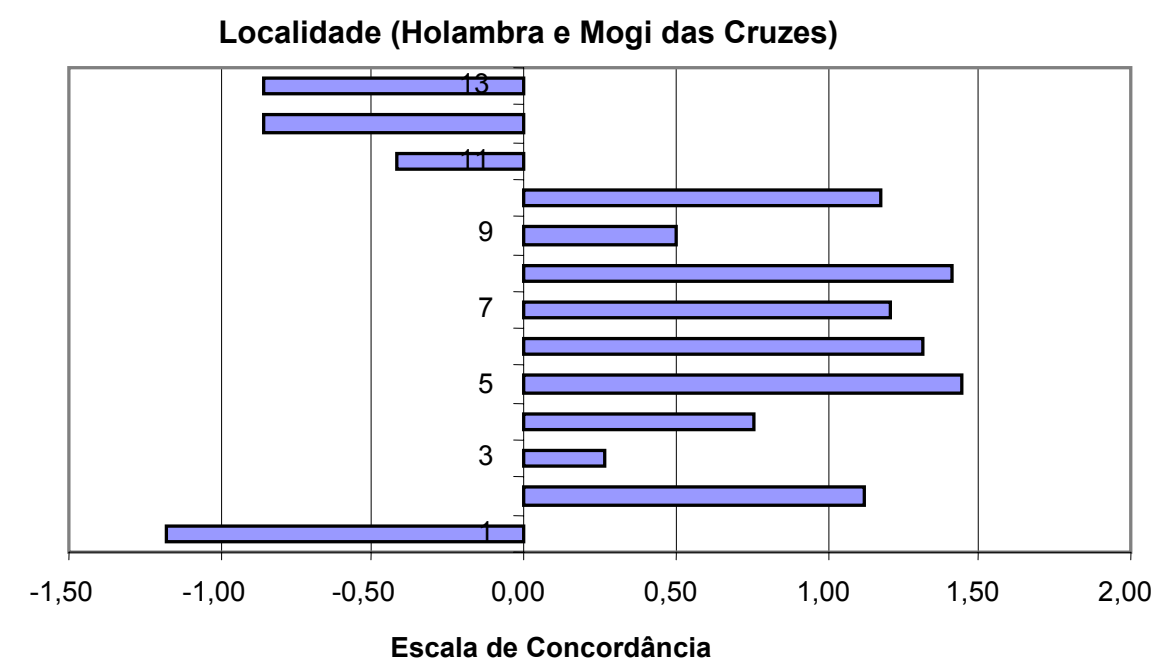

Gráfico 6.8 - Média dos valores de concordância com as questões relativas à percepção do papel da localidade na construção das vantagens competitivas dos negócios de flores e plantas ornamentais das localidades estudadas -análise conjunta. (Fonte: o autor)

A análise conjunta dos resultados obtidos nas duas localidades é apresentada no Gráfico 6.8, que mostra uma percepção predominante de que o poder público local (Questão 1) não interfere na promoção dos agronegócios locais. Foi o maior nível médio de discordância $(-1,18)$ dentre todas questões apresentadas. As questões que relatavam as desvantagens associadas às localidades - (11, 12 e 13) mostram a percepção predominante de discordância, embora apresente média inferior a 1,0 nas três questões. Este resultado é semelhante ao comportamento observado no estudo qualitativo apresentado no Capítulo 5.

Por outro lado, verificou-se elevada percepção de concordância com relação as vantagens destas localidades, em especial no que concerne ao reconhecimento como referência na produção de flores e plantas ornamentais, pela comunidade dos agronegócios em geral. Isso se encontra representado na Questão 5, cuja média da escala de concordância $(1,44)$ foi a maior entre todas as outras. Em seguida vem a 
média referente á Questão 8, relacionada infra-estrutura e assistência técnica (média 1,41) e pelo reconhecimento como referência na comercialização (Questão 6), com média 1,31. Esses resultados mostram que tanto comércio, como produção de flores e plantas ornamentais, são competências que, dentre outras, se destacam para os profissionais dos agronegócios, segundo percepção apresentada pelos produtores entrevistados.

Quadro 6.3 Questões relacionadas à investigação dos fatores associados à localidade

1. O governo local é atuante no sentido de promover o desenvolvimento dos agronegócios de flores no município e/ou região

2. A cooperativa/associação é atuante no sentido de promover o desenvolvimento dos agronegócios de flores e plantas para seus associados

3. Não conheço nenhum tipo de política pública relacionada à promoção do desenvolvimento dos agronegócios de flores e plantas nesta região

4. O município (região) onde desenvolvo meus negócios apresenta as melhores condições para o desempenho da floricultura, se comparado a outros municípios e/ou regiões do Brasil.

5. Esta Região onde estou sediado é reconhecida especificamente pela produção de flores e plantas.

6. Esta Região onde estou sediado é reconhecida pela comercialização de flores

7. Esta Região onde estou sediado é reconhecida pelo cultivo protegido

8. Uma das vantagens em estar localizado neste município e/ou região é sua infra-estrutura e assistência técnica

9. Uma das vantagens em estar localizado neste município ou região é que facilita a contratação de mão-de-obra especializada no cultivo de flores e treinamento.

10. Uma das vantagens em estar localizado neste município e/ou região é que me proporciona a aproximação com outros produtores de flores, o que ajuda na solução de problemas relacionados ao meu negócio (produção e venda)

11. Uma das desvantagens em estar localizado neste município (região) que existe uma saturação das possibilidades de produção local, pois atrai produtores de outras regiões.

12. Uma das desvantagens em estar localizado neste município e/ou região que a localidade está sofrendo com a atração de novos produtores, que está deteriorando as fortes relações entre os produtores locais mais antigos.

13. Uma das desvantagens em estar localizado neste município elou região é que a alta concentração de produtores e de outros agentes de negócios aqui, pressiona os custos de produção para cima.

Fonte: o autor

A análise estratificada por localidade é apresentada no Gráfico 6.9. Neste gráfico é possível observar inversão da percepção na Questão 9, além disto, existe expressiva diferença nos valores médios nas questões 2, 3, 4, 7 e 13.

A diferença observada entre os valores médios das respostas atribuídas ao papel das cooperativas e associações de produtores rurais na promoção dos 
agronegócios locais (Questão 2), reflete o papel maior exercido pela estrutura cooperativa de Holambra em relação à localidade de Mogi das Cruzes. Essa diferença estrutural é observada pelo número de cooperativas de produção e comercialização existente nas localidades, sendo três na primeira localidade e apenas uma na segunda.
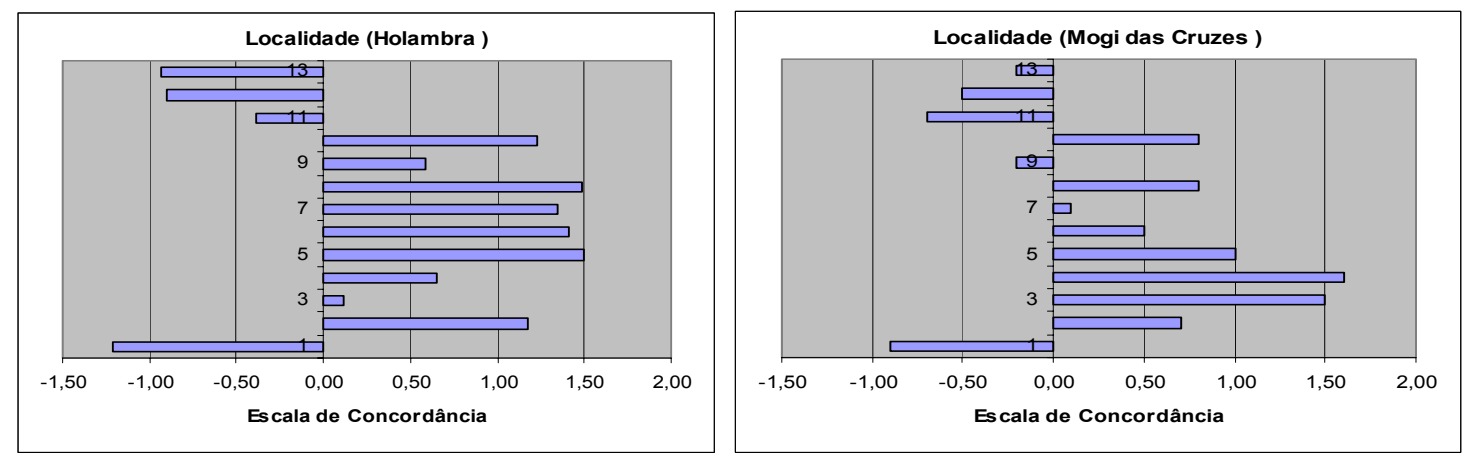

Gráfico 6.9 - Média dos valores de concordância com as questões relativas à percepção do papel da localidade na construção das vantagens competitivas dos negócios de flores e plantas ornamentais das localidades de Holambra e Mogi das Cruzes - analise separada (Fonte: o autor)

Na localidade de Mogi das Cruzes, observa-se para a Questão 3 uma concordância média muito superior à observada para a localidade de Holambra (1,50 e 0,11, respectivamente), mostrando que há um maior desconhecimento por parte dos produtores ali sediados, quanto ao conhecimento das políticas públicas para o setor de flores e plantas ornamentais. Outrossim, observa-se por parte dos produtores de Mogi das Cruzes um vínculo maior com a localidade no sentido de a considerarem como melhor região para o desenvolvimento de seus negócios, cuja média de concordância foi de 1,60. Já para os produtores de Holambra esta percepção é mais tênue, com média de 0,65, representada na Questão 4.

É curioso observar que apesar da localidade de Mogi das Cruzes ter apresentado valores médios mais significativos para a Questão 4, esta mesma localidade apresentou valores de respostas menores para as questões 8 e 10, quando comparadas às médias apresentadas na localidade de Holambra. Isso sinaliza que as melhores condições relativas à Questão 4, não estão associadas às questões de infra-estrutura e com a proximidade com outros 
produtores. Além disto, a percepção de discordância, associada à Questão 9, também não permite associar às melhores condições da localidade no que concerne à disponibilidade de mão-de-obra especializada.

\subsubsection{Bloco 4 - Cooperativismo e Associativismo}

A construção desse bloco, teve como objetivo investigar o papel das entidades cooperativas e associativistas, como elementos estratégicos para a formação da base competitiva dos agronegócios das localidades estudadas.

Foram apresentadas as questões do Quadro 6.4, utilizando-se a mesma escala de Likert, utilizada nos blocos anteriores

Quadro 6.4 Questões relacionadas à investigação dos fatores relacionados ao o papel das entidades cooperativas e associativistas

1. O numero de espécies que o Sr. pode cultivar é definida pela cooperativa ou associação a que pertence

2. A maior parte (ou a totalidade) de sua produção vai para a cooperativa ou associação de produtores que participo

3. A cooperativa distribui e comercializa seus produtos de maneira mais eficiente do que se não estivesse me associado a ela

4. A associação a que pertence, apesar de não atuar diretamente na comercialização dos seus produtos, auxilia bastante nessa etapa

5. A cooperativa estabelece os preços de venda e as condições para recebimento das vendas de seus produtos

6. A cooperativa estreita os laços de relacionamento e confiança entre os produtores

7. A cooperativa promove com freqüência o treinamento/ capacitação dos produtores e/ou seus empregados

8. A cooperativa divulga com freqüência os agentes e as linhas de financiamentos disponíveis.

9. O cooperativismo elou associativismo é fundamental para o bom desempenho de meus negócios (flores e plantas) nesta região

Fonte: o autor

A importância da estrutura e das organizações cooperativas ou associativistas na construção da base competitiva da localidade (Questão 9) foi a percepção de concordância mais expressiva deste bloco, conforme ilustra o Gráfico 6.10. O valor médio de concordância para esta questão mostrou-se elevado $(1,72)$, muito próximo à concordância plena.

A percepção de concordância apresentada nas questões 2, 3 e 6, cujas médias são respectivamente 1,17, 1,27 e 0,99, revelam a concordância parcial com 
estas questões. Desta forma, há indícios de que nestas localidades a maior parte da produção seja escoada via cooperativa/ associação de produtores (Questão 2). Além disto, existe uma percepção dos produtores que este meio de distribuição/ comercialização é o mais eficiente (Questão 3) e que a cooperativa estreita os laços de relacionamento e confiança entre os produtores (Questão 6).

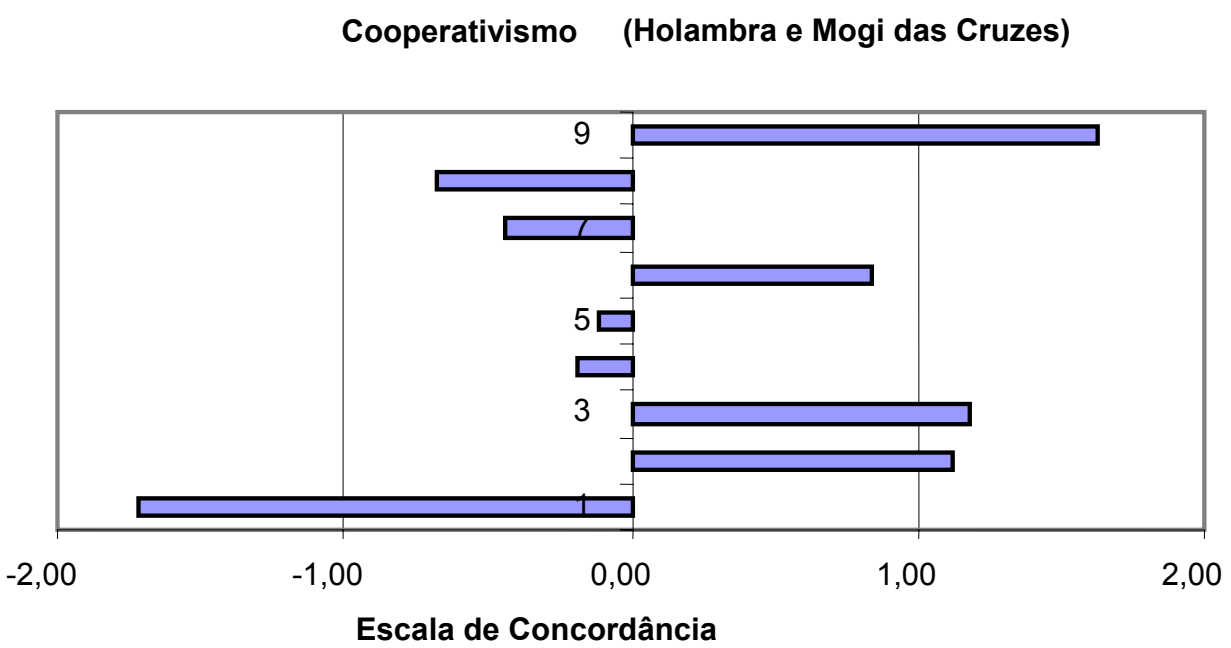

Gráfico 6.10 - Média dos valores de concordância com as questões relativas à percepção do papel das entidades associativistas e cooperativistas na construção das vantagens competitivas dos negócios de flores e plantas ornamentais das localidades estudadas (Fonte: o autor)

Com relação aos níveis de discordância, a Questão 1, apresentou uma média próximo ao máximo $(-1,94)$, mostrando que a cooperativa não interfere nas opções de produção de seus cooperados, cabendo ao produtor este tipo de decisão, conforme suas capacidades.

A Questão 2 mostra que os produtores fornecerem grande parte de sua produção as cooperativas, conforme já salientado anteriormente.

A Questão 8 mostra discordância, sugerindo que nas duas localidades as cooperativas não desempenham um efetivo papel em levar as informações de caráter financeiro (linhas de crédito e financiamento) aos seus cooperados.

Mesmo apresentando diferenças expressivas com relação às Questões 2 e 5, onde houve divergência de percepção de concordância e discordância (ver Gráfico 6.10), em termos gerais a análise estratificada por localidade 
mostra que as duas localidades apresentaram um mesmo comportamento com relação a média de concordância com as questões deste bloco.

No Gráfico 6.11, é possível observar que no caso da Questão 5, estes valores estão muito próximos a neutralidade (zero), no entanto na Questão 2, a localidade de Holambra manifestou uma tendência para a concordância, com média igual a 1,35, enquanto a localidade de Mogi das Cruzes, apontou para uma tênue percepção de discordância, com média igual a $-0,70$. Esse resultado é condizente com o apresentado anteriormente, no qual a maioria dos os produtores de Holambra destinam a grande parte ou totalidade de sua produção, à cooperativa.

A diferença observada para a questão 3 , foi somente com relação à magnitude da média das respostas, sendo muito inferior em Mogi das Cruzes do que a apresentada pelos produtores da localidade de Holambra.

Essa diferença observada entre o comportamento das duas localidades está relacionada, provavelmente a menor capacidade comercial da cooperativa da localidade de Mogi das Cruzes (SPFlores), que por ocasião desta pesquisa, passava por um processo profundo de re-estruturação estrutural e de gestão.

Cooperativismo (Holambra)

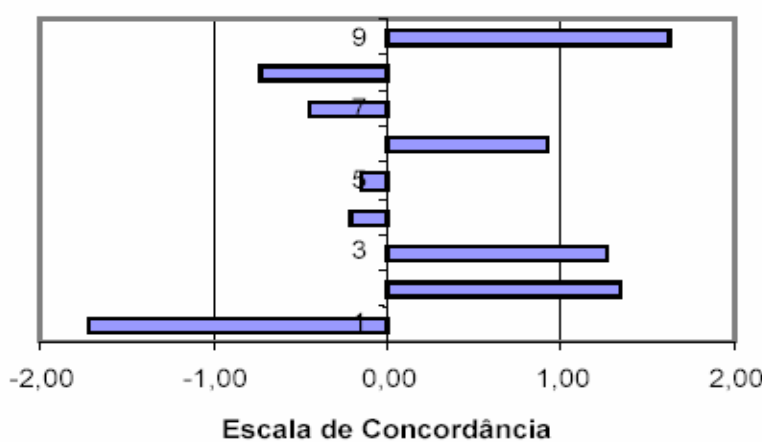

Cooperativismo (Mogi das Cruzes)

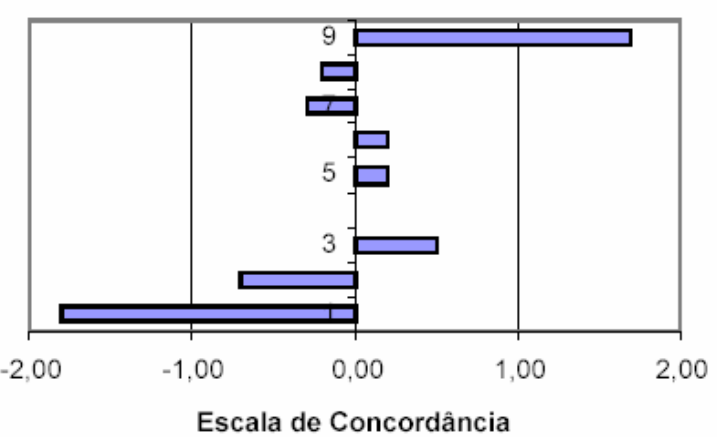

Gráfico 6.11 - Média dos valores de concordância com as questões relativas à percepção do papel das entidades associativistas e cooperativistas na construção das vantagens competitivas dos negócios de flores e plantas ornamentais em cada uma das localidades estudadas (Fonte: o autor) 


\subsection{REFINAMENTO DA ANÁLISE DOS RESULTADOS}

Uma vez apresentados a estatística descritivas dos resultados na seção 6.2, passa-se a aplicar análises estatísticas para um refinamento da análise dos resultados. Utilizou-se apenas os resultados obtidos nas questões estruturadas com base na percepção de concordância/discordância, utilizando a escala Likert já descrita anteriormente.

As análises estatísticas foram feitas segundo descrito no Capítulo 3, utilizando as seguintes técnicas: análise discriminante e análise fatorial e de agrupamentos.

A analise fatorial associada à análise de agrupamentos (cluster) buscou identificar os principais fatores comuns (variáveis) determinantes na formação de grupos entre os produtores entrevistados e separadamente. Utilizou-se também a análise discriminante, para visando mensurar os respondentes que apresentaram percepções idênticas ou distintas.

\subsubsection{Análise Discriminante}

A análise discriminante consiste em identificar as variáveis que melhor discriminam grupos previamente fixados, em função do objeto da pesquisa. Neste estudo as variáveis consideradas foram todas as questões estruturadas com base na percepção de concordância/discordância, na escala de Likert, em função dos seguintes grupos: localidade (Holambra e Mogi das Cruzes), ano de inicio na floricultura e caráter étnico.

Dos três grupos considerados, somente o relacionado à etnia mostrou resultado significativo, com índices de correlação da classificação adotada, superior a 90\%, conforme pode ser observado na Tabela 6.1. Esse resultado mostra que há uma forte influencia do fator étnico no comportamento de resposta dos entrevistados, ou seja, a percepção apresentada pelo respondente está muito associada à sua origem étnica/ascendência, independentemente da localização de sua Unidade Agrícola de Produção. 
Tabela 6.1. Classificação dos resultados da análise discriminante em função a etnia nas duas localidades estudadas

\begin{tabular}{|c|c|c|c|c|c|c|c|}
\hline \multicolumn{8}{|c|}{ Classification Results $\mathrm{s}^{\mathrm{b}, \mathrm{c}}$} \\
\hline & & \multirow[b]{2}{*}{ origem } & \multicolumn{4}{|c|}{ Predicted Group Membership } & \multirow[b]{2}{*}{ Total } \\
\hline & & & 1.00 & 2.00 & 3.00 & 4.00 & \\
\hline \multirow[t]{10}{*}{ Original } & Count & 1.00 & 38 & 0 & 2 & 0 & 40 \\
\hline & & 2.00 & 0 & 17 & 0 & 0 & 17 \\
\hline & & 3.00 & 1 & 1 & 29 & 0 & 31 \\
\hline & & 4.00 & 0 & 0 & 0 & 1 & 1 \\
\hline & & Ungrouped cases & 0 & 0 & 1 & 0 & 1 \\
\hline & $\%$ & 1.00 & 95.0 & .0 & 5.0 & .0 & 100.0 \\
\hline & & 2.00 & .0 & 100.0 & .0 & .0 & 100.0 \\
\hline & & 3.00 & 3.2 & 3.2 & 93.5 & .0 & 100.0 \\
\hline & & 4.00 & .0 & .0 & .0 & 100.0 & 100.0 \\
\hline & & Ungrouped cases & .0 & .0 & 100.0 & .0 & 100.0 \\
\hline \multirow[t]{8}{*}{ Cross-validated $^{a}$} & Count & 1.00 & 31 & 3 & 5 & 1 & 40 \\
\hline & & 2.00 & 4 & 11 & 2 & 0 & 17 \\
\hline & & 3.00 & 7 & 3 & 20 & 1 & 31 \\
\hline & & 4.00 & 0 & 1 & 0 & 0 & 1 \\
\hline & $\%$ & 1.00 & 77.5 & 7.5 & 12.5 & 2.5 & 100.0 \\
\hline & & 2.00 & 23.5 & 64.7 & 11.8 & .0 & 100.0 \\
\hline & & 3.00 & 22.6 & 9.7 & 64.5 & 3.2 & 100.0 \\
\hline & & 4.00 & .0 & 100.0 & .0 & .0 & 100.0 \\
\hline \multicolumn{8}{|c|}{$\begin{array}{l}\text { a. Cross validation is done only for those cases in the analysis. In cross validation, each case is classified by the } \\
\text { functions derived from all cases other than that case. }\end{array}$} \\
\hline \multicolumn{8}{|c|}{ b. $95.5 \%$ of original grouped cases correctly classified. } \\
\hline \multicolumn{8}{|c|}{ c. $69.7 \%$ of cross-validated grouped cases correctly classified. } \\
\hline
\end{tabular}

Nota: Classificação das origens apresentadas nesta tabela: 1 (holandês ou descendente); Fonte: o autor 2 (japonês ou descendente), 3(brasileiro sem qualquer vinculo com as etnias anteriores) e 4 (origem português); Ungrouped cases (sem identificação no questionário)

Nesta análise foram considerados todas as etnias identificadas no questionário, buscando maior precisão no fator étnico estudado. Na Figura 6.1, onde está representado graficamente a distribuição das respostas, curiosamente é possível observar um que o produtor de origem portuguesa apresenta o mesmo comportamento dos produtores de origem japonesa (na Figura 6.1, seu ponto está sobrescrito pelo ponto representativo da marca do centróide da Origem 4). Esse é um fato curioso, ainda mais e considerarmos que esse produtor está sediado no município paulista de Cotia, pertencente a localidade de Holambra, que no entanto, conta com uma presença de produtores rurais de origem japonesa muito intensa.

Com relação ao único produtor que não identificou sua origem, por esse mesmo gráfico, percebe-se que apresenta o mesmo comportamento dos brasileiros (Origem 3). 


\section{Canonical Discriminant Functions}

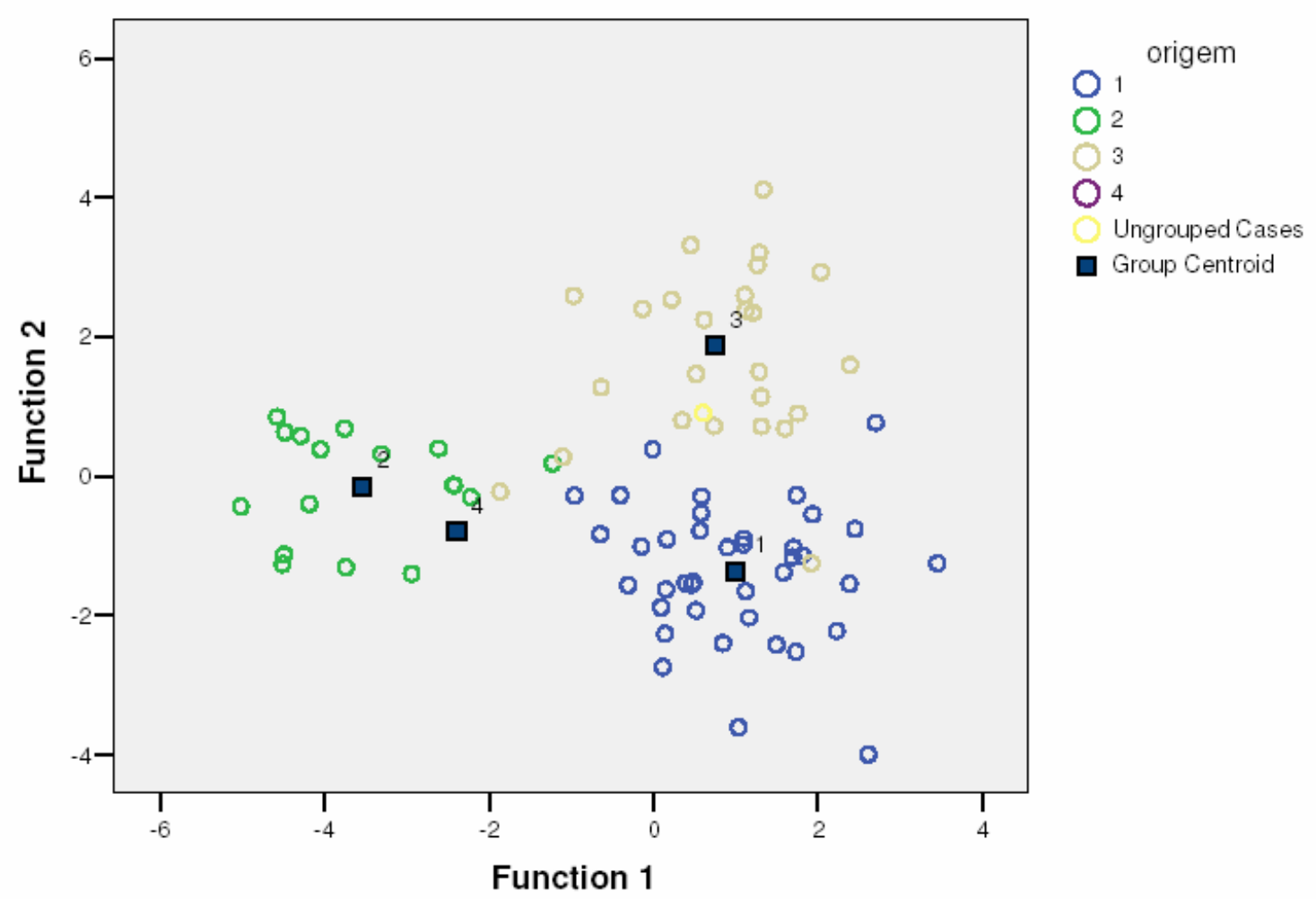

Figura 6.1. Representação gráfica do comportamento de resposta dos questionários em função do caráter étnico dos produtores

Nota: Classificação das origens apresentadas nesta Figura: 1 (holandês ou descendente);

2 (japonês ou descendente), 3(brasileiro sem qualquer vinculo com as etnias anteriores) e 4 (origem português); Ungrouped cases (sem identificação no questionário)

\subsubsection{Análise Fatorial e de Agrupamentos}

Segundo Costa (2006) a análise fatorial tem como principal aplicação reduzir o numero de dados a serem analisados. Esse tipo de análise estatística é, portanto, aplicável no presente estudo, visando à redução do número de variáveis de resposta, uma vez que o volume gerado pelo instrumento de pesquisa utilizado era extenso.

No entanto, a analise fatorial em muitos casos não permite que se tenha uma adequação plena de todos os fatores com o objeto da pesquisa. Esses fatores são formados exclusivamente pelo resultado do tratamento estatístico aplicado à amostra e, por isso, não se pode esperar a plena adequação de todos os fatores 
gerados ao objeto alvo do estudo realizado. Nesse sentido, muitos autores discutem os procedimentos estatísticos necessários para o refino dos resultados obtidos por esse tipo de análise, sem no entanto, terem encontrado um consenso sobre o assunto (COSTA, 2006 FLOYD, F. J.; WIDAMAN,198 PASQUALI, 1999; GÜNTHER, 1999;CLARK; WATSON, 1995).

A análise fatorial resultou na consolidação de 15 fatores e a analise de cluster resultou em 11 grupos. Os fatores de número 1, 4, 6, 9, 13, 14 e 15 mostraram significativo no contexto estatístico (ver Tabela 6.2), no entanto, os fatores 14 e 15 não trouxeram nenhum resultado em termos do contexto estudado e portanto, não foram aqui considerados. O Quadro 6.5 mostra as questões que compõe cada fator, conforme agrupamento obtido na análise fatorial.

A análise dos resultados será apresentada a seguir, em função da relação dos grupos com cada um dos fatores considerados na Tabela 6.2

Tabela 6.2. Relação entre os grupos e fatores relacionados às percepções dos entrevistados

\begin{tabular}{|c|c|c|c|c|c|c|c|c|}
\hline Grupo & Medidas & FATOR 1 & FATOR 4 & FATOR 6 & FATOR 9 & FATOR 13 & FATOR 14 & FATOR 15 \\
\hline \multirow[t]{2}{*}{1} & Média & $-0,60$ & 0,19 & 0,50 & 0,21 & 0,53 & 0,37 & 0,57 \\
\hline & $\mathrm{N}^{\circ}$ produtores & 6 & 6 & 6 & 6 & 6 & 6 & 6 \\
\hline \multirow[t]{2}{*}{2} & Média & $-0,82$ & 0,81 & 0,43 & $-0,53$ & $-1,93$ & 1,26 & 0,01 \\
\hline & $\mathrm{N}^{\circ}$ produtores & 3 & 3 & 3 & 3 & 3 & 3 & 3 \\
\hline \multirow[t]{2}{*}{3} & Média & $-0,06$ & $-0,98$ & $-0,02$ & $-0,16$ & $-0,36$ & $-0,02$ & 0,31 \\
\hline & $\mathrm{N}^{\circ}$ produtores & 9 & 9 & 9 & 9 & 9 & 9 & 9 \\
\hline \multirow[t]{2}{*}{4} & Média & $-0,77$ & 0,44 & $-0,89$ & 0,09 & 0,24 & $-0,32$ & 0,48 \\
\hline & $\mathrm{N}^{\circ}$ produtores & 9 & 9 & 9 & 9 & 9 & 9 & 9 \\
\hline \multirow[t]{2}{*}{5} & Média & 0,05 & 0,06 & 0,44 & 1,53 & $-0,05$ & $-0,77$ & $-0,77$ \\
\hline & $\mathrm{N}^{\circ}$ produtores & 4 & 4 & 4 & 4 & 4 & 4 & 4 \\
\hline \multirow[t]{2}{*}{6} & Média & 1,56 & 0,33 & 0,71 & $-0,02$ & $-0,24$ & $-0,10$ & 0,34 \\
\hline & $\mathrm{N}^{\circ}$ produtores & 12 & 12 & 12 & 12 & 12 & 12 & 12 \\
\hline \multirow[t]{2}{*}{7} & Média & $-0,15$ & 0,40 & 0,19 & 0,36 & 0,23 & 0,10 & 0,20 \\
\hline & $\mathrm{N}^{\circ}$ produtores & 14 & 14 & 14 & 14 & 14 & 14 & 14 \\
\hline \multirow[t]{2}{*}{8} & Média & $-0,28$ & 0,36 & $-0,89$ & 1,00 & $-1,20$ & $-0,30$ & $-0,84$ \\
\hline & $\mathrm{N}^{\circ}$ produtores & 8 & 8 & 8 & 8 & 8 & 8 & 8 \\
\hline \multirow[t]{2}{*}{9} & Média & $-0,30$ & 0,04 & 0,57 & 0,10 & 0,96 & 0,48 & 0,35 \\
\hline & $\mathrm{N}^{\circ}$ produtores & 9 & 9 & 9 & 9 & 9 & 9 & 9 \\
\hline \multirow[t]{2}{*}{10} & Média & $-0,16$ & $-3,00$ & 0,12 & $-0,45$ & 0,25 & $-0,64$ & $-0,23$ \\
\hline & $\mathrm{N}^{\circ}$ produtores & 4 & 4 & 4 & 4 & 4 & 4 & 4 \\
\hline \multirow[t]{2}{*}{11} & Média & 0,19 & 0,48 & $-0,63$ & $-1,43$ & 0,29 & 0,05 & $-0,82$ \\
\hline & $\mathrm{N}^{\circ}$ produtores & 12 & 12 & 12 & 12 & 12 & 12 & 12 \\
\hline
\end{tabular}

Fonte: o autor 


\section{Quadro 6.5. Composição dos Fatores em função das questões consideradas na análise} fatorial

\section{FATOR 1}

Freqüência de ações de cooperação/parceria com Clientes situados no Brasil

Freqüência de ações de cooperação /parceria com Clientes situados no Exterior

Freqüência de ações de cooperação /parceria com SEBRAE

Freqüência de ações de cooperação/parceria com SENAR

Freqüência de ações de cooperação /parceria com Entidades de pesquisa (IAC, EMBRAPA, etc.)

\section{FATOR 2}

A cooperativa/associação é atuante no sentido de promover o desenvolvimento dos agronegócios de flores e plantas para seus associados

A maior parte (ou a totalidade) de sua produção vai para a cooperativa ou associação de produtores que participo

A cooperativa distribui e comercializa seus produtos de maneira mais eficiente do que se não estivesse me associando a ela

O cooperativismo e/ou associativismo é fundamental para o bom desempenho de meus negócios (flores e plantas) nesta região

A maior parte (ou a totalidade) de sua produção é feita em cultivo protegido

O numero de espécies que o Sr. pode cultivar é definida pelo em função de sua capacidade de produção associado a demanda do mercado

O Sr utiliza com freqüência a Internet para obter informações de mercado

\section{FATOR 3}

A maioria das ações de parcerias e/ou cooperação com outros produtores, clientes, fornecedores ou outras empresas da floricultura que estabeleci surgiu através de laços familiares".

A maioria das ações de que estabeleci parcerias e/ou cooperação com outros produtores, clientes, fornecedores ou outras empresas da floricultura surgiu pelo incentivo/intermediação do Sindicato Patronal, e/ou Sindicato de trabalhadores; entidades como SEBRAE, SENAR, associação comercial local; etc"

Uma das desvantagens em estar localizado neste município (região) é que existe uma saturação das possibilidades de produção local, pois atrai produtores de outras regiões.

A maior parte (ou a totalidade) de sua produção vai para a cooperativa ou associação de produtores que participo

\section{FATOR 4}

Esta Região onde estou sediado é reconhecida especificamente pela produção de flores e plantas.

Esta Região onde estou sediado é reconhecida pela comercialização de flores.

Esta Região onde estou sediado é reconhecida pelo cultivo protegido

\section{FATOR 5}

O governo local é atuante no sentido de promover o desenvolvimento dos agronegócios de flores no município e/ou região

A cooperativa/associação promove com freqüência o treinamento/ capacitação dos produtores e/ou seus empregados

O Sr recebe freqüentes informações por parte da(s) cooperativa(s), SEBRAE, SENAR, associação comercial, associação de produtores da qual é associado, sobre linhas de financiamento de meus negócios e formas de gestão

\section{FATOR 6}

A maioria das ações de parcerias e/ou cooperação com outros produtores, clientes, fornecedores ou outras empresas da floricultura que estabeleci surgiu consolidação das relações comerciais, com o tempo"

A maioria das ações de parcerias e/ou cooperação que estabeleci com outros produtores, clientes, fornecedores ou outras empresas da floricultura surgiu pelo incentivo/intermediação da cooperativa e/ou associação de produtores a qual sou filiado

\section{FATOR 7}

Uma das vantagens em estar localizado neste município e/ou região é o acesso à matéria-prima, infraestrutura e assistência técnica

Uma das vantagens em estar localizado neste município e/ou região é que facilita a contratação de mão-deobra especializada no cultivo de flores e treinamento.

Uma das desvantagens em estar localizado neste município e/ou região que existe uma saturação das possibilidades de produção local, pois atrai produtores de outras regiões. 
(Quadro 6.5 - Continuação)

\section{FATOR 8}

Uma das desvantagens em estar localizado neste município e/ou região é que existe uma saturação das possibilidades de produção local, pois atrai produtores de outras regiões.

Uma das desvantagens em estar localizado neste município e/ou região é que a localidade está sofrendo com a atração de novos produtores, que está deteriorando as fortes relações entre os produtores locais mais antigos.

Uma das desvantagens em estar localizado neste município e/ou região é que a alta concentração de produtores e de outros agentes de negócios aqui, pressiona os custos de produção para cima.

\section{FATOR 9}

Freqüência de ações de cooperação e/ou parcerias com outros produtores rurais que cultivam as mesmas espécies que são cultivadas em sua propriedade

Freqüência de ações de cooperação e/ou parcerias com produtores rurais que cultivam as outras espécies que são cultivadas em sua propriedade

\section{FATOR 10}

A maioria das ações de parcerias e/ou cooperação com outros produtores, clientes, fornecedores ou outras empresas da floricultura que estabeleci surgiu independentemente de laços culturais e/ou de ascendência estrangeira.

Estabeleci tais ações por que sei da importância delas para o fortalecimento da estrutura de produção e/ou comercialização da qual dependo.."

O numero de espécies que o Sr. pode cultivar é definida pela cooperativa ou associação a que pertence

\section{FATOR 11}

Freqüência de ações de cooperação e/ou parcerias com Fornecedores situados no Exterior Freqüência de ações de cooperação e/ou parcerias com Clientes situados no Exterior

O município (região) onde desenvolvo meus negócios apresenta as melhores condições para o desempenho da floricultura, se comparado à outros municípios e/ou regiões do Brasil.

Falta de clareza das normas de financiamento dos agentes, burocracia e excesso de garantias dificultam o acesso aos recursos financeiros

\section{FATOR 12}

Não conheço nenhum tipo de política pública relacionada a promoção do desenvolvimento dos agronegócios de flores e plantas nesta região

A associação a que pertence apesar de não atuar diretamente na comercialização dos seus produtos, auxilia bastante nessa etapa

\section{FATOR 13}

Em geral, os seus treinamentos são realizados com capital da própria empresa

\section{FATOR 14}

O Sr estimula o contato de seus empregados com empregados de outras empresas da região

\section{FATOR 15}

A Internet é uma importante ferramenta para divulgação de meus produtos e para venda direta ao consumidor final

Fonte: o autor 


\subsubsection{Fator 1}

A análise da Tabela 6.2. mostra que apenas o Grupo 6 mostrou uma média positiva elevada com relação às demais. Isso significa que os produtores deste grupo, apresentam maiores freqüências de ações conjuntas com seus clientes, entidades de apoio e pesquisa, quando comparado a amostra pesquisada. Esse grupo é formado exclusivamente por produtores sediados na localidade de Holambra, sendo que somente um é holandês ou tem ascendência holandesa e os demais não tem qualquer vinculo de ascendência japonesa ou holandesa. Uma característica marcante desse grupo é que cinco de seus componentes relataram que o convívio com outros produtores e a experiência como empregado, foram as origens principais do conhecimento necessário para o desenvolvimento de seus negócios.

As questões componentes desse fator têm como principal característica a disponibilidade para o compartilhamento de informações e a observação. Isso, em parte, pode explicar a maior intensidade de parcerias apresentadas por esse grupo de produtores e ainda mais, com agentes cujas parcerias com os demais entrevistados, foi fraca ou inexistente.

\subsubsection{Fator 4}

A maioria dos Grupos se relacionara de maneira positiva a esse fator, exceção feita aos Grupos 3 e 10.

Destaca-se que o Grupo 10 foi aquele que apresentou apresentou um comportamento muito distinto com relação aos demais. Esse grupo se mostrou enfaticamente discordante, alcançando o máximo valor médio atribuído por esta análise fatorial (que varia de -3 a 3 ). Isso significa dizer que se trata de um grupo que congrega produtores com uma percepção muito destoante dos demais produtores frente ao reconhecimento pelas competências da comercialização, produção ou pelo cultivo protegido de flores e plantas. Esse grupo é formado exclusivamente por produtores sediados nos municípios paulistas de Itupeva, Várzea Grande Paulista e Cotia e no município mineiro de Andradas. 
Com relação ao Grupo 3, observa-se também uma percepção de discordância com relação as questões relacionadas ao Fator 4, porém em menor intensidade. Esse Grupo é formado por nove produtores rurais, sendo três deles relacionados à localidade de Mogi das Cruzes e os demais à localidade de Holambra, sendo que dos seis produtores relacionados à localidade de Holambra, três são de origem japonesa e sediados no município de Ibiúna (SP).

Esse grupo demonstra que mesmo se relacionando intensamente com a localidade para o desenvolvimento de seus negócios, o fato de estarem sediados fora desta localidade, pode interferir na percepção sobre as competências que fazem a localidade ser reconhecida no cenário agrícola brasileiro. Além da formação étnica, a questão da localização da propriedade frente à localidade com a qual se relaciona, também pode ser um fator quer influencia na percepção dos entrevistados.

\subsubsection{Fator 6}

De maneira geral, a análise da Tabela 6.2 mostra que podem ser destacados dois grupos (4 e 8), que apresentaram a mesma média de discordância $(-0,89)$. Esses grupos são formados pelos produtores da localidade de Holambra e pertencem a uma das associações de agricultura familiar. O Grupo 4 é composto pelos produtores sediados em Arthur Nogueira e o Grupo 8 em Holambra.

O resultado encontrado para os dois Grupos, é concordante ao já discutido no Capitulo 5, bem como aos resultados descritos no item 6.2 deste capítulo. Para os agricultores pertencentes à essas duas associações, as ações de parceria não se relacionam a uma ação mais direta das entidades das quais participam (incluindo as cooperativa às quais são associados) e nem devido a consolidação das relações comerciais com o tempo.

A análise qualitativa dos dados, mostrou que essas ações estão mais relacionadas ao convívio gerado pelo próprio funcionamento dessas entidades.

A análise conjunta dos resultados quantitativos, quando associada aos resultados qualitativos, mostra a importância desse tipo de organização na 
promoção de ações conjuntas entre seus associados, sem a necessidade de que ações específicas sejam preparadas para isso.

\subsubsection{Fator 9}

As duas questões componentes desse Fator 9 relacionam-se ao fenômeno descrito por Porter (1998) e denominado co-opetição (Co-opetition), no qual foram identificados dois Grupos (5 e 11) dentre os produtores entrevistados, que apresentam uma maior intensidade de ações conjuntas entre si, sendo o primeiro com maior e o outro com menor intensidade respectivamente.

O Grupo 5 é pequeno, formado apenas por quatro produtores, sendo três sediados no município de Holambra e um no município de São Roque. O produtor sediado em São Roque é o único de ascendência japonesa desse Grupo. Neste Grupo, dois produtores responderam que desenvolvem parceria com seus colegas produtores com alta intensidade e dois manifestaram que as desenvolvem com média intensidade.

Com relação aos produtores do Grupo 11, este é formado por dez produtores localizados no município de Holambra e apenas um, localizado no município vizinho de Campinas. A maioria dos componentes deste grupo (oito) é de origem holandesa ou apresenta alguma ascendência Holandesa. Neste Grupo a freqüência de parcerias com os colegas está na faixa de baixo para nenhuma, explicando o baixo valor médio encontrado.

\subsubsection{Fator 13}

Dos três grupos relacionados a esse fator, somente um, o Grupo 9 é que traz significado de análise. Os demais grupos, apresentaram um resultado muito influenciado por uma quantidade expressiva de respostas relacionadas ao não conhecimento do assunto ou a falta de opinião sobre o mesmo, o que compromete uma análise mais concreta dos resultados. 
Com relação ao Grupo 9, o resultado por sua vez foi bastante consistente e revelou um caráter específico e bem destoante dos demais produtores entrevistados. Todos os componentes desse Grupo (a maioria pertence à localidade de Holambra) revelaram que os treinamentos realizados por eles são todos financiados com capital da própria empresa.

\subsection{TESTE DE HIPÓTESES}

Finalmente, esta seção encerra a análise dos resultados da pesquisa quantitativa, testando as hipóteses propostas na metodologia (Capítulo 3). Como as respostas eram fornecidas em categorias, utilizou-se o teste Qui-quadrado para análise da validade das hipóteses desta tese. Nas seções seguintes será discutida a validade das cinco hipóteses colocadas na pesquisa quantitativa.

\subsubsection{Validade da Hipótese 1}

Ho1: Não existe diferença na percepção da importância da identidade étnico-cultural como um fator determinante nas relações de cooperação para os grupos étnicos estudados

$H_{A} 1$ : Existe diferença na percepção da importância da identidade étnico-cultural como um fator determinante nas relações de cooperação para os grupos étnicos estudados.

O teste do Qui-quadrado para esta hipótese foi baseado na relação entre as diferentes etnias que compunham a amostra, agrupadas em: descendentes de holandeses ou holandeses; descendentes de japoneses ou japoneses e outras ascendências.

Ao grupo étnico, foi relacionada às respostas dadas pelos entrevistados à questão "A maioria das ações de parcerias e/ou cooperação que estabeleci com outros produtores, clientes, fornecedores ou outras empresas da floricultura, surgiu da comunidade étnica da qual sou descendente". 
Este teste mostrou os seguintes resultados: Qui-quadrado $=24,798$ e o valor de $P<0,001$. Desta forma, rejeita-se a hipótese $H_{0} 1$, ou seja, há indícios de que existam diferenças na percepção de que a etnia seja um fator determinante nas relações de cooperação, de acordo com o grupo étnico estudado.

As médias das respostas em função da origem étnica dos produtores estão representadas no Gráfico 6.12. Por esse gráfico é possível observar a nítida diferença entre as etnias consideradas. Enquanto os japoneses se mostraram mais influenciados por esse fator, os produtores de outras etnias (nesse Gráfico identificado com o número 3) mostram-se menos influenciados por esse fator. Os de etnia holandesa apresentam-se praticamente neutros.

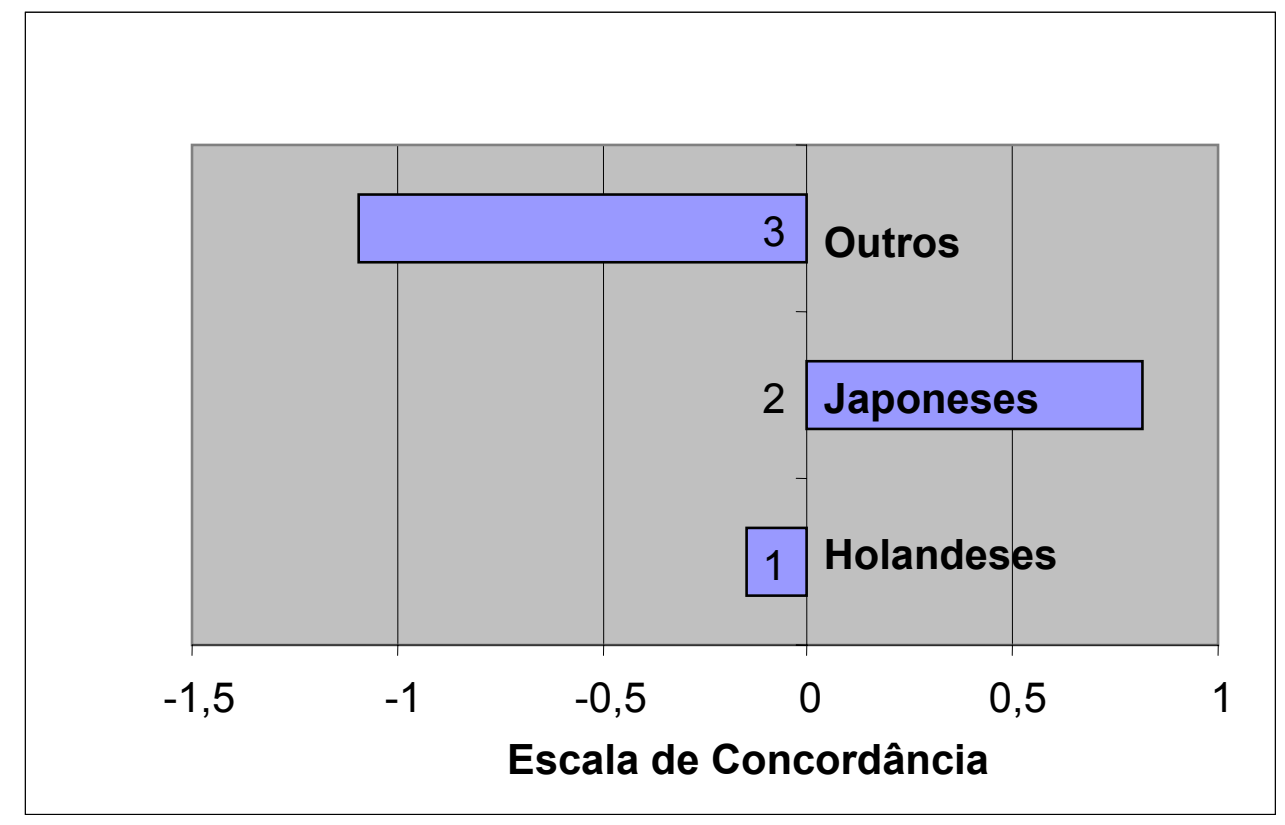

Gráfico 6.12 - Média dos valores de concordância com as questões relativas à percepção do papel da origem étnica no estabelecimento de ações conjuntas pelos produtores das duas localidades (Fonte: o autor)

É curioso observar que, para a etnia japonesa, houve diferenças expressivas nos valores médias estratificando por localidade, ou seja, os japoneses da localidade de Mogi das Cruzes (que refletem o cenário da Hipótese 1) obtiveram média de 1,5 (concordância quase plena), já os japoneses da localidade de Holambra obtiveram média $-0,17$ (discordância próxima da neutralidade), o que resultou na média geral da étnica japonesa de 0,8 (ver Gráfico 6.7). Portanto, existe um indício de que quanto maior a miscigenação na localidade, menor o impacto do fator étnico nas relações de cooperação. Esses resultados estão representados no Gráfico 6.12. 


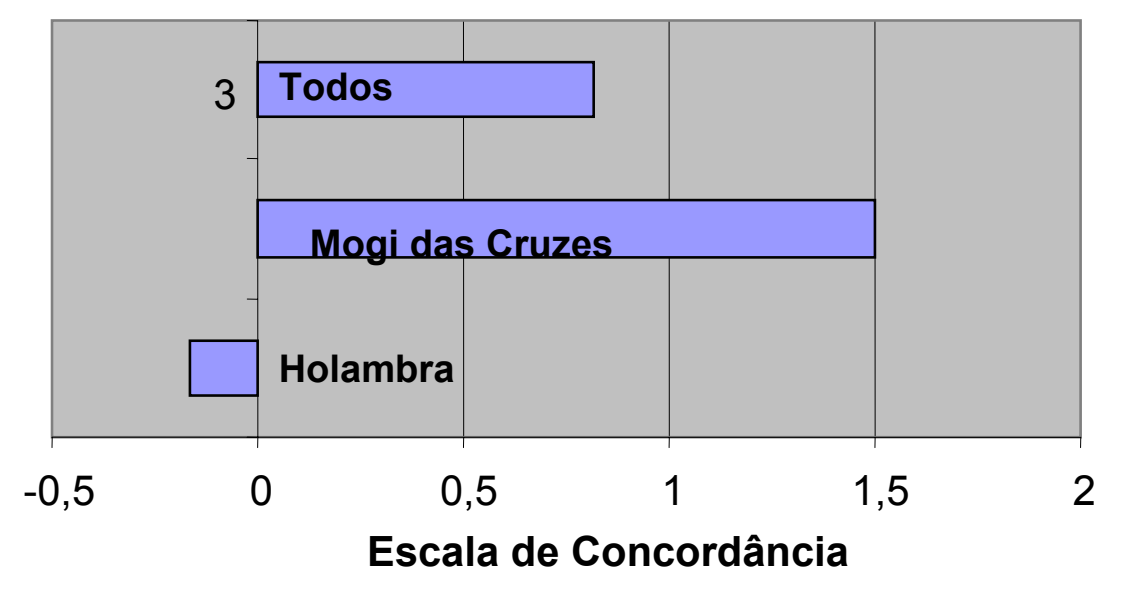

Gráfico 6.12 - Média dos valores de concordância com as questões relativas à percepção do papel da origem étnica no estabelecimento de ações conjuntas pelos produtores de origem japonesa (Fonte: 0 autor)

\subsubsection{Validade da Hipótese 2}

Ho2: Não existe diferença na percepção da importância das cooperativas / associações como um fator determinante para o sucesso dos negócios, considerando-se as localidades.

$H_{A}$ 2: Existe diferença na percepção da importância das cooperativas / associações seja um fator determinante para o sucesso dos negócios, considerando-se as localidades.

O teste do Qui-quadrado para esta hipótese foi baseado na relação entre as respostas da percepção dos entrevistados de cada localidade sobre a importância das cooperativas para o sucesso de seus respectivos negócios. Este teste foi baseado na questão "A cooperativa/associação é atuante no sentido de promover o desenvolvimento dos agronegócios de flores e plantas para seus associados" e mostrou os seguintes resultados: Qui-quadrado $=0,139$ e o valor de $P=0,933$.

Esse resultado, não significativo ao nível de $5 \%$ de probabilidade, mostra que a Hipótese $\mathrm{H}_{0} 2$ deve ser aceita, ou seja, não há indícios de que essa percepção 
seja alterada de acordo com a localidade. Portanto, em ambas as localidades houve concordância de que a cooperativa é um fator determinante para o sucesso dos negócios. Essa importância pode ser observada na média das respostas do nível de concordância obtido em cada uma das localidades com relação a essa mesma questão: 1,63 para a localidade de Holambra e de 1,70 para a localidade de Mogi das Cruzes.

\subsubsection{Validade da Hipótese 3}

Ho3: Não existe diferença na percepção da importância do papel do poder público local para a construção das bases competitividade das empresas do agronegócio, considerando-se as localidades.

$H_{A}$ 3: Existe diferença na percepção da importância do poder público local para a construção das bases competitividade das empresas do agronegócio, considerando-se as localidades.

O teste do Qui-quadrado para esta hipótese foi baseado na relação entre as respostas da percepção dos entrevistados de cada localidade sobre a importância do poder público local para o sucesso de seus respectivos negócios. Este teste foi baseado na questão "O governo local é atuante no sentido de promover o desenvolvimento dos agronegócios de flores no município e/ou região" e mostrou os seguintes resultados: Qui-quadrado =0,2,755 e o valor de $\mathrm{P}=0,252$.

Esse resultado também não significativo ao nível de $5 \%$ de probabilidade, mostra que a Hipótese $\mathrm{H}_{0} 3$ deve ser aceita, ou seja, não há indícios de que essa percepção seja alterada de acordo com a localidade. Portanto, em ambas localidades houve concordância de que o poder público local não é atuante no sentido de promover o desenvolvimento das atividades da floricultura nas localidades estudadas. Essa percepção de ausência do poder público local pode ser observada na média das respostas do nível de concordância obtido em cada uma das localidades com relação a essa mesma questão: média -1,22 para a localidade de Holambra e de -0,90 para a localidade de Mogi das Cruzes. 


\subsubsection{Validade da Hipótese 4}

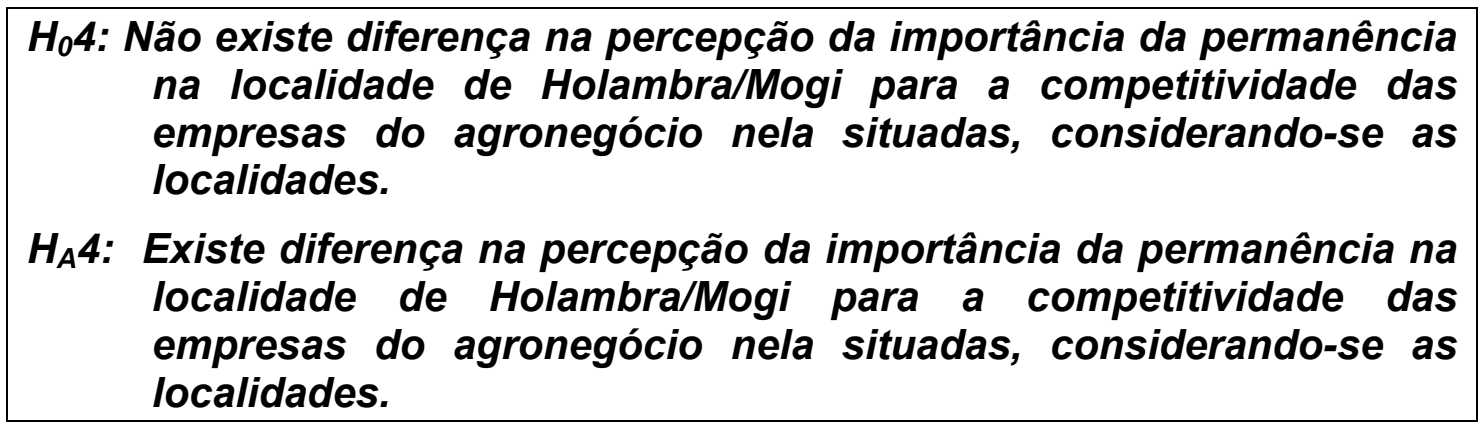

O teste do Qui-quadrado para esta hipótese foi baseado na relação entre as respostas da percepção dos entrevistados de cada localidade sobre a importância das cooperativas para o sucesso de seus respectivos negócios. Este teste foi baseado questão "O município (região) onde desenvolvo meus negócios apresenta as melhores condições para o desempenho da floricultura, se comparado à outros municípios e/ou regiões do Brasil" e mostrou os seguintes resultados: Qui-quadrado igual a 17,050 e o valor de $\mathrm{P}<0,001$.

Esse resultado significa que deve ser recusada a Hipótese $\mathrm{H}_{0} 4$ e que deve ser aceita a hipótese $\mathrm{H}_{\mathrm{A}} 4$. Isso posto, é possível observar que há indícios de que a percepção das condições apresentadas pela localidade, para o desempenho dos negócios, é diferente entre os produtores de Mogi das Cruzes e Holambra. Em ambas as localidades houve a concordância no sentido de que lá as condições para o desenvolvimento dos negócios são privilegiadas (média 0,65 para a localidade de Holambra e de 1,60 para a localidade de Mogi das Cruzes)

A significância ao nível de $1 \%$ para o intervalo de confiança apresentada neste teste mostra que as percepções médias entre as duas localidades são consideradas distintas. Isso significa dizer que a diferença na percepção dessas duas localidades é estatisticamente comprovada, ou seja, na localidade de Mogi das Cruzes, a percepção de que a região propícia melhores condições para o desenvolvimento dos negócios locais é mais acentuada do que para os produtores da localidade de Holambra. 


\subsection{ANÁLISE GLOBAL DOS RESULTADOS QUANTITATIVOS}

De maneira geral, os resultados qualitativos deste estudo apresentaram forte influencia da maior proporção de produtores relacionados à localidade de Holambra com relação aos produtores relacionados à localidade de Mogi das Cruzes. Essa influencia foi substancialmente mais forte com relação às percepções bem distintas das duas localidades sobre dois aspectos importantes: o papel da etnia no estabelecimento de ações conjuntas pelos produtores rurais e com relação ao papel das respectivas localidades na geração das vantagens competitivas locais.

Com relação à percepção das ações do poder público, as duas localidades mostraram um comportamento muito semelhante quando analisadas em separado: ambas destacaram uma atuação muito aquém das suas expectativas.

A influencia da maior proporção entre os produtores de Holambra e Mogi das Cruzes, também foi observada na formação dos Grupos na análise de cluster, onde predominaram os grupos compostos por produtores da Localidade de Holambra.

Além disso, a análise de cluster revelou que na localidade de Holambra, a percepção de das competências lá desenvolvidas é diferente entre os produtores sediados na própria localidade e aqueles que se encontram sediados fora dela mas que se utilizam das vantagens lá oferecidas para o desempenho de seus negócios.

Por fim, vale ser ressaltado que apesar de ter sido encontrado nos resultados aqui presentes, uma forte influencia da maioria de produtores relacionados à localidade de Holambra, nenhum dos aspectos anteriormente relacionados mostrou influenciar estatisticamente os testes das hipóteses realizadas no item anterior, mostrando que os resultados deles decorrentes não estão substancialmente influenciados por essa diferença proporcional de produtores entre as localidades. 


\section{CAPÍTULO 7. CONCLUSÕES E RECOMENDAÇÕES}

O presente estudo teve como tema central a concentração geográfica de empresas relacionadas a floricultura e o impacto gerado por esse tipo de arranjo na obtenção de vantagens competitivas da localidade e ao conjunto das empresas nela inseridas. Para tanto, foi proposto uma estrutura analítica para o estudo dessas localidades, baseado em duas formas de investigação empírica: estudo de caso e levantamento tipo survey.

A estratégia utilizada para o desenvolvimento empírico do trabalho, mostrouse adequada, na medida em que a dificuldade de acesso aos produtores rurais, implicou na elaboração de um questionário de rápida aplicação e o mais abrangente possível. Nesse sentido, o desenvolvimento da etapa qualitativa (entrevistas) permitiu ao mesmo tempo, coletar um número maior de informações a respeito do ambiente em que o estudo se desenvolvia e com isso adequar o questionário a ser aplicado para os produtores rurais.

Vale ressaltar que o fato de que muitos dos entrevistados, especificamente os diretores de associações ou cooperativas, são ou já foram produtores rurais de flores e/ou plantas ornamentais, ajudou muito na caracterização de um instrumento mais representativo do universo tão heterogêneo que é esse dos produtores rurais. Alguns aspectos investigados em ambas as pesquisas, mostram resultados muito congruentes, destacando assim a importância dos instrumentos e da estratégia utilizada.

De maneira geral, os resultados obtidos tanto na pesquisa qualitativa, quanto na quantitativa, mostram a pertinência da estrutura analítica proposta. Com relação à elaboração de um questionário mais específico e abrangente, voltado aos atores locais, que não os produtores rurais, os resultados relatados mostram que em muitos casos, as informações colhidas no estudo qualitativo ajudam a compreender melhor os resultados encontrados na parte quantitativa. Isso pode ser observado, especificamente, com relação aos resultados encontrados para as investigações relativas ao papel do Estado na promoção dos negócios locais; a importância das localidades na construção das externalidades positivas; a importância das localidades no desenvolvimento das competências locais; o desenvolvimento de 
ações conjuntas entre os atores e a importância das organizações cooperativas/associativas para o sucesso dos negócios locais.

A pesquisa qualitativa, além de possibilitar uma investigação mais abrangente, no que concerne a exploração de um número maior de fatores que não conseguiriam ser explorados diretamente com os produtores rurais, permitiu, dado seu caráter mais aberto, explorar alguns aspectos específicos que ajudaram muito no entendimento dos resultados observados na pesquisa quantitativa. Dentre esses aspecto podem ser destacados:

1. O desaparelhamento das estruturas governamentais de extensão rural que ajuda a caracterizar melhor os motivos da falta de ações específicas com os produtores locais. Isso por sua vez leva a explicar melhor a percepção geral da ausência do poder público na promoção dos agronegócios das localidades estudadas

2. O reconhecimento por parte de um diretor de associação de produtores que reclama por uma ação mais específica do poder público, ao mesmo tempo em que reconhece que essa ação pode ser em parte minimizada, caso haja uma ação mais específica dos produtores rurais nesse sentido.

3. Apesar dos resultados terem mostrado que ambas as localidades estudadas se vêem reconhecidas pela produção e comercialização de flores e plantas ornamentais, o estudo qualitativo foi importante para melhor esclarecer os motivos que geram a impossibilidade da caracterização da localidade mais importante para a floricultura paulista ou nacional. Os resultados qualitativos descreveram aspectos relacionados a especificidades de produção (como determinadas orquídeas na localidade de Mogi das Cruzes) ou a presença de externalidades (como a cultura cooperativista em Holambra ou as vantagens logísticas de Mogi das Cruzes) que impedem que tal caracterização seja feita.

4. Alguns elementos importantes para a compreensão da importância das localidades no desenvolvimento das competências locais, foram identificados no estudo qualitativo, como por exemplo à formação de uma das cooperativas de comercialização e produção em Holambra, com produtores cujo conhecimento havia sido adquirido no trabalho como empregado em outra propriedade (spillover). 
5. A explicação em duas entrevistas, das dificuldades de implantação plena dos princípios e valores cooperativistas, ajuda a explicar melhor a relação encontrada entre o reconhecimento da importância das organizações cooperativas para o sucesso dos negócios locais e as atividades de comercialização e distribuição que essas organizações estabelecem.

6. A parte qualitativa foi fundamental para melhor caracterizar o significado dos resultados encontrados, relacionados ao papel das associações e cooperativas nas ações conjuntas entre os produtores locais. O fato dos produtores terem manifestado, na pesquisa quantitativa, um papel importante dessas organizações para a promoção desse tipo de ações entre eles, não significa que essas tenham desenvolvido ações especificas para este fim. Tais ações foram desenvolvidas, em função da proximidade e confiança derivada das atividades relacionadas ao próprio funcionamento das associações ou cooperativas.

Quanto à identificação dos principais fatores indutores da inovação e da formação das competências coletivas das localidades (outro objetivo desse trabalho), a pesquisa qualitativa deixou bastante evidente que as conversas informais, a participação em feiras e eventos similares são os principais meios geradores das informações necessárias ao desenvolvimento das inovações e competências locais.

As duas localidades mostram-se relevantes na criação de externalidades positivas, principalmente aquelas relacionado a presença de mão-de-obra especializada, melhoria das condições para acesso a mercados consumidores. Especificamente para a localidade de Holambra, foi possível observar a presença significativa de empresas correlatas e de apoio e evidencias de transbordamentos específicos de conhecimento e habilidades que foram responsáveis pelo estabelecimento de novos negócios por parte de produtores que trabalhavam como empregados em outras propriedades e também pela estruturação de uma cooperativa de pequenos produtores de flores e plantas ornamentais. Com relação a esses fatores, foi possível a confirmação da Proposição 2 deste estudo.

Com relação ao instrumento utilizado pela pesquisa quantitativa, o mesmo foi fundamental para que se pudesse acessar os produtores de uma maneira rápida e eficiente, já que o acesso aos produtores rurais é sempre mais difícil do que o 
acesso aos outros atores do ambiente estudado. Além disso, a pesquisa quantitativa permitiu o tratamento estatístico dos resultados, (analise fatorial, cluster e teste das hipóteses) gerando um outro nível de análise comparativa dos resultados gerados por um instrumento que foi desenvolvido no desenrolar das atividades de pesquisa qualitativa.

Os resultados deste estudo mostram os principais fatores indutores para 0 estabelecimento de ações conjuntas nas relações verticais e horizontais do sistema agroindustrial estudado e os resultados conjuntos para as duas localidades mostram que a consolidação das relações comerciais com o tempo foi o principal fator indutor desse tipo de ação. Entretanto, a análise em separado dessas localidades, sugere que para os produtores da localidade de Mogi das Cruzes, a questão étnica assume papel relevante para esse tipo de ação enquanto que para a os produtores da localidade de Holambra, o papel das associações e/ou cooperativa de produtores, também se mostrou relevante para o estabelecimento desse tipo de ação conjunta pelos produtores rurais. No geral, a maior parte dessas ações de parceria foram estabelecidas para a participação em feiras e eventos similares, para atividades de capacitação de mão-de-obra (como dias de campo), acesso a novas tecnologias e para melhoria de processos.Esses resultados levaram a confirmação da Proposição 1.

Apesar de terem sido apesar de terem sido considerados como importantes nesse processo, a visão geral do grupo de entrevistados na pesquisa qualitativa, mostrou que os instrumentos estatais relacionados à extensão e capacitação rural (CATI e SENAR) tiveram suas ações consideradas insatisfatórias como agentes de geração de informações e inovação nas localidades. A análise dos dados qualitativos, mostrou que o poder público não atua com eficácia na indução de parcerias entre os atores locais, o que levou a não confirmação da Proposição 4 deste trabalho.

A analise fatorial e de clusters mostrou a existência de quinze fatores e onze grupos. Dentre os fatores, aqueles que mais se mostraram correlatos ao estudo desenvolvido, tiveram como caráter predominante as questões relativas as parcerias ou a localidade.

Com relação ao teste das hipóteses aqui levantadas, pôde ser observado que existe diferença na percepção entre as etnias, quanto ao papel desse fator no estabelecimento de parcerias entre os atores em ambas as localidades. Neste teste 
ficou sugerido também que as cooperativas são importantes para a construção das vantagens competitivas locais, contrariamente ao observado para o poder público. Este teste também mostrou que existem diferenças entre os produtores das localidades estudadas frente ao papel que essas exercem na construção das bases competitivas locais.

Por fim, vale destacar que as três etnias consideradas neste estudo apresentaram comportamento de respostas frente às questões de percepção, muito semelhante entre si e distintas entre os grupos étnicos.

\subsection{Recomendações e Restrições da Pesquisa}

Os resultados obtidos nesta pesquisa devem ser analisados e considerados levando-se em conta as restrições impostas pelo recorte metodológico utilizado para a elaboração estrutura analítica aqui apresentada, a estratégia de pesquisa utilizada e da especificidade do ambiente dos agronegócios de flores e plantas ornamentais.

Nesse sentido, considerando que a inclusão das organizações cooperativas/associativas não foram comumente consideradas em estudos similares, novos estudos que contem com a presença dessas organizações no contexto agroindustrial, poderão contribuir de maneira significativa para o aprimoramento da estrutura aqui proposta.

Com relação à estratégia de pesquisa utilizada para o desenvolvimento deste trabalho, dois aspectos devem ser considerados também para proporcionar a interpretação e análise mais segura dos resultados aqui apresentados: a não utilização de amostragem probabilística no estudo quantitativo e a utilização dos critérios de percepção por parte dos entrevistados, em grande parte do questionário utilizado na pesquisa.

A não utilização de amostragem probabilística, determinadas pelas condições operacionais da pesquisa, onde não seria possível garantir o número mínimo de produtores a serem entrevistados, dificulta a generalização dos resultados aqui obtidos, reforçando a necessidade do desenvolvimento de outros estudos, mencionados anteriormente. 
Com relação à adoção de instrumentos de coleta de dados com base na percepção dos entrevistados, não se pode deixar de considerar que os resultados assim obtidos podem ser restritos à essas percepções, o que em muitos casos, pode dificultar a generalização dos resultados obtidos dentro do próprio estudo.

A intensificação de estudos voltados à investigação do fator étnico na percepção e na construção das vantagens competitivas de uma localidade é um outro tema, que os resultados aqui encontrados, sugerem merecer a atenção de estudos futuros. O mesmo se aplica para a investigação da influencia sobre as percepções das vantagens e competências geradas por uma localidade, quando se está sediado dentro dela ou fora, apenas se beneficiando dessas vantagens e competências lá estabelecidas. 


\section{REFERÊNCIAS}

ABAG-ASSOCIAÇÃO BRASILEIRA DE AGRIBUSINESS. Caracterização do Complexo Agroindustrial Brasileiro. Brasília: Embrapa. 2001.

AFLORD - Associação dos Floricultores da Região da Via Dutra. Disponível em www.aflrod.org.br. Acesso em 27/10/2006 as 20:30 h.

AGRESTI, A. Categorical data analysis. New York: Wiley, 1990.

ALBUQUERQUE, M. E. E; da SILVA, FA C. Da estratégia competitiva a estratégia de manufatura: uma abordagem teórica. Read, v.8, n.2, p.1-20, maio 2002.

ALIMANDRO, R; PINAZZA, L.A.; WEDEKIN, I. (organizadores): NUNES, E.P.; CONTINI, E; PEROBELLI, F.S.; SCHOUCHANA, F. Agenda para competitividade do agribusiness brasileiro:base estatística 2001-2002. Rio de Janeiro: FGVABAG; São Paulo; 288p. 2001.

ALMEIDA, F.R.F; AKI, A.Y. Grande crescimento no mercado das flores. Agroanalysis. Rio de Janeiro, v.15, n.9, p.8-11, set. 1995.

ALMEIDA, J. B. S. A Agricultura Familiar - Projeto Flores. Irriga Ceará 2004 Encontro Estadual do Agronegócio Cearense -Secretaria de Agricultura e Pecuária do Estado do Ceará, Fortaleza. CD 2 (Palestras). 2004.

ALVEZ-MAZZOTTI; GEWANDSNADJER, F. O método nas ciências naturais e sociais: pesquisa qualitativa e quantitativa. São Paulo: Pioneira, 1998.

AMATO NETO, J. Redes de Cooperação Produtiva e Clusters Regionais. São Paulo: Atlas, 2000.

ANEFALOS, L. C. GUILHOTO, J. J. M. Estrutura do Mercado Brasileiro de Flores e Plantas Ornamentais. Agric. São Paulo, SP, 50(2):41-63, 2003.

ANSOFF, H. I. Estratégia empresarial. São Paulo : McGraw-Hill, 1977. 
ARRUDA, S.T.; OLIVETTI, M.P.A.; CASTRO, C.E.F. Diagnóstico da floricultura do estado de São Paulo. Revista Brasileira de Horticultura Ornamental. Campinas, 2(2):1-18.1996.

AWUAH, G B. A firm's competence development through its network of exchange relationships. Journal of Business \& Industrial Marketing, 16 (7 ) 574-599. 2001.

BAIR, J. \& GEREFFI, G. Local clusters in global chains: the causes and consequences of export dynamism in Torreon's blue jeans industry. World Development Vol. 29.N11. Elsevier Science. 1185-1903p. , 2001.

BATALHA, M.O. SCARPELLI, M. Gestão do Agronegócio: aspectos conceituais. IN: Batalha (Coord) Gestão do Agronegócio: textos selecionados. São Carlos, UFSCAR, 2005.

BRAGA, T.M. Município de Holambra IN: Cano, W \& Brandão, C A (coords.) A Região Metropolitana de Campinas: urbanização, economia, finanças e meio ambiente. Campinas, Editora da Unicamp, 2002. (Coleção Livro Texto)

BRUM, B.L.R. \& WEDEKIN, I. 0 agricluster de carnes de aves e suínos no sudoeste de Goiás. IN: I Congresso brasileiro de agribusiness (ANAIS). 57-84 p.2001.

BUSSAB, W. O. e MORETTIN, P. A. Estatística Básica. 4ª ed. São Paulo: Atual. 321 p. 1987.

CÂMARA et al. Cluster moveleiro no norte do Paraná e o sistema local de disseminação de inovações. Anais do IV SEMEAD. Outubro, 1999.

CAMPEÃO, P. Sistemas Locais de Produção agroindustrial:um modelo de competitividade. 2004.Tese (Doutoramento). Engenharia de Produção. Universidade Federal de São Carlos. 230p 2004.

CARVALHO, M.A. de; SILVA, C. R. da. Comercio Agrícola Brasileiro e geração de divisas. Informações Econômicas, São Paulo, 36:10.80-87p.2006. 
CARVALHO, M.M.; LAURINDO, F.J.B. Estratégias para Competitividade. São Paulo: Editora Futura, 272p. 2003.

CARVALHO, M.M.; MACHADO,S.A.; RABECHINI Jr, R. Fatores Críticos de Sucesso em Empresas de Base Tecnológica. Revista Produto \& Produção, vol. 4, número especial, p. 47-59, abril 2000.

CASSIOLATO, J. E. \& LASTRES, H. M. M. Aglomerações, Cadeias e Sistemas Produtivos e de Inovação. Revista Brasileira de Competitividade, (1): abril/julho, 2001.

CASSIOLATO, J.E.; LASTRES, H.M.M. Inovação, Globalização e as novas Políticas de Desenvolvimento Industrial e Tecnológico IN: Clusters e Sistemas locais de Inovação. Estudos de Casos e Avaliação da região de Campinas. IE/UNICAMP, 1999.

CASTRO, C.E.F. Cadeia produtiva de Flores e Plantas ornamentais. Revista Brasileira de Horticultura Ornamental. Campinas, 1-2(4):1-46.1998.

CAVALCANTI, M. Multigestão empresarial : uma estratégia de sobrevivência para a pequena e média empresa no Estado de São Paulo. Tese (Doutorado) Faculdade de Economia, Administração e Contabilidade da Universidade de São Paulo (FEA-USP), 298P, 1986.

CLARK, L. A.; WATSON, D. Constructing validity: basic issues in objective scale development. Psychological Assessment, v. 7, p. 309-319, 1995.

CLARO, D. P. Analise do Complexo Agroindustrial das Flores no Brasil. Dissertação de Mestrado, Lavras:UFLA, 103p., 1998.

CLARO.D.P.; OLIVEIRA, P.B. A comercialização de flores na Ceasa-Campinas e no Veiling Holambra. Revista Brasileira de Horticultura Ornamental. V5.n1. p 7077.1999.

CORREAA, R.L. Trajetórias geográficas. Rio de Janeiro: Bertrand Brasil, 1997. 302p. 
COSTA, G.G. de O. Um Procedimento Inferencial para Análise Fatorial Utilizando as Técnicas Bootstrap e Jackknife: Construção de Intervalos de Confiança e Testes de Hipóteses. 189p. Tese (Doutorado). Departamento de Engenharia Elétrica. Pontifícia Universidade Católica do Rio de Janeiro. 2006 .

COSTA, R.W. da \& CAIXETA FILHO, J.V. Mercado de flores e plantas ornamentais no Estado de São Paulo: avaliação da sazonalidade no Veiling de Holambra. Agric. São Paulo, São Paulo, 49(2):31-54.2002.

DOLAN, C.; HUMPHREY, J., Governance and trade in fresh vegetables: the impact of UK supermarkets on the African horticulture industry. Journal of Development Studies, Vol.37, n.2, pp. 1-37.2000

DREJER, A. A case of competence development. Int. J. Business Performance Management, Vol. 3, No. 1, 2001.

DUNPHY, D.; TURNER, D.; CRAWFORD, M. 'Organizationa I learning as the creation of corporate competencies ", Journal of Management Development, Vol. 16 No. 4, pp. 232-44. 1997.

FARINA E.M. M.Q.; AZEVEDO, P.F. SAES, M.S.M. Competitividade: mercado, estado e organizações. São Paulo. Editora Singular..285p. 1997.

FARINA, E M. M. Q., ZYLBERSZTAJN, Décio. Organização das cadeias agroindustriais de alimentos. In: ENCONTRO NACIONAL DE ECONOMIA,20., 1992, Campos de Jordão-SP. Anais. São Paulo, , p. 189-207. 1992.

FERRAZ, J.C.; KUPFER, D; HAGUENAUER, L. Made in Brasil: desafios competitivos para a indústria. Rio de Janeiro, Campus, 1997.

FERREIRA, A. B. H. Novo dicionário da língua portuguesa. Rio de Janeiro. Editora Nova Fronteira. 1 edição. 15 impressão. 1975.

FLOYD, F. J.; WIDAMAN, K. F. Factor analysis in the development and refinement of clinical assessment instruments. Psychological Assessment, v. 7, p. 309-319, 1995; 
FORZA, C. Survey Resarch in Ooperations Management: a Process-based Perpspective. International Journal of Operations and production Management. Vol 22. N 2 , 152-194p. 2002.

FRANSCISCO, V. L. dos; PINO, A.F.; KYIUNO, I. Floricultura no Estado de São Paulo. Informações Econômicas, São Paulo (3)33:17-32 Mar.2003a.

FRANSCISCO, V. L. dos; PINO, A.F.; KYIUNO, I. Os Floricultores no Estado de São Paulo. Informações Econômicas, São Paulo 12(33)33:77-80 Dez.2003b.

FURMAN, J.L.; PORTER, M.E. \& STERN, S. The determinants of national innovative capacity. Research Policy, 31:899-933 AMSTERDAM 2002.

GARCEZ, C.M. Sistemas Locais de Inovação na Economia do Aprendizado, uma abordagem conceitual. Revista do BNDES n. 142000

GARCIA, R. Learning an upgrading in indústrial clusters: the relation between local producers and global buyers. IN: EUNIP Annual Conference.(Anais) Porto. Portugal. 2003.

GEREFFI, G. International trade and indústrial upgrading in the apparel commodity chain, Journal of International Economics, Vol.48, pp.37-70. 1999

Beyond the Producerdriven/buyerdriven Dichotomy: The

evoltution of Global Value Chains in the intenet Era. IDS Bulletin Vol.32 N 3. 2001

GODOY, A. S. Pesquisa qualitativa: tipos fundamentais. Revista de Administração de Empresas. São Paulo, v.35, n.3, p.20-29, maio/jun. 1995.

GRANDORY, A.; SODA,G. Inter Firm Network Antecedents Mechanisms and Forms Organizations. Studies, v 16, n 2, p. 183-215., 1985 
GRAZIANO, T.T. Programa setorial integrado de exportação de flores e plantas ornamentais: relatório de produção de flores e plantas ornamentais brasileira. São Paulo: Ibraflor, 2002. 1 CD.

GREEN, P.E.; CARMNE, F.J. Multidimensional Scaling and Related Techniques in Marketing Analysis. Boston, Mass, 1988

GROOT, N S P. Floriculture worldwide trade and consumption patterns. Acta Horticulturae. $n^{\circ}$ 495. $p$ 101-121. 1999.

GÜNTHER, H. Como elaborar um questionário. In: Pasquali, L. (org.). Instrumentos psicológicos: manual prático de elaboração. Brasília: LabPAM/IBAPP, 1999.

HUMPREY, J. Opportunities for SMEs in Developing Countries to Upgrade in a Global Economy. SEED Working Paper n.43, 2003.

HUMPREY J. \& SCHMITZ, H.'Governance in global value chains', IDS Bulletin 32 (3) $19-29,2001$.

. Governance and upgrading: linking indústrial clusters and global value chain research. IDS Working Paper 120, p. 1-3 7, 2000.

IBGE-FUNDAÇÃO INSTITUTO BRASILEIRO DE GEOGRAFIA E ESTATÍSTICA (IBGE) site da internet: httpllwww.IBGE.gov.br acessado em 03/09/2003 às 21:45

IBRAFLOR- Instituto Brasileiro de Floricultura . Encontro de lideranças: programa de ações para a superação de gargalos e pontos de estrangulamento na cadeia produtiva de flores e plantas ornamentais do brasil (relatório final de atividades). Holambra: Ibraflor. 19p. 2006

IGLIORI, D.C. Economia dos Clusters Industriais e Desenvolvimento. Tese, Mestrado, Faculdade de Economia, Administração e Contabilidade, Universidade de São Paulo, São Paulo. 154p. 2000 
INDICADORES RURAIS. Participação do agronegócio cai para $35,8 \%$ Indicadores rurais. CNA: Brasília ANO X Nº 71 - setembro/outubro de 2006.

IPEA - INSTITUTO DE PESQUISA ECONOMICA APLICADA. Desempenho e crescimento do agronegócio no Brasil. Brasília: IPEA, janeiro de 2004. Disponível em http:II www.ipea.gov.br. Acesso em 25/11/2006 às 15:45h

IPEA.- INSTITUTO DE PESQUISA ECONOMICA APLICADA Caracterização e Tendências da Rede Urbana no Brasil: redes urbanas regionais; sudeste. Brasilia, IPEA, v5. 168p ('serie de 6 volumes) 2001.

JANK, M. S. Competitividade do agribusiness brasileiro: discussão teórica e evidências no sistema carnes. São Paulo, 195p. Tese (Doutorado) - Faculdade de Economia, Administração e Contabilidade da Universidade de São Paulo (FEAUSP), 1996.

JERÔNIMO, F. B. Confiança e os Mecanismos de Coordenação em Redes: A Experiência da Rede Formada por Sete Cooperativas Agroalimentares no Rio Grande do Sul.2005 Dissertação (Mestrado). UFRRS

JOHNSON, R. A. e WICHERN, D. W.. Applied Multivariate Statistical Analysis. $4^{a}$. ed. New Jersey. Prentice Hall. 816p. 1998

KIYUNA, I. et al. Estimativa do valor de mercado de flores e plantas ornamentais do estado de São Paulo. Informações Econômicas, São Paulo (5)32:07-22 Mar.2003.

KIYUNA et al.Floricultura brasileira no inicio do século XXI:o perfil do podutor. Informações Econômicas, São Paulo (4)34:14-32 Abr.2004.

KIYUNA, I. et al. Valor da Produção de Flores e Plantas Ornamentais nas áreas de abrangência dos Pólos Regionais da APTA 2002. Disponível em http:॥ www.iea.sp.gov.brl artigos.htm. Acesso em 11/01/2005 as 23:45 
LEDGERWOOD, G. \& BROADHURST, A.I. . Creating Technology based Enterprise Televillages. University of Greenwich Business School, London, UK. Cities, v. 16, no. 1, pp. 43-50. Elsevier Science. 1999.

LINS, H. N. Clusters indústriais, competitividade e desenvolvimento regional: da experiência à necessidade de promoção. Estudos Econômicos, São Paulo, v. 30, n. 2, p. 233-265, abr-jun 2000.

LOURENZANI, A E B S; PEREIRA FILHO, N. A ; da Silva, A. L. Utilização de comércio eletrônico na comercialização de hortícolas: um estudo de caso. 2002.

MAPA - MINISTÉRIO DA AGRICULTURA PECUÁRIA E ABASTECIMENTO. Agronegócio garantiu superávit de U\$ 34,1 bilhões em 2004 e exportações somaram U\$ $39 \quad$ bilhões. Disponível em http: II extranet.agricultura.gov.brlpuba...l!ap_detalhe_noticia_cons_web?p_id_publicação= 604. cesso em 11/01/2005 as $20: 15$

MAPA - MINISTÉRIO DA AGRICULTURA PECUÁRIA E ABASTECIMENTO. Disponívelemhttp:Illwww.agricultura.gov.br/portal/page? pageid=33,968707\& dad=p ortal\& schema=PORTAL acesso em 03/11/2006 às 10:05 h.

MARQUES, R. W. C.; CAIXETA FILHO, J. V. Mercado de flores e plantas ornamentais no Estado de São Paulo: avaliação da sazonalidade no Veiling Holambra. Agricultura em São Paulo vol. 49(2), , p. 31-54. 2002.

MARTELETTO, R.M.M. Análise de redes sociais - aplicação nos estudos de transferênciadainformação.Disponívelemhttp://www.scielo.br/scielo.php?script=sci a rttext\&pid=S0100-19652001000100009\&Ing=en\&nrm=iso. Acessoem 25/03/2005 as 23:07

MATTAR, F. N. Pesquisa de marketing. Metodologia, Planejamento, Execução e Análise: Vol. 1. São Paulo, Atlas, 350p. 1993 
MIGLINO, M.A.P.Inovação: o local importa? Um ensaio sobre os nexos entre inovação e espaço segundo autores contemporâneos selecionados. Dissertação (Mestrado) Unicamp, Campinas. 2003

MINTZBERG, H. Five steps for strategy. In: Mintzberg, Henry, Quinn, J. B. The strategy process. Rio de janeiro : Prentice Hall, p. 12-19. 1992.

MINTZBERG, H.; QUINN, D. O processo da estratégia. 3.ed. - Porto Alegre: Bookman, 2001.

MONTGOMERY, C A. \& PORTER, M.E. (Orgs.). Estratégia: a busca da vantagem competitiva. Rio de Janeiro : Campus, 1998

MOTOS, J R; NOGUEIRA JR, S.P. Flora Brasilis. Agroanalysis, v21 n.8 p39-40. 2001

MOTTA P.R. Gestão Contemporânea: a ciência e a arte de ser dirigiente. Rio de Janeiro. Efitora Record. 1991.

NADVI, K. Collective Efficiency and Collective Failure: The Response of the Sialkot Surgical Instrument Cluster to Global Quality Pressures. Institute of Development Studies, Brighton, UK. 1999.

NAKAMURA, P. R. Estratégia Empresarial para pequenas e Médias Empresas. São Carlos. Dissertação de Mestrado. Escola de Engenharia de São Carlos. Universidade de São Paulo. 1999.

NEVES, M $\mathrm{F}$ et al. Cenários e perspectivas para 0 agribusiness. In: CONGRESSO BRASILEIRO DE ECONOMIA E SOCIOLOGIA RURAL, 35. 1997, Natal. Anais. Natal,. p. 246-261. 1997

NEVES, M.F.; CHADDAD, R. \& LAZZARINI, S.G. Gestão de Negócios em Alimentos. São Paulo. Pioneira, 129p. 2002. 
NUNES, E.P. ; CONTINI, E. Complexo Agroindústrial Brasileiro: caracterização e Dimensionamento.São Paulo: ABAG/Embrapa.; 109p.2001.

PASQUALI, L. Testes referentes a construto: teoria e modelo de construção. In: Pasquali, L. (org.). Instrumentos psicológicos: Manual prático de elaboração. Brasília: LabPAM/IBAPP, 1999.

PORTER M; MILLAR V.E. How information gives you competitive advantage. Harvard Business Review Vol 63 Issue 4 Jun/July 1985 pp 149-160 .

PORTER, M. E Estratégia competitiva: técnicas para análise de indústrias e da concorrência. Rio de Janeiro : Campus, 1991.

. Vantagem competitiva das nações. Tradução de: Waltersin Dutra. Rio de Janeiro: Campus, 897p. Tradução de: The competitive advantage of nations. 1993.

1996.

. What is strategy. Havard Business Review, (s.n.t.), nov./dec.

. Clusters and the new economics of competition. Harvard Business Review, 77-90p. nov-dec.1998

PRAHALAD, C.K.; RAMASWANY, V. , Co-opting customer competence'. Harvard Business Review, Vol. 78, pp. 79-90. 2000.

PRAHALAD,C.K.; HAMEL, G. The Core Competence of the corporation. Harvard Business Review, mai-jun, 1990.

QUINN, J. B. Strategies for change. In: Mintzberg, H., Quinn, J. B. The strategy process. Rio de janeiro : Prentice Hall, p. 4-12. 1992. 
RABELOTTI, R. Recovery of a mexican cluster: devaluation bonanza or collective efficiency. IDS Working Paper 71, Institute of Development Studies, University of Sussex. 1997

RELVAS, T R. S. Análise de cadeia de valor. Em $20^{\circ}$ ENCONTRO ANUAL DA ASSOCIAÇÃO NACIONAL DOS PROGRAMAS DE OÓS-GRADUAÇÃO EM ADMINISTRAÇÃO, 1996, Angra dos Reis/Rio de Janeiro. Anais... Angra dos Reis, p. 17-35. 1996.

RIETJENS, L. Holambra: emigração e cooperativismo. Cooperativa Agopecuária Holambra. Holambra. Não publicado. 2002.

SANTOS, R da C. Cooperativa Agropecuária de Holambra: uma organização em mudança. IN: Zylbersztajn, D. (coord). Estudos de casos em agribusiness. O processo de decisão nas empresas brasileiras. Pensa-USP. Porto Alegre. 1993.

SANTOS, V.L.F; KIYUNA, I. Floricultura no Estado de São Paulo: novas fronteiras. Disponível em http:॥ www.iea.sp.gov.brl artigos.htm. Acesso em $11 / 10 / 2004$ as $23: 00$

SCHERER- WARREN, I. Cidadania sem fronteiras: ações coletivas na era da globalização. São Paulo: Hucitec, 1999.

SCHIMTZ, H. Collective Efficiency: growth path for small scale industry. The Journal of Development Studies, v. 31, n. 4, p. 529-566, 1995.

SCHMITZ, H, NADIV, K. Clustering and indústrialization: introduction. World Development, v. 27, n. 9, p. 1503-14, 1999.

SCHMITZ, H. Collective Efficiency and Increasing Returns. IDS Working Paper no. 50. Institute of Development Studies, University of Sussex, Brighton, March. 1997

SCHMITZ, H. Small firms and flexible specialisation in LDCs. Institute of Development Studies - IDS, University of Sussex, 1989. 
SCOTT,A; STORPER, M. Indústria de alta tecnologia. e desenvolvimento regional: uma crítica e reconstrução Porter, M.E. (1979). "How Competitive forces shape strategy". Harvard Business Review, p.137-145, Nov-Dec.1988

SEADE - FUNDAÇÃO SEADE - internet: httpllwww.seade.spgov.br acesso em $03 / 09 / 2003$ às $20: 35$

SELITIZ; JAHODA; DEUTSCH e COOK. Método de Pesquisa das Relações Sociais. São Paulo: Pedagógica, 1975.

SHELMAN, M.L. The Agribusiness System Approach: cases and concepts. Procidings of the international Agribusiness Management Association inaugural Symposium. Boston, 47-51p.1991.

SILVA, C. M. De S. Política de desenvolvimento regional na União Européia. O que podemos aprender? Revista do BNDES, Rio de Janeiro, v7. n14. p 125-144.2000

SLACK, N.; CHAMBERS, S.; JOHNSTON, R. Administração da produção. $2^{\circ}$ edição.São Paulo, Editora Atlas. 2002.

SPFLORES, 2006 http://www.spflores.com.br/empresa.asp; Acesso em 25/11/2006 ás 17:45

STEINLE, C. \& SCHIELE, H. When do indústrial cluster? A proposal on how to asses an industry's propensity to concentrate at single region or nation. Research Policy 31:849-858 2002.

SUZIGAN, W.; FURTADO, J.; GARCIA, R. Cluster ou sistema s locais de produção ou inovação: identificação, caracterização e medidas de apoio, Campinas, IEDI. Maio, 30p. 2002.

SUZIGAN, W.; FURTADO, J.; GARCIA, R.; SAMPAIO; S. E.K. Aglomerações indústriais como foco de políticas. Revista de Economia Política, vol.21, no.3(83), p.27-39, jul-set/2001. 
TÁLAMO, J. R. ; CARVALHO, M.M. Seleção dos objetivos fundamentais de uma rede de cooperação empresarial. Gestão \& Produção, São Carlos. Vol. 11. n.2 ; 1 20 p. 2004

WIJNEN, K. Holambra, 1948-1998. A cooperativa de agricultores e horticultores holandeses que se transforma na cidade das flores do Brasil. Haia. Holambra. 198p. Ilust. 1998.

WILLIAMSON,O.E. The economic institutions of capitalism: firmas, market, relational contracting. New York, The Free Press, 1985.

WOOD Jr; PICERELLI, T. Remuneração estratégica. A nova vantagem competitiva. São Paulo, Editora Atlas. 1996.

YIN, R. K. Estudo de Caso: planejamento e Métodos.Tradução de: Daniel Grassi. 2ed. Porto Alegre: Bookman, 205p .2001.

ZYLBERSZTAJN, D. Estruturas de governança e coordenação do agribusiness: uma aplicação da nova economia das instituições. São Paulo: USP,. 238p. (Tese de Livre Docência em Administração) 1995.

ZYLBERSZTAJN, D. \& NEVES, M.F. (organizadores) Economia e Gestão dos negócios agroalimentares. São Paulo, Pioneira. 428p.2000. 
ANEXO A

ROTEIROS DE ENTREVISTAS - PESQUISA QUALITATIVA 


\section{ROTEIRO DE ENTREVISTAS - ASSOCIACÃO DE PRODUTORES}

\section{BLOCO 1 - CARACTERIZAÇÃO}

\subsection{DADOS DO RESPONDENTE}

NOME

CARGO / FUNÇÃO ENTIDADE

TELEFONE PARA CONTATO:

E-MAIL:

\subsection{A ENTIDADE}

\subsubsection{DADOS GERAIS}

Nome da Associação

\begin{tabular}{l|l|l}
\hline Telefone/Fax: & Ano de inicio das atividades: & $N^{\circ}$ de Associados
\end{tabular}

Caso desenvolva algum tipo de atividade comercial, por favor, informe o faturamento anual (aproximado): $\mathrm{R} \$$

1.23. ASSINALE EM QUAL DOS SEGMENTOS ABAIXO QUE SEUS ASSOCIADOS ESTÃo INSERIDOS.

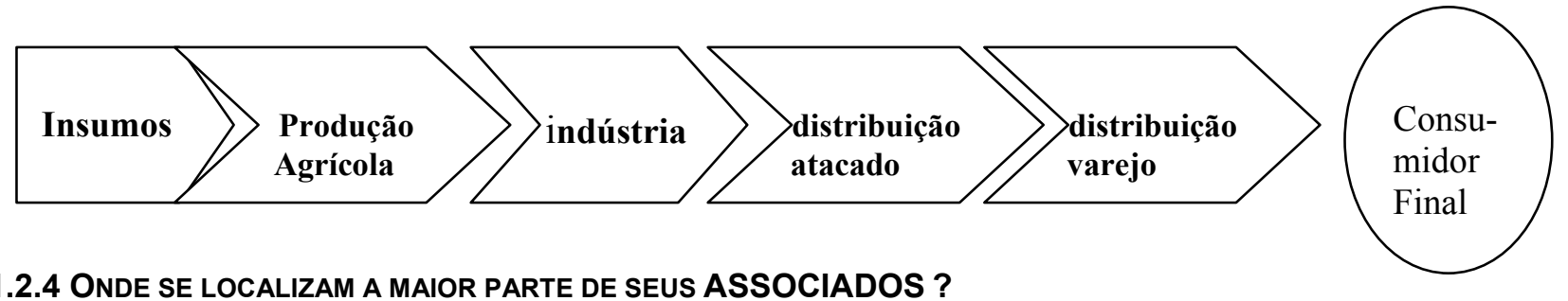

\subsubsection{ONDE SE LOCALIZAM A MAIOR PARTE DE SEUS ASSOCIADOS ?}

\subsubsection{CASO ESTA ENTIDADE ESTEJA DESENVOLVENDO ALGUMA ATIVIDADE ESPECIFICA EM RELAÇÃO A} FLORICULTURA FAVOR ESPECIFICAR EM QUE MUNICIPIO(S) E QUAL A ATIVIDADE. INCLUÍ-SE ATIVIDADES DESENVOLVIDAS EM PARCERIAS COM OUTRAS ENTIDADES

\subsection{PAPEL DA ENTIDADE}

ESTA ENTIDADE ESTABELECE CONTATO FREQÜENTE COM TÉCNICOS DA CATI, AUXILIANDO NO DESEMPENHO DAS ATIVIDADES PRODUTIVAS DE NOSSOS ASSOCIADOS .

ESTA ENTIDADE INCENTIVA AS AÇÕES DE PARCERIA ENTRE OS ATORES DA CADEIA DE FLORES

ESTA ENTIDADE ATUA NO DESENVOLVIMENTO DE INOVAÇÕES DE PRODUTOS

ESTA ENTIDADE DESENVOLVES PESQUISAS FREQÜENTES COM O IAC E A EMBRAPA

ESTA ENTIDADE DESENVOLVE FREQÜENTES PESQUISAS TÉCNICAS DA ÁREA DE PRODUÇÃO E CULTIVO

ESTA ENTIDADE É ATUANTE NO SENTIDO DE PROMOVER O DESENVOLVIMENTO DOS AGRONEGÓCIOS DE FLORES DE SEUS ASSOCIADOS

ESTA ENTIDADE AUXILIA SIGNIFICATIVA NA CONSTRUÇÃO DE POLITICAS PÚBLICAS PARA O SETOR A ASSOCIAÇAO DEFINE O NUMERO DE ESPÉCIES QUE OS ASSOCIADOS PODEM CULTIVAR A ASSOCIAÇAO ESTREITA OS LAÇOS DE RELACIONAMENTO E CONFIANÇA ENTRE OS PRODUTORES A ASSOCIAÇAO PROMOVE COM FREQÜÊNCIA O TREINAMENTO/CAPACITAÇÃO DOS PRODUTORES E/OU SEUS EMPREGADOS

A ASSOCIAÇAO DIVULGA COM FREQÜÊNCIA OS AGENTES E AS LINHAS DE FINANCIAMENTOS DISPONIVEIS.

EsTA ASSOCIAÇÃO TEM CONSCIÊNCIA DE QUE A FALTA DE CLAREZA DAS NORMAS DE FINANCIAMENTO DOS AGENTES, BUROCRACIA E EXCESSO DE GARANTIAS DIFICULTAM O ACESSO AOS RECURSOS POR PARTE DE NOSSOS ASSOCIADOS

ESTA ASSOCIAÇÃO ESTIMULA O CONTATO DE DOS ASSOCIADOS COM PRODUTORES E/OU EMPRESAS DE OUTRAS EMPRESAS DA REGIÃO. 
1.4. QUAIS SERVIÇOS QUE OS PRODUTORES BUSCAM NESTA ENTIDADE E COM QUE FREQÜÊNCIA.

\begin{tabular}{|l|l|l|l|}
\hline \multicolumn{1}{|c|}{ Serviço } & $\begin{array}{c}\text { Nenhuma } \\
\text { freqüência }\end{array}$ & Pouca freqüência & $\begin{array}{c}\text { Muita } \\
\text { freqüência }\end{array}$ \\
\hline Comercialização de produtos & & & \\
\hline Compra de insumos & & & \\
\hline Consorcio de Exportação & & & \\
\hline Participação em feiras e eventos & & & \\
\hline Assessoria jurídica & & & \\
\hline Assessoria administrativa & & & \\
\hline Informações sobre outras Empresas/ASSOCIAÇAO s & & & \\
\hline Informações de mercado & & & \\
\hline Boletins de informação & & & \\
\hline Novas Variedades & & & \\
\hline Assessoria tecnológica de produção e armazenamento & & & \\
\hline Capacitação de mão-de-obra & & & \\
\hline Cursos e seminários para o produtor & & & \\
\hline Acesso/conhecimento de novas tecnologias & & & \\
\hline Acesso/conhecimento de linhas de crédito & & & \\
\hline Outros(favor especificar) & & & \\
\hline
\end{tabular}

1.5. CASO ESTA ASSOCIAÇÃo PARTICIPE DE ALGUMA ATIVIDADEDE COMERCILIZAÇÃo DOS PRODUTOS DE SEUS ASSOCIADOS É CORRETO AFIRMAR QUE, PELA PERCEPÇAO DESSES ASSOCIADOS

A ASSOCIAÇAO DISTRIBUI E COMERCIALIZA OS PRODUTOS DE MANEIRA MAIS EFICIENTE DO QUE SE O PRODUTOR FIZESSE ISSO SOZINHO

A ASSOCIAÇAO ESTABELECE OS PREÇOS DE VENDA E AS CONDIÇÕES PARA RECEBIMENTO DAS VENDAS POR PARTE DE SEUS ASSOCIADOS

A ASSOCIAÇÃO OU AGENTE DISTRIBUIDOR A QUAL A MAIORIA DE NOSSOS ASSOCIADOS ESTÁ ATRELADA, ESTABELECE OS PREÇOS DE VENDA E AS CONDIÇÕES PARA RECEBIMENTO DAS VENDAS DE SEUS PRODUTOS

\section{BLOCO 2-COOPERAÇÃO/PARCERIA}

2.1 Estabeleceu AÇÕEs DE COOPERAÇÃo E/OU PARCERIAS COM OUTROS PRODUtORES, FORNECEDORES, CLIENTES E/OU OUTRAS EMPRESAS QUE ATUAM EM SUA MESMA ÁREA DE NEGÓCIOS?

2.2. QUAIS OS PRINCIPAIS MOTIVOS DAS AÇÕES DE PARCERIA QUE FORAM DESENVOLVIDAS PELOS SES ASSOCIADOS E COM QUAL FREQUENCIA?

\begin{tabular}{|l|l|l|l|l|}
\hline \multicolumn{2}{|c|}{ Cooperação/Parceria } & \multicolumn{3}{c|}{ FREQÜẾNCIA } \\
\hline & Nenhuma & Alta & Mediana & Baixa \\
\hline $\begin{array}{l}\text { Outros produtores rurais que cultivam as mesmas } \\
\text { espécies que são cultivadas em sua propriedade }\end{array}$ & & & & \\
\hline $\begin{array}{l}\text { Outros produtores rurais que cultivam as outras espécies } \\
\text { que são cultivadas em sua propriedade }\end{array}$ & & & & \\
\hline Clientes situados no Brasil & & & & \\
\hline Clientes situados no Exterior & & & & \\
\hline SEBRAE & & & & \\
\hline SENAR & & & & \\
\hline Entidades de pesquisa (IAC, EMBRAPA, etc.) & & & & \\
\hline Casa da Agricultura-CATI & & & & \\
\hline Esta associação não tem essa informação & & & & \\
\hline Outros (favor especificar) & & & & \\
\hline
\end{tabular}


2.3. CASO ESTA ENTIDADE TENHA IDENTIFICADO ALGUM TIPO DE PARCERIA NA QUESTÃO ANTERIOR, POR FAVOR, QUAIS OS PRINCIPAIS MOTIVO QUE LEVARAM SEUS ASSOCIADOS A DESENVOLVEREM TAIS AÇÕES DE COOPERAÇÃO OU PARCERIA.

COMPARTILHAR INSTALAÇÕES DE PRODUÇÃO

COMPARTILHAR A UTILIZAÇÃO DE EQUIPAMENTOS DE PRODUÇÃO, ESTUFAS, ETC.

COMPARTILHAR INSTALAÇÕES DE PESQUISA

PARTICIPAÇÃO CONJUNTA EM FEIRAS (NACIONAIS E/OU INTERNACIONAIS), EXPOSIÇÕES, ETC.

COMPARTILHAR A ESTRUTURA DE VENDAS (CANAIS, PROPAGANDA, MARCA, ETC.)

COMPRAS CONJUNTAS DE INSUMOS E EQUIPAMENTOS

PARTICIPAÇÃO EM CONSÓRCIOS DE EXPORTAÇÃO

COMPARTILHAMENTO DE IDÉIAS E INFORMAÇÕES (TÉCNICAS, ORGANIZACIONAIS, ETC), NOVIDADES TECNOLÓGICAS,

DESENVOLVIMENTO OU MELHORIA DE INSUMOS, PRODUTOS OU PROCESSOS DE PRODUÇÃO

TREINAMENTO DE PESSOAL - CURSOS - DIA DE CAMPO

CAPACITAÇÃO PARA ATENDER AOS REQUISITOS DO PRODUTO IMPOSTOS PELO CLIENTE

CAPACITAÇÃO PARA ATENDER AOS REQUISITOS DO PRODUTO IMPOSTOS PELO FORNECEDOR

ACESSO À TECNOLOGIA

OUTROS

\section{4." A MAIORIA DAS AÇÕES DE PARCERIAS E/OU COOPERAÇÃO DESENVOLVIDA POR} PELOS PRODUTORES QUE ESTA ENTIDADE TEM CONTACTO, SURGIU...."

ATRAVÉS DE LAÇOS FAMILIARES.

CONVÍVIO COM OUTROS MEMBROS DESTA ENTIDADE E/OU ASSOCIAÇÃO DE PRODUTORES.

COMUNIDADE ÉTNICA DA QUAL SÃO DESCENDENTES

CONSOLIDAÇÃO DAS RELAÇÕES COMERCIAIS, COM O TEMPO

PELO INCENTIVO/INTERMEDIAÇÃO DO SINDICATO PATRONAL, E/OU SINDICATO DE TRABALHADORES; ENTIDADES COMO SEBRAE, SENAR, ASSOCIAÇÃO COMERCIAL LOCAL; ETC.

INDEPENDENTEMENTE DE LAÇOS CULTURAIS E/OU DE ASCENDÊNCIA ESTRANGEIRA, FORAM ESTABELECIDAS TAIS AÇÕES POR QUE SEI DA IMPORTÂNCIA DELAS PARA O FORTALECIMENTO DA ESTRUTURA DE PRODUÇÃO E/OU COMERCIALIZAÇÃO DA QUAL DEPENDEM SEUS ASSOCIADOS.

2.5. PARTICIPA.ALGUM TIPO de AsSOCIAÇÃo? PROdUTORES (LOCAL OU REgIONAL), AsSOCIAÇÃo COMERCIAL LOCAL OU ASSOCIAÇÕES LOCAIS RELACIONADAS A OUTROS FINS, NÃO VOLTADAS AO DESENVOLVIMENTO DE SEUS NEGÓCIOS

2.6. EM CASO AFIRMATIVO DA QUESTÃO ANTERIOR, ESPECIFIQUE QUAIS SERVIÇOS ESTA COOPERATIVA SE UTILIZA DAS ASSOCIAÇÕES DA QUAL É FILIADA E COM QUAL FREQÜÊNCIA

\begin{tabular}{|l|l|l|l|}
\hline \multicolumn{1}{|c|}{ Serviço } & $\begin{array}{c}\text { Nenhuma } \\
\text { freqüência }\end{array}$ & Pouca freqüência & $\begin{array}{c}\text { Muita } \\
\text { freqüência }\end{array}$ \\
\hline Comercialização de produtos & & & \\
\hline Compra de insumos & & & \\
\hline Consorcio de Exportação & & & \\
\hline Participação em feiras e eventos & & & \\
\hline Assessoria jurídica & & & \\
\hline Assessoria administrativa & & & \\
\hline Informações sobre outras Empresas/Cooperativas & & & \\
\hline Informações de mercado & & & \\
\hline Boletins de informação & & & \\
\hline Lobby & & & \\
\hline Capacitação de mão-de-obra & & \\
\hline Cursos e seminários para o produtor & & & \\
\hline Acesso/conhecimento de novas tecnologias & & & \\
\hline Acesso/conhecimento de linhas de crédito & & & \\
\hline Outros (favor especificar) & & & \\
\hline
\end{tabular}


2.7. CASO ESTA ASSOCIAÇÃO TENHA ESTABELECIDO PARCERIAS COM OUTROS PRODUTORES, CLIENTES, FORNECEDORES OU OUTRAS EMPRESAS QUE ATUEM NO SETOR DE AGRONEGÓCIOS DE FLORES E PLANTASPOR FAVOR, ESPECIFIQUE O(S) MOTIVO(S QUE O LEVARAM A TAL ATITUDE.

\begin{tabular}{|l|l|}
\hline \multicolumn{1}{|c|}{ Motivos promotores das Ações Conjuntas/ Parcerias } & \\
\hline Compartilhar instalações de produção & \\
\hline Compartilhar a utilização de equipamentos de produção, estufas, etc. & \\
\hline Compartilhar instalações de pesquisa & \\
\hline Participação conjunta em feiras (nacionais e/ou internacionais), exposições, etc. & \\
\hline Compartilhar a estrutura de vendas (canais, propaganda, marca, etc.) & \\
\hline Compras conjuntas de insumos e equipamentos & \\
\hline Participação em consórcios de exportação & \\
\hline $\begin{array}{l}\text { Compartilhamento de idéias e informações (técnicas, organizacionais, etc), novidades } \\
\text { tecnológicas, }\end{array}$ & \\
\hline Desenvolvimento ou melhoria de insumos, produtos ou processos de produção & \\
\hline Treinamento de pessoal - cursos - dia de campo & \\
\hline Capacitação para atender aos requisitos do produto impostos pelo cliente & \\
\hline Capacitação para atender aos requisitos do produto impostos pelo fornecedor & \\
\hline Acesso à tecnologia & \\
\hline Outros (favor especificar): & \\
\hline
\end{tabular}

\subsection{QUANTO AO(S) MOTIVO(S) QUE OS LEVARAM A DESENVOLVEREM TAIS AÇÕES DE COOPERAÇÃO OU PARCERIA.}

\section{Motivos promotores das Ações Conjuntas/ Parcerias}

Compartilhar instalações de produção

Compartilhar a utilização de equipamentos de produção, estufas, etc.

Compartilhar instalações de pesquisa

Participação conjunta em feiras (nacionais e/ou internacionais), exposições, etc.

Compartilhar a estrutura de vendas (canais, propaganda, marca, etc.)

Compras conjuntas de insumos e equipamentos

Participação em consórcios de exportação

Compartilhamento de idéias e informações (técnicas, organizacionais, etc), novidades

tecnológicas,

Desenvolvimento ou melhoria de insumos, produtos ou processos de produção

Treinamento de pessoal - cursos - dia de campo

Capacitação para atender aos requisitos do produto impostos pelo cliente

Capacitação para atender aos requisitos do produto impostos pelo fornecedor

Acesso à tecnologia

Outros (favor especificar):

\section{BLOCO 3 - LOCALIDADE}

EM TERMOS GERAIS, QUAL É A REGIÃO DE MAIS IMPORTANTE PARA OS AGRONEGÓCIOS DE FLORES E PLANTAS no Estado de São Paulo: Holambra, Mogi das Cruzes, Atibaia ou Registro?

O MUNICÍPIO (REgIÃO) DE HOLAMBRA/MOgI DAS CRUZES POSSIBILITA MELHORES CONDIÇÕES PARA O DESEMPENHO DOS NEGÓCIOS DE FLORES, SE COMPARADO À OUTROS MUNICÍPIOS E/OU REGIÕES DO BRASIL

A GERAÇÃO DE CONHECIMENTO REFERENTE A TECNOLOGIA DE PRODUÇÃO E COMERCIALIZAÇÃO DE FLORES E

PLANTAS É UM DOS PRINCIPAIS FATORES DE SUCESSO PARA A OS AGRONEGÓCIOS DE FLORES E PLANTAS 
ORNAMENTAIS? ESSA GERAÇÃO ESTÁ CONCENTRRADA PRIORITARIAMENTE CONCENTRADA NO MUNICÍPIO DE HOLAMBRA E REGIÃO?

O MUNICÍPIO DE HOLAMBRA E REGIÃO É A ÁREA MAIS IMPORTANTE DOS AGRONEGÓCIOS DE PLANTAS E FLORES DO BRASIL, NO TOCANTE AO PROCESSO DE COMERCIALIZAÇÃO

AONDE SE CONCENTRA PRIORIRATRIAMENTE A GERAÇÃO DE CONHECIMENTO E TECNOLOGIA RELACIONADA AOS AGRONEGÓCIOS DE FLORES E PLANTAS NO BRASIL? ESTÁ CONCENTRADA NOS CENTROS DE PESQSUISA AGROPECUÁRIOS, COMO EMBRAPA E IAC OU ESTÁ CONCENTRADA NAS EMPRESAS PRIVADAS DE INSUMOS E MAQUINÁRIOS?

O GOVERNO LOCAL É ATUANTE NO SENTIDO DE PROMOVER O DESENVOLVIMENTO DOS AGRONEGÓCIOS DE FLORES NA REGIÃO?

OS RESULTADOS DE DESEMPENHO DE NEGÓCIOS DE SEUS ASSOCIADOS SÃO SUPERIORES AQUELES QUE PODERIAM SER OBSERVADOS SE ESTIVESSEM LOCALIZADOS EM OUTRA REGIÃO?

QUAIS AS PRINCIPAIS VANTAGENS QUE A LOCALIZAÇÃO DE SEUS ASSOCIADOS NO MUNICÍPIO DE HOLAMBRA E REGIÃO QUE ESTA ASSOCIAÇÃO PODE IDENTIFICAR?

Melhor acesso à matéria-prima, infra-estrutura e assistência técnica

Possibilidade de criar parcerias

Maior acesso ao mercado consumidor

Aproximação com outros produtores possibilitando desenvolvimento de novos produtos e/ou novas técnicas de produção

Disponibilidade de mão-de-obra e treinamento

Apoio de entidades, associações de classe, SENAR, SEBRAE, associação comercial, etc.

Dificulta a entrada de novos atores que não tenham nenhum vínculo com a localidade, devido a dificuldade de aceitação dos mesmos por parte do grupo de atores local Facilita a comercialização e distribuição dos produtos

Ser beneficiado por estar inserido num pólo de excelência na produção e comercialização de flores e plantas

Nestes municípios é que se concentram os melhores especialistas e infra-estrutura em comercialização e produção de flores do país

QUAIS AS PRINCIPAIS DESVANTAGENS QUE A LOCALIZAÇÃO DE SEUS ASSOCIADOS NESTE MUNICÍPIO/NESTA REGIÃO O QUE ESTA ASSOCIAÇÃO PODE IDENTIFICAR?

Contribui para a saturação das possibilidades de produção local

Aumento das rivalidades e conflitos entre os concorrentes

Pressiona os custos com infra-estrutura para cima

Pressiona os salários para cima

Problemas de circulação - trânsito

Acelera ao desgaste da infra-estrutura local

Acaba por atrair produtores de outras regiões, principalmente para a comercialização de seus produtos, e isso vai deteriorando as fortes relações entre os produtores locais

Dificuldades em distribuir os produtos pela saturação dos distribuidores locais

Outras

COM RELAÇÃO À PERCEPÇÃO DE COMO OS PROFISSIONAIS DOS AGRONEGÓCIOS, RECONHECEM ESTE MUNICÍPO E REGIÃO. PODEMOS AFIRMAR QUE TAL RECONHECIMENTO SE DÁ...

pela produção de flores

pelo comércio de flores

pelos agronegócios em geral

pelo turismo relacionado a flores e as tradições culturais

pela fruticultura

pela cultura de hortaliças

devido a produção animal (suinocultura, aves de postura e/ou corte)

pela excelência tecnológica em cultivo protegido (estufa)

Por outros motivos ( por favor, especifique) 
O FORTE TRAÇO ÉTNICO-CULTURAL, POR EXEMPLO ORIENTAIS OU HOLANDESES (OU SEUS DESCENDENTES) FACILITA MUITO O DESENVOLVIMENTO PARCERIAS E AUMENTA A CONFIANÇA MÚTUA.

ESTE MUNICIPIO/REGIÃO PODE SER CONSIDERADO COMO UM PÓLO DE EXCELÊNCIA EM CULTIVO PROTEGIDO

\section{BLOCO 4- INOVAÇÃO/INFORMAÇÕES}

4.1. IDENTIFIQUE A(S) FONTE(S) DE INFORMAÇÃo (ÕES) MAIS IMPORTATES, PARA GERAR NOVOS CONHECIMENTOS PARA O DESENVOLVIMENTO DOS NEGÓCIOS DESTA

\section{FONTE}

Conversas informais

Entidades de apoio (SEBRAE, SENAR, centros de tecnologia)

Fornecedor de maquinário

Feiras e eventos similares

Dia de Campo

Entidades de classe (sindicatos, associações comerciais, e etc.)

Publicações especializadas

Visitas a outras empresas e/ou propriedades da região

Clientes

Vendedores

Empresas do exterior que tenho contato freqüente

\section{FONTE}

Visitas a empresas e/ou propriedades de fora da região

Funcionários que trabalharam em outras empresas ou propriedades

Consultores especializados da região

Consultores especializados de outras regiões

Revistas especializadas

Serviços da ASSOCIAÇAO e/ou associação

da qual sou filiado

$\mathrm{Na}$ troca de informações com outros

produtores

Vendedores e técnicos das empresas de

insumo e/ou infra-estrutura

Assistência técnica governamental

Assistência técnica privada

Outras: (especificar, por favor)

4.2. QUANTO À ORIGEM DAS INOVAÇÕES TECNOLÓGICAS DE SEUS ASSOCIADOS

\begin{tabular}{|l|l|l|l|l|l|}
\hline & Sempre & $\begin{array}{c}\text { Na } \\
\text { maioria } \\
\text { das } \\
\text { vezes }\end{array}$ & $\begin{array}{c}\text { Rarame } \\
\text { nte }\end{array}$ & Nunca & Não Sabe \\
\hline $\begin{array}{l}\text { Estão embutidas nas máquinas compradas no } \\
\text { mercado nacional }\end{array}$ & & & & & \\
\hline $\begin{array}{l}\text { Estão embutidas nas máquinas compradas no } \\
\text { mercado internacional }\end{array}$ & & & & & \\
\hline $\begin{array}{l}\text { São desenvolvidas internamente nas } \\
\text { propriedades }\end{array}$ & & & & & \\
\hline São adaptadas internamente nas propriedades & & & & & \\
\hline $\begin{array}{l}\text { São desenvolvidas em cooperação com } \\
\text { fornecedores }\end{array}$ & & & & & \\
\hline São geradas por fornecedores estrangeiros & & & & & \\
\hline São geradas por fornecedores domésticos/locais & & & & & \\
\hline São geradas por clientes estrangeiros & & & & & \\
\hline São geradas por fornecedores locais/domésticos & & & & & \\
\hline São desenvolvidas em cooperação com clientes & & & & & \\
\hline $\begin{array}{l}\text { São desenvolvidas em cooperação com outras } \\
\text { empresas locais }\end{array}$ & & & & & \\
\hline Outra Origem especificar) & & & & & \\
\hline
\end{tabular}




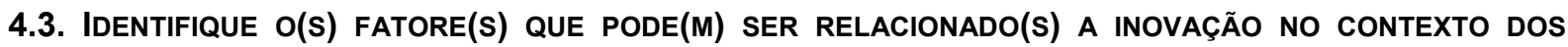
AGRONEGÓCIOS DE FLORES E PLANTAS FONTE

Variedades, cultivares, etc

Técnicas de cultivo

Técnicas de armazenagem

Adaptação de espécies às

coindições locais de cultivo

Desenvolvimento de Máquinas e

Equipamentos

Selos de origem e/ou qualidade

Outros (por favor, especificar)

\section{FONTE}

Desenvolvimento de Embalagens para produto final (flores e plantas)

Veiling

Técnicas de adubação e controle fitossanitário

Comercialização

Processos administrativos da propriedade rural

Marca própria

\section{BLOCO 5-BLOCO 5- GESTÃO / ESTRATÉGIAS DE}

\subsection{COM RELAÇÃO VISÃO GERAL DOS AGRONEGÓCIOS DE FLORES NO ESTADO DE SÃO PAULO}

O MERCADO NACIONAL DE FLORES E PLANTAS É UMA OPORTUNIDADE CRESCENTE DE NEGÓCIO PARA OS PRODUTORES DE FLORES E PLANTAS

O MERCADO INTERNACIONAL DE FLORES E PLANTAS É UMA OPORTUNIDADE CRESCENTE DE NEGÓCIO PARA OS PRODUTORES BRASILEIROS

A PRESENÇA DE UM AGENTE COORDENADOR NA CADEIA DE PRODUÇÃO E COMERCIALIZAÇÃO DE FLORES E PLANTAS É UM FATOR ESSENCIAL PARA O SUCESSO DESSE TIPO DE NEGÓCIO? ESTE AGENTE DEVE NECESSARIAMENTE SER UM REPRESENTANTE DOS PRODUTORES RURAIS?

A FALTA DE POLÍTICAS PÚBLICAS PARA O SETOR INTERFERE DE FORMA SIGNIFICATIVA E NEGATIVAMENTE NO DESEMPENHO DOS AGRONEGÓCIOS DE FLORES

O DESCONHECIMENTO DE FONTES DE FINANCIAMENTO, POR PARTE DOS PRODUTORES, É UM DOS PRINCIPAIS FATORES QUE PREJUDICAM UM MELHOR DESEMPENHO DOS NEGÓCIOS DE FLORES

A ALTA BUROCRACIA E EXIGÊNCIAS PARA OBTENÇÃO DE FINANCIAMENTOS, É UM DOS PRINCIPAIS FATORES QUE PREJUDICAM UM MELHOR DESEMPENHO DOS NEGÓCIOS DE FLORES

O COOPERATIVISMO E/OU ASSOCIATIVISMO É UM FATOR ESSENCIAL PARA O SUCESSO DOS AGRONEGÓCIOS DE FLORES E PLANTAS ORNAMENTAIS

A IDENTIDADE ÉTNICA E CULTURAL FAVORECEM AS RELAÇÕES DE PARCERIAS E O DESENVOLVIMENTO DE ATIVIDADES CONJUNTAS ENTRE OS PRODUTORES E DEMAIS ATORES DA CADEIA DE PRODUÇÃO

A CONCENTRAÇÃO GEOGRÁFICA DE PRODUTORES E DEMAIS ATORES DA CADEIA DE PRODUÇÃO DE FLORES E PLANTAS ORNAMENTAIS É FUNDAMENTAL PARA O SUCESSO DOS NEGÓCIOS

QUANDO NÃO ESTÃO ATRELADOS A NENHUMA COOPERATIVA, ASSOCIAÇÃO OU AGENTE DISTRIBUIDOR, NA GRANDE MAIORIA DAS VEZES O PRODUTOR NÃO TEM CRITÉRIOS PARA ESCOLHA SEGURA DE SEUS CLIENTES,

COM RELAÇÃO A FATORES COMO PREÇO, PRODUTOS INOVADORES QUALIDADE, CONFIANÇA DE SEUS CLIENTES E A ENTREGA RÁPIDA E PONTUAL, EXISTE ALGUM DELES QUE SE SOBREPONHA EM IMPORTÃNCIA PARA ESSE TIPO DE NEGÓCIO?

AS QUESTÕES AMBIENTAIS (LEGISLAÇÃO, OUTORGA D'ÁGUA, ETC.) INTERFEREM DE ALGUMA MANEIRA NESSE TIPO DE NEGÓCIO? 
QUAIS OS PRINCIPAIS BENEFICIOS DA PARTICIPAÇÃO EM EVENTOS COMO HORTITEC, ENFLOR, EXPLOFLORA, FESTA DO MORANGO E FLORES OU OUTRO DO MESMO GENÊRO?

\subsection{CLIENTES}

COM RELAÇAO AO PERFIL DOS PRINCIPAIS CLIENTES DOS PRODUTORES DESTA ASSOCIAÇÃO são grandes Empresas e/ou produtores

São grandes atacadistas

São grandes supermercados

são pequenas /médias empresas e/ou produtores

SEUS ASSOCIADOS DEPENDEM DRASTICAMENTE DE ALGUNS CLIENTES ESPECÍFICOS

SEUS ASSOCIADOS POSSUEM O MAIOR PODER DE BARGANHA NOS PROCESSOS DE NEGOCIAÇÃO

AONDE SE ENCONTRAM OS PRINCIPAIS CLIENTES DE SEUS ASSOCIADOS?

\subsection{CONCORRENCIA}

AONDE SE ENCONTRAM OS PRINCIPAIS CONCORRENTES DE SEUS ASSOCIADOS?

COM RELAÇAO AO PERFIL DOS PRINCIPAIS CONCORRENTES DOS PRODUTORES DESTA REGIÃO DE PODEMOS DIZER QUE

são grandes Empresas que atuam no mesmo ramo

são pequenos e médias empresas que atuam no mesmo ramo

são as cooperativas do município e/ou região, que eles não são associados

Não existe concorrência para seus associados

\subsection{FINANÇAS}

A ASSOCIAÇAO CONHECE ALGUMA FONTE PÚBLICA DE FINANCIAMENTO

A MAIORIA DOS PRODUTORES QUE TEMOS ACESSO FINANCIAM A EXPANSÃO DA CAPACIDADE PRODUTIVA COM capital próprio,

bancos públicos de investimento,

sistema financeiro internacional

investimento da ASSOCIAÇÃO e/ou cooperativas a que são afiliados

outros

5.5. CAso esta ASSOCIAÇÃo PARTICIPE de ALGUM EVENTO COMO HORTITEC, ENFLOR, EXPLOFLORA, FESTA DO MORANGO E FLORES, OU OUTRO DO MESMO GENÊRO, QUAL(IS) OS MOTIVOS QUE A LEVARAM A TAL PARTICIPAÇÃO?

FACILITA A APROXIMAÇÃO COM OS CLIENTES

ESTE TIPO DE EVENTO TRAZ A POSSIBILIDADE DE CRIAR PARCERIAS E COOPERAÇÃO ATRAVÉS DA MAIOR APROXIMAÇÃO COM OUTRAS EMPRESAS

ESTE TIPO DE EVENTO TRAZ PROMOVE MAIOR ACESSO AO MERCADO CONSUMIDOR

ESTE TIPO DE EVENTO PROMOVE A ABERTURA DE NOVOS NEGÓCIOS

ESTE TIPO DE EVENTO TRAZ A POSSIBILIDADE PARA CONHECIMENTO DO QUE ESTÁ SENDO OFERECIDO PELA CONCORRÊNCIA

ESTE TIPO DE EVENTO FACILITA A DIFUSÃO DA MARCA E/OU PRODUTO

ESTE TIPO DE EVENTO FAVORECE O CONHECIMENTO DAS NECESSIDADES DOS CLIENTES

OUTRO. (ESPECIFICAR, POR FAVOR) 


\section{ROTEIRO DE ENTREVISTAS - ENTIDADES DE APOIO}

\section{BLOCO 1 - CARACTERIZAÇÃO}

\subsection{DADOS DO RESPONDENTE}

NOME

CARGO / FUNÇÃO ENTIDADE

TELEFONE PARA CONTATO:

E-MAIL:

\subsection{A ENTIDADE}

\subsubsection{DADOS GERAIS}

\begin{tabular}{|l|l|}
\hline Nome & \\
\hline Município: & Ano de inicio das atividades: \\
\hline Telefone: & Fax: \\
\hline Caráter Jurídico: PÚBLICA $\square-$ MISTA & - \\
\hline E-mail: &
\end{tabular}

\subsubsection{CARÁTER DE ATUAÇÃO}

\begin{tabular}{|l|l|l|}
\hline Financeira & Pesquisa e Desenvolvimento Tecnológico & \\
\hline Sindicato Trabalhadores & Pesquisa e Desenvolvimento Científico & \\
\hline Sindicato Patronal & Apoio de Gestão Empresarial & \\
\hline Capacitação Profissional de Empregados & Apoio Técnico & \\
\hline Associação Comercial e Empresarial & Associação de Estudos Técnicos e de Mercado & \\
\hline Associação Patronal & Outros (favor especificar) & \\
\hline
\end{tabular}

1.2.3. QUAL (QUAIS) DOS SEGMENTOS ABAIXO QUE SEUS ESTA ASSOCIAÇÃO ATUA PRIORIARIAMENTE

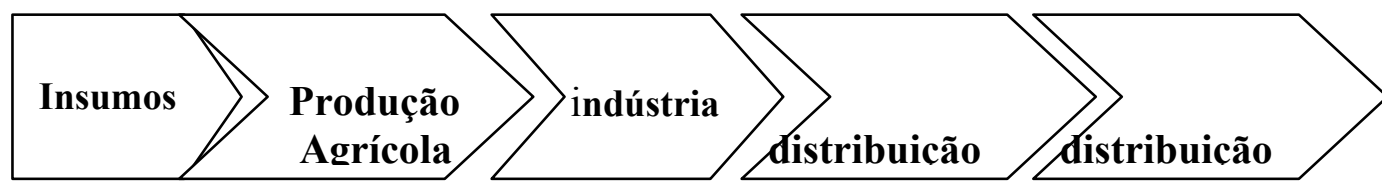

Consumidor Final

1.2.4. QUAIS AS ÁREAS (REGIÃO) DE ATUAÇÃo DESTA ENTIDADE (NO CASO DE ENTIDADES COMO SEBA SENAR, ETC. POR FAVOR CONSIDERE A AERA DE ATUAÇÃO DE SUA UNIDADE/ESCRITÓRIO)

\subsubsection{CASO ESTA ENTIDADE ESTEJA DESENVOLVENDO ALGUMA ATIVIDADE ESPECIFICA EM RELAÇÃO A} FLORICULTURA FAVOR ESPECIFICAR EM QUE MUNICIPIO(S) E QUAL A ATIVIDADE. INCLUÍ-SE ATIVIDADES DESENVOLVIDAS EM PARCERIAS COM OUTRAS ENTIDADES

\subsection{PAPEL DA ENTIDADE}

ESTA ENTIDADE ESTABELECE CONTATO FREQÜENTE COM TÉCNICOS DA CATI, AUXILIANDO NO DESEMPENHO DAS ATIVIDADES PRODUTIVAS DE NOSSOS ASSOCIADOS .

ESTA ENTIDADE INCENTIVA AS AÇÕES DE PARCERIA ENTRE OS ATORES DA CADEIA DE FLORES

ESTA ENTIDADE ATUA NO DESENVOLVIMENTO DE INOVAÇÕES DE PRODUTOS

DESENVOLVEMOS PESQUISAS FREQÜENTES COM O IAC E A EMBRAPA

DESENVOLVE FREQÜENTES PESQUISAS TÉCNICAS DA ÁREA DE PRODUÇÃO E CULTIVO

ESTA ENTIDADE É ATUANTE NO SENTIDO DE PROMOVER O DESENVOLVIMENTO DOS AGRONEGÓCIOS DE FLORES DE SEUS ASSOCIADOS

ESTA ENTIDADE É ATUANTE NO SENTIDO DE PROMOVER AÇÕES DE PARCERIA ENTRE SEUS ASSOCIADOS

ESTA ENTIDADE AUXILIA SIGNIFICATIVA NA CONSTRUÇÃO DE POLITICAS PÚBLICAS PARA O SETOR 
1.4. QUAIS SERVIÇOS QUE OS PRODUTORES BUSCAM NESTA ENTIDADE E COM QUE FREQÜÊNCIA.

\begin{tabular}{|l|l|l|l|}
\hline \multicolumn{1}{|c|}{ Serviço } & $\begin{array}{c}\text { Nenhuma } \\
\text { freqüência }\end{array}$ & Pouca freqüência & $\begin{array}{c}\text { Muita } \\
\text { freqüência }\end{array}$ \\
\hline Comercialização de produtos & & & \\
\hline Compra de insumos & & & \\
\hline Consorcio de Exportação & & & \\
\hline Participação em feiras e eventos & & & \\
\hline Assessoria jurídica & & & \\
\hline Assessoria administrativa & & & \\
\hline Informações sobre outras Empresas/ASSOCIAÇAO s & & & \\
\hline Informações de mercado & & & \\
\hline Boletins de informação & & & \\
\hline Novas Variedades & & & \\
\hline Assessoria tecnológica de produção e armazenamento & & & \\
\hline Capacitação de mão-de-obra & & & \\
\hline Cursos e seminários para o produtor & & & \\
\hline Acesso/conhecimento de novas tecnologias & & & \\
\hline Acesso/conhecimento de linhas de crédito & & & \\
\hline Outros(favor especificar) & & & \\
\hline
\end{tabular}

\section{BLOCO 2 -COOPERAÇÃO/PARCERIA}

2.1 Estabeleceu AÇões de COOPERAÇÃo e/OU PARCERIAS COM OUTROS PRODUtORES, FORNECEDORES, CLIENTES E/OU OUTRAS EMPRESAS QUE ATUAM EM SUA MESMA ÁREA DE NEGÓCIOS?

2.2. QUAIS OS PRINCIPAIS MOTIVOS DAS AÇÕES DE PARCERIA QUE FORAM DESENVOLVIDAS PELOS SES ASSOCIADOS/PRODUTORES E COM QUAL FREQUENCIA?

\begin{tabular}{|l|l|l|l|l|}
\hline \multicolumn{2}{|c|}{ Cooperação/Parceria } & \multicolumn{3}{c|}{ FREQÜẾNCIA } \\
\hline & Nenhuma & Alta & Mediana & Baixa \\
\hline $\begin{array}{l}\text { Outros produtores rurais que cultivam as mesmas } \\
\text { espécies que são cultivadas em sua propriedade }\end{array}$ & & & & \\
\hline $\begin{array}{l}\text { Outros produtores rurais que cultivam as outras espécies } \\
\text { que são cultivadas em sua propriedade }\end{array}$ & & & & \\
\hline Clientes situados no Brasil & & & & \\
\hline Clientes situados no Exterior & & & & \\
\hline SEBRAE & & & & \\
\hline SENAR & & & & \\
\hline Entidades de pesquisa (IAC, EMBRAPA, etc.) & & & \\
\hline Casa da Agricultura-CATI & & & & \\
\hline Esta associação não tem essa informação & & & & \\
\hline Outros (favor especificar) & & & & \\
\hline
\end{tabular}

2.3. CASO ESTA ENTIDADE TENHA IDENTIFICADO ALGUM TIPO DE PARCERIA NA QUESTÃO ANTERIOR, POR FAVOR, QUAIS OS PRINCIPAIS MOTIVO QUE LEVARAM SEUS ASSOCIADOS A DESENVOLVEREM TAIS AÇÕES DE COOPERAÇÃO OU PARCERIA.

COMPARTILHAR INSTALAÇÕES DE PRODUÇÃO

COMPARTILHAR A UTILIZAÇÃO DE EQUIPAMENTOS DE PRODUÇÃO, ESTUFAS, ETC.

COMPARTILHAR INSTALAÇÕES DE PESQUISA

PARTICIPAÇÃO CONJUNTA EM FEIRAS (NACIONAIS E/OU INTERNACIONAIS), EXPOSIÇÕES, ETC.

COMPARTILHAR A ESTRUTURA DE VENDAS (CANAIS, PROPAGANDA, MARCA, ETC.)

COMPRAS CONJUNTAS DE INSUMOS E EQUIPAMENTOS

PARTICIPAÇÃO EM CONSÓRCIOS DE EXPORTAÇÃO

COMPARTILHAMENTO DE IDÉIAS E INFORMAÇÕES (TÉCNICAS, ORGANIZACIONAIS, ETC), NOVIDADES

TECNOLÓGICAS,

DESENVOLVIMENTO OU MELHORIA DE INSUMOS, PRODUTOS OU PROCESSOS DE PRODUÇÃO

TREINAMENTO DE PESSOAL - CURSOS - DIA DE CAMPO 
CAPACITAÇÃO PARA ATENDER AOS REQUISITOS DO PRODUTO IMPOSTOS PELO CLIENTE CAPACITAÇÃO PARA ATENDER AOS REQUISITOS DO PRODUTO IMPOSTOS PELO FORNECEDOR ACESSO À TECNOLOGIA OUTROS

\section{4." A MAIORIA DAS AÇÕES DE PARCERIAS E/OU COOPERAÇÃO DESENVOLVIDA POR PELOS PRODUTORES QUE ESTA ENTIDADE TEM CONTACTO, SURGIU...."}

ATRAVÉS DE LAÇOS FAMILIARES.

CONVÍVIO COM OUTROS MEMBROS DESTA ENTIDADE E/OU ASSOCIAÇÃO DE PRODUTORES.

COMUNIDADE ÉTNICA DA QUAL SÃO DESCENDENTES

CONSOLIDAÇÃO DAS RELAÇÕES COMERCIAIS/NEGÓCIO, COM O TEMPO

PELO INCENTIVO/INTERMEDIAÇÃO DO SINDICATO PATRONAL, E/OU SINDICATO DE TRABALHADORES; ENTIDADES COMO SEBRAE, SENAR, ASSOCIAÇÃO COMERCIAL LOCAL; ETC.

INDEPENDENTEMENTE DE LAÇOS CULTURAIS E/OU DE ASCENDÊNCIA ESTRANGEIRA, FORAM ESTABELECIDAS TAIS AÇÕES POR QUE SEI DA IMPORTÂNCIA DELAS PARA O FORTALECIMENTO DA ESTRUTURA DE PRODUÇÃO E/OU COMERCIALIZAÇÃO DA QUAL DEPENDEM SEUS ASSOCIADOS.

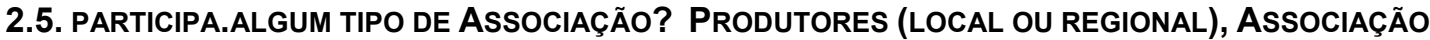
COMERCIAL LOCAL OU ASSOCIAÇÕES LOCAIS RELACIONADAS A OUTROS FINS, NÃO VOLTADAS AO DESENVOLVIMENTO DE SEUS NEGÓCIOS

2.6. EM CASO AFIRMATIVO DA QUESTÃo ANTERIOR, ESPECIFIQUE QUAIS SERVIÇOS ESTA ENTIDADE SE UTILIZA DAS ASSOCIAÇÕES DA QUAL É FILIADA E COM QUAL FREQÜÊNCIA

\begin{tabular}{|l|l|l|l|}
\hline \multicolumn{1}{|c|}{ Serviço } & $\begin{array}{c}\text { Nenhuma } \\
\text { freqüência }\end{array}$ & Pouca freqüência & $\begin{array}{c}\text { Muita } \\
\text { freqüência }\end{array}$ \\
\hline Comercialização de produtos & & & \\
\hline Compra de insumos & & & \\
\hline Consorcio de Exportação & & & \\
\hline Participação em feiras e eventos & & & \\
\hline Assessoria jurídica & & & \\
\hline Assessoria administrativa & & & \\
\hline Informações sobre outras Empresas/Cooperativas & & & \\
\hline Informações de mercado & & & \\
\hline Boletins de informação & & & \\
\hline Lobby & & & \\
\hline Capacitação de mão-de-obra & & & \\
\hline Cursos e seminários para o produtor & & & \\
\hline Acesso/conhecimento de novas tecnologias & & & \\
\hline Acesso/conhecimento de linhas de crédito & & \\
\hline Outros (favor especificar) & & \\
\hline
\end{tabular}


2.7. Caso ESTA ENTIDADE tenha estabelecido PARCERIAS COM OUTROS PRODUTORES, CLIENTES, FORNECEDORES OU OUTRAS EMPRESAS QUE ATUEM NO SETOR DE AGRONEGÓCIOS DE FLORES E PLANTASPOR FAVOR, ESPECIFIQUE O(S) MOTIVO(S QUE O LEVARAM A TAL ATITUDE.

\begin{tabular}{|l|l|}
\hline \multicolumn{1}{|c|}{ Motivos promotores das Ações Conjuntas/ Parcerias } & \\
\hline Compartilhar instalações de produção & \\
\hline Compartilhar a utilização de equipamentos de produção, estufas, etc. & \\
\hline Compartilhar instalações de pesquisa & \\
\hline Participação conjunta em feiras (nacionais e/ou internacionais), exposições, etc. & \\
\hline Compartilhar a estrutura de vendas (canais, propaganda, marca, etc.) & \\
\hline Compras conjuntas de insumos e equipamentos & \\
\hline Participação em consórcios de exportação & \\
\hline $\begin{array}{l}\text { Compartilhamento de idéias e informações (técnicas, organizacionais, etc), novidades } \\
\text { tecnológicas, }\end{array}$ & \\
\hline Desenvolvimento ou melhoria de insumos, produtos ou processos de produção & \\
\hline Treinamento de pessoal - cursos - dia de campo & \\
\hline Capacitação para atender aos requisitos do produto impostos pelo cliente & \\
\hline Capacitação para atender aos requisitos do produto impostos pelo fornecedor & \\
\hline Acesso à tecnologia & \\
\hline Outros (favor especificar): & \\
\hline
\end{tabular}

2.8. QUANTO AO(S) MOTIVO(S) QUE OS LEVARAM A DESENVOLVEREM TAIS AÇÕES DE COOPERAÇÃo OU PARCERIA.

\begin{tabular}{|l|l|}
\hline \multicolumn{1}{|c|}{ Motivos promotores das Ações Conjuntas/ Parcerias } & \\
\hline Compartilhar instalações de produção & \\
\hline Compartilhar a utilização de equipamentos de produção, estufas, etc. & \\
\hline Compartilhar instalações de pesquisa & \\
\hline Participação conjunta em feiras (nacionais e/ou internacionais), exposições, etc. & \\
\hline Compartilhar a estrutura de vendas (canais, propaganda, marca, etc.) & \\
\hline Compras conjuntas de insumos e equipamentos & \\
\hline Participação em consórcios de exportação & \\
\hline $\begin{array}{l}\text { Compartilhamento de idéias e informações (técnicas, organizacionais, etc), novidades } \\
\text { tecnológicas, }\end{array}$ & \\
\hline Desenvolvimento ou melhoria de insumos, produtos ou processos de produção & \\
\hline Treinamento de pessoal - cursos - dia de campo & \\
\hline Capacitação para atender aos requisitos do produto impostos pelo cliente & \\
\hline Capacitação para atender aos requisitos do produto impostos pelo fornecedor & \\
\hline Acesso à tecnologia & \\
\hline Outros (favor especificar): & \\
\hline
\end{tabular}

2.9 O FORTE TRAÇO ÉTNICO-CULTURAL, POR EXEMPLO ORIENTAIS OU HOLANDESES (OU SEUS DESCENDENTES) FACILITA MUITO O DESENVOLVIMENTO PARCERIAS E AUMENTA A CONFIANÇA MÚTUA.

\section{BLOCO 3- LOCALIDADE}

EM TERMOS GERAIS, QUAL É A REGIÃO DE MAIS IMPORTANTE PARA OS AGRONEGÓCIOS DE FLORES E PLANTAS no Estado de SÃo Paulo: Holambra, Mogi das Cruzes, Atibaia ou Registro?

O MUNICÍPIO (REGIÃO) DE HOLAMBRA/MOGI DAS CRUZES POSSIBILITA MELHORES CONDIÇÕES PARA O DESEMPENHO DOS NEGÓCIOS DE FLORES, SE COMPARADO À OUTROS MUNICÍPIOS E/OU REGIÕES DO BRASIL 
A GERAÇÃO DE CONHECIMENTO REFERENTE A TECNOLOGIA DE PRODUÇÃO E COMERCIALIZAÇÃO DE FLORES E PLANTAS É UM DOS PRINCIPAIS FATORES DE SUCESSO PARA A OS AGRONEGÓCIOS DE FLORES E PLANTAS ORNAMENTAIS? ESSA GERAÇÃO ESTÁ CONCENTRRADA PRIORITARIAMENTE CONCENTRADA NO MUNICÍPIO DE HOLAMBRA E REGIÃO?

O MUNICÍPIO DE HOLAMBRA E REGIÃO É A ÁREA MAIS IMPORTANTE DOS AGRONEGÓCIOS DE PLANTAS E FLORES DO BRASIL, NO TOCANTE AO PROCESSO DE COMERCIALIZAÇÃO

AONDE SE CONCENTRA PRIORIRATRIAMENTE A GERAÇÃO DE CONHECIMENTO E TECNOLOGIA RELACIONADA AOS AGRONEGÓCIOS DE FLORES E PLANTAS NO BRASIL? ESTÁ CONCENTRADA NOS CENTROS DE PESQSUISA AGROPECUÁRIOS, COMO EMBRAPA E IAC OU ESTÁ CONCENTRADA NAS EMPRESAS PRIVADAS DE INSUMOS E MAQUINÁRIOS?

O GOVERNO LOCAL É ATUANTE NO SENTIDO DE PROMOVER O DESENVOLVIMENTO DOS AGRONEGÓCIOS DE FLORES NA REGIÃO?

OS RESULTADOS DE DESEMPENHO DE NEGÓCIOS DE SEUS ASSOCIADOS SÃO SUPERIORES AQUELES QUE PODERIAM SER OBSERVADOS SE ESTIVESSEM LOCALIZADOS EM OUTRA REGIÃO?

QUAIS AS PRINCIPAIS VANTAGENS QUE A LOCALIZAÇÃO DE SEUS ASSOCIADOS NO MUNICÍPIO DE HOLAMBRA E REGIÃO QUE ESTA ASSOCIAÇÃO PODE IDENTIFICAR?

Melhor acesso à matéria-prima, infra-estrutura e assistência técnica

Possibilidade de criar parcerias

Maior acesso ao mercado consumidor

Aproximação com outros produtores possibilitando desenvolvimento de novos produtos e/ou novas técnicas de produção

Disponibilidade de mão-de-obra e treinamento

Apoio de entidades, associações de classe, SENAR, SEBRAE, associação comercial, etc.

Dificulta a entrada de novos atores que não tenham nenhum vínculo com a localidade, devido a dificuldade de aceitação dos mesmos por parte do grupo de atores local

Facilita a comercialização e distribuição dos produtos

Ser beneficiado por estar inserido num pólo de excelência na produção e comercialização de flores e plantas

Nestes municípios é que se concentram os melhores especialistas e infra-estrutura em comercialização e produção de flores do país

ESTE MUNICIPIO/REGIÃO PODE SER CONSIDERADO COMO UM PÓLO DE EXCELÊNCIA EM CULTIVO PROTEGIDO

QUAIS AS PRINCIPAIS DESVANTAGENS QUE A LOCALIZAÇÃO DE SEUS ASSOCIADOS NESTE MUNICÍPIO/NESTA REGIÃO O QUE ESTA ASSOCIAÇÃO PODE IDENTIFICAR?

Contribui para a saturação das possibilidades de produção local

Aumento das rivalidades e conflitos entre os concorrentes

Pressiona os custos com infra-estrutura para cima

Pressiona os salários para cima

Problemas de circulação - trânsito

Acelera ao desgaste da infra-estrutura local

Acaba por atrair produtores de outras regiões, principalmente para a comercialização de seus

produtos, e isso vai deteriorando as fortes relações entre os produtores locais

Dificuldades em distribuir os produtos pela saturação dos distribuidores locais

Outras

COM RELAÇÃO À PERCEPÇÃO DE COMO OS PROFISSIONAIS DOS AGRONEGÓCIOS, RECONHECEM ESTE MUNICÍPO E REGIÃO. PODEMOS AFIRMAR QUE TAL RECONHECIMENTO SE DÁ...

pela produção de flores

pelo comércio de flores

pelos agronegócios em geral

pelo turismo relacionado a flores e as tradições culturais

pela fruticultura

pela cultura de hortaliças

devido a produção animal (suinocultura, aves de postura e/ou corte)

pela excelência tecnológica em cultivo protegido (estufa)

Por outros motivos (por favor, especifique) 


\section{BLOCO 4 - INOVAÇÃO/INFORMAÇÕES}

4.1. IDENTIFIQUE A(S) FONTE(S) DE INFORMAÇÃo (ÕES) MAIS IMPORTATES, PARA GERAR NOVOS CONHECIMENTOS PARA O DESENVOLVIMENTO DOS NEGÓCIOS DESTA

\section{FONTE}

Conversas informais

Entidades de apoio (SEBRAE, SENAR, centros de tecnologia)

Fornecedor de maquinário

Feiras e eventos similares

Dia de Campo

Entidades de classe (sindicatos, associações comerciais, e etc.)

Publicações especializadas

Visitas a outras empresas e/ou propriedades da região

Clientes

Vendedores

Empresas do exterior que tenho contato freqüente

\section{FONTE}

Visitas a empresas e/ou propriedades de fora da região

Funcionários que trabalharam em outras empresas ou propriedades

Consultores especializados da região

Consultores especializados de outras regiões

Revistas especializadas

Serviços da ASSOCIAÇAO e/ou associação

da qual sou filiado

$\mathrm{Na}$ troca de informações com outros

produtores

Vendedores e técnicos das empresas de insumo e/ou infra-estrutura

Assistência técnica governamental

Assistência técnica privada

Outras: (especificar, por favor)

4.2. QUANTO À ORIGEM DAS INOVAÇÕES TECNOLÓGICAS DE SEUS ASSOCIADOS

\begin{tabular}{|l|l|l|l|l|l|}
\hline & Sempre & $\begin{array}{c}\text { Na } \\
\text { maioria } \\
\text { das vezes }\end{array}$ & Raramente & Nunca & Não Sabe \\
\hline $\begin{array}{l}\text { Estão embutidas nas máquinas compradas no } \\
\text { mercado nacional }\end{array}$ & & & & & \\
\hline $\begin{array}{l}\text { Estão embutidas nas máquinas compradas no } \\
\text { mercado internacional }\end{array}$ & & & & & \\
\hline $\begin{array}{l}\text { São desenvolvidas internamente nas } \\
\text { propriedades }\end{array}$ & & & & & \\
\hline São adaptadas internamente nas propriedades & & & & & \\
\hline $\begin{array}{l}\text { São desenvolvidas em cooperação com } \\
\text { fornecedores }\end{array}$ & & & & & \\
\hline São geradas por fornecedores estrangeiros & & & & & \\
\hline São geradas por fornecedores domésticos/locais & & & & & \\
\hline São geradas por clientes estrangeiros & & & & & \\
\hline São geradas por fornecedores locais/domésticos & & & & & \\
\hline São desenvolvidas em cooperação com clientes & & & & & \\
\hline $\begin{array}{l}\text { São desenvolvidas em cooperação com outras } \\
\text { empresas locais }\end{array}$ & & & & & \\
\hline Outra Origem especificar) & & & & & \\
\hline
\end{tabular}

4.3. IDENTIFIQUE O(S) FATORE(S) QUE PODE(M) SER RELACIONADO(S) A INOVAÇÃO NO CONTEXTO DOS AGRONEGÓCIOS DE FLORES E PLANTAS

\section{FONTE FONTE}

Variedades, cultivares, etc

Técnicas de cultivo

Técnicas de armazenagem

Adaptação de espécies às

coindições locais de cultivo

Desenvolvimento de Máquinas e

Equipamentos

Selos de origem e/ou qualidade

Outros (por favor, especificar)

Desenvolvimento de Embalagens para produto final (flores e plantas)

Veiling

Técnicas de adubação e controle fitossanitário

Comercialização

Processos administrativos da propriedade rural

Marca própria 


\section{BLOCO 5-BLOCO 5 - GESTÃO / ESTRATÉGIAS DE}

\subsection{Com Relação Visão Geral Dos Agronegócios de flores no Estado de São Paulo}

A FALTA DE POLÍTICAS PÚBLICAS PARA O SETOR INTERFERE DE FORMA SIGNIFICATIVA E NEGATIVAMENTE NO DESEMPENHO DOS AGRONEGÓCIOS DE FLORES

O DESCONHECIMENTO DE FONTES DE FINANCIAMENTO, POR PARTE DOS PRODUTORES, É UM DOS PRINCIPAIS FATORES QUE PREJUDICAM UM MELHOR DESEMPENHO DOS NEGÓCIOS DE FLORES

A ALTA BUROCRACIA E EXIGÊNCIAS PARA OBTENÇÃO DE FINANCIAMENTOS, É UM DOS PRINCIPAIS FATORES QUE PREJUDICAM UM MELHOR DESEMPENHO DOS NEGÓCIOS DE FLORES

O COOPERATIVISMO E/OU ASSOCIATIVISMO É UM FATOR ESSENCIAL PARA O SUCESSO DOS AGRONEGÓCIOS DE FLORES E PLANTAS ORNAMENTAIS

A IDENTIDADE ÉTNICA E CULTURAL FAVORECEM AS RELAÇÕES DE PARCERIAS E O DESENVOLVIMENTO DE ATIVIDADES CONJUNTAS ENTRE OS PRODUTORES E DEMAIS ATORES DA CADEIA DE PRODUÇÃO

A CONCENTRAÇÃO GEOGRÁFICA DE PRODUTORES E DEMAIS ATORES DA CADEIA DE PRODUÇÃO DE FLORES E PLANTAS ORNAMENTAIS É FUNDAMENTAL PARA O SUCESSO DOS NEGÓCIOS

COM RELAÇÃO A FATORES COMO PREÇO, PRODUTOS INOVADORES QUALIDADE, CONFIANÇA DE SEUS CLIENTES E A ENTREGA RÁPIDA E PONTUAL, EXISTE ALGUM DELES QUE SE SOBREPONHA EM IMPORTÃNCIA PARA ESSE TIPO DE NEGÓCIO?

As QUESTÕES AMBIENTAIS (LEGISLAÇÃO, OUTORGA D'ÁGUA, ETC.) INTERFEREM DE ALGUMA MANEIRA NESSE TIPO DE NEGÓCIO?

QUAIS OS PRINCIPAIS BENEFICIOS DA PARTICIPAÇÃO EM EVENTOS COMO HORTITEC, ENFLOR, EXPLOFLORA, FESTA DO MORANGO E FLORES OU OUTRO DO MESMO GENÊRO?

\subsection{CLIENTES}

COM RELAÇAO AO PERFIL DOS PRINCIPAIS CLIENTES DOS PRODUTORES DESTA ASSOCIAÇÃO

são grandes Empresas e/ou produtores

São grandes atacadistas

São grandes supermercados

são pequenas /médias empresas e/ou produtores

SEUS ASSOCIADOS DEPENDEM DRASTICAMENTE DE ALGUNS CLIENTES ESPECÍFICOS

SEUS ASSOCIADOS POSSUEM O MAIOR PODER DE BARGANHA NOS PROCESSOS DE NEGOCIAÇÃO

AONDE SE ENCONTRAM OS PRINCIPAIS CLIENTES DE SEUS ASSOCIADOS?

\subsection{CONCORRENCIA}

AONDE SE ENCONTRAM OS PRINCIPAIS CONCORRENTES DE SEUS ASSOCIADOS?

COM RELAÇAO AO PERFIL DOS PRINCIPAIS CONCORRENTES DOS PRODUTORES DESTA REGIÃO DE PODEMOS DIZER QUE

são grandes Empresas que atuam no mesmo ramo

são pequenos e médias empresas que atuam no mesmo ramo

são as cooperativas do município e/ou região, que eles não são associados

Não existe concorrência para seus associados

\subsection{FINANÇAS}

A ASSOCIAÇAO CONHECE ALGUMA FONTE PÚBLICA DE FINANCIAMENTO

A MAIORIA DOS PRODUTORES QUE TEMOS ACESSO FINANCIAM A EXPANSÃO DA CAPACIDADE PRODUTIVA COM capital próprio, bancos públicos de investimento, sistema financeiro internacional investimento da ASSOCIAÇÃO e/ou cooperativas a que são afiliados outros 
5.5. CAso esta entidade PARTICIPE de algum eVento como HORTITEC, ENFLOR, EXPLOFLORA, FESTA DO MORANGO E FLORES, OU OUTRO DO MESMO GENÊRO, QUAL(IS) OS MOTIVOS QUE A LEVARAM A TAL PARTICIPAÇÃO?

FACILITA A APROXIMAÇÃO COM OS CLIENTES

ESTE TIPO DE EVENTO TRAZ A POSSIBILIDADE DE CRIAR PARCERIAS E COOPERAÇÃO ATRAVÉS DA MAIOR APROXIMAÇÃO COM OUTRAS EMPRESAS

ESTE TIPO DE EVENTO TRAZ PROMOVE MAIOR ACESSO AO MERCADO CONSUMIDOR

ESTE TIPO DE EVENTO PROMOVE A ABERTURA DE NOVOS NEGÓCIOS

ESTE TIPO DE EVENTO TRAZ A POSSIBILIDADE PARA CONHECIMENTO DO QUE ESTÁ SENDO OFERECIDO PELA CONCORREANCIA

ESTE TIPO DE EVENTO FACILITA A DIFUSÃO DA MARCA E/OU PRODUTO

ESTE TIPO DE EVENTO FAVORECE O CONHECIMENTO DAS NECESSIDADES DOS CLIENTES

OUTRO. (ESPECIFICAR, POR FAVOR) 


\section{ROTEIRO DE ENTREVISTAS - COOPERATIVAS}

\section{BLOCO 1 - CARACTERIZAÇÃO}

\subsection{DADOS DO RESPONDENTE}

NOME:

CARGO / FUNÇÃO NA COOPERATIVA

TELEFONE PARA CONTATO:

E-MAIL:

\subsection{A COOPERATIVA}

\subsubsection{DADOS GERAIS}

\begin{tabular}{|l|l|l|}
\hline Nome & \multicolumn{2}{|l|}{ Faturamento Anual (aproximado): $\mathrm{R} \$$} \\
\hline Telefone: & \multicolumn{1}{|l|}{$\mathrm{N}^{\circ}$ de Cooperados } \\
\hline No. Empregados Fixos: & No. Empregados Temporários /ano (aproximado): \\
\hline Ano de inicio aproximado nas atividades agrícolas: & Ano de inicio na floricultura \\
\hline
\end{tabular}

\subsubsection{ASSINALE EM QUAL DOS SEGMENTOS ABAIXO QUE ESTA COOERATIVA ATUA.}

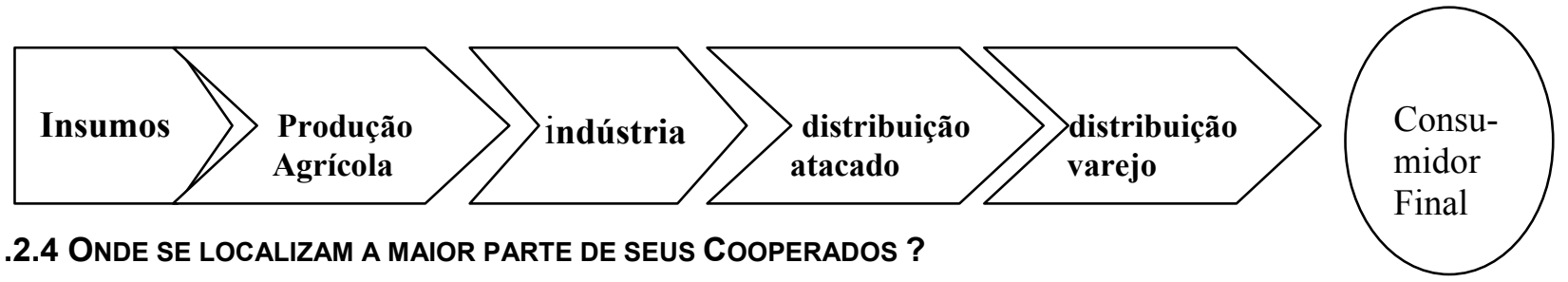

\subsection{PAPEL DA COOPERATIVA}

É ATUANTE NO SENTIDO DE PROMOVER O DESENVOLVIMENTO DOS AGRONEGÓCIOS DE FLORES DE SEUS COOPERADOS

A CAPACITAÇÃO GERENCIAL DE NOSSO COOPERADOS É ALVO FREQÜENTE DE PREOCUPAÇÃO DESTA COOPERATIVA

DIVULGA COM FREQÜÊNCIA OS AGENTES E AS LINHAS DE FINANCIAMENTOS DISPONIVEIS.

É ATUANTE NO SENTIDO DE PROMOVER A CONSTANTE ATUALIZAÇÃO TECNOLÓGICA DE SEUS COOPERADOS, ATRAVÉS DE ASSISTÊNCIA TÉCNICA PRÓPRIA

É ATUANTE NO SENTIDO DE PROMOVER A PARTICIPAÇÃO DE SEUS COOPERADOS EM FEIRAS E EVENTOS RELACIONADOS AOS SEUS NEGÓCIOS

ESTABELECE OS PREÇOS DE VENDA E AS CONDIÇÕES PARA RECEBIMENTO DAS VENDAS POR PARTE DE SEUS COOPERADOS

ESTREITA OS LAÇOS DE RELACIONAMENTO E CONFIANÇA ENTRE OS PRODUTORES

PROMOVE COM FREQÜENNCIA O TREINAMENTO/ CAPACITAÇÃO DOS PRODUTORES E/OU SEUS EMPREGADOS

DISTRIBUI E COMERCIALIZA SEUS PRODUTOS DE MANEIRA MAIS EFICIENTE DO QUE SE O PRODUTOR FIZESSE ISSO SOZINHO

DESENVOLVE PESQUISAS FREQÜENTES COM O IAC E A EMBRAPA

ESTABELECE CONTATO FREQÜENTE COM TÉCNICOS DA CATI, AUXILIANDO NO DESEMPENHO DAS ATIVIDADES PRODUTIVAS DE NOSSOS COOPERADOS.

O COOPERATIVISMO E/OU ASSOCIATIVISMO É FUNDAMENTAL PARA O BOM DESEMPENHO DE MEUS NEGÓCIOS (FLORES E PLANTAS) NESTA REGIÃO

FORNECE FREQÜENTES INFORMAÇÕES POR PARTE DA(S) COOPERATIVA (S) E DEMAIS ORGANISMOS COMO SEBRAE, ASSOCIAÇÃO COMERCIAL, ETC. SOBRE LINHAS DE FINANCIAMENTO DISPONIVEIS 
1.4. QUAIS SERVIÇOS QUE OS PRODUTORES BUSCAM NESTA COOPERATIVA E COM QUE FREQÜÊNCIA?

\begin{tabular}{|l|l|l|l|}
\hline \multicolumn{1}{|c|}{ Serviço } & $\begin{array}{c}\text { Nenhuma } \\
\text { freqüência }\end{array}$ & Pouca freqüência & $\begin{array}{c}\text { Muita } \\
\text { freqüência }\end{array}$ \\
\hline Comercialização de produtos & & & \\
\hline Compra de insumos & & & \\
\hline Consorcio de Exportação & & & \\
\hline Participação em feiras e eventos & & & \\
\hline Assessoria jurídica & & & \\
\hline Assessoria administrativa & & & \\
\hline Informações sobre outras Empresas/ASSOCIAÇAO s & & & \\
\hline Informações de mercado & & & \\
\hline Boletins de informação & & & \\
\hline Novas Variedades & & & \\
\hline Assessoria tecnológica de produção e armazenamento & & & \\
\hline Capacitação de mão-de-obra & & & \\
\hline Cursos e seminários para o produtor & & & \\
\hline Acesso/conhecimento de novas tecnologias & & & \\
\hline Acesso/conhecimento de linhas de crédito & & & \\
\hline Outros(favor especificar) & & \\
\hline
\end{tabular}

\section{BLOCO 2-COOPERAÇÃO/PARCERIA}

2.1 Estabeleceu AÇÕES DE COOPERAÇÃo E/OU PARCERIAS COM OUTROS PRODUTORES, FORNECEDORES, CLIENTES E/OU OUTRAS EMPRESAS QUE ATUAM EM SUA MESMA ÁREA DE NEGÓCIOS?

2.2. QUAIS OS PRINCIPAIS MOTIVOS DAS AÇÕES DE PARCERIA QUE FORAM DESENVOLVIDAS PELOS SES ASSOCIADOS E COM QUAL FREQUENCIA?

\begin{tabular}{|l|l|l|l|l|}
\hline \multicolumn{2}{|c|}{ Cooperação/Parceria } & \multicolumn{3}{c|}{ FREQÜÊNCIA } \\
\cline { 2 - 4 } & Nenhuma & Alta & Mediana & Baixa \\
\hline $\begin{array}{l}\text { Outros produtores rurais que cultivam as mesmas } \\
\text { espécies que são cultivadas em sua propriedade }\end{array}$ & & & & \\
\hline $\begin{array}{l}\text { Outros produtores rurais que cultivam as outras espécies } \\
\text { que são cultivadas em sua propriedade }\end{array}$ & & & & \\
\hline Clientes situados no Brasil & & & & \\
\hline Clientes situados no Exterior & & & & \\
\hline SEBRAE & & & & \\
\hline SENAR & & & & \\
\hline Entidades de pesquisa (IAC, EMBRAPA, etc.) & & & & \\
\hline Casa da Agricultura-CATI & & & & \\
\hline Esta associação não tem essa informação & & & & \\
\hline Outros (favor especificar) & & & & \\
\hline
\end{tabular}

2.3. CASO ESTA ENTIDADE TENHA IDENTIFICADO ALGUM TIPO DE PARCERIA NA QUESTÃO ANTERIOR, POR FAVOR, QUAIS OS PRINCIPAIS MOTIVO QUE LEVARAM SEUS ASSOCIADOS A DESENVOLVEREM TAIS AÇÕES DE COOPERAÇÃO OU PARCERIA.

COMPARTILHAR INSTALAÇÕES DE PRODUÇÃO

COMPARTILHAR A UTILIZAÇÃO DE EQUIPAMENTOS DE PRODUÇÃO, ESTUFAS, ETC.

COMPARTILHAR INSTALAÇÕES DE PESQUISA

PARTICIPAÇÃO CONJUNTA EM FEIRAS (NACIONAIS E/OU INTERNACIONAIS), EXPOSIÇÕES, ETC.

COMPARTILHAR A ESTRUTURA DE VENDAS (CANAIS, PROPAGANDA, MARCA, ETC.)

COMPRAS CONJUNTAS DE INSUMOS E EQUIPAMENTOS

PARTICIPAÇÃO EM CONSÓRCIOS DE EXPORTAÇÃO

COMPARTILHAMENTO DE IDÉIAS E INFORMAÇÕES (TÉCNICAS, ORGANIZACIONAIS, ETC), NOVIDADES

TECNOLÓGICAS,

DESENVOLVIMENTO OU MELHORIA DE INSUMOS, PRODUTOS OU PROCESSOS DE PRODUÇÃO

TREINAMENTO DE PESSOAL - CURSOS - DIA DE CAMPO

CAPACITAÇÃO PARA ATENDER AOS REQUISITOS DO PRODUTO IMPOSTOS PELO CLIENTE

CAPACITAÇÃO PARA ATENDER AOS REQUISITOS DO PRODUTO IMPOSTOS PELO FORNECEDOR

ACESSO À TECNOLOGIA 
OUTROS

\section{4." A MAIORIA DAS AÇÕES DE PARCERIAS E/OU COOPERAÇÃO DESENVOLVIDA POR PELOS PRODUTORES QUE ESTA ENTIDADE TEM CONTACTO, SURGIU...."}

ATRAVÉS DE LAÇOS FAMILIARES.

CONVÍVIO COM OUTROS MEMBROS DESTA ENTIDADE E/OU ASSOCIAÇÃO DE PRODUTORES.

COMUNIDADE ÉTNICA DA QUAL SÃO DESCENDENTES

CONSOLIDAÇÃO DAS RELAÇÕES COMERCIAIS, COM O TEMPO

PELO INCENTIVO/INTERMEDIAÇÃO DO SINDICATO PATRONAL, E/OU SINDICATO DE TRABALHADORES; ENTIDADES COMO SEBRAE, SENAR, ASSOCIAÇÃO COMERCIAL LOCAL; ETC.

INDEPENDENTEMENTE DE LAÇOS CULTURAIS E/OU DE ASCENDÊNCIA ESTRANGEIRA, FORAM ESTABELECIDAS TAIS AÇÕES POR QUE SEI DA IMPORTÂNCIA DELAS PARA O FORTALECIMENTO DA ESTRUTURA DE PRODUÇÃO E/OU COMERCIALIZAÇÃO DA QUAL DEPENDEM SEUS ASSOCIADOS.

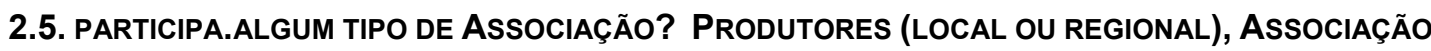
COMERCIAL LOCAL OU ASSOCIAÇÕES LOCAIS RELACIONADAS A OUTROS FINS, NÃO VOLTADAS AO DESENVOLVIMENTO DE SEUS NEGÓCIOS

2.6. EM CASO AFIRMATIVO DA QUESTÃO ANTERIOR, ESPECIFIQUE QUAIS SERVIÇOS ESTA COOPERATIVA SE UTILIZA DAS ASSOCIAÇÕES DA QUAL É FILIADA E COM QUAL FREQÜÊNCIA

\begin{tabular}{|l|l|l|l|}
\hline \multicolumn{1}{|c|}{ Serviço } & $\begin{array}{c}\text { Nenhuma } \\
\text { freqüência }\end{array}$ & Pouca freqüência & $\begin{array}{c}\text { Muita } \\
\text { freqüência }\end{array}$ \\
\hline Comercialização de produtos & & & \\
\hline Compra de insumos & & & \\
\hline Consorcio de Exportação & & & \\
\hline Participação em feiras e eventos & & & \\
\hline Assessoria jurídica & & & \\
\hline Assessoria administrativa & & & \\
\hline Informações sobre outras Empresas/Cooperativas & & & \\
\hline Informações de mercado & & & \\
\hline Boletins de informação & & & \\
\hline Lobby & & & \\
\hline Capacitação de mão-de-obra & & & \\
\hline Cursos e seminários para o produtor & & & \\
\hline Acesso/conhecimento de novas tecnologias & & & \\
\hline Acesso/conhecimento de linhas de crédito & & \\
\hline Outros (favor especificar) & & & \\
\hline
\end{tabular}

2.7. Caso esta cooperativa a tenha estabelecido parcerias Com outros produtores, CLIENTES, FORNECEDORES OU OUTRAS EMPRESAS QUE ATUEM NO SETOR DE AGRONEGÓCIOS DE FLORES E PLANTASPOR FAVOR, ESPECIFIQUE O(S) MOTIVO(S QUE O LEVARAM A TAL ATITUDE.

Motivos promotores das Ações Conjuntas/ Parcerias

Compartilhar instalações de produção

Compartilhar a utilização de equipamentos de produção, estufas, etc.

Compartilhar instalações de pesquisa

Participação conjunta em feiras (nacionais e/ou internacionais), exposições, etc.

Compartilhar a estrutura de vendas (canais, propaganda, marca, etc.)

Compras conjuntas de insumos e equipamentos

Participação em consórcios de exportação

Compartilhamento de idéias e informações (técnicas, organizacionais, etc), novidades

tecnológicas,

Desenvolvimento ou melhoria de insumos, produtos ou processos de produção

Treinamento de pessoal - cursos - dia de campo

Capacitação para atender aos requisitos do produto impostos pelo cliente

Capacitação para atender aos requisitos do produto impostos pelo fornecedor

Acesso à tecnologia

Outros (favor especificar): 


\section{BLOCO 3- LOCALIDADE}

EM TERMOS GERAIS, QUAL É A REGIÃO DE MAIS IMPORTANTE PARA OS AGRONEGÓCIOS DE FLORES E PLANTAS No Estado de São Paulo: Holambra, Mogi das CRUZEs, Atibaia ou Registro?

O MUNICÍPIO (REGIÃO) DE HOLAMBRA/MOGI DAS CRUZES POSSIBILITA MELHORES CONDIÇÕES PARA O DESEMPENHO DOS NEGÓCIOS DE FLORES, SE COMPARADO À OUTROS MUNICÍPIOS E/OU REGIÕES DO BRASIL

A GERAÇÃO DE CONHECIMENTO REFERENTE A TECNOLOGIA DE PRODUÇÃO E COMERCIALIZAÇÃO DE FLORES E PLANTAS É UM DOS PRINCIPAIS FATORES DE SUCESSO PARA A OS AGRONEGÓCIOS DE FLORES E PLANTAS ORNAMENTAIS? ESSA GERAÇÃO ESTÁ CONCENTRRADA PRIORITARIAMENTE CONCENTRADA NO MUNICIPIO DE HOLAMBRA E REGIÃO?

O MUNICÍPIO DE HOLAMBRA E REGIÃO É A ÁREA MAIS IMPORTANTE DOS AGRONEGÓCIOS DE PLANTAS E FLORES DO BRASIL, NO TOCANTE AO PROCESSO DE COMERCIALIZAÇÃO

AONDE SE CONCENTRA PRIORIRATRIAMENTE A GERAÇÃO DE CONHECIMENTO E TECNOLOGIA RELACIONADA AOS AGRONEGÓCIOS DE FLORES E PLANTAS NO BRASIL? ESTÁ CONCENTRADA NOS CENTROS DE PESQSUISA AGROPECUÁRIOS, COMO EMBRAPA E IAC OU ESTÁ CONCENTRADA NAS EMPRESAS PRIVADAS DE INSUMOS E MAQUINÁRIOS?

O GOVERNO LOCAL É ATUANTE NO SENTIDO DE PROMOVER O DESENVOLVIMENTO DOS AGRONEGÓCIOS DE FLORES NA REGIÃO?

OS RESULTADOS DE DESEMPENHO DE NEGÓCIOS DE SEUS ASSOCIADOS SÃO SUPERIORES AQUELES QUE PODERIAM SER OBSERVADOS SE ESTIVESSEM LOCALIZADOS EM OUTRA REGIÃO?

QUAIS AS PRINCIPAIS VANTAGENS QUE A LOCALIZAÇÃO DE SEUS ASSOCIADOS NO MUNICÍPIO DE HOLAMBRA E REGIÃO QUE ESTA COOPERATIVA PODE IDENTIFICAR?

Melhor acesso à matéria-prima, infra-estrutura e assistência técnica

Possibilidade de criar parcerias

Maior acesso ao mercado consumidor

Aproximação com outros produtores possibilitando desenvolvimento de novos produtos e/ou novas técnicas de produção

Disponibilidade de mão-de-obra e treinamento

Apoio de entidades, associações de classe, SENAR, SEBRAE, associação comercial, etc.

Dificulta a entrada de novos atores que não tenham nenhum vínculo com a localidade, devido a dificuldade de aceitação dos mesmos por parte do grupo de atores local

Facilita a comercialização e distribuição dos produtos

Ser beneficiado por estar inserido num pólo de excelência na produção e comercialização de flores e plantas

Nestes municípios é que se concentram os melhores especialistas e infra-estrutura em comercialização e produção de flores do país

O FORTE TRAÇO ÉTNICO-CULTURAL, POR EXEMPLO ORIENTAIS OU HOLANDESES (OU SEUS DESCENDENTES) FACILITA MUITO O DESENVOLVIMENTO PARCERIAS E AUMENTA A CONFIANÇA MÚTUA.

ESTE MUNICIPIO/REGIÃO PODE SER CONSIDERADO COMO UM PÓLO DE EXCELÊNCIA EM CULTIVO PROTEGIDO?

QUAIS AS PRINCIPAIS DESVANTAGENS QUE A LOCALIZAÇÃO DE SEUS COOPERADOS NESTE MUNICÍPIO/NESTA REGIÃO QUE

ESTA COOPERATIVA PODE IDENTIFICAR?

Contribui para a saturação das possibilidades de produção local

Aumento das rivalidades e conflitos entre os concorrentes

Pressiona os custos com infra-estrutura para cima

Pressiona os salários para cima

Problemas de circulação - trânsito

Acelera ao desgaste da infra-estrutura local

Acaba por atrair produtores de outras regiões, principalmente para a comercialização de seus produtos, e isso vai deteriorando as fortes relações entre os produtores locais Dificuldades em distribuir os produtos pela saturação dos distribuidores locais Outras 
COM RELAÇÃO À PERCEPÇÃO DE COMO OS PROFISSIONAIS DOS AGRONEGÓCIOS, RECONHECEM ESTE MUNICÍPO E REGIÃO. PODEMOS AFIRMAR QUE TAL RECONHECIMENTO SE DÁ...

pela produção/ comércio de flores

pelos agronegócios em geral

pelo turismo relacionado a flores e as tradições culturais

pela fruticultura

pela cultura de hortaliças

devido a produção animal (suinocultura, aves de postura e/ou corte)

pela excelência tecnológica em cultivo protegido (estufa)

Por outros motivos ( por favor, especifique)

\section{BLOCO 4 - INOVAÇÃO/INFORMAÇÕES}

4.1. IDENTIFIQUE A(S) FONTE(S) DE INFORMAÇÃO (ÕES) MAIS IMPORTATES, PARA GERAR NOVOS CONHECIMENTOS PARA O DESENVOLVIMENTO DOS NEGÓCIOS DESTA

\section{FONTE}

Conversas informais

Entidades de apoio (SEBRAE, SENAR, centros de tecnologia)

Fornecedor de maquinário

Feiras e eventos similares

Dia de Campo

Entidades de classe (sindicatos, associações comerciais, e etc.)

Publicações especializadas

Visitas a outras empresas e/ou propriedades da região

Clientes

Vendedores

Empresas do exterior que tenho contato freqüente
Visitas a empresas e/ou propriedades de fora da região

Funcionários que trabalharam em outras empresas ou propriedades

Consultores especializados da região

Consultores especializados de outras regiões

Revistas especializadas

Serviços da ASSOCIAÇAO e/ou associação

da qual sou filiado

$\mathrm{Na}$ troca de informações com outros

produtores

Vendedores e técnicos das empresas de

insumo e/ou infra-estrutura

Assistência técnica governamental

Assistência técnica privada

Outras: (especificar, por favor)

\subsection{QUANTO À ORIGEM DAS INOVAÇÕES TECNOLÓGICAS DE SEUS ASSOCIADOS}

\begin{tabular}{|l|l|l|l|l|l|}
\hline & Sempre & $\begin{array}{c}\text { Na maioria } \\
\text { das vezes }\end{array}$ & Raramente & Nunca & Não Sabe \\
\hline $\begin{array}{l}\text { Estão embutidas nas máquinas compradas no } \\
\text { mercado nacional }\end{array}$ & & & & \\
\hline $\begin{array}{l}\text { Estão embutidas nas máquinas compradas no } \\
\text { mercado internacional }\end{array}$ & & & & & \\
\hline $\begin{array}{l}\text { São desenvolvidas internamente nas } \\
\text { propriedades }\end{array}$ & & & & \\
\hline São adaptadas internamente nas propriedades & & & & \\
\hline $\begin{array}{l}\text { São desenvolvidas em cooperação com } \\
\text { fornecedores }\end{array}$ & & & & \\
\hline São geradas por fornecedores estrangeiros & & & & & \\
\hline São geradas por fornecedores domésticos/locais & & & & \\
\hline São geradas por clientes estrangeiros & & & & \\
\hline São geradas por fornecedores locais/domésticos & & & & \\
\hline São desenvolvidas em cooperação com clientes & & & & & \\
\hline $\begin{array}{l}\text { São desenvolvidas em cooperação com outras } \\
\text { empresas locais }\end{array}$ & & & & & \\
\hline Outra Origem especificar) & & & & & \\
\hline
\end{tabular}


4.3. IDENTIFIQUE O(S) FATORE(S) QUE PODE(M) SER RELACIONADO(S) A INOVAÇÃo NO CONTEXTO dos AGRONEGÓCIOS DE FLORES E PLANTAS FONTE

Variedades, cultivares, etc

Técnicas de cultivo

Técnicas de armazenagem

Adaptação de espécies às

coindições locais de cultivo

Desenvolvimento de Máquinas e

Equipamentos

Selos de origem e/ou qualidade

Outros (por favor, especificar)

FONTE

Desenvolvimento de Embalagens para produto

final (flores e plantas)

Veiling

Técnicas de adubação e controle fitossanitário

Comercialização

Processos administrativos da propriedade rural

Marca própria

\section{BLOCO 5-BLOCO 5 - GESTÃO / ESTRATÉGIAS DE}

\subsection{COM RELAÇÃO VISÃO GERAL DOS AGRONEGÓCIOS DE FLORES NO ESTADO DE SÃO PAULO}

O MERCADO NACIONAL DE FLORES E PLANTAS É UMA OPORTUNIDADE CRESCENTE DE NEGÓCIO PARA OS PRODUTORES DE FLORES E PLANTAS

O MERCADO INTERNACIONAL DE FLORES E PLANTAS É UMA OPORTUNIDADE CRESCENTE DE NEGÓCIO PARA OS PRODUTORES BRASILEIROS

A PRESENÇA DE UM AGENTE COORDENADOR NA CADEIA DE PRODUÇÃO E COMERCIALIZAÇÃO DE FLORES E PLANTAS É UM FATOR ESSENCIAL PARA O SUCESSO DESSE TIPO DE NEGÓCIO? ESTE AGENTE DEVE NECESSARIAMENTE SER UM REPRESENTANTE DOS PRODUTORES RURAIS?

A FALTA DE POLÍTICAS PÚBLICAS PARA O SETOR INTERFERE DE FORMA SIGNIFICATIVA E NEGATIVAMENTE NO DESEMPENHO DOS AGRONEGÓCIOS DE FLORES

O DESCONHECIMENTO DE FONTES DE FINANCIAMENTO, POR PARTE DOS PRODUTORES, É UM DOS PRINCIPAIS FATORES QUE PREJUDICAM UM MELHOR DESEMPENHO DOS NEGÓCIOS DE FLORES

A ALTA BUROCRACIA E EXIGÊNCIAS PARA OBTENÇÃO DE FINANCIAMENTOS, É UM DOS PRINCIPAIS FATORES QUE PREJUDICAM UM MELHOR DESEMPENHO DOS NEGÓCIOS DE FLORES

O COOPERATIVISMO E/OU ASSOCIATIVISMO É UM FATOR ESSENCIAL PARA O SUCESSO DOS AGRONEGÓCIOS DE FLORES E PLANTAS ORNAMENTAIS

A IDENTIDADE ÉTNICA E CULTURAL FAVORECE AS RELAÇÕES DE PARCERIAS E O DESENVOLVIMENTO DE ATIVIDADES CONJUNTAS ENTRE OS PRODUTORES E DEMAIS ATORES DA CADEIA DE PRODUÇÃO

A CONCENTRAÇÃO GEOGRÁFICA DE PRODUTORES E DEMAIS ATORES DA CADEIA DE PRODUÇÃO DE FLORES E PLANTAS ORNAMENTAIS É FUNDAMENTAL PARA O SUCESSO DOS NEGÓCIOS

QUANDO NÃO ESTÃO ATRELADOS A NENHUMA COOPERATIVA, ASSOCIAÇÃO OU AGENTE DISTRIBUIDOR, NA GRANDE MAIORIA DAS VEZES O PRODUTOR NÃO TEM CRITÉRIOS PARA ESCOLHA SEGURA DE SEUS CLIENTES,

COM RELAÇÃO A FATORES COMO PREÇO, PRODUTOS INOVADORES QUALIDADE, CONFIANÇA DE SEUS CLIENTES E A ENTREGA RÁPIDA E PONTUAL, EXISTE ALGUM DELES QUE SE SOBREPONHA EM IMPORTÃNCIA PARA ESSE TIPO DE NEGÓCIO?

AS QUESTÕES AMBIENTAIS (LEGISLAÇÃO, OUTORGA D'ÁGUA, ETC.) INTERFEREM DE ALGUMA MANEIRA NESSE TIPO DE NEGÓCIO?

QUAIS OS PRINCIPAIS BENEFICIOS DA PARTICIPAÇÃO EM EVENTOS COMO HORTITEC, ENFLOR, EXPLOFLORA, FESTA DO MORANGO E FLORES OU OUTRO DO MESMO GENERO?

\subsection{CLIENTES}

COM RELAÇAO AO PERFIL DOS PRINCIPAIS CLIENTES DOS PRODUTORES DESTA ASSOCIAÇÃO

são grandes Empresas e/ou produtores

São grandes atacadistas

São grandes supermercados

são pequenas /médias empresas e/ou produtores

SEUS ASSOCIADOS DEPENDEM DRASTICAMENTE DE ALGUNS CLIENTES ESPECÍFICOS

SEUS ASSOCIADOS POSSUEM O MAIOR PODER DE BARGANHA NOS PROCESSOS DE NEGOCIAÇÃO 
AONDE SE ENCONTRAM OS PRINCIPAIS CLIENTES DE SEUS ASSOCIADOS?

\subsection{CONCORRENCIA}

AONDE SE ENCONTRAM OS PRINCIPAIS CONCORRENTES DE SEUS ASSOCIADOS?

COM RELAÇAO AO PERFIL DOS PRINCIPAIS CONCORRENTES DOS PRODUTORES DESTA REGIÃO DE

PODEMOS DIZER QUE

são grandes Empresas que atuam no mesmo ramo

são pequenos e médias empresas que atuam no mesmo ramo

são as cooperativas do município e/ou região, que eles não são associados

Não existe concorrência para seus associados

\subsection{FINANÇAS}

A ASSOCIAÇAO CONHECE ALGUMA FONTE PÚBLICA DE FINANCIAMENTO

A MAIORIA DOS PRODUTORES QUE TEMOS ACESSO FINANCIAM A EXPANSÃO DA CAPACIDADE PRODUTIVA COM capital próprio,

bancos públicos de investimento,

sistema financeiro internacional

investimento da ASSOCIAÇÃO e/ou cooperativas a que são afiliados

outros

5.4. CAso esta AsSOCIAÇÃo PARTICIPE de ALgUM EVENTO COMO HORTITEC, ENFLOR, EXPLOFLORA, FESTA DO MORANGO E FLORES, OU OUTRO DO MESMO GENÊRO, QUAL(IS) OS MOTIVOS QUE A LEVARAM A TAL PARTICIPAÇÃO?

FACILITA A APROXIMAÇÃO COM OS CLIENTES

ESTE TIPO DE EVENTO TRAZ A POSSIBILIDADE DE CRIAR PARCERIAS E COOPERAÇÃO ATRAVÉS DA MAIOR APROXIMAÇÃO COM OUTRAS EMPRESAS

ESTE TIPO DE EVENTO TRAZ PROMOVE MAIOR ACESSO AO MERCADO CONSUMIDOR

ESTE TIPO DE EVENTO PROMOVE A ABERTURA DE NOVOS NEGÓCIOS

ESTE TIPO DE EVENTO TRAZ A POSSIBILIDADE PARA CONHECIMENTO DO QUE ESTÁ SENDO OFERECIDO PELA CONCORRÊNCIA

ESTE TIPO DE EVENTO FACILITA A DIFUSÃO DA MARCA E/OU PRODUTO

ESTE TIPO DE EVENTO FAVORECE O CONHECIMENTO DAS NECESSIDADES DOS CLIENTES

OUTRO. (ESPECIFICAR) 


\section{ROTEIRO DE ENTREVISTAS - EMPRESAS MEIO}

BLOCO 1- CARACTERIZAÇÃO

\subsection{DADOS DO RESPONDENTE}

NOME:

CARGO / FUNÇÃO NA COOPERATIVA

TELEFONE PARA CONTATO:

E-MAIL:

\subsection{A EMPRESA}

\subsubsection{DADOS GERAIS}

\section{EMPRESA:}

MUNICIPIO:

PORTE (GRANDE, MÉDIO OU PEQUENO):

RAMO (PRODUTO/SERVIÇO):

NOME DO RESPONDENTE

CARGO / FUNÇÃO:

TELEFONE PARA CONTATO:

E-MAIL:

1.2.3. ASSinALE EM QUAL DOS SEgmENTOS ABAIXO QUE ESTA COOERATIVA ATUA.

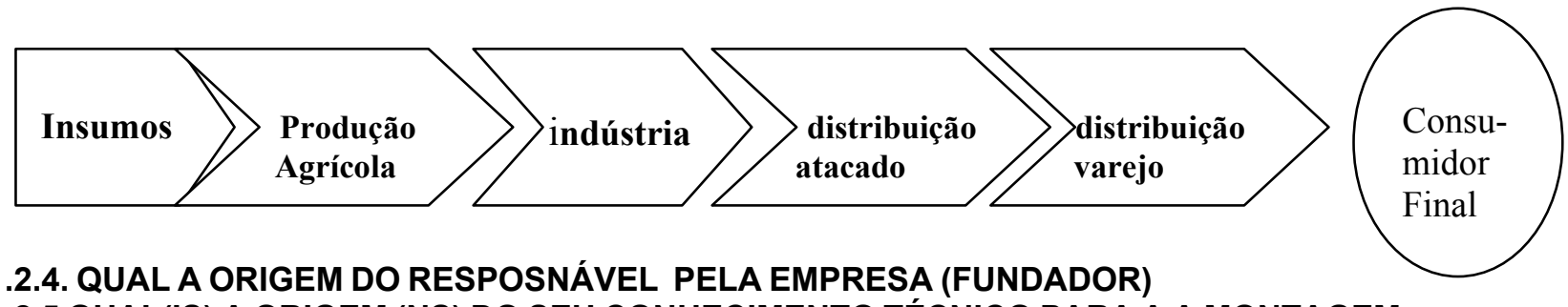

1.2.4. QUAL A ORIGEM DO RESPOSNÁVEL PELA EMPRESA (FUNDADOR)

1.2.5 QUAL(IS) A ORIGEM (NS) DO SEU CONHECIMENTO TÉCNICO PARA A A MONTAGEM DESSA EMPRESA?

1.2.5. ANTES DE INICIAR SEU PRÓPRIO NEGÓCIO, O RESPONSÁVEL PELA EMPRESA TRABALHAVA COMO EMPREGADO EM OUTRA ATUANTE NO MESMO RAMO OU EM RAMO SIMILAR ?

\section{BLOCO 2-COOPERAÇÃO/PARCERIA}

2.1 Estabeleceu AÇÕES DE COOPERAÇÃo E/OU PARCERIAS COM OUTROS PROdUTORES, FORNECEDORES, CLIENTES E/OU OUTRAS EMPRESAS QUE ATUAM EM SUA MESMA ÁREA DE NEGÓCIOS?

2.2. QUAIS OS PRINCIPAIS MOTIVOS DAS AÇÕES DE PARCERIA QUE FORAM DESENVOLVIDAS PELOS SES ASSOCIADOS E COM QUAL FREQUENCIA? 


\begin{tabular}{|l|l|l|l|l|}
\hline \multicolumn{2}{|c|}{ Cooperação/Parceria } & \multicolumn{3}{c|}{ FREQÜÉNCIA } \\
\cline { 2 - 5 } & Nenhuma & Alta & Mediana & Baixa \\
\hline $\begin{array}{l}\text { Outros produtores rurais que cultivam as } \\
\text { mesmas espécies que são cultivadas em sua } \\
\text { propriedade }\end{array}$ & & & & \\
\hline $\begin{array}{l}\text { Outros produtores rurais que cultivam as } \\
\text { outras espécies que são cultivadas em sua } \\
\text { propriedade }\end{array}$ & & & & \\
\hline Clientes situados no Brasil & & & & \\
\hline Clientes situados no Exterior & & & & \\
\hline SEBRAE & & & & \\
\hline SENAR & & & & \\
\hline Entidades de pesquisa (IAC, EMBRAPA, etc.) & & & & \\
\hline Casa da Agricultura-CATI & & & & \\
\hline Esta associação não tem essa informação & & & & \\
\hline Outros (favor especificar) & & & & \\
\hline
\end{tabular}

2.3. CASO ESTA ENTIDADE TENHA IDENTIFICADO ALGUM TIPO DE PARCERIA NA QUESTÃO ANTERIOR, POR FAVOR, QUAIS OS PRINCIPAIS MOTIVO QUE LEVARAM SEUS ASSOCIADOS A DESENVOLVEREM TAIS AÇÕES DE COOPERAÇÃO OU PARCERIA.

COMPARTILHAR INSTALAÇÕES DE PRODUÇÃO

COMPARTILHAR A UTILIZAÇÃO DE EQUIPAMENTOS DE PRODUÇÃO, ESTUFAS, ETC.

COMPARTILHAR INSTALAÇÕES DE PESQUISA

PARTICIPAÇÃO CONJUNTA EM FEIRAS (NACIONAIS E/OU INTERNACIONAIS), EXPOSIÇÕES, ETC.

COMPARTILHAR A ESTRUTURA DE VENDAS (CANAIS, PROPAGANDA, MARCA, ETC.)

COMPRAS CONJUNTAS DE INSUMOS E EQUIPAMENTOS

PARTICIPAÇÃO EM CONSÓRCIOS DE EXPORTAÇÃO

COMPARTILHAMENTO DE IDÉIAS E INFORMAÇÕES (TÉCNICAS, ORGANIZACIONAIS, ETC), NOVIDADES TECNOLÓGICAS,

DESENVOLVIMENTO OU MELHORIA DE INSUMOS, PRODUTOS OU PROCESSOS DE PRODUÇÃO

TREINAMENTO DE PESSOAL - CURSOS - DIA DE CAMPO

CAPACITAÇÃO PARA ATENDER AOS REQUISITOS DO PRODUTO IMPOSTOS PELO CLIENTE

CAPACITAÇÃO PARA ATENDER AOS REQUISITOS DO PRODUTO IMPOSTOS PELO FORNECEDOR

ACESSO À TECNOLOGIA

OUTROS

\section{4." A MAIORIA DAS AÇÕES DE PARCERIAS E/OU COOPERAÇÃO DESENVOLVIDA POR PELOS PRODUTORES QUE ESTA ENTIDADE TEM CONTACTO, SURGIU....”}

ATRAVÉS DE LAÇOS FAMILIARES.

CONVÍVIO COM OUTROS MEMBROS DESTA ENTIDADE E/OU ASSOCIAÇÃO DE PRODUTORES.

COMUNIDADE ÉTNICA DA QUAL SÃO DESCENDENTES

CONSOLIDAÇÃO DAS RELAÇÕES COMERCIAIS, COM O TEMPO

PELO INCENTIVO/INTERMEDIAÇÃO DO SINDICATO PATRONAL, E/OU SINDICATO DE TRABALHADORES; ENTIDADES COMO SEBRAE, SENAR, ASSOCIAÇÃO COMERCIAL LOCAL; ETC.

INDEPENDENTEMENTE DE LAÇOS CULTURAIS E/OU DE ASCENDÊNCIA ESTRANGEIRA, FORAM ESTABELECIDAS TAIS AÇÕES POR QUE SEI DA IMPORTÂNCIA DELAS PARA O FORTALECIMENTO DA ESTRUTURA DE PRODUÇÃO E/OU COMERCIALIZAÇÃO DA QUAL DEPENDEM SEUS ASSOCIADOS.

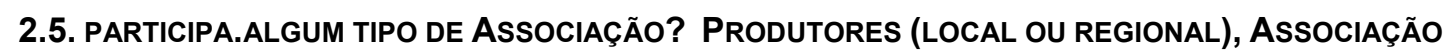
COMERCIAL LOCAL OU ASSOCIAÇÕES LOCAIS RELACIONADAS A OUTROS FINS, NÃO VOLTADAS AO DESENVOLVIMENTO DE SEUS NEGÓCIOS 
2.6. EM CASO AFIRMATIVO DA QUESTÃO ANTERIOR, ESPECIFIQUE QUAIS SERVIÇOS ESTA COOPERATIVA SE UTILIZA DAS ASSOCIAÇÕES DA QUAL É FILIADA E COM QUAL FREQÜÊNCIA

\begin{tabular}{|l|l|l|l|}
\hline \multicolumn{1}{|c|}{ Serviço } & $\begin{array}{c}\text { Nenhuma } \\
\text { freqüência }\end{array}$ & Pouca freqüência & $\begin{array}{c}\text { Muita } \\
\text { freqüência }\end{array}$ \\
\hline Comercialização de produtos & & & \\
\hline Compra de insumos & & & \\
\hline Consorcio de Exportação & & & \\
\hline Participação em feiras e eventos & & & \\
\hline Assessoria jurídica & & & \\
\hline Assessoria administrativa & & & \\
\hline Informações sobre outras Empresas/Cooperativas & & & \\
\hline Informações de mercado & & & \\
\hline Boletins de informação & & & \\
\hline Lobby & & & \\
\hline Capacitação de mão-de-obra & & & \\
\hline Cursos e seminários para o produtor & & & \\
\hline Acesso/conhecimento de novas tecnologias & & & \\
\hline Acesso/conhecimento de linhas de crédito & & \\
\hline Outros (favor especificar) & & \\
\hline
\end{tabular}

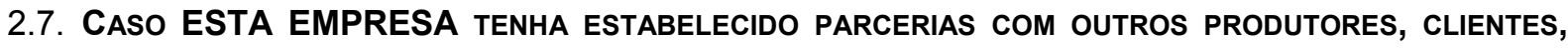 FORNECEDORES OU OUTRAS EMPRESAS QUE ATUEM NO SETOR DE AGRONEGÓCIOS DE FLORES E PLANTASPOR FAVOR, ESPECIFIQUE O(S) MOTIVO(S QUE O LEVARAM A TAL ATITUDE.}

\section{Motivos promotores das Ações Conjuntas/ Parcerias}

Compartilhar instalações de produção

Compartilhar a utilização de equipamentos de produção, estufas, etc.

Compartilhar instalações de pesquisa

Participação conjunta em feiras (nacionais e/ou internacionais), exposições, etc.

Compartilhar a estrutura de vendas (canais, propaganda, marca, etc.)

Compras conjuntas de insumos e equipamentos

Participação em consórcios de exportação

Compartilhamento de idéias e informações (técnicas, organizacionais, etc), novidades tecnológicas,

Desenvolvimento ou melhoria de insumos, produtos ou processos de produção

Treinamento de pessoal - cursos - dia de campo

Capacitação para atender aos requisitos do produto impostos pelo cliente

Capacitação para atender aos requisitos do produto impostos pelo fornecedor

Acesso à tecnologia

Outros (favor especificar):

2.8 A IDENTIDADE ÉTNICA E CULTURAL FAVORECE AS RELAÇÕES DE PARCERIAS E O DESENVOLVIMENTO DE ATIVIDADES CONJUNTAS ENTRE OS PRODUTORES E DEMAIS ATORES DA CADEIA DE PRODUÇÃO

\section{BLOCO 3- LOCALIDADE}

EM TERMOS GERAIS, QUAL É A REGIÃO DE MAIS IMPORTANTE PARA OS AGRONEGÓCIOS DE FLORES E PLANTAS No Estado de SÃo Paulo: Holambra, Mogi das CRUZES, Atibaia ou Registro?

O MUNICÍPIO (REGIÃO) DE HOLAMBRA/MOGI DAS CRUZES POSSIBILITA MELHORES CONDIÇÕES PARA O DESEMPENHO DOS NEGÓCIOS DE FLORES, SE COMPARADO À OUTROS MUNICÍPIOS E/OU REGIÕES DO BRASIL

A GERAÇÃO DE CONHECIMENTO REFERENTE A TECNOLOGIA DE PRODUÇÃO E COMERCIALIZAÇÃO DE FLORES E PLANTAS É UM DOS PRINCIPAIS FATORES DE SUCESSO PARA A OS AGRONEGÓCIOS DE FLORES E PLANTAS ORNAMENTAIS? ESSA GERAÇÃO ESTÁ CONCENTRRADA PRIORITARIAMENTE CONCENTRADA NO MUNICIPIO DE HOLAMBRA E REGIÃO?

O MUNICIPIO DE HOLAMBRA E REGIÃO É A ÁREA MAIS IMPORTANTE DOS AGRONEGÓCIOS DE PLANTAS E FLORES DO BRASIL, NO TOCANTE AO PROCESSO DE COMERCIALIZAÇÃO

AONDE SE CONCENTRA PRIORIRATRIAMENTE A GERAÇÃO DE CONHECIMENTO E TECNOLOGIA RELACIONADA AOS AGRONEGÓCIOS DE FLORES E PLANTAS NO BRASIL? ESTÁ CONCENTRADA NOS CENTROS DE PESQSUISA 
AGROPECUÁRIOS, COMO EMBRAPA E IAC OU ESTÁ CONCENTRADA NAS EMPRESAS PRIVADAS DE INSUMOS E MAQUINÁRIOS?

O GOVERNO LOCAL É ATUANTE NO SENTIDO DE PROMOVER O DESENVOLVIMENTO DOS AGRONEGÓCIOS DE FLORES NA REGIÃO?

OS RESULTADOS DE DESEMPENHO DE NEGÓCIOS DE SEUS ASSOCIADOS SÃO SUPERIORES AQUELES QUE PODERIAM SER OBSERVADOS SE ESTIVESSEM LOCALIZADOS EM OUTRA REGIÃO?

QUAIS AS PRINCIPAIS VANTAGENS QUE A LOCALIZAÇÃO DE SEUS ASSOCIADOS NO MUNICÍPIO DE HOLAMBRA E REGIÃO QUE ESTA EMPRESA PODE IDENTIFICAR?

Melhor acesso à matéria-prima, infra-estrutura e assistência técnica

Possibilidade de criar parcerias

Maior acesso ao mercado consumidor

Aproximação com outros produtores possibilitando desenvolvimento de novos produtos e/ou novas técnicas de produção

Disponibilidade de mão-de-obra e treinamento

Apoio de entidades, associações de classe, SENAR, SEBRAE, associação comercial, etc.

Dificulta a entrada de novos atores que não tenham nenhum vínculo com a localidade, devido a dificuldade de aceitação dos mesmos por parte do grupo de atores local Facilita a comercialização e distribuição dos produtos

Ser beneficiado por estar inserido num pólo de excelência na produção e comercialização de flores e plantas

Nestes municípios é que se concentram os melhores especialistas e infra-estrutura em comercialização e produção de flores do país

O FORTE TRAÇO ÉTNICO-CULTURAL, POR EXEMPLO ORIENTAIS OU HOLANDESES (OU SEUS DESCENDENTES) FACILITA MUITO O DESENVOLVIMENTO PARCERIAS E AUMENTA A CONFIANÇA MÚTUA.

ESTE MUNICIPIO/REGIÃO PODE SER CONSIDERADO COMO UM PÓLO DE EXCELÊNCIA EM CULTIVO PROTEGIDO

QUAIS AS PRINCIPAIS DESVANTAGENS QUE A LOCALIZAÇÃO NESTE MUNICÍPIO/NESTA REGIÃO QUE ESTA

EMPRESA PODE IDENTIFICAR?

Contribui para a saturação das possibilidades de produção local

Aumento das rivalidades e conflitos entre os concorrentes

Pressiona os custos com infra-estrutura para cima

Pressiona os salários para cima

Problemas de circulação - trânsito

Acelera ao desgaste da infra-estrutura local

Acaba por atrair produtores de outras regiões, principalmente para a comercialização de seus produtos, e isso vai deteriorando as fortes relações entre os produtores locais

Dificuldades em distribuir os produtos pela saturação dos distribuidores locais Outras

COM RELAÇÃO À PERCEPÇÃO DE COMO OS PROFISSIONAIS DOS AGRONEGÓCIOS, RECONHECEM ESTE MUNICÍPO E REGIÃO. PODEMOS AFIRMAR QUE TAL RECONHECIMENTO SE DÁ...

pela produção de flores

pelo comércio de flores

pelos agronegócios em geral

pelo turismo relacionado a flores e as tradições culturais

pela fruticultura

pela cultura de hortaliças

devido a produção animal (suinocultura, aves de postura e/ou corte)

pela excelência tecnológica em cultivo protegido (estufa)

Por outros motivos ( por favor, especifique) 


\section{BLOCO 4 - INOVAÇÃO/INFORMAÇÕES}

4.1. IDENTIFIQUE A(S) FONTE(S) DE INFORMAÇÃO (ÕES) MAIS IMPORTATES, PARA GERAR NOVOS CONHECIMENTOS PARA O DESENVOLVIMENTO DOS NEGÓCIOS DESTA EMPRESA

\section{FONTE}

Conversas informais

Entidades de apoio (SEBRAE, SENAR, centros de tecnologia)

Fornecedor de maquinário

Feiras e eventos similares

Dia de Campo

Entidades de classe (sindicatos, associações comerciais, e etc.)

Publicações especializadas

Visitas a outras empresas e/ou propriedades da região

Clientes

Vendedores

Empresas do exterior que tenho contato freqüente

\section{FONTE}

Visitas a empresas e/ou propriedades de fora da região

Funcionários que trabalharam em outras empresas ou propriedades

Consultores especializados da região

Consultores especializados de outras regiões

Revistas especializadas

Serviços da ASSOCIAÇAO e/ou associação

da qual sou filiado

$\mathrm{Na}$ troca de informações com outros

produtores

Vendedores e técnicos das empresas de insumo e/ou infra-estrutura

Assistência técnica governamental

Assistência técnica privada

Outras: (especificar, por favor)

4.2. QUANTO À ORIGEM DAS INOVAÇÕES TECNOLÓGICAS DE SEUS NEGÓCIOS

\begin{tabular}{|l|l|l|l|l|l|}
\hline & Sempre & $\begin{array}{l}\text { Na maioria } \\
\text { das vezes }\end{array}$ & Raramente & Nunca & Não Sabe \\
\hline $\begin{array}{l}\text { Estão embutidas nas máquinas compradas no } \\
\text { mercado nacional }\end{array}$ & & & & & \\
\hline $\begin{array}{l}\text { Estão embutidas nas máquinas compradas no } \\
\text { mercado internacional }\end{array}$ & & & & & \\
\hline $\begin{array}{l}\text { São desenvolvidas internamente nas } \\
\text { propriedades }\end{array}$ & & & & & \\
\hline São adaptadas internamente nas propriedades & & & & & \\
\hline $\begin{array}{l}\text { São desenvolvidas em cooperação com } \\
\text { fornecedores }\end{array}$ & & & & & \\
\hline São geradas por fornecedores estrangeiros & & & & & \\
\hline São geradas por fornecedores domésticos/locais & & & & & \\
\hline São geradas por clientes estrangeiros & & & & & \\
\hline São geradas por fornecedores locais/domésticos & & & & & \\
\hline São desenvolvidas em cooperação com clientes & & & & & \\
\hline $\begin{array}{l}\text { São desenvolvidas em cooperação com outras } \\
\text { empresas locais }\end{array}$ & & & & & \\
\hline Outra Origem especificar) & & & & & \\
\hline
\end{tabular}

4.3. IDENTIFIQUE O(S) FATORE(S) QUE PODE(M) SER RELACIONADO(S) A INOVAÇÃO NO CONTEXTO DOS AGRONEGÓCIOS DE FLORES E PLANTAS

\section{FONTE}

Variedades, cultivares, etc

Técnicas de cultivo

Técnicas de armazenagem

Adaptação de espécies às

coindições locais de cultivo

Desenvolvimento de Máquinas e

Equipamentos

Selos de origem e/ou qualidade

Outros (por favor, especificar)

\section{FONTE}

Desenvolvimento de Embalagens para produto final (flores e plantas)

Veiling

Técnicas de adubação e controle fitossanitário

Comercialização

Processos administrativos da propriedade rural

Marca própria 


\section{BLOCO 5-BLOCO 5- GESTÃO / ESTRATÉGIAS}

\subsection{COM RELAÇÃO VISÃO GERAL DOS AGRONEGÓCIOS DE FLORES NO ESTADO DE SÃO PAULO}

O COOPERATIVISMO E/OU ASSOCIATIVISMO É UM FATOR ESSENCIAL PARA O SUCESSO DOS AGRONEGÓCIOS DE FLORES E PLANTAS ORNAMENTAIS

O DESCONHECIMENTO DE FONTES DE FINANCIAMENTO, POR PARTE DOS PRODUTORES, É UM DOS PRINCIPAIS FATORES QUE PREJUDICAM UM MELHOR DESEMPENHO DOS NEGÓCIOS DE FLORES

A ALTA BUROCRACIA E EXIGÊNCIAS PARA OBTENÇÃO DE FINANCIAMENTOS, É UM DOS PRINCIPAIS FATORES QUE PREJUDICAM UM MELHOR DESEMPENHO DOS NEGÓCIOS DE FLORES

A CONCENTRAÇÃO GEOGRÁFICA DE PRODUTORES E DEMAIS ATORES DA CADEIA DE PRODUÇÃO DE FLORES E PLANTAS ORNAMENTAIS É FUNDAMENTAL PARA O SUCESSO DOS NEGÓCIOS

COM RELAÇÃO A FATORES COMO PREÇO, PRODUTOS INOVADORES QUALIDADE, CONFIANÇA DE SEUS CLIENTES E A ENTREGA RÁPIDA E PONTUAL, EXISTE ALGUM DELES QUE SE SOBREPONHA EM IMPORTÃNCIA PARA ESSE TIPO DE NEGÓCIO?

QUAIS OS PRINCIPAIS BENEFICIOS DA PARTICIPAÇÃO EM EVENTOS COMO HORTITEC, ENFLOR, EXPLOFLORA, FESTA DAS FLORES OU OUTRO DO MESMO GENERO?

\subsection{CLIENTES}

SEUS PRINCIPAIS CLIENTES

são grandes Empresas e/ou produtores

São grandes atacadistas

São grandes supermercados

são pequenas /médias empresas e/ou produtores

DEPENDEM DRASTICAMENTE DE ALGUNS CLIENTES ESPECÍFICOS

POSSUEM O MAIOR PODER DE BARGANHA NOS PROCESSOS DE NEGOCIAÇÃO

AONDE SE ENCONTRAM LOCALIZADOS OS SEUS PRINCIPAIS CLIENTES?

\subsection{FORNECEDORES}

SUA EMPRESA DEPENDE DRASTICAMENTE DE ALGUNS FORNECEDORES SEUS PRINCIPAIS FORNECEDORES SÃO PEQUENAS/MÉDIAS EMPRESAS

SEUS FORNECEDORES PRINCIPAIS, POSSUEM O MAIOR PODER DE BARGANHA NAS NEGOCIAÇÕES AONDE SE ENCONTRAM LOCALIZADOS SEUS PRINCIPAIS FORNECEDORES ?

\subsection{CONCORRENCIA}

AONDE SE ENCONTRAM OS PRINCIPAIS CONCORRENTES DE SEUS ASSOCIADOS?

COM RELAÇAO AO PERFIL DOS PRINCIPAIS CONCORRENTES DOS PRODUTORES DESTA REGIÃO DE PODEMOS DIZER QUE

são grandes Empresas que atuam no mesmo ramo

são pequenos e médias empresas que atuam no mesmo ramo

são as cooperativas do município e/ou região, que eles não são associados

Não existe concorrência para seus associados

Seus principais concorrentes são grandes Empresas que atuam no mesmo ramo

Seus principais concorrentes são pequenos e médias empresas que atuam no mesmo ramo

Seus principais concorrentes estão localizados na região de Mogi das Cruzes/Holambra

Seus principais concorrentes estão localizados em outro Estado

Seus principais concorrentes se acham distribuídos em diversas regiões

Seus principais concorrentes estão localizados no exterior

Não conhece seus concorrentes

\subsection{FINANÇAS}

A EMPRESA CONHECE ALGUMA FONTE PÚBLICA DE FINANCIAMENTO

FINANCIA A EXPANSÃO DA CAPACIDADE PRODUTIVA COM

capital próprio,

bancos públicos de investimento,

sistema financeiro internacional

outros 
ANEXO B

QUESTIONÁRIOS-PESQUISA QUANTITATIVA 
BLOCO 1- CARACTERIZAÇÃo

\subsection{Dados Gerais do Respondente}

Nome:

Telefone para Contato:

E-mail:

\subsection{Perfil da Propriedade}

Município:

\begin{tabular}{|l|l|l}
\hline Percentagem & (aproximada) da área com floricultura: & Ano de inicio na floricultura:
\end{tabular}

1.3. O RESPONSÁVEL PELA PRODUÇÃo DE FLORES NESTA PROPRIEDADE É:

a) ( ) Holandês ou descendente de holandês

b) ( ) Japonês ou descendente de japonês

c) ( ) Brasileiro sem vinculo de ascendência holandesa ou japonesa

d) ( ) Outra origem (favor especificar);

1.4. O SEU CONHECIMENTO TÉCNICO PARA A PRODUÇÃO DE FLORES/PLANTAS VEM:

a) ( ) Da tradição familiar

b) ( ) Do convívio com produtores da localidade

c) ( ) Do estudo e desenvolvimento próprio

d) ( ) Aprendizado em propriedade que trabalhava como empregado

e) ( ) De outra origem (favor especificar);

1.5. ASSINALE O PRINCIPAL MEIO DE COMERCILIZAÇÃO DE SEUS PRODUTOS
a ( ) Cooperativa
b ( ) Ceasa Local
c ( ) Atacadista, varejista ou vendedor independente
d ( ) Direto Para o consumidor Final
e ( ) Outros (favor especificar)

2.4 IDENTIFIQUE A(S)) FONTE(S) DE INFORMAÇÃo (ÕES) MAIS IMPORTATES, EM SEU ENTENDIMENTO, PARA GERAR NOVOS CONHECIMENTOS PARA O DESENVOLVIMENTO DE SEUS NEGÓCIOS. PARA TANTO, POR FAVOR, ASSINALE NA COLUNA A DIREITA DE CADA FONTE QUE JULGAR RELEVANTE.

\begin{tabular}{|l|l|l|l|}
\hline \multicolumn{1}{|c|}{ FONTE } & \multicolumn{1}{|c|}{ FONTE } & $\begin{array}{l}\text { Visitas a empresas e/ou propriedades de fora da } \\
\text { região }\end{array}$ & \\
\hline Conversas informais & $\begin{array}{l}\text { Funcionários que trabalharam em outras empresas } \\
\text { propriedades }\end{array}$ & \\
\hline Vendedores & & Consultores especializados da região & \\
\hline Fornecedor de maquinário & & Consultores especializados de outras regiões & Revistas especializadas \\
\hline Feiras e eventos similares & & $\begin{array}{l}\text { Serviços da cooperativa e/ou associação da qual } \\
\text { sou filiado }\end{array}$ & \\
\hline Dia de Campo & & Na troca de informações com outros produtores \\
\hline Clientes & & $\begin{array}{l}\text { Vendedores e técnicos das empresas de insumo } \\
\text { e/ou infra-estrutura }\end{array}$ & \\
\hline Publicações especializadas & & Assistência técnica governamental & \\
\hline $\begin{array}{l}\text { Visitas a outras empresas e/ou propriedades da } \\
\text { região }\end{array}$ & & Assistência técnica privada & \\
\hline $\begin{array}{l}\text { Entidades de classe (sindicatos, associações } \\
\text { comerciais) }\end{array}$ & & Outras: (especificar, por favor) \\
\hline $\begin{array}{l}\text { Entidades de apoio (SEBRAE, SENAR, centros } \\
\text { de tecnologia) }\end{array}$ & & \\
\hline $\begin{array}{l}\text { Empresas do Exterior que tenho contato } \\
\text { freqüente }\end{array}$ & & \\
\hline
\end{tabular}

\subsection{A PARA CADA UMA DAS FRASES ABAIXO, POR FAVOR ASSINALE A COLUNA QUE MELHOR REPRESENTE} SUA OPINIÃO. 


\begin{tabular}{|c|c|c|c|c|c|}
\hline & DiscoRDo & INDIFERENTE & $\begin{array}{l}\text { NÃO } \\
\text { TENHO } \\
\text { OPINIÃO } \\
\text { OU NÃO } \\
\text { SEI }\end{array}$ & $\begin{array}{l}\text { CONCORDO } \\
\text { PARCIAL } \\
\text { MENTE }\end{array}$ & CONCORDO \\
\hline $\begin{array}{l}\text { A maior parte (ou a totalidade) de sua } \\
\text { produção é feita em cultivo protegido }\end{array}$ & & & & & \\
\hline $\begin{array}{l}\text { O NUMERO DE ESPÉCIES QUE PODE CULTIVAR É } \\
\text { DEFINIDA PELO SR., EM FUNÇÃO DE SUA } \\
\text { CAPACIDADE DE PRODUÇÃO ASSOCIADO A } \\
\text { DEMANDA DO MERCADO }\end{array}$ & & & & & \\
\hline
\end{tabular}

\section{BLOCO 2 - COOPERAÇÃO}

2.1.As AÇÕES DE COOPERAÇÃo E/OU PARCERIAS COM OUTROS PRODUTORES, FORNECEDORES, CLIENTES E/OU OUTRAS EMPRESAS QUE ATUAM NUMA MESMA ÁREA DE NEGÓCIOS, PODEM SER COMUNS. COM RELAÇÃO A ESTE TIPO DE AÇÃO, POR FAVOR ASSINALE A FREQÜÊNCIA COM QUE ESSAS SÃo DESENVOLVIDAS EM SEUS NEGÓCIOS.

\begin{tabular}{|l|l|l|l|l|}
\hline \multicolumn{2}{|c|}{ Cooperação/Parceria } & \multicolumn{3}{c|}{ FREQÜÊNCIA } \\
\cline { 2 - 5 } & Nenhuma & Alta & Mediana & Baixa \\
\hline $\begin{array}{l}\text { Outros produtores rurais que cultivam as mesmas } \\
\text { espécies que são cultivadas em sua propriedade }\end{array}$ & & & & \\
\hline $\begin{array}{l}\text { Outros produtores rurais que cultivam as outras } \\
\text { espécies que são cultivadas em sua propriedade }\end{array}$ & & & & \\
\hline Fornecedores situados no Exterior & & & & \\
\hline Fornecedores situados no Brasil & & & & \\
\hline Clientes situados no Brasil & & & & \\
\hline Clientes situados no Exterior & & & & \\
\hline SEBRAE & & & & \\
\hline SENAR & & & & \\
\hline Entidades de pesquisa (IAC, EMBRAPA, etc.) & & & & \\
\hline Casa da Agricultura-CATI & & & & \\
\hline Outros (favor especificar & & & & \\
\hline
\end{tabular}


.2. Caso tenha estabelecido algum tipo de parceria e/OU AÇÃo CONJUNTA IDENTIFICADA ACIMA, POR FAVOR, ASSINALE PARA CADA UM DOS COMPLEMENTOS DA FRASE EM DESTAQUE (ÁREA SOMBREADA), A COLUNA QUE CORRESPONDE AO SEU GRAU DE CONCORDÂNCIA.

\begin{tabular}{|c|c|c|c|c|c|}
\hline $\begin{array}{c}\text { "A maioria das ações de parcerias } \\
\text { e/ou cooperação com outros } \\
\text { produtores, clientes, fornecedores } \\
\text { ou outras empresas da floricultura } \\
\text { que estabeleci surgiu ..." }\end{array}$ & DISCORDO & INDIFERENTE & $\begin{array}{l}\text { NÃO TENHO } \\
\text { OPINIÃO OU } \\
\text { NÃO SEI }\end{array}$ & $\begin{array}{l}\text { CONCORDO } \\
\text { PARCIAL - } \\
\text { MENTE }\end{array}$ & CONCORDO \\
\hline através de laços familiares. & & & & & \\
\hline $\begin{array}{l}\text { convívio com outros produtores da } \\
\text { cooperativa e/ou associação de } \\
\text { produtores que pertenço. }\end{array}$ & & & & & \\
\hline $\begin{array}{l}\text { Comunidade étnica da qual sou } \\
\text { descendente }\end{array}$ & & & & & \\
\hline $\begin{array}{l}\text { consolidação das relações comerciais, } \\
\text { com o tempo }\end{array}$ & & & & & \\
\hline $\begin{array}{l}\text { pelo incentivo/intermediação da } \\
\text { cooperativa e/ou associação de } \\
\text { produtores a qual sou filiado }\end{array}$ & & & & & \\
\hline $\begin{array}{l}\text { pelo incentivo/intermediação do } \\
\text { Sindicato Patronal, e/ou Sindicato de } \\
\text { trabalhadores; entidades como } \\
\text { SEBRAE, SENAR, associação } \\
\text { comercial local; etc. }\end{array}$ & & & & & \\
\hline $\begin{array}{l}\text { independentemente de laços culturais } \\
\text { e/ou de ascendência estrangeira, } \\
\text { estabeleci tais ações por que sei da } \\
\text { importância delas para o } \\
\text { fortalecimento da estrutura de } \\
\text { produção e/ou comercialização da } \\
\text { qual dependo. }\end{array}$ & & & & & \\
\hline
\end{tabular}

2.3. CASO A TENHA ESTABELECIDO PARCERIAS COM OUTROS PRODUTORES, CLIENTES, FORNECEDORES OU OUTRAS EMPRESAS QUE ATUEM NO SETOR DE AGRONEGÓCIOS DE FLORES E PLANTASPOR FAVOR, ASSINALE O(S) MOTIVO(S QUE O LEVARAM A TAL ATITUDE.

\begin{tabular}{|l|l|}
\hline \multicolumn{1}{|c|}{ Motivos promotores das Ações Conjuntas/ Parcerias } & \\
\hline Compartilhar instalações de produção & \\
\hline Compartilhar a utilização de equipamentos de produção, estufas, etc. & \\
\hline Compartilhar instalações de pesquisa & \\
\hline Participação conjunta em feiras (nacionais e/ou internacionais), exposições, etc. & \\
\hline Compartilhar a estrutura de vendas (canais, propaganda, marca, etc.) & \\
\hline Compras conjuntas de insumos e equipamentos & \\
\hline Participação em consórcios de exportação & \\
\hline $\begin{array}{l}\text { Compartilhamento de idéias e informações (técnicas, organizacionais, etc), novidades } \\
\text { tecnológicas, }\end{array}$ & \\
\hline Desenvolvimento ou melhoria de insumos, produtos ou processos de produção & \\
\hline Treinamento de pessoal - cursos - dia de campo & \\
\hline Capacitação para atender aos requisitos do produto impostos pelo cliente & \\
\hline Capacitação para atender aos requisitos do produto impostos pelo fornecedor & \\
\hline Acesso à tecnologia & \\
\hline Outros (favor especificar): & \\
\hline
\end{tabular}


2.4 A PARA CADA UMA DAS FRASES ABAIXO, POR FAVOR ASSINALE A COLUNA QUE MELHOR REPRESENTE SUA OPINIÃO.

\begin{tabular}{|c|c|c|c|c|c|}
\hline & DISCORDO & INDIFERENTE & $\begin{array}{c}\text { NÃO } \\
\text { TENHO } \\
\text { OPINIÃO } \\
\text { OU NÃO } \\
\text { SEI }\end{array}$ & $\begin{array}{c}\text { CONCORDO } \\
\text { PARCIAL } \\
\text { MENTE }\end{array}$ & CONCORDO \\
\hline $\begin{array}{l}\text { O Sr mantém contato freqüente com técnicos } \\
\text { da CATI e/ou casa da agricultura, }\end{array}$ & & & & & \\
\hline $\begin{array}{l}\text { O Sr recebe freqüentes informações por parte } \\
\text { da(s) cooperativa(s), SEBRAE, SENAR, } \\
\text { associação comercial, associação de } \\
\text { produtores da qual sou associado, sobre linhas } \\
\text { de financiamento de meus negócios e formas } \\
\text { de gestão }\end{array}$ & & & & & \\
\hline
\end{tabular}


Bloco 3 - Localidade

3.1. Para cada uma das frases abaixo, assinale a coluna que melhor represente sua opinião.

\begin{tabular}{|c|c|c|c|c|c|}
\hline & DIscoRDO & $\begin{array}{l}\text { INDIF } \\
\text { EREN } \\
\text { TE }\end{array}$ & $\begin{array}{l}\text { NÃO } \\
\text { TENHO } \\
\text { OPINIÃO } \\
\text { OU NÃOO } \\
\text { SEI }\end{array}$ & $\begin{array}{l}\text { CONCORD } \\
\text { O PARCIAL } \\
\text {-MENTE }\end{array}$ & CONCORDO \\
\hline \multicolumn{6}{|l|}{$\begin{array}{l}\text { O governo local é atuante no sentido de promover o } \\
\text { desenvolvimento dos agronegócios de flores no } \\
\text { município e/ou região }\end{array}$} \\
\hline \multicolumn{6}{|l|}{$\begin{array}{l}\text { A cooperativa/associação é atuante no sentido de } \\
\text { promover o desenvolvimento dos agronegócios de } \\
\text { flores e plantas para seus associados }\end{array}$} \\
\hline \multicolumn{6}{|l|}{$\begin{array}{l}\text { Não conheço nenhum tipo de política pública } \\
\text { relacionada a promoção do desenvolvimento dos } \\
\text { agronegocios de flores e plantas nesta região }\end{array}$} \\
\hline \multicolumn{6}{|l|}{$\begin{array}{l}\text { O município (região) onde desenvolvo meus negócios } \\
\text { apresenta as melhores condições para o } \\
\text { desempenho da floricultura, se comparado à outros } \\
\text { municípios e/ou regiões do Brasil. }\end{array}$} \\
\hline \multicolumn{6}{|l|}{$\begin{array}{l}\text { Esta Região onde estou sediado é reconhecida } \\
\text { especificamente pela produção de flores e plantas. }\end{array}$} \\
\hline \multicolumn{6}{|l|}{$\begin{array}{l}\text { Esta Região onde estou sediado é reconhecida pela } \\
\text { comercialização de flores. }\end{array}$} \\
\hline \multicolumn{6}{|l|}{$\begin{array}{l}\text { Esta Região onde estou sediado é reconhecida pelo } \\
\text { cultivo protegido }\end{array}$} \\
\hline \multicolumn{6}{|l|}{$\begin{array}{l}\text { Uma das vantagens em estar localizado neste } \\
\text { município de HOLAMBR/MOGI DAS CRUZES e/ou } \\
\text { região é rima, infra-estrutura e assistência técnica }\end{array}$} \\
\hline \multicolumn{6}{|l|}{$\begin{array}{l}\text { Uma das vantagens em estar localizado neste } \\
\text { município região de HOLAMBR/MOGI DAS } \\
\text { CRUZES A e/ou é que facilita a contratação de mão- } \\
\text { de-obra especializada no cultivo de flores e } \\
\text { treinamento. }\end{array}$} \\
\hline \multicolumn{6}{|l|}{$\begin{array}{l}\text { Uma das vantagens em estar localizado neste } \\
\text { município de HOLAMBR/MOGI DAS CRUZES A } \\
\text { e/ou região é que me proporciona a aproximação } \\
\text { com outros produtores de flores, o que ajuda na } \\
\text { solução de problemas relacionados ao meu negócio } \\
\text { (produção e venda) }\end{array}$} \\
\hline \multicolumn{6}{|l|}{$\begin{array}{l}\text { Uma das desvantagens em estar localizado neste } \\
\text { município (região) que existe uma saturação das } \\
\text { possibilidades de produção local, pois atrai } \\
\text { produtores de outras regiões. }\end{array}$} \\
\hline \multicolumn{6}{|l|}{$\begin{array}{l}\text { Uma das desvantagens em estar localizado neste } \\
\text { município de HOLAMBR/MOGI DAS CRUZES e/ou } \\
\text { região que a localidade está sofrendo com o atração } \\
\text { de novos produtores, que está deteriorando as fortes } \\
\text { relações entre os produtores locais mais antigos. }\end{array}$} \\
\hline $\begin{array}{l}\text { Uma das desvantagens em estar localizado neste } \\
\text { município de HOLAMBR/MOGI DAS CRUZES e/ou } \\
\text { região é que a alta concentração de produtores e de } \\
\text { outros agentes de negócios aqui, pressiona os custos } \\
\text { de produção para cima. }\end{array}$ & & & & & \\
\hline
\end{tabular}


Bloco 4 - Cooperativismo/Associativismo

4.1.. ESPECIFIQUE QUAL (OU QUAIS) COOPERATIVA(S) DAS QUAIS PARTICIPA
a) $($ )
Não sou associado a nenhuma cooperativa
b) ( )
Pertenço a(s) seguinte(s) cooperativa(s):

4.2,Assinale a(s) ASSOCIAÇões(s) Da(s) QUAL(IS) PARTICIPA.

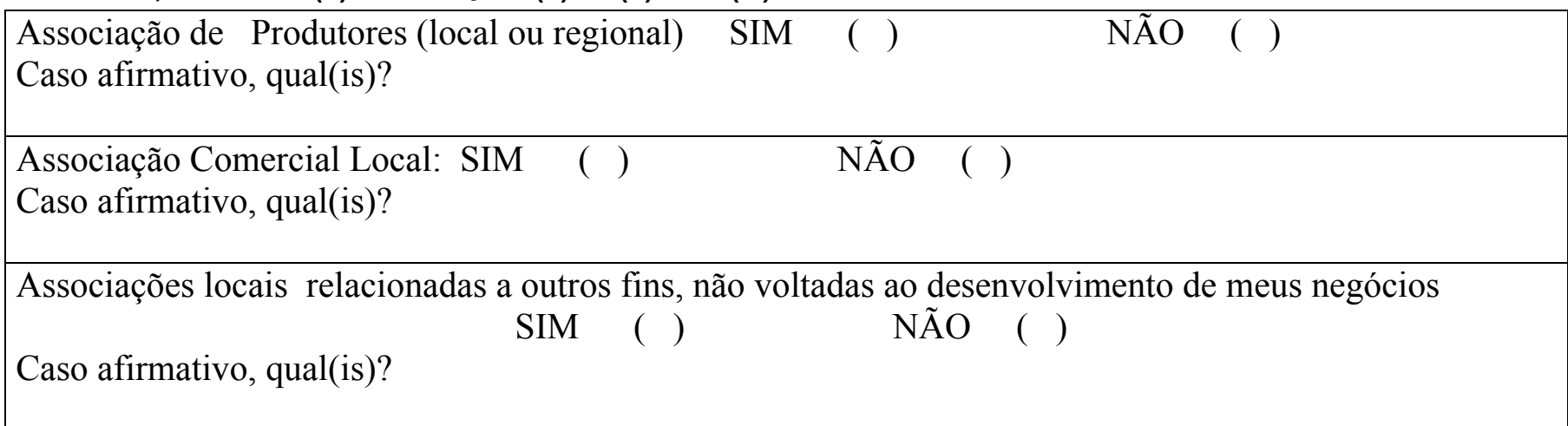

4.3. CASO O SR. SEJA ASSOCIADO A ALGUMA COOPERATIVA OU ASSOCIAÇÃo dE PROdUTORES LOCAIS, PARA CADA UMA DAS FRASES ABAIXO, ASSINALE A COLUNA QUE MELHOR REPRESENTE SUA OPINIÃO

\begin{tabular}{|l|l|l|l|l|l|}
\hline & DISCORDo & INDIFERENTE & $\begin{array}{c}\text { NÃO TENHO } \\
\text { OPINIÃO OU } \\
\text { NÃO SEI }\end{array}$ & $\begin{array}{c}\text { CONCORDO } \\
\text { PARCIAL - } \\
\text { MENTE }\end{array}$ & CONCORDO \\
\hline $\begin{array}{l}\text { O numero de espécies que o Sr. pode } \\
\text { cultivar é definida pela cooperativa ou } \\
\text { associação a que pertence }\end{array}$ & & & & \\
\hline $\begin{array}{l}\text { A maior parte (ou a totalidade) de sua } \\
\text { produção vai para a cooperativa ou } \\
\text { associação de produtores que participo }\end{array}$ & & & & & \\
\hline $\begin{array}{l}\text { A cooperativa distribui e comercializa seus } \\
\text { produtos de maneira mais eficiente do que } \\
\text { se não estivesse me associando a ela }\end{array}$ & & & & & \\
\hline $\begin{array}{l}\text { A associação a que pertence apesar de } \\
\text { não atuar diretamente na comercialização } \\
\text { dos seus produtos, auxilia bastante nessa } \\
\text { etapa }\end{array}$ & & & & & \\
\hline $\begin{array}{l}\text { A cooperativa/associação estabelece os } \\
\text { preços de venda e as condições para } \\
\text { recebimento das vendas de seus produtos }\end{array}$ & & & & & \\
\hline $\begin{array}{l}\text { A cooperativa/associação estreita os laços } \\
\text { de relacionamento e confiança entre os } \\
\text { produtores }\end{array}$ & & & & & \\
\hline $\begin{array}{l}\text { A cooperativa/associação promove com } \\
\text { freqüência o treinamento/ capacitação dos } \\
\text { produtores e/ou seus empregados }\end{array}$ & & & & & \\
\hline $\begin{array}{l}\text { A cooperativa/associação divulga com } \\
\text { freqüência os agentes e as linhas de } \\
\text { financiamentos disponiveis. }\end{array}$ & & & & & \\
\hline $\begin{array}{l}\text { O cooperativismo e/ou associativismo é } \\
\text { fundamental para o bom desempenho de } \\
\text { meus negócios flores e plantas) nesta } \\
\text { região }\end{array}$ & & & & & \\
\hline
\end{tabular}

